\title{
CONTESTANDOAS
}

\section{- EDITORA}

FRONTEIRASDE

GÊMERO, RAÇAE

SEXUALIDADENA

SOCIEDADEBRASILEIRA

ORGANIIZADORES

Fabrício de Sousa Sampaio LeonardoPereira Tavares

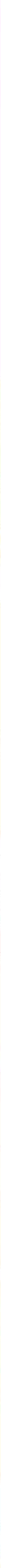




\section{CONTESTANDOAS}

\section{$7^{\text {EDTORAA }}$}

FRONTEIRASDE

GÊMERO, RAÇAE

SEXUALIDADENA

SOCIEDADE BRASILEIRA

ORGANIZADORES

Fabricio de Sousa Sampaio Leonardo Pereira Tavares

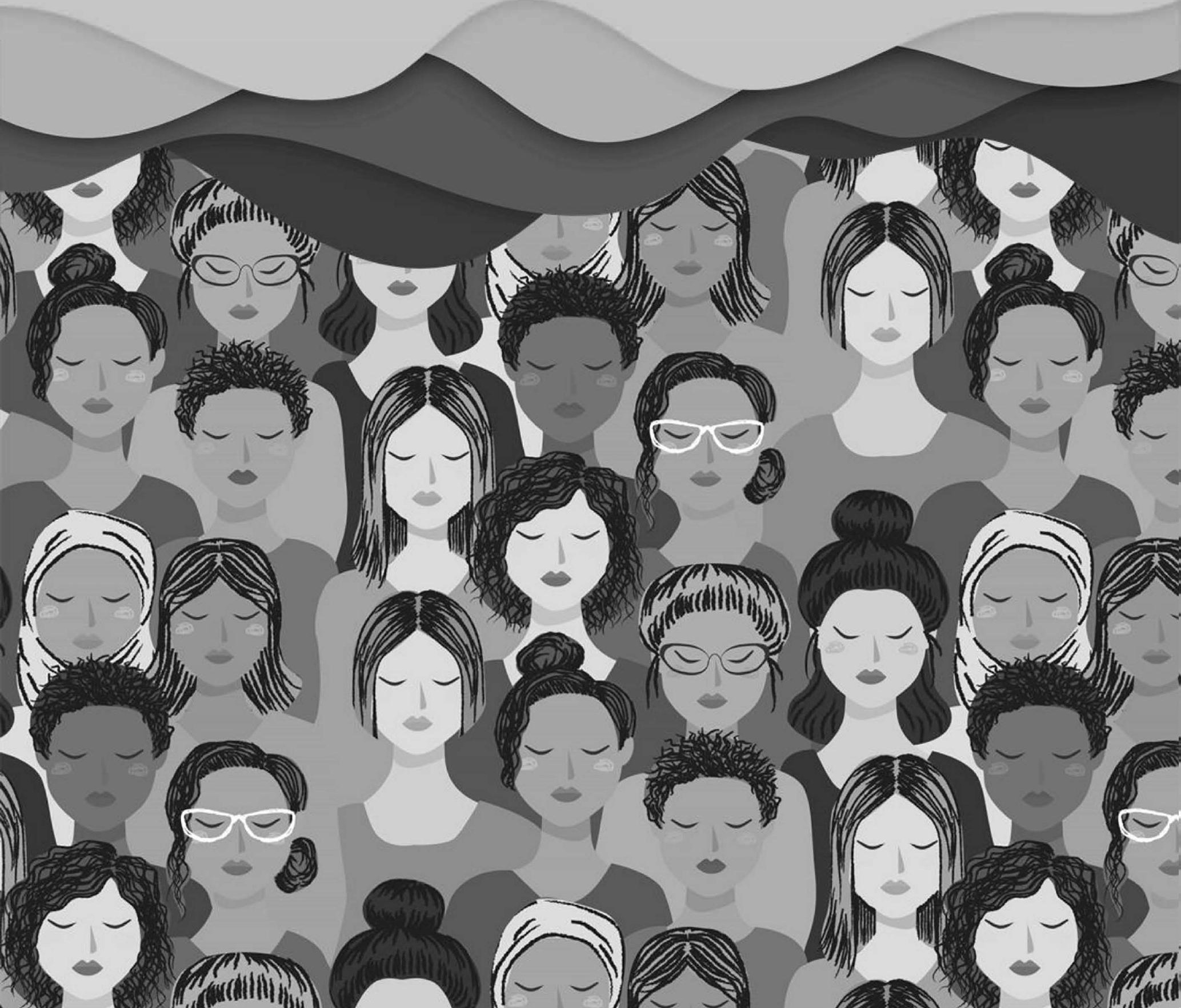




\section{ZIMAPLLA}

2020 - Editora Amplla

Copyright @ Editora Amplla

Editor Chefe: Leonardo Pereira Tavares

Design da Capa: Editora Amplla

Projeto Gráfico e Editoração: Higor Costa de Brito

Contestando as fronteiras de gênero, raça e sexualidade na sociedade brasileira está licenciado sob CC BY 4.0.

Esta licença exige que as reutilizações deem crédito ao criador. Ele permite que os reutilizadores distribuam, remixem, adaptem e construam o material em qualquer meio ou formato, mesmo para fins comerciais.

O conteúdo da obra e seus dados em sua forma, correção e confiabilidade são de responsabilidade exclusiva dos autores, não representando a posição oficial da Editora Amplla. É permitido o download da obra e o compartilhamento desde que sejam atribuídos créditos aos autores. Todos os direitos para esta edição foram cedidos à Editora Amplla.

ISBN: 978-65-88332-11-5

Editora Amplla

Campina Grande - PB - Brasil contato@ampllaeditora.com.br www.ampllaeditora.com.br 
Bergson Rodrigo Siqueira de Melo - Universidade Estadual do Ceará Carla Caroline Alves Carvalho - Universidade Federal de Campina Grande Cícero Batista do Nascimento Filho - Universidade Federal do Ceará Clécio Danilo Dias da Silva - Universidade Federal do Rio Grande do Norte Daniela de Freitas Lima - Universidade Federal de Campina Grande Denise Barguil Nepomuceno - Universidade Federal de Minas Gerais Dylan Ávila Alves - Instituto Federal Goiano Érica Rios de Carvalho - Universidade Católica do Salvador Gilberto de Melo Junior - Universidade Federal de Goiás Higor Costa de Brito - Universidade Federal de Campina Grande Italan Carneiro Bezerra - Instituto Federal da Paraíba Ivo Batista Conde - Universidade Estadual do Ceará João Henriques de Sousa Júnior - Universidade Federal de Santa Catarina Joilson Silva de Sousa - Instituto Federal do Rio Grande do Norte José Cândido Rodrigues Neto - Universidade Estadual da Paraíba Jose Henrique de Lacerda Furtado - Instituto Federal do Rio de Janeiro Josenita Luiz da Silva - Faculdade Frassinetti do Recife Luís Paulo Souza e Souza - Universidade Federal do Amazonas Luiza Catarina Sobreira de Souza - Faculdade de Ciências Humanas do Sertão Central Manoel Mariano Neto da Silva - Universidade Federal de Campina Grande Marcus Vinicius Peralva Santos - Universidade Federal da Bahia Marina Magalhães de Morais - Universidade Federal de Campina Grande Natan Galves Santana - Universidade Paranaense Nathalia Bezerra da Silva Ferreira - Universidade do Estado do Rio Grande do Norte Neide Kazue Sakugawa Shinohara - Universidade Federal Rural de Pernambuco Sabrynna Brito Oliveira - Universidade Federal de Minas Gerais Samuel Miranda Mattos - Universidade Estadual do Ceará Tatiana Paschoalette Rodrigues Bachur - Universidade Estadual do Ceará Telma Regina Stroparo - Universidade Estadual do Centro-Oeste Virginia Tomaz Machado - Faculdade Santa Maria de Cajazeiras Walmir Fernandes Pereira - Miami University of Science and Technology Wanessa Dunga de Assis - Universidade Federal de Campina Grande Wellington Alves Silva - Universidade Estadual de Roraima Yáscara Maia Araújo de Brito - Universidade Federal de Campina Grande Yuciara Barbosa Costa Ferreira - Universidade Federal de Campina Grande 
2020 - Editora Amplla

Copyright (C) Editora Amplla

Editor Chefe: Leonardo Pereira Tavares

Design da Capa: Editora Amplla

Projeto Gráfico e Editoração: Higor Costa de Brito

Dados Internacionais de Catalogação na Publicação (CIP)

Sueli Costa CRB-8/5213

Sampaio, Fabrício de Sousa

Contestando as fronteiras de gênero, raça e sexualidade na sociedade brasileira [livro eletrônico] / Fabrício de Sousa Sampaio; Leonardo Pereira Tavares. Campina Grande : Editora Amplla, 2020.

$285 \mathrm{p}$.

Formato: PDF

ISBN : $978-65-88332-11-5$

1. Identidade de gênero 2. Raça 3. Sexualidade I. Tavares, Leonardo Pereira II. Título

$\mathrm{CDD}-306.76$

\section{Índice para catálogo sistemático:}

1. Orientação sexual 306.76

\section{Editora Amplla}

Campina Grande - PB - Brasil contato@ampllaeditora.com.br www.ampllaeditora.com.br 


\section{PREFÁCIO}

Geralmente, a sociedade desigual brasileira é considerada racista, classista, homofóbica, machista e sexista, ou melhor, heterossexista. Estes predicados sociais, além de outros que podem ser citados, são frequentemente confirmados pelos altos índices de violência que se reproduzem cotidianamente nos mais diversos espaços de sociabilidade e vitimizam determinados corpos banidos historicamente para a inferiorização, coisificação ou para o status de semi-humanidade. Em especial, corpos pretos, trabalhadore(a)s pobres e dissidentes da heteronormatividade parecem (re) existir em um cenário que regularmente precariza as condições materiais de suas persistências.

Este livro fala de gênero, sexualidade e raça de maneira interseccional. Sublinha os diferentes processos socioculturais em que estes marcadores são acionados e entrecruzados para possibilitar ou inviabilizar a persistência dos corpos humanos em determinados contextos socioculturais tais como a escola, o convívio familiar, os presídios e as mídias digitais.

No cenário social contemporâneo, especialmente brasileiro, observamos uma movimentação de grupos conservadores ${ }^{1}$, notadamente de fundamentalistas religiosos e/ou neofascistas, que buscam produzir uma desqualificação e/ou pânico social em relação às discussões de gênero e sexualidade, fundamentalmente nos espaços escolares. Neste contexto, a categoria analítica gênero é acusada como articuladora de um processo de destruição da ordem social vigente marcada pela desigualdade de gênero e sexual que se expressa principalmente nas violências perpetradas contra todas as dissidências da heteronormatividade. Assim, tratar da sexualidade dos corpos humanos, principalmente nas escolas, representaria uma estratégia de grupos sociais "contra a família" e "contra Deus" para homossexualizar as crianças e os adolescentes.

A concepção de gênero e de sexualidade acionada por estes grupos é comumente denominada de essencialista na literatura especializada. Gênero e

1 Referência a reação ultraconservadora denominada "ideologia de gênero". Para maiores esclarecimentos, sugiro a leitura: JUNQUEIRA, Rogério Diniz. A invenção da "ideologia de gênero": a emergência de um cenário político-discursivo e a elaboração de uma retórica reacionária antigênero. Revista de Psicologia Política, São Paulo, v. 18, n. 43, p. 449-502, dez. 2018 . Disponível em $<$ http://pepsic.bvsalud.org/scielo.php?script=sci_arttext\&pid=S1519549X2018000300004\&Ing=pt\&nrm=iso>. Acesso em 12 set. 2020. 
sexualidade são interpretados como marcas expressivas dos corpos humanos essencialmente definidos pela existência de dois sexos opostos. A filósofa Judith Butler (2010) em sua obra Problemas de gênero: feminismo e subversão da identidade, desconstrói essas concepções essencialistas utilizando os conceitos de "gênero inteligível" e "matriz heterossexual".

Para Butler, as normas de gênero exigiria o enquadramento dos sujeitos em dois percursos subjetivos oposicionais: de um lado, os corpos biologicamente machos deveriam assumir uma performance masculina padrão e desejarem sexual e afetivamente as mulheres; e de outro, os corpos biologicamente fêmeas, deveriam assumir uma performance feminina universal e desejarem sexual e afetivamente os homens. Nestes esquemas de inteligibilidade binária dos sujeitos, a heterossexualidade seria a única sexualidade possível, universal, aceitável e saudável. Quanto mais os corpos escapassem, por algum momento, destes percursos, mais seriam alvos de políticas culturais de opressão, adaptação, controle ou eliminação: homofobia e Igbtfobia, feminicídio, misoginia, efeminofobia e machismo.

Ao tratarmos destas políticas de mitigação dos escapes corporais da heteronorma, o marcador raça potencializa ou até mesmo lidera as violências que tais políticas sociais produzem. Uma mulher preta lésbica, por exemplo, representaria uma corporalidade mais vulnerável no Brasil do que uma lésbica branca.

A utilização da categoria interssecionalidade permite compreender estas políticas fundamentadas por um entrecruzamento de marcadores sociais - por exemplo, gênero, sexualidade, etnia, raça, classe social, nacionalidade, geração e religiosidade que atuam para maximizar a opressão e a violência a determinados "corpos-alvo".

Esta obra se movimenta em uma perspectiva construtivista e desconstrutivista de gênero e concebe a sexualidade para além de sua dimensão normativa que impossibilita a existência e o reconhecimento das possibilidades e materializações sexuais diferentes. Ela também identifica o marcador raça como estruturante das violências e das desigualdades reproduzidas socialmente contra os corpos generificados e sexuados. A partir desses elementos constituintes, este livro pode ser considerado como um "livro-resistência", devido aos recentes acontecimentos sociais, no Brasil e no mundo. 
Os primeiros textos deste livro tematizam o racismo, a desigualdade de gênero, a violência doméstica e a resistência dos corpos em determinados espaços de sociabilidade. Em seguida, as normas de gênero e de sexualidade são analisadas em contextos escolares em uma perspectiva da diversidade e do respeito, principalmente para os corpos que sofrem violências múltiplas e não são acolhidos em suas corporalidades dissidentes da heteronorma. A perspectiva desconstrutivista de gênero e da sexualidade é tematizada em artigos que tratam do cinema, visibilidade das pessoas negras e da transexualidade. E, nos últimos capítulos, questões relacionadas aos processos de subjetivação da sexualidade, privação da liberdade, encarceramento, direitos humanos e a resistência dos movimentos sociais, retomam a problematização das contestações normativas da intersecção entre gênero, sexualidade e raça.

Este livro objetiva discutir as principais questões sociais do mundo contemporâneo relacionadas ao gênero, à sexualidade e à raça. E, desta maneira, se encaixa em um processo persistente de resistir, em qualquer lugar de fala possível, aos dispositivos sociais que normalizam e até celebram, rotineiramente, as desigualdades, as opressões e as violências contra estes corpos dissidentes pretos, femininos e LGBTQIA+.

Fabrício de Sousa Sampaio Professor EBTT de Sociologia (IFMA/Campus Araioses). Doutor em Ciências Sociais (UFRN). 


\section{SUMÁRIO}

CAPÍtULO I - GÊNERO: DA CATEGORIA dE ANÁLISE À "IDEOLOGIA"

CAPÍTULO II - “E AI SERÁ QUE EXISTE RACISMO NO MEIO GAY?": CONSIDERAÇÕES SOBRE SEXUALIDADE E RAÇA NAS MÍDIAS DIGITAS. 27

CAPÍTULO III - ATOS DE RESISTÊNCIA: ESTRATÉGIAS DE LUTA DAS MULHERES ESCRAVIZADAS E O PESO DO SEXISMO NO FINAL DO SÉCULO XIX EM SANTA CATARINA 41 CAPÍTULO IV - VIOLÊNCIA DOMÉSTICA: UM ESTUDO ACERCA DA VIOLÊNCIA VIVIDA NA INTIMIDADE DO ESPAÇO PRIVADO . .55

CAPÍTULO V - A ESCOLA COMO ESPAÇO OPRESSOR: EXCLUSÕES E VIOLÊNCIAS VIVENCIADAS POR ESTUDANTES LGBT NO AMBIENTE ESCOLAR. 74

CAPÍtULO VI - SEXUALIDADE NOS ESPAÇOS ESCOLARES: UMA ABORdAGEM CRítICA dO ATUAL CENÁ́RIO EDUCACIONAL.

CAPÍTULO VII - A PERCEPÇÃO dE GÊNERO POR ADOLECENTES: VIVÊNCIAS EM UMA ESCOLA PÚBLICA DO OESTE POTIGUAR 111

CAPÍTULO VIII - REPRESENTATIVIDADE FEMININA NO CENÁRIO ACADÊMICO: ESTUDO SOBRE A PARTICIPAÇ̃̃O DAS MULHERES EGRESSAS DO CURSO DE COMUNICAÇÃO SOCIAL DA UFCG .118

CAPÍTULO IX - TRANSFORMANDO A PRÁtICA: CONVERSANDO SOBRE DIVERSIDADE DE GÊNERO E SEXUAL .133

CAPÍTULO X - DIÁLOGO FAMILIAR E SEXUALIDADE NA ADOLESCÊNCIA: CONTRIBUIÇ̄̃ES PARA A CONSTRUÇÃO DO EMPODERAMENTO FEMININO

CAPÍTULO XI - DIREITO À IDENTIDADE, PERSONALIDADE E DIGNIDADE DAS PESSOAS TRANSEXUAIS NO BRASIL - NOME E SEXO/GÊNERO COMO DIREITOS CONSTITUCIONAIS E CIVIS . .164

CAPÍtULO XII - CINEMA QUEER? UMA ANÁLISE DAS OBRAS "FAVELA GAY" (2014) E "DE GRAVATA E UNHA VERMELHA" (2015)

CAPÍTULO XIII - CINEMA, GÊNERO E SEXUALIDADE: A PRODUÇÃO DE (IN)VISIBILIDADES EM "A GLÓRIA E A GRAÇA" (2016) 191 
CAPÍTULO XV - GARANTIA DA DIGNIDADE HUMANA PARA A POPULAÇÃO LGBTQIA+ EM PRIVAÇÃo DE LIBERDADE NO

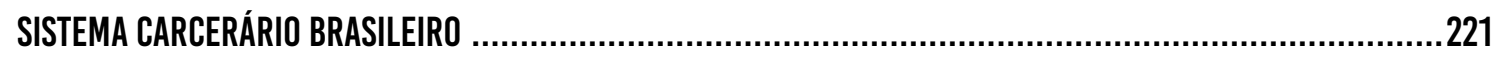

CAPíTULO XVI - “LIBERDADE CAÇA JEITO": UMA PERSPECTIVA PSICANALÍtICA SOBRE AS NOVAS FORMAS DE

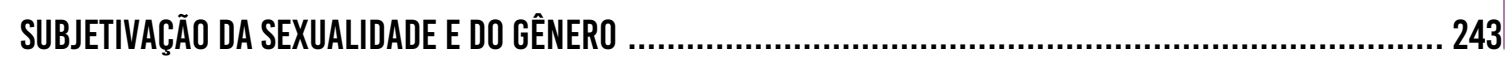

CAPÍTULO XVII - DESIGUALDADE DE CLASSE, RAÇA E GÊNERO, E OS IMPACTOS DO COVID-19 NO BRASIL ........... 262 


\section{CAPÍTULO I}

\section{GÊNERO: DA CATEGORIA DE ANÁLISE À "IDEOLOGIA"}

Fabrício de Sousa Sampaio ${ }^{1}$

1 Professor EBTT de Sociologia - IFMA. Doutor em Ciências Sociais - UFRN.

\section{RESUMO}

A categoria gênero, acionada primeiramente pelo discurso médico para diferenciar sexo biológico e identificação social, já possuía o caráter de construção, ou seja, a identidade de gênero estava ligada aos comportamentos sociais convencionalmente definidos em certa época histórica por determinada cultura em relação ao sexo biológico de cada ser humano. Podemos identificar, inicialmente, pelo menos três grandes perspectivas: a essencialista, a construtivista e a desconstrutivista. Nos últimos anos, nas análises sociais dos processos de desigualdade, opressão e violência, gênero é articulado com outros marcadores sociais para qualificar a compreensão destes processos que são direcionados a determinados corpos humanos dissidentes das normas vigentes ou considerados arbitrariamente inferiores, abjetos ou semi-humanos. Este artigo objetiva identificar as principais perspectivas dos estudos sobre a categoria analítica gênero em contraposição aos sentidos e às intencionalidades políticas da retórica ultraconservadora denominada "ideologia de gênero". A partir de uma revisão bibliográfica, sugerimos compreender a "ideologia de gênero" não apenas como uma reação, marcadamente religiosa, aos avanços analíticos de desnaturalização das normas de gênero, mas sobretudo como uma política de ódio, de desqualificação e apagamento das concepções científicas em favor da sustentação dos essencialismos de gênero e de sexualidade que alicerçam a heteronormatividade.

Palavras-chave: Gênero. Sexualidade. "Ideologia de gênero". Marcadores sociais. Heteronormatividade.

\section{INTRODUÇÃO}

O nascimento é um evento social de ratificação do gênero dos corpos humanos. Desde a comprovação da gravidez até o nascimento, a sociedade aciona um conjunto de normas estabelecidas para determinar os percursos generificados dos novos seres humanos. Por essa razão, Judith Butler reitera que o gênero estabelecido por alguém, com o poder de marcar, se refere às inscrições primárias relacionadas às expectativas dos outros que afetam, inicialmente, os corpos como uma imposição incontrolável e objetivam interiorizar lentamente as normas (BUTLER, 2018, p.37). Nesta situação, 
gênero é uma norma social imposta aos corpos nascentes e que, ao longo de suas existências, poderão subvertê-las ou não.

As reflexões de Butler podem ser consideradas desconstrutivistas. Entretanto, existem inúmeras concepções de gênero as quais são acopladas neste artigo em três perspectivas amplas: essencialista, construtivista e desconstrutivista. Essas definições estão balizadas nos trabalhos de Berenice Bento(2006), Guacira Lopes Louro (2011), Larissa Pelúcio (2014) e Judith Butler (2010). Geralmente, gênero é discutido com as concepções de sexualidade. $E$, recentemente vem sendo analisado, de maneira interseccional, com outros marcados sociais da diferença: raça, etnia, classe social, geração, nacionalidade, entre outros.

Atualmente, observamos a proliferação da "teoria/ideologia de gênero", como catalisador discursivo de "movimentos antigênero" ${ }^{1}$, que buscam desqualificar o campo constituído dos estudos de gênero, bem como sua complexidade e pluralidade. Este sintagma ou neologismo é uma invenção católica que surge em meados dos anos 1990 com o objetivo de reduzir este campo à palavra 'teoria' no singular e à palavra ideologia. Esta redução dos estudos multifacetados de gênero à ideologia, performada pelos discursos "antigêneros", se propõem, através de uma manobra, combater as críticas e as contestações elaboradas historicamente por estes estudos, aos processos de naturalização das relações sociais de gênero (JUNQUEIRA, 2018).

Neste cenário discursivo e de disputa pelo termo gênero, torna-se crucial recuperar, brevemente, as principais elaborações teóricas do gênero para podermos compreender a manobra discursiva que as mobilizações "antigênero" praticam na contemporaneidade. Assim, de que maneira cada perspectiva conceitua o gênero? $\mathrm{E}$ como estas conceituações são objeto de manobra dos movimentos "antigênero"? Que definição de gênero a "ideologia de gênero" objetiva materializar e quais as suas intencionalidades políticas?

${ }^{1}$ Rogério Diniz Junqueira (2018) utiliza o termo 'antigênero' para se referir a um posicionamento antifeminista, antiperspectiva de gênero e contra o reconhecimento da diversidade sexual e de gênero não apenas na vida social, mas sobretudo na construção e implementação de políticas sociais (JUNQUEIRA, 2018, p.452). 
Este artigo $^{1}$ objetiva explicitar as principais conceituações de gênero para subsidiar a compreensão das intencionalidades políticas da "ideologia de gênero". A partir de uma breve revisão bibliográfica, este texto busca identificar os principais elementos teóricos e conceituais do campo de estudos de gênero combatidos pela retórica ultraconservadora e religiosa da "ideologia de gênero" em sua tentativa de: arrefecer ou barrar a disseminação dos recentes avanços analíticos de desnaturalização das normas de gênero; e de materializar uma política de ódio, de desqualificação e apagamento das concepções científicas em favor da sustentação da heteronormatividade.

\section{REVISÃO BIBLIOGRÁFICA}

Nos tempos presentes, antes de nascermos, as pessoas buscam saber, através de exames médicos, não apenas nosso sexo biológico, mas também nosso gênero. Essa preocupação com a atribuição do gênero também é fundamental na maioria dos casos no que se refere às escolhas de filho (a)s durante o processo de adoção. Geralmente, as pessoas buscam adotar determinado menino ou menina, e não, um ser humano, independentemente de seu gênero. Nesta operação social, sexo e gênero são concebidos como marcas corporais importantes para que o bebê seja valorizado na sociedade.

Depois da confirmação do sexo/gênero, alguns familiares ou responsáveis passam a elaborar planos e projeções sociais para este novo ser humano cujo nascimento se aproxima: determinadas formas de comportamentos, tipos de personalidades, futura profissão, tipos de relacionamentos amorosos e sexuais, por exemplo, são imaginados e selecionados para compor uma espécie de programação de gênero. Importante ressaltar que esta programação é construída a partir do contexto sociocultural em que estão inserido (a)s os pais e/ou as mães destes futuros habitantes da sociedade.

De forma ampliada, gênero se refere aos comportamentos, ações, pensamentos, emoções e desejos socialmente construídos a partir da diferença sexual. Ao longo das

\footnotetext{
${ }^{1}$ Uma versão inicial que trata de algumas ideias discutidas neste texto pode ser encontrada na internet através do sítio: https://cafecomsociologia.com/conceito-de-genero/.
} 
histórias das sociedades e das culturas humanas, a diferença entre os sexos funcionou como uma referência fundamental para a construção de um roteiro de gênero arbitrário para que todos os corpos humanos tivessem que assumir ao longo de suas existências sociais. O sexo biológico referendou e continua referendando um dos principais mecanismos de estruturação social: o gênero ou a identidade de gênero.

Para entender melhor o que significa o conceito de identidade no campo das Ciências Humanas, enfatizamos a definição de Stuart Hall (2007) que localiza a identidade na relação entre as estruturas sociais e a subjetividade das pessoas:

Utilizo o termo 'identidade' para significar o ponto de encontro, o ponto de sutura, entre, por um lado, os discursos e as práticas que tentam nos 'interpelar', nos falar ou nos convocar para que assumamos nossos lugares como os sujeitos sociais de discursos particulares e, por outro lado, os processos que produzem subjetividades, que nos constroem como sujeitos aos quais se pode 'falar'. As identidades são, pois, pontos de apego temporário às posições-de-sujeito que as práticas discursivas constroem para nós (HALL, 2007, p. 111-112).

O conceito de identidade social nos permite compreender que aquilo que somos, pensamos e sentimos e que nos diferencia dos outros - a nossa subjetividade - está relacionada com as exigências sociais específicas as quais estão, de certa maneira, resumidas em identidades, ou seja, em um conjunto padronizado e articulado de comportamentos, formas de pensar e sentir reconhecido socialmente.

Somos constituídos por inúmeras identidades as quais são definidas no terreno da cultura e da história (LOURO, 2003). Ao longo de nossas existências sociais, vamos sendo construídos por identidades de classe, de gênero, sexual, profissional, de raça/etnia e nacionalidade, para ficar em poucos exemplos. Todas essas identidades não são incorporadas de maneira fixa ou imutável, elas sofrem operações pessoais de atração, descarte, rejeição e abandono. Por essa razão, Guacira Lopes Louro destaca que as identidades sociais, e por extensão as identidades sexuais e de gênero, são marcadas pela fragmentação, instabilidade, historicidade e pluralidade.

A noção de gênero foi utilizada pela primeira vez, em 1955, pelo psicólogo infantil John Money como ferramenta clínica e de diagnóstico. Ele desenvolveria esta categoria como parte de um conjunto de técnicas cirúrgicas e utilização de hormônios que objetivavam modificar o corpo de bebês intersexos, preconceituosamente 
chamados de hermafroditas, em um passado recente. É importante destacar que o bebê é considerado intersexo se a medicina não conseguir enquadrá-lo como estritamente masculino ou feminino, quando seus órgãos genitais ou cromossomos forem analisados. Money usou a palavra gênero no sentido de uma identidade que pudesse ser conformada ao corpo humano essencialmente a partir de hormônios e técnicas pedagógicas (PRECIADO, 2018, p. 109-110). Em síntese, Money buscou dar um caráter científico a sua tentativa de acoplar identidade social ao sexo biológico.

Mariza Correa (2004) enfatiza que John Money e o psicanalista Robert Stoller, receberam os créditos da literatura médica e de gênero por terem sido os primeiros a discutirem sobre identidade de gênero. Estes médicos estavam convencidos de que a identidade do ser humano era constituída fundamentalmente pela coincidência entre sexo e gênero. John Money, ao fazer uma leitura prejudicial da célebre frase de Simone de Beauvoir - "ninguém nasce mulher: torna-se mulher" - tentou acertar a biologia com as convenções sociais de gênero (CORREA, 2004).

O que podemos retirar destas afirmações anteriores é a ideia de que a categoria gênero, acionada primeiramente pelo discurso médico para diferenciar sexo biológico e identificação, já possuía o caráter de construção social, ou seja, a identidade de gênero estava ligada aos comportamentos sociais convencionalmente definidos em certa época histórica por determinada cultura em relação ao sexo biológico de cada ser humano.

Este contexto inicial de surgimento do conceito de gênero é marcado pela matriz teórica dos estudos de gênero denominada de essencialista. De acordo com esta matriz, os gêneros - masculino e feminino - são naturalmente determinados pela biologia dos corpos. A genitália seria o definidor absoluto de nossas maneiras de perceber, comportar-se, sentir e desejar (PELÚCIO, 2014, p.99). No interior desta perspectiva, existem apenas dois gêneros opostos que são representados por duas formas biológicas distintas de corpos, representadas por duas formas opostas de genitálias: o macho e a fêmea, ou o homem e a mulher. Todo corpo que se distancie destes gêneros e de suas genitálias opostas precisariam ser ajustados ou readaptados. Essa maneira de entender os gêneros como opostos e naturais foi nomeada pela literatura especializada de binarismo de gênero.

Em contrapartida, a matriz teórica construtivista considera os gêneros como efeitos das relações sociais historicamente determinadas. Ser homem ou ser mulher não 
é definido pelos órgãos genitais correspondentes, e sim, arbitrariamente, pela sociedade em um dado momento histórico. As formas de viver, pensar e sentir próprias e exigidas para cada identidade de gênero são definidas pela sociedade. Assim, esta compreensão de que nossa identidade de gênero é uma marca social sobre nossos corpos também necessitará de pensarmos quem elabora esta identidade e para qual finalidade política. Em síntese, por que a sociedade define o gênero como determinado pelo sexo? E por que a diversidade precisa ser silenciada, violada ou adaptada aos dois padrões de gênero opostos? Por que o masculino é o gênero superior e o feminino é sempre objeto de inferiorização, opressão e violência?

Gênero, então, para além da dimensão social, precisa ser entendido em sua dimensão política e por isso deve ser relacionado a outras marcas de diferenciação social, tais como a raça/etnia, classe social, pertencimento de geração e outras (PELÚCIO, 2014, p. 99-100). Esses questionamentos exemplificam as desnaturalizações que os estudos de gênero no campo das Ciências Sociais e Humanas vêm realizando e oferecendo respostas desde o momento em que o conceito de gênero foi incorporado por esse campo tendo como principais protagonistas, os movimentos feministas. A tentativa de responder estas questões enunciadas no final do paraágrafo anterior também é de crucial importância para entendermos a desigualdade de gênero e a Lgbtfobia, por exemplo.

De forma geral, no campo das Ciências Humanas e Sociais, o conceito de gênero foi incorporado para destacar o caráter social das diferenças sexuais: ser homem ou mulher não depende do sexo biológico, é uma fabricação ou um aprendizado que ocorre em contextos culturais (LOURO, 2011, p. 63). Através do conceito de gênero, estes campos do conhecimento objetivam se afastar de proposições essencialistas e se dirigir para a perspectiva da construção social acentuando, desta maneira, a diversidade dos projetos e das representações sociais sobre mulheres e homens.

A sexualidade frequentemente é acionada ao longo dos diferentes estudos de gênero. Foucault (1979), considerado por Jeffrey Weeks (2010) como um dos teóricos mais influentes da perspectiva construcionista da sexualidade, vai questionar em seus estudos por que a sexualidade passou a ser considerada a nossa "'verdade"' e não apenas algo que possibilite a reprodução humana ou o prazer e o gozo. Para Foucault, a sexualidade é um "dispositivo histórico", ou seja, uma rede que interliga um conjunto 
de instituições e discursos que objetivam controlar e determinar nossa sexualidade. Se a nossa "verdade" mais íntima é a nossa sexualidade, a instauração de um dispositivo para controlar e determinar essa "verdade" será mais bem-sucedido do que qualquer outro mecanismo de regulação de nossos corpos. Não raro, atualmente, as pessoas se preocupam fundamentalmente tanto com a sexualidade dos outros quanto a sua, tomando como referência o dispositivo da sexualidade que, em nossa sociedade, determina como normal a heterossexualidade. A sexualidade, pela via do dispositivo, torna-se crucial para nossa existência porque, neste caso, falar de nossa sexualidade é falar do que "realmente" somos.

Richard Miskolci reitera a importância de questionar e resistir ao reducionismo imposto pelo dispositivo da sexualidade que faz com que as pessoas se compreendam a partir de suas sexualidades. Para este autor, a sexualidade se refere ao afeto, ao desejo e à imagem que os outros têm sobre nós (MISKOLCI, 2017, p. 42).

A transposição do termo gênero do contexto anglo-saxão para outros contextos culturais sofreu processos de disputa, ressignificação e apropriação. No Brasil, este conceito chega ao final dos anos 80 (LOURO, 2003 p.23). E com o objetivo de explicitar as principais conceituações sobre a identidade de gênero, acionamos uma breve descrição histórica elaborada pela socióloga Berenice Bento.

Berenice Bento (2006) sugere, a partir de uma incursão histórico-teórica, três tendências explicativas dos processos de constituição das identidades de gênero. $\mathrm{Na}$ primeira tendência, denominada de universal em sua descrição, Bento destaca como representante típico Simone de Beauvoir, fundamentalmente em sua obra O segundo sexo. Nesta tendência, embora que aponte para a construtividade social do gênero e identifique os interesses políticos no posicionamento da mulher como ser humano inferior, há um reforço da essencialização dos gêneros ao cristalizar a identidade em posições fixas. O gênero daria forma e significado ao corpo-sexo - matéria fixa - gerando assim uma identidade essencializada (BENTO, 2006, p.70- 1). Esta tendência não questiona o essencialismo, ou seja, a identidade de gênero continuaria sendo resultado social do sexo biológico.

A segunda tendência foi denominada pela socióloga de perspectiva relacional cujo trabalho de Joan Scott (1995) foi fundamental. Para essa autora, que utilizará das análises do filósofo Michel Foucault a respeito do poder e do processo de desconstrução 
apresentado pelo filósofo Jacques Derrida, o gênero é um "elemento constitutivo das relações sociais nas diferenças percebidas entre os sexos e uma forma primária de dar significados às relações de poder" (BENTO, 2006, p.76). Nesta tendência, o gênero é construído no interior de relações sociais de poder que se estabelecem tendo como pressuposto as diferenças sexuais. A mulher seria inferior porque representaria um gênero frágil e o homem deveria assumir o controle e a tutela sobre todas as mulheres porque representaria o gênero forte ou mais poderoso. O gênero passa a ser a justificativa para construir relações de poder na sociedade localizando o masculino como polo superior.

Berenice Bento (2006), na sua crítica a esta perspectiva, ressalta que, ao se cristalizar o conceito de gênero no referente binário - homem ou mulher - há um reforço dessa mesma estrutura binária e, desta forma, do discurso das diferenças sexuais. Assim, a distinção entre sexo masculino e sexo feminino, funcionaria como uma base indiscutível sobre a identidade de gênero, uma espécie de pré-discursivo [aquilo que existiria antes da linguagem, ou dos discursos, sobre o qual construiríamos denominações ou nomeações para representar a existência daquilo que estamos nos referindo]. Neste caso, sexo existira antes mesmo da cultura nomeá-lo e, por isso, seria uma base indiscutível para determinar a identidade oposicional do gênero.

Berenice Bento enfatiza que, nestas duas perspectivas - universal e relacional o gênero, a sexualidade e a subjetividade não foram considerados fora do binarismo de gênero. Neste sentido, a autora enfatiza os estudos queer ${ }^{1}$ que revelariam o "heterossexismo" das teorias feministas e destacariam as fissuras nas normas de gênero feitas pelas performances (BENTO, 2006, p.78). Em outras palavras, as teorias queer destacarão de que maneira as perspectivas de gênero não problematizariam a diversidade de gênero e de sexualidade. Além disso, em muitas perspectivas de gênero, a heterossexualidade seria considerada como a única sexualidade possível e normal e, neste contexto, os mecanismos sociais que aterrorizariam as pessoas a serem obrigatoriamente heterossexuais [o heteroterrorismo] não eram criticados.

${ }^{1}$ A teoria queer é constituída por muito(a)s autore(a)s de diferentes perspectivas. Esta expressão foi cunhada por Teresa de Lauretis em 1991, para identificar marcas comuns nas diversas pesquisas vão surgindo, principalmente a partir da década de 80 nos EUA, contextualizadas socialmente pelo surgimento da epidemia da AIDS (MISKOLCI, 2016). O termo queer significa estranho, talvez ridículo, raro, excêntrico ou extraordinário (LOURO, 2001). 
Berenice Bento denominou assim a terceira perspectiva sobre a explicitação da constituição da identidade de gênero de plural, tendo como principal referência teórica o livro Problemas de Gênero: feminismo e subversão da identidade, da filósofa Judith Butler.

Atualmente, a perspectiva de gênero de Judith Butler é considerada de fundamental importância para entendermos as razões pelos quais existe o binarismo de gênero e de que maneira este binarismo é utilizado socialmente como justificativa para sustentar a violência contra a diversidade de gênero e sexual.

O gênero não é uma inscrição cultural sobre um sexo que naturalmente existe nos corpos. Ele não é uma substância e nem uma identidade preexistente que os sujeitos põem em circulação ou apenas passam a executar como consequência dos seus hormônios ou da especificidade de sua genitália. Gênero ou a identidade de gênero é um feito ou um conjunto de atos repetidos regulados por uma relação binária a serviço da "heterossexualidade compulsória". O gênero é fabricado todos os dias pelas pessoas através de atos repetitivos que servem para ocultar o caráter normativo das normas e para construir a ilusão de que gênero está embutido no sexo biológico (BUTLER, 2010).

Vale ressaltar que a "heterossexualidade compulsória" é um conceito que surge por volta de 1980 com Adrienne Rich em seu artigo Heterossexualidade compulsória e a existência lésbica para se referir à heterossexualidade como uma "única forma considerada normal de vivência da sexualidade" (COLLING, 2015, p.24). Diferentemente, a heteronormatividade é considerado o dispositivo contemporâneo das relações entre as pessoas onde a heterossexualidade se apresenta como um modelo social inquestionável ao definir expectativas quanto ao gênero e aos estilos de vida de cada um/uma (MISKOLCI, 2016, p.45). No interior deste dispositivo, todas as orientações sexuais e as sociabilidades devem se organizar conforme a matriz heterossexual (COLLING, 2015).

Judith Butler trabalha com um conceito de "gêneros inteligíveis". Estes gêneros sustentariam uma continuidade e uma coerência entre sexo, gênero, prática sexual e desejo. Neste esquema hegemônico, o sexo exigiria um gênero que, por sua vez, exigiria um desejo em um contexto de heterossexualidade estável e oposicional (BUTLER, 2013). Em outras palavras, o homem padrão "verdadeiro" possuiria os devidos órgãos masculinos, representados fundamentalmente pelo pênis e naturalmente seria 
heterossexual, desejando e mantendo relações sexuais com mulheres. Em oposição, a mulher padrão "verdadeira" possuiria os respectivos órgãos femininos, representados principalmente pela vagina e naturalmente seria heterossexual, desejando e exercendo relações sexuais com homens.

Neste esquema social de "gênero inteligível" tanto o binarismo de gênero quanto a heterossexualidade como norma hegemônica são mantidas performaticamente pelos corpos humanos. E, qualquer pessoa que subverta este esquema será considerada doente, impura, incrédula, sub-humana ou até mesmo uma ameaça para a ordem e o futuro da sociedade. Sendo consideradas como ameaças ou não humanas, estas pessoas diferentes precisam ser eliminadas ao passo que esta eliminação poderá ser considerada como uma defesa social da moral e dos bons costumes, por exemplo. Estas reflexões talvez nos ajudem a compreender por que o Brasil é um dos países do mundo que mais mata a população LGBTQIA+.

Butler explica a reprodução das normas de gênero, assim como a reprodução de qualquer norma através do seu conceito de "performatividade de gênero". Este conceito, mal interpretado ou intencionalmente manobrado pela retórica "ideologia de gênero", representa, na atualidade, um dos principais elementos capitaneados para produzir ódio às teorizações de Judith Butler. Ao contrário daquilo que disseminam os empreendedores morais contra a "ideologia de gênero", a performatividade não é um 'ato' singular e deliberado no sentido de que os sujeitos pudessem escolher suas identidades de gênero livremente. Este conceito se relaciona a "[...] uma prática reiterativa e referencial mediante a qual o discurso produz os efeitos que nomeia" (BUTLER, 2002, p.18). Assim, as normas que regulam o sexo, o gênero e a sexualidade objetivam, performativamente, construir a materialidade dos corpos, dos sexos, dos gênero, especificamente para consolidar o imperativo heterossexual (BUTLER, 2002). A essência do sexo, do gênero ou da sexualidade somente adquire naturalidade e caráter inexorável através de um processo de prática social repetitiva: aquilo que é socializado como natural, não passa de uma construção arbitrária de determinado contexto cultural.

Como reiteração de uma norma ou de um conjunto de normas e não simplesmente um ato singular, a performatividade "oculta ou dissimula as convenções das quais é uma repetição". Esse ato não é primariamente teatral e sua "aparente 
teatralidade se produz na medida em que permaneça dissimulada sua historicidade (e, inversamente, sua teatralidade adquire certo caráter inevitável pela impossibilidade de revelar plenamente sua historicidade" (BUTLER, 2002, p.34).

A noção de performatividade do sexo e do gênero está contra a noção de sujeito voluntarista que vive e existe para além das normas que o regulam. A "performatividade de gênero" se relaciona a uma prática de repetição forçada de regimes de sociais de regulação em que a ação do sujeito "[...] não pode se combinar com o voluntarismo ou o individualismo e muito menos com o consumismo, e em modo algum supõe a existência de um sujeito que escolhe" (BUTLER, 2002, p.38).

Como salientamos anteriormente, gênero é um conceito que desde a sua origem demonstra que os comportamentos, pensamentos, emoções e desejos das pessoas são construídos por determinada sociedade partindo da diferença sexual para organizar, controlar e legitimar normas historicamente definidas. As pessoas e os grupos sociais que falam de uma "ideologia de gênero" objetivam desqualificar o caráter científico do gênero e, para tanto, colam o adjetivo ideologia no termo gênero para gerar a seguinte confusão nas pessoas que ainda não conhecem as perspectivas de gênero: em última instância, eles ou elas querem incutir a falácia de que todas as conceituações de gênero, fundamentalmente a perspectiva plural ou desconstrutivista, não passam de ideias destrutivas dos "inimigos" da família tradicional, da ordem heterossexual e dos bons costumes.

O termo "ideologia de gênero" constitui uma noção criada por discursos fundamentalistas - não pertencente às teorizações feministas - para desqualificar os sujeitos, seus comportamentos e práticas, além de suas vivências sexuais (MARAFON, 2018, p.118), que fogem aos padrões hegemônicos de gênero e sexualidade. É uma retórica acionada para se opuser às produções generificadas que não se enquadram no modelo social de gênero consensualmente aceito (Op., Cit) onde sexo determinaria gênero e sexualidade. Através deste discurso de "ideologia de gênero", determinados setores sociais buscam manter as normas hegemônicas de gênero que excluem, oprimem, violentam ou exterminam qualquer ser humano que não se encaixa a estas normas.

Esta expressão encerra um neologismo ou sintagma retórico e persuasivo utilizado por um ativismo religioso para mobilizar a arena pública em torno de 
estratégias que visam atacar políticas e práticas de igualdade de gênero e outros direitos fundamentais que vem sendo conquistados recentemente (JUNQUEIRA, 2018)

A "ideologia de gênero" é uma "gramática político moral" que se originou no contexto da Igreja Católica, especificamente nos textos do cardeal Joseph Ratzinger. Esta gramática é acionada por "empreendedores morais" para definir o Estado como instituição masculina, heterossexual e contrária à expansão dos direitos humanos àqueles que ameaçam seu mundo tradicional (MISKOLCI; CAMPANA, 2017).

Nesta cruzada contra o gênero, o foco da mobilização política e discursiva é a reafirmação das hierarquias sexuais, a negação dos direitos sexuais e a repatologização das homossexualidades e transgeneridades com a retirada da educação para a sexualidade nas escolas (JUNQUEIRA, 2018, p. 451). Para este autor, as estratégicas discursivas desta retórica "antigênero" objetivam combater as concepções desnaturalizantes de corpo, gênero e sexualidade e promover a rebiologização da diferença sexual, assim como a renaturalização da ordem social, moral e sexual tradicional (JUNQUEIRA, 2018, p. 452). Em resumo, renaturalizar ou reforçar as normas de gênero e a heteronormatividade, através da negação e abjeção às diversidades que existem.

Os "empreendedores morais" em sua saga contra a "ideologia de gênero" buscam principalmente combater as epistemologias científicas e filosóficas que desconstroem as interpretações heteronormativas e/ou heteroterroristas de gênero, sexualidade e do desejo sexual e amoroso. Assim, as perspectivas de gênero construtivista e desconstrutivista ou relacional e plural, constituem os principais alvos sobre os quais uma atmosfera social de pânico é construída e performada, especialmente, no interior das instituições de ensino básico.

Os polemizadore(a)s "antigênero" acusam a "ideologia de gênero" por vaticinar uma possibilidade individual do gênero, da identidade e do corpo (JUNQUEIRA, 2018, p. 454). Nestes termos, Butler foi eleita como a maior inimiga destes polemizadore(a)s. Entretanto, as teorizações desta filósofa não se vinculam à teses voluntaristas de gênero. Não apenas Judith Butler, mas todo(a)s pesquisadore(a)s e intelectuais que movimentam estudos de gênero e sexualidade, precisam ser minado(a)s e descaracterizado(a)s para que as críticas e as reflexões que socializam não atrapalhem os projetos de poder heterossexista e heteronormativo deste(a)s polemizadore(a)s. 
Para Junqueira (2018), a estratégia indispensável para promover essa descaracterização é o pânico moral liderado por estruturas eclesiásticas, organizações e movimentos sociais e religiosos de diversos setores e forças políticas.

Este pânico moral pretende deslegitimar o poder crítico e desnaturalizador dos estudos de gênero e desqualificar todas as reivindicações sociais que tais estudos proporcionam (JUNQUEIRA, 2018) por exemplo a igualdade de gênero, a legalização do abordo, a criminalização da Igbtfobia, o casamento homoafetivo, o reconhecimento dos diversos formatos familiares, a despatologização das sexualidades dissidentes e o reconhecimento das diversidades sexuais e de gênero.

O combate engendrado pelos empreendedores morais contra a "ideologia de gênero" parece se resumir em duas finalidades: calar/excluir/negar ou abjetar qualquer discussão científica - construtivista ou desconstrutivista - sobre estas temáticas; e, ao mesmo tempo, circular os discursos heteronormativos e/ou "heteroterristas" cuja movimentação nos espaços de sociabilidade, não apenas brasileiros, geralmente são alavancados.

Assim, a "ideologia de gênero" surge na contemporaneidade como uma intencionalidade política bem definida que não apenas pretende intervir nos processos educacionais, mas fundamentalmente nos processos de deliberação política em todas as esferas de poder. Seu objetivo principal é reagir e minar a proliferação das concepções científicas de gênero e de sexualidade para restabelecer as normas hegemônicas mantidas até então, através de exclusão, terrorismo e abjeção. O escopo principal desta empreitada é a desqualificação e a negação das diversidades de gênero e sexualidade para recolonizar o imaginário social e renaturalizar o binarismo de gênero e, por consequência, a heteronormatividade.

\section{CONSIDERAÇÕES FINAIS}

Historicamente, o percurso dos estudos de gênero é marcado por perspectivas diversas que objetivam problematizar a associação imediata entre sexo biológico e identidade social. Do questionamento dos essencialismos até a desconstrução destes, as concepções científicas de gênero e de sexualidade permitiram o desvelamento dos processos arbitrários, culturalmente situados, de dominação, opressão, desigualdade e 
violência legitimados por normas sociais que buscam performar a naturalidade destes processos reiteradamente.

A potencialidade crítica e revolucionária dos estudos de gênero estão sob ataque porque além de promoverem a desnaturalização da violência contra a mulher, da patologização das diversidades de gênero e sexual e da destruição dos direitos humanos, permitem a conscientização fundamentada pela reflexão científica acerca da performatividade destes processos.

A "ideologia de gênero" surge, neste sentido, como uma contraofensiva de combate aos estudos científicos de gênero para evitar a revelação do caráter performativo da identidade de gênero e sexual, assim como de qualquer norma, e a desconstrução do lugar privilegiado e natural que a heterossexualidade tinha há muito tempo.

Talvez o (re) conhecimento dos principais achados científicos dos estudos de gênero possam instrumentalizar os sujeitos da contemporaneidade frente às polêmicas "antigênero" e a proliferação de pânicos morais que, no Brasil, são capitaneadas pelo movimento "Escola Sem Partido".

\section{REFERÊNCIAS}

BENTO, Berenice. A reinvenção do corpo: sexualidade e gênero na experiência transexual. Rio de janeiro: Garamond, 2006.

BUTLER, Judith. Corpos em aliança e a política das ruas: notas para uma teoria performativa de assembleia. Trad. Fernanda Siqueira Miguens. 1.ed. Rio de Janeiro: Civilização Brasileira, 2018.

. Problemas de Gênero: feminismo e subversão da identidade. Trad. Renato Aguiar. 3. Ed. Rio de Janeiro: Civilização Brasileira, 2010.

. Corpos que pesam: sobre os limites discursivos do "sexo". In: LOURO, Guacira Lopes (org). O corpo educado: pedagogias da sexualidade. Trad. Tomaz Tadeu da Silva. 3. Ed. Belo Horizonte: Autêntica Editora, p. 151-172, 2013.

Cuerpos que importan: sobre los limites materiales y discursivos del 'sexo'. 1.ed. Buenos Aires: Paidós, 2002.

CORREA, Mariza. Não se nasce homem. Encontros Arrábida. Trabalho apresentado no Encontro "Masculinidades/Feminilidades". Portugal, 2004. Disponível em: http://www.clam.org.br/bibliotecadigital/uploads/publicacoes/942_926_naose nascehomem.pdf. Acesso em 05 jul. 2020. 
COLLING, Leandro. O que perdemos com os preconceitos. In: Revista cult: dossiêditadura heteronormativa, São Paulo-SP, Editora Briantine, n.202, ano 18, p.2225, junho/2015.

FOUCAULT, Michel. Microfísica do poder. Rio de Janeiro: Graal, 1979.

HALL, Stuart. Quem precisa de identidade? In: SILVA, Tomaz Tadeu da (org.). Identidade e diferença. A perspectiva dos Estudos Culturais. Petrópolis, Vozes, 2007, p. 103 a 133.

JUNQUEIRA, Rogério Diniz. A invenção da "ideologia de gênero": a emergência de um cenário político-discursivo e a elaboração de uma retórica reacionária antigênero. Rev. psicol. polít., São Paulo, v. 18, n. 43, p. 449-502, dez. 2018 . Disponível em <http://pepsic.bvsalud.org/scielo.php?script=sci_arttext\&pid=S1519549X2018000300004\&lng=pt\&nrm=iso>. Acessos em 21 jan. 2020.

LOURO, Guacira Lopes. Educação e docência: diversidade, gênero e sexualidade. Form. Doc., Belo Horizonte, v. 03, n. 04, p. 62-70, jan./jul. 2011. Disponível em http://formacaodocente.autenticaeditora.com.br. Acesso em 22 mai. 2016.

LOURO, Guacira Lopes. Gênero, Sexualidade e Educação: uma perspectiva pósestruturalista. 6.ed. Petrópolis: Vozes, 2003.

. Teoria queer- uma política pós-identitária para a educação.

In:

estudos feministas, ano 9, 2. Semestre, 2001, p.451-553. Disponível em: http://www.scielo.br/pdf/ref/v9n2/8639.pdf. Acesso: 18 jan. 2018.

MARAFON, Giovanna. Análises críticas para desmontar o termo "ideologia de gênero".Arq. bras. psicol., Rio de Janeiro , v. 70, n. spe, p. 117-131, 2018 . Disponível em <http://pepsic.bvsalud.org/scielo.php?script=sci_arttext\&pid=S180952672018000400010\&lng=pt\&nrm=iso>. Acessos em 21 ago. 2019.

MISKOLCI, Richard; CAMPANA, Maximilliano. "Ideologia de gênero": notas para a genealogia de um pânico moral contemporâneo. Revista Sociedade e Estado, v. 32, n. 3, p. 725-747, Setembro/Dezembro 2017. Disponível em: http://www.scielo.br/pdf/se/v32n3/0102-6992-se-32-03-725.pdf. Acesso: 18/01/2019.

MISKOLCl, Richard. Teoria Queer: um aprendizado pelas diferenças. Belo Horizonte: Autêntica Editora/UFPO, 2016. 
PRECIADO, Paul Beatriz. Testo Yonqui: sexo, drogas e biopolítica na era farmacopornográfica. Trad. Maria Paula Gurgel Ribeiro. São Paulo: n-1 edições, 2018.

PELÚCIO, Larissa. Desfazendo gênero. In: MISKOLCI, Richard; JÚNIOR, Jorge Leite (orgs.). Diferenças na educação: outros aprendizados. São Carlos: EdUFSCar, 2014.

WEEKS, Jeffrey. O corpo e a sexualidade. In: LOURO, Guacira Lopes. (org.). 0 corpo educado - pedagogias da sexualidade. Belo Horizonte: Autêntica Editora, 2010. 


\title{
CAPÍTULO II
}

\section{"E AI SERÁ QUE EXISTE RACISMO NO MEIO GAY?": CONSIDERAÇÕES SOBRE SEXUALIDADE E RAÇA NAS MÍDIAS DIGITAS}

Patrícia A. Corrêa Mazoti ${ }^{1}$

\begin{abstract}
${ }^{1}$ Mestre em Ciências Sociais e graduada em Filosofia pela UNESP, campus de Marília-SP.
\end{abstract}

\section{RESUMO}

Este trabalho apresenta uma discussão sobre a (in)visibilidade e representatividade de pessoas negras e de sexualidade não-normativas nas mídias digitais. Os dados apresentados foram obtidos por meio da pesquisa realizada com o canal de humor e informação Põe na Roda, seja nas produções de dois esquetes tratando a temática, a saber: "Gays negros e racismo" e "Gays negros reagindo a racismo nos aplicativos", em sua recepção e comentários no YouTube, no grupo no Facebook "Ajuda, Põe na Roda" que é um espaço no qual pessoas LGBTs podem procurar auxílio e a questão da raça é comumente levantada, além de entrevistas com xs seguidorxs do canal. Assim, tratarei da intersecção do marcador social da raça com a sexualidade, pois essa problemática foi apontada em diversas instâncias do campo, principalmente pelxs colaboradorxs da pesquisa que não se veem representados nas produções do canal sendo a falta da abordagem da raça uma das principais críticas estabelecidas ao conteúdo do Põe na Roda. Tendo em vista o contexto histórico e social que permeia a questão de cor/raça no Brasil não é de se espantar que a discussão fora colocada, tanto nos meios de comunicação como a televisão, como também nas mídias digitais, como uma questão inferiorizada. Dessa forma, busca-se compreender os mecanismos pelos quais a hierarquia das diferenças conforma outras formas de exclusões.

Palavras-chave: Raça. Sexualidade. Mídias digitais.

\section{INTRODUÇÃO}

O presente trabalho apresenta resultados da pesquisa em andamento que versa sobre os discursos produzidos pelxs ${ }^{1}$ seguidorxs, através do canal de humor e informação Põe na roda ${ }^{2}$ e do conteúdo disseminado pelos vídeos que são alojados no

${ }^{1}$ Adoto uma grafia inclusiva a fim de contemplar a multiplicidade de gêneros substituindo pronomes, artigos, adjetivos e advérbios que denotem binarismo pelo $\mathrm{x}$.

2 Endereço eletrônico do Põe na
<https://www.youtube.com/user/canalpoenaroda/featured >. 
YouTube. O canal estreou no dia 15 de abril de 2014 e foi idealizado por Pedro Henrique Mendes Castilho (Pedro $\mathrm{HMC}^{1}$ ). O público que pretende atingir é:

O público LGBT que se vê pouco representado na mídia. Você tem programas e canais voltados para donas de casa, pra crianças, para o público masculino que quarta pode escolher entre desfile de lingerie e futebol. Mas vê quase nada para o público gay. Mesmo na Internet são poucas opções ainda no Brasil².

O Põe na Roda também possibilitou a criação de um espaço LGBT de ajuda mútua online, chamado Ajuda, Põe na Roda ${ }^{3}$, dada a sua dinâmica diferenciada, abriu novas possibilidades para o trabalho. Os comentários de outras páginas do Facebook e do YouTube oferecem informações muito singelas sobre a intimidade dxs seguidorxs. Ao contrário destes, o grupo foi criado e tem sido utilizado como um divã, tornando possível o acesso de diversos relatos que possuem um teor bem intimista. Sendo este espaço o principal utilizado para o estabelecimento de contato com xs colaboradorxs desta pesquisa. O grupo fechado foi criado no dia 6 de dezembro de 2015. Passados pouco mais de dois anos de existência do grupo, a articulação de postagens continua a ser diária e conta com aproximadamente 26 mil membros até o momento.

Nas mídias digitais, além da multiplicidade de informações e representações, as escolhas são constituídas e assentadas em princípios de pertencimento, alicerçados em características de cunho subjetivo que, muitas vezes, ultrapassam as demandas relativas às identidades. Além disso, a internet proporciona uma experiência de comunicação que se diferencia de outras mídias consideradas mais tradicionais como a televisão, já que sua apreciação comumente se dá de forma mais individual. Essas questões revelam a importância da contribuição dos estudos sobre as novas articulações da sociedade brasileira, essa que, paulatinamente, vem se reestruturando pela cultura digitalizada e pela "conexão perpétua" (CASTELLS, 2011).

Por isso, neste trabalho tratarei sobre a problemática "cor/raça" que é uma das principais temáticas cobradas do Põe na Roda tanto no YouTube, quanto em postagens

${ }^{1}$ Essa é a referência que o idealizador do Põe na Roda também é chamado. A partir deste momento, utilizarei essa abreviação, Pedro HMC, para me referir a Pedro Henrique Mendes Castilho.

${ }^{2}$ ANGELO, Vitor. Canal voltado para LGBTs estreia com vídeo sobre racionamento de água. 15/04/2014. In: <http://blogay.blogfolha.uol.com.br/2014/04/15/canal-voltado-para-lgbts-estreia-comvideo-sobre-o-racionamento-de-agua/>. Acesso em 04 jan. 2016.

${ }^{3}$ Ajuda, Põe na Roda: <https://www.facebook.com/groups/ajudapoenaroda/?ref=ts\&fref=ts>. 
e nas entrevistas realizadas com integrantes do grupo Ajuda, Põe na Roda, essa que, muitas vezes, denunciam discriminações dentro do "meio LGBT", a falta de visibilidade e representatividade de pessoas negras. Desta forma, os dados são provenientes da pesquisa de recepção realizada nos vídeos - especificadamente "Gays negros e racismo" ${ }^{1}$ e "Gays negros reagindo a racismo nos aplicativos"2 - e comentários no YouTube, bem como nas postagens do grupo “Ajuda, Põe na Roda” e no material etnográfico recolhido nas 22 entrevistas que foram realizadas via inbox ${ }^{3}$. Assim, buscase compreender os mecanismos pelos quais a hierarquia das diferenças conforma outras formas de exclusões.

\section{SEXUALIDADE E RAÇA: A LIMIARIDADE ENTRE "CORPOS DESEJÁVEIS" E "CORPOS EXÓTICOS"}

No dia 2 de agosto de 2017, C.14 postou no Ajuda a seguinte provocação: "E ai Será que Existe Racismo no Meio Gay?"5 e recebeu 160 comentários e 157 reações. Enquanto a maioria dos comentários sinalizaram a existência de racismo, apenas duas pessoas configuraram suas repostas de forma diferente. H.1 discordou ao declarar: "Depende o tipo do racismo se esse racismo for com os afeminados a resposta é ssssssimmmmmmmmmmmmmmm \#Porra", colocando, assim, o preconceito contra "gays afeminados" como racismo. R.1, por sua vez, relativizou a pergunta ao dizer que não percebe muito racismo, mas, na realidade, o que nota é o preconceito com a própria condição de ser gay.

Já N.1 categoricamente afirmou: "Certamente q sim os gays são os mais racistas e preconceituosos". A resposta de N.2 foi rebatida por Pedro HMC que buscou diminuir seu tom negativo: "Nao e assim nao. Racismo e preconceito são problemas da sociedade

${ }^{1}$ Disponível em <https://www.youtube.com/watch?v=tnnVRsdaF5k\&vl=pt> Acesso em 15 jan. 2018.

${ }^{2}$ Disponível em https://www.youtube.com/watch?v=4NgE7jfOZAQ. Acesso em 15 jan. 2018.

${ }^{3}$ Caixa de entrada de mensagens instantâneas alocadas no Facebook.

${ }^{4}$ Nome abreviado por inicial para preservar xs sujeitxs da pesquisa, já que a utilização dos comentários não foi solicitada aos mesmos. No caso de repetição da inicial, será utilizada numeração como forma de diferenciação das pessoas. Estes comentários, realizados pelxs seguidorxs, serão utilizados sem nenhuma alteração, isto é, sem correções gramaticais e ortográficas.

${ }^{5}$ Por questões próprias desse campo de pesquisa, as únicas postagens do Ajuda que utilizo nesta pesquisa sem autorização são aquelas que tratam de tópicos de interesse coletivo e não relatos pessoais, preservando, assim, a intimidade dxs participantes do grupo. 
no geral e que tambem fazem parte do meio gay pq estamos dentro dessa sociedade e inseridos nos mesmos valores culturais e sociais". Colocando-se como um gay negro, I.1 relatou sua experiência na busca por relacionamentos amorosos nos chats (bates papos). Segundo o seguidor, o racismo se manifestava sempre quando ele textualizava as suas características físicas:

Sim existe... Sempre que entrava nos bate papos e conhecia alguém sempre me perguntavam se eu era branquinho e lisinho... E sempre q eu dizia q era negro a pessoa começava a me ignorar. O padrão de gay perfeito é Branco, malhado de olhos claros e cabelos claros de preferência depilados. Caso vc não seja desse tipo, vc é considerado um dos 'exoticos' e vai parar na lista dos fetiches, como se fosse algo estranho (Postado por 1.1 no grupo Ajuda, Põe na Roda em 02 de agosto de 2017).

Na verdade, a separação entre "corpos desejáveis" e "corpos exóticos" não é uma exclusividade do meio LGBT. De fato, essa problemática revela a complexidade pela qual a questão de cor/raça se apresenta na sociedade brasileira, como aponta Edi: "raça é uma coisa complicada kkkk meus pais são negros porém tenho a pele branca e olhos verdes, falo a sou negra e o povo me olha torto" (Em entrevista concedida à pesquisadora em 24/08/2017 por meio do inbox do Facebook).

Para além de sua sexualidade, Hernane também destaca esta categoria enquanto marcador importante de sua experiência social. Ele se considera "negro, mesmo tendo que mostrar uma 'carteirinha' de negro" (Em entrevista concedida à pesquisadora em 23/09/2017 por meio do inbox do Facebook). Isto porque sua mãe é branca e seu pai é negro e, por isso, ele é um "negro, com a pele mais clara". No entanto, sua autoidentificação geralmente não é respeitada, já que ele ressaltou que, nos círculos sociais que frequenta, não é aceito como negro, pois a sua pele mais clara denotaria privilégios sociais provenientes desta posição.

É o próprio interlocutor que aponta o quanto esta categoria é arenosa no país, pois para ele o "Brasil tem conceito de raça muito curioso que passa pela coloração da pele conheço gente que mesmo tendo pais negros e um tom de pele mais claro se consideram brancos" e continua "Já ouvi absurdos de gente com tom de pele mais escura que a minha entender-se com moreno claro. Acho tudo isso muito confuso" (Em entrevista concedida à pesquisadora, em 23/09/2017 por meio do inbox do Facebook). 
Em outras palavras, "o negro quer ser branco. O branco incita-se a assumir a condição de ser humano" (FANON, 2008, p. 27).

Sabe-se que, no Brasil, criaram-se diversos processos sociais para encobrir as violências sociais. Assim, o entender-se como uma pessoa negra perpassa um rompimento com toda uma estrutura social e cultural, pois "a cor não é nada, nem mesmo a vejo, só reconheço uma coisa, a pureza da minha consciência e a brancura da minha alma. 'Eu - dizia o outro - branco como a neve'” (FANON, 2008, p. 163). Neste sentido, considerar-se branco e/ou negar-se enquanto uma pessoa negra aciona-se como uma tentativa de contornar a abjeção que os corpos e subjetividades negras vivenciam numa sociedade que possui o racismo enquanto um componente estrutural e, por isso, institucionalizado.

Para compreender a importância e as ambiguidades sociais das questões acerca da raça no Brasil, Schwarcz (2012) observa que as teorias raciais chegaram ao país no século XIX. A história nacional é marcada pela escravidão e as mudanças sociais que empregou, como, por exemplo, a mudança das cores da pele dos habitantes do país e de seus costumes através da miscigenação, tornou aceitável socialmente a inferiorização das pessoas negras através da violência e das diversas desigualdades sociais.

A antropóloga chama atenção para a ênfase dada na desigualdade biológica entre os seres humanos através do positivismo determinista europeu que buscou explicar a diferença e superioridade da raça branca por meio da ciência. No entanto, as teorias do darwinismo social europeias não foram plenamente incorporadas no Brasil sem uma ressignificação, pois a mestiçagem não foi tomada como um sintoma de degeneração social e econômica do país.

Contudo, defender a mestiçagem não se fez enquanto sinônimo de negar a suposta superioridade das pessoas brancas sobre as demais, pelo contrário: ao mesmo tempo em que se defendia a mestiçagem, continuava-se a sustentar no Brasil as hierarquias raciais. Após o fim da escravidão, empreendeu-se incentivos para a imigração com a intenção de efetuar uma política de branqueamento na população brasileira. Já nos anos de 1930, o "mestiço" transformou-se em uma representação oficial da nação através do elogio à mestiçagem. Paralelamente a esse processo, ocorreu uma desafricanização de inúmeros elementos da cultura negra africana que também 
foram transformados em nacionais, como, por exemplo, a feijoada, a capoeira, o samba e a Nossa Senhora da Conceição Aparecida, elementos colocados como representação da mestiçagem.

Aníbal Quijano (2000) oferece uma reflexão para a classificação social que ocorre através da "questão do trabalho, da 'raça' e do 'gênero', as três instâncias centrais a respeito das quais se ordenam as relações de exploração/dominação/conflito" (QUIJANO, 2000, p. 104). Assim, a distribuição do poder por meio dos "processos de classificação, desclassificação e reclassificação social" (QUIJANO, 2000, p. 102) ocorrem na associação dessas três instâncias. $O$ autor demostra que as relações entre raças são feitas através da dominação e que a distribuição do poder transcorre por meio da "naturalização das categorias sociais que dão lugar a esses elementos no poder" (QUIJANO, 2000, p. 106) e, por isso, necessita de um mecanismo subjetivo para funcionar. A racialização seria, então, uma das instâncias que mais evidencia o caráter eurocêntrico do poder colonial (QUIJANO, 2000).

\section{YOUTUBE: ESPAÇO DE (IN)VISIBILIDADE PARA A CONSTRUÇÃO SOCIAL DAS DIFERENÇAS}

Diante de todo esse contexto histórico e social que permeia a questão de cor/raça no Brasil não é de se espantar a invisibilidade de pessoas negras tanto nos meios de comunicação como a televisão, como também nas mídias digitais. A interlocutora Amanda que se coloca como mulher negra e lésbica ressaltou a ausência de abordagens sobre racismo no canal Põe na Roda. Ao perguntar se ela conhecia pessoas negras que possuíam canais no YouTube e que tratavam de gênero e sexualidade a sua resposta foi: "YouTubers que acompanho, acho que nenhum é negro" (Em entrevista concedida à pesquisadora, em 10/07/2017, por meio do inbox do Facebook).

Após várias reclamações e pedidos feitos pelxs seguidorxs do Põe na Roda, o canal decidiu abordar a questão. O vídeo "Gays negros e racismo" foi lançado no quadro Sauna Justa ${ }^{1}$ em 05 de outubro de 2016 e foi o primeiro esquete do canal que buscou

${ }^{1} \mathrm{O}$ nome do quadro Sauna Justa é uma paródia do programa de televisão exibido no canal por assinatura brasileiro GNT "Saia Justa", este que possui um elenco feminino que debate assunto do interesse das mulheres "modernas", pois "nada é tabu para as mulheres do Saia". A utilização do "sauna" se justifica pela expressão que essa localidade confere para a sociabilidade gay, oportunizando encontros sexuais. 
tratar o marcador social cor/raça em intersecção com a sexualidade.

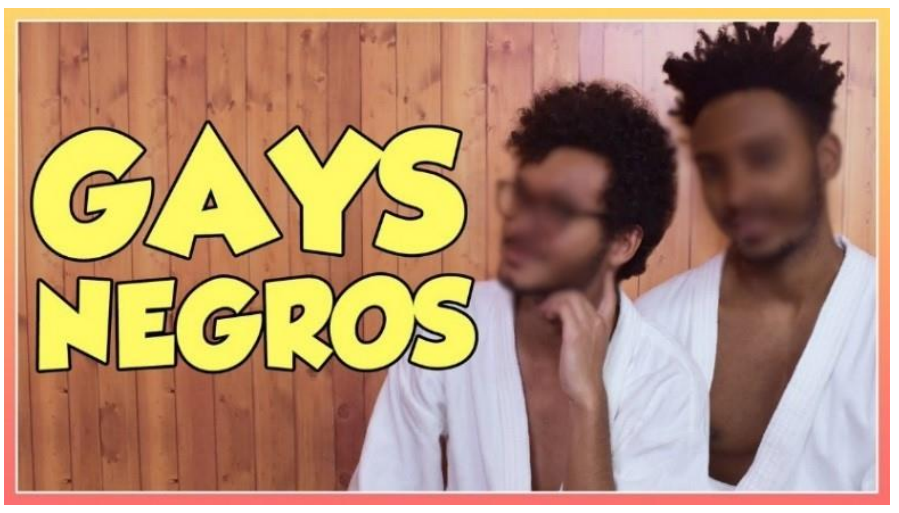

Imagem 1 - Capa do esquete "Gays negros e racismo", lançado em 05 de outubro de 2016 no quadro Sauna Justa do Põe na Roda.
Os dois participantes negros foram Alberto, integrante do elenco rotativo do canal com participação em sete vídeos; e Joely, um dxs seguidorxs que criticou o canal pela falta de representatividade de pessoas negras de gênero e/ou sexualidades não-normativas. A

repercussão deste esquete, como analisado por A.1 (2016) teve "beeeem menos views [visualizações] do que os outros já diz muitas coisas, diz inclusive que brancos (grande maioria de inscritos nesse canal, imagino) estão pouco se fodendo" (Comentário no vídeo “Gays negros e racismo" no YouTube em 2016).

As questões que foram levantadas nesta produção remeteram-se: aos bairros paulistanos que as pessoas negras poderiam transitar em segurança; a relação entre pobreza e escravidão; a questão da beleza e corpos negros serem tomados como "exóticos" e a recente escolha de transição capilar por jovens negrxs brasileirxs que expressa resistência diante da imposição do alisamento do cabelo crespo e/ou cacheado.

Joely ressalta que "gosto é uma construção social" e não apenas uma escolha individual. Na caixa de comentários do vídeo em questão no YouTube, a ideia de "construção social" foi rebatida por A.2 (2016) que disse: "Detesto esse povo de humanas... Que construção o quê! A maioria dos comportamentos humanos deriva de imperativos biológicos" (Comentário no vídeo "Gays negros e racismo" no YouTube, em 2016). S.1 também concordou com a falibilidade do conceito e a necessidade de retirada do peso que os entrevistados colocaram no racismo. Em outras palavras, o apelo para as explicações cientificas, como já visto no darwinismo social, ainda continua em voga, a saber:

Concordo, o padrão de beleza imposto pela sociedade tem um limite, um certo alcance, a maior base para a atração física e estética é biológica, como a predileção humana por rostos mais simétricos e 
harmonia entre os traços da face - os elementos da face com posição e tamanhos que se equilibram. Além disso é intrínseco à maior parte dos humanos associar certas tonalidades de pele à doenças. Exemplo: A maioria dos humanos associa vermelhidão à inflamação, pele arroxeada à hematomas, doenças cardiovasculares ou hepáticas que manifestam sintomas na pele. É uma configuração biológica associar saúde à beleza, pois nosso corpo é adaptado a se reproduzir quer queiramos ou não. Mesmo no caso dos gays é assim, os espermas são férteis e a tendência é sentir-se atraído para o que parece ser saúdavel e, por conseguinte, mais promissor de gerar uma descedência - mesmo que no caso de uma pessoa do mesmo sexo não se pode reproduzir pelo intercurso (Comentário no vídeo "Gays negros e racismo" no YouTube, em 2016).

No vídeo, Pedro HMC coloca na discussão os limites entre a visibilidade e da objetificação através de uma reportagem no Superpride ${ }^{1}$ que tratou os 35 ruivos mais lindos do mundo ${ }^{2}$. Na ocasião, militantes negros acusaram a falta de representação da beleza negra e, por isso, foi realizada uma reportagem com os 10 negros mais lindos do mundo ${ }^{3}$. Porém, Pedro HMC destacou que outras pessoas também militantes acusaram a reportagem de objetificar o corpo negro. Para os entrevistados, o problema se concentra no fato que, ao falar de beleza, foi realizada uma segregação, no caso, "beleza negra" e "beleza ruiva", sendo que, na verdade, dificilmente se lançaria uma reportagem sobre "beleza branca". A saída proposta pelos mesmos seria tratar a beleza e estendêla a pessoas de diferentes raças/cores em conjunto e não separado para que não as conformassem na categoria de "exóticas".

Além disso, ressaltaram o fato de que a identidade negra, no senso comum, é associada à virilidade, ao potencial dos órgãos genitais e à imagem da masculinidade do "negão" que é cobrado para ser o "ativo"4 na relação. Pode-se observar essa exigência no comentário de A.7: "Mas vocês forçam a barra as vezes né ninguém merece sair com um negro e afeminado. Se o cara for negro e macho jamais sofrerá preconceito no mundo gay" (Comentário no vídeo "Gays negros e racismo" no YouTube, em 2016).

Outra questão apontada foi o relacionamento amoroso entre pessoas negras e brancas, pois ter um namorado branco é considerado, por vezes, uma espécie de prêmio

\footnotetext{
${ }^{1}$ Disponível em: http://www.superpride.com.br/>.

${ }^{2}$ Disponível em: http://www.superpride.com.br/2013/07/os-35-homens-ruivos-mais-lindos-domundo.html>.

${ }^{3}$ Disponível em: <http://www.superpride.com.br/2013/08/os-homens-negros-mais-lindos-domundo.html >.

${ }^{4} \mathrm{O}$ sujeito que irá penetrar o outro na relação sexual.
} 
social. Fanon (2008) não trata o relacionamento homossexual entre pessoas negras e brancas, mas sentiu a necessidade de escrever dois capítulos que abordavam o relacionamento amoroso, a saber: "A mulher de cor e o branco" e "O homem de cor e a branca". Suas considerações mostram que o destaque dado ao "privilégio" de se ter parceirxs brancxs ocorre devido a questão estética e do poder econômico que, em virtude das normas que regulam a sociedade, associa-se às pessoas brancas. Além disso, destaca que tal "privilégio" seria uma via mais fácil e rápida para as pessoas negras tornarem-se brancas, pois:

Da parte mais negra de minha alma, através da zona de meias-tintas, me vem este desejo repentino de ser branco.

Não quero ser reconhecido como negro, e sim como branco.

Ora - e nisto há reconhecimento que Hegel não descreveu - quem pode proporcioná-lo, senão a branca? Amando-me ela me prova que sou digno de um amor branco. Sou amado como um branco.

Sou um branco.

Seu amor abre-me o ilustre corredor que conduz à plenitude...

Esposo a cultura branca, a beleza branca, a brancura branca.

Nestes seios brancos que minhas mãos onipresentes acariciam, é da civilização branca, da dignidade branca que me aproprio (FANON, 2008, p. 69).

Os dois entrevistados já tiveram envolvimento amoroso com pessoas brancas e relataram como o seu meio social receberam essas relações inter-raciais. Ao apresentar seu namorado branco para as pessoas de seu convívio, Joely sentiu-se como se ele tivesse obtido um "troféu" e seu parceiro era constantemente coberto de inúmeros elogios em relação a seus atributos físicos. Alberto, por sua vez, relatou sentir o mesmo quando era casado com um alemão. A "escolha" por estar com uma pessoa branca evidenciada por Alberto foi criticada no comentário de C.2 que apontou:

Apenas considero triste que lutem pela valorização da beleza negra e quase sempre escolhem um branco ou alguém 'mais claro' como companheiro. É como se o discurso fosse um e a atitude outra. A verdade é que no Brasil, ao contrário da maioria dos países que possuem quantidades significativas de populações brancas e negras, 0 negro só é aceito se está em uma relação interracial, sejas nas relações homossexuais ou heterossexuais. Isso não é verdadeiramente aceitar. A inclusão não se dá quando a protagonista da novela é negra e namora um branco, a verdadeira inclusão é quando um casal Negro é capaz de interpretar naturalmente os dois papeis (Comentário no vídeo "Gays negros e racismo" no YouTube, em 2016). 
A recepção do vídeo causou desconforto em F.1, pois considerou que os entrevistados explicaram "de maneira bonitinha o que é racismo". Para ele, "os temas deveriam ser abordados com mais profundidade e não simplesmente no sentido do que é uma conduta aceitável do branco em relação ao negro" (Comentário no vídeo "Gays negros e racismo" no YouTube, em 2016). Já K.1 considerou que os dois entrevistados reforçaram o discurso do "vitimismo", pois:

Pra mim isso tudo é mimi... Sou negro e não sinto esse preconceito todo não. sou da periferia e quando vou para os lugares 'brancos' não me sinto nem um pouco de preconceito. O preconceito está na propria cabeça. Quando alguem fala que nao fica com negro, não é preconceito é apenas opção. Não me sinto nem um pouco representado por esses negros vitimistas.! (Comentário no vídeo "Gays negros e racismo" no YouTube, em 2016)

Ao indagar Hernane sobre o vídeo em questão, ele disse "vc vê que curiosa a fala dele [referindo-se ao Pedro HMC] de: 'Estava hesitante, porque não queria que este vídeo fosse um vídeo sobre negros'. Pra mim soa cota". Para Hernane, a associação estabelecida entre a visibilidade de gays negros com a questão de cota racial expressa pelo discurso de Pedro HMC confirmou o seu próprio lugar de fala: de um "branco de classe média". Ao indagá-lo se o lugar social de Pedro HMC o isentava de ter uma reflexão sobre a realidade das pessoas negras, Hernane pontuou: "Não, acho que isso o limita" (Em entrevista concedida à pesquisadora em 26/09/2017 por meio do inbox do Facebook).

Em "Gays negros e racismo" também foi levantada a questão de como raça/cor se manifesta nos aplicativos utilizados por LGBTs que se destinam à procura de encontros sexuais e relacionamentos amorosos. Os entrevistados destacaram que é muito comum encontrar nas descrições dos interesses de usuárixs frases como "não pego japoneses, negros". Para Alberto, a regularidade com que essas categorias são utilizadas para a procura de parceiros sexuais escancara o racismo. Em outras palavras, a lógica normativa que classifica e separa os "corpos desejáveis" dos "corpos exóticos" é aquela que também impera nos aplicativos, afinal, segundo Miskolci (2017),

No universo dos aplicativos, a aparente abundância de parceiros é contrabalanceada pelo contexto de mercado amoroso sexual, no qual vigora uma competição generalizada pelos perfis considerados mais 
desejáveis, enquanto a maioria dos outros perfis encontra várias formas de discriminação, rejeição e frustração (MISKOLCI, 2017, p. 221).

Na discussão do assunto, muitxs seguidorxs do canal manifestaram o incômodo gerado pela objetificação de seus corpos, como L.1 que é negro, tem dois metros e disse que a "única pergunta que recebo no app é: Ativo? roludo"? ?!". Joely destaca que, embora

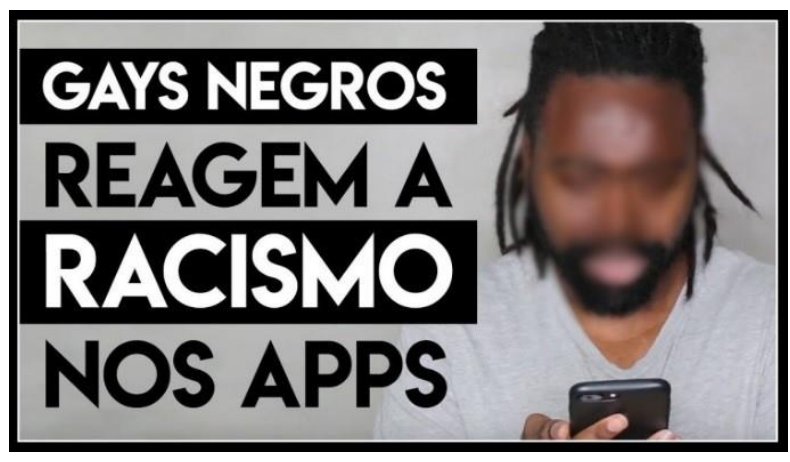

o racismo atinja o movimento LGBT e o "meio gay" de forma diferente, não se pode perder de vista que estas práticas continuam sendo racismo e, por isso, é preciso discuti-las, problematizá-las e combatê-las.

Esta temática dos aplicativos foi utilizada como roteiro para outra produção do

Imagem 2-Capa do esquete, "Gays negros reagindo a racismo nos aplicativos -

\#ConscienciaNegra" lançado em 16 de novembro de 2017 canal, "Gays negros reagindo a racismo nos aplicativos", lançado em 16 de novembro de 2017 em virtude do Dia

da Consciência Negra, celebrado em 20 de novembro e também como uma reação ao comentário racista "é coisa de preto" proferido pelo jornalista William Wack na Rede Globo ${ }^{2}$. Na descrição do vídeo, foi ressaltada a necessidade de se discutir e reconhecer "o racismo que também existe dentro do meio LGBT".

Cerca de três meses após seu lançamento, esta produção já possui praticamente o dobro de comentários (1087) do vídeo anterior, mas manteve a mesma média de sua visualização (aproximadamente 100 mil). Os três participantes Joely, Silvano da Silva Júnior e Samuka comentaram prints de mensagens e perfis que expunham conteúdos racistas nos aplicativos Grindr, Hornet, Scruff e Tinder. O teor dos conteúdos segue a lógica do seguinte perfil analisado pelos participantes:

\footnotetext{
${ }^{1}$ Sujeito que possui órgão genital masculino (pênis) avantajado em tamanho.
}

${ }^{2} \mathrm{O}$ vídeo gravado por Diego Rocha Pereira mostra William Waack cobrindo a campanha eleitoral dos Estados Unidos em 2016. Alguns minutos antes de entrar ao vivo, Waack incomodou-se com um carro que estava buzinando na rua e, por isso, emitiu xingamentos. Além disso, falou para um convidado do programa, em tom baixo, que o barulho certamente "é coisa de preto". Ele continuou a reclamar das buzinadas e exclamou "eu sem quem é... "É preto". Disponível em: <https://brasil.elpais.com/brasil/2017/11/09/politica/1510184872_072863.ht ml?rel=str_articulo\#1518306655698> Acesso em 15 fev. 2018. 


\section{O que procuro}

Antes de chamar, veja se você está em algum item do filtro abaixo, caso esteja por favor não perca seu tempo.

$1^{\circ}$ Velhos? Nada contra, só acho que seu lugar é na Estação 2000 e não perto de mim.

$2^{\circ}$ Negros? Não sou racista, não tenho nada contra, só não curto mesmo. Gosto é gosto, por favor respeitem isso.

$3^{\circ}$ Afeminados? Prefiro que continuem na Praça Raul Soares ou no show de Bate Cabelo.

$4^{\circ}$ Gordos? Não sou hipocondríaco, não sou; mas eu fico temeroso com corpos moles e gelationosos principalmente na cama, então sem chances.

$5^{\circ}$ Drogados? Faça um tratamento e parem de ir no after, não quero pegar ninguém que mora debaixo do viaduto.

$6^{\circ}$ Burros? Ensino médio completo é requisito mínimo para dialogar comigo, curso superior desejável. (Exibido em "Gays negros reagindo a racismo nos aplicativos - \#ConscienciaNegra", pelo Põe na Roda no YouTube em 2017).

“Começou assim já 'não sou racista' nem precisa ler o resto" reagiu Samuka. Mas, mesmo assim, ele continuou a ler. Quando chegou na parte "gosto é gosto", problematizou a questão: "não, não, não, isso não é gosto, isso é preconceito. Sabe, a nossa sociedade foi ensinada a aceitar o belo eurocentrizado, o belo branco". É interessante observar que as mídias digitais e a sua incorporação no nosso cotidiano "não inventam novos racismos, mas antes elas reproduzem de forma inovadora os estereótipos raciais, afiando ainda mais a foice que vem fazendo cortes dos desejos" (KURASHIGE, 2014, p. 29).

\section{CONSIDERAÇÕES FINAIS}

Em "O negócio do michê: a prostituição viril”, Néstor Perlongher evidencia que ser negro se coloca como um fator de inferiorização no gueto gay (1987, p.151). Como podemos perceber na abordagem estabelecida neste trabalho, não houve alterações profundas no quadro identificado por Perlongher, pois ser negrx no Brasil ainda "persiste como representação poderosa, como um marcador social de diferença - ao lado de categorias como gênero, classe, região e idade, que se relacionam e se retroalimentam - a construir hierarquias e delimitar discriminações" (SCHWARCZ, 2013, p. 34). 
Na hierarquia das diferenças, infelizmente, menos é mais: quanto menor o número de marcadores sociais da diferença em uma pessoa, maior serão suas chances de existência e sobrevivência. Assim, as diferentes dos corpos negros de pessoas de gênero e/ou sexualidades não-normativas desafiam preceitos históricos, morais e biológicos que alicerçam as hierarquias de poder na sociedade. Dessa forma, essas vivências são lidas como transgressões não consentidas e, por isso, são expurgadas através do rechaço e da aversão social, da exclusão e da abjeção. Por isso, mesmo que as mídias digitais sejam um espaço que proporcionam e potencializam produções que abordam outros marcadores, no jogo da (in)visibilidade o espaço ainda é ocupado por aquelxs que mais se enquadram nas normas sociais, pois a hierarquia das diferenças conformam outras formas de exclusões.

Apesar disso, xs colaboradorxs desta pesquisa, e muitas outras pessoas, continuam a resistir e se mostram resilientes quanto a qualquer forma de assimilação. É através delas que a sociedade poderá aprender (quem sabe de uma vez por todas) que todos os corpos e vivências importam, pois, nas intersecções das diferenças, mais é mais e ponto final.

\section{REFERÊNCIAS}

CASTELLS, Manuel. Sociedade em Rede. São Paulo: Paz e Terra, 2011.

FANON, Frantz. Pele negra, máscaras brancas. Tradução de Renato da Silveira. Salvador: EDUFBA, 2008.

KURASHIGE, Keith Diego. Marcas do desejo: um estudo sobre os critérios de "raça" na seleção de parceiros em relações homoeróticas masculinas criadas online na cidade de São Carlos. Dissertação apresentada ao Programa de Pós- Graduação em Sociologia da UFSCar para obtenção do grau de Mestre em Sociologia, 2014. Disponível em: <http://www.ufscar.br/cis/wpcontent/uploads/Dissertac\%CC\%A7a\%CC\%83o-Keith.pdf> Acesso em: 24 de set. 2017.

PERLONGHER, Néstor. O negócio do michê: a prostituição viril. São Paulo, Brasiliense, 1987.

QUIJANO, Aníbal. Colonialidade do Poder e Classificação Social. In: SANTOS, B. S.; MENESES, M. P. Epistemologias do Sul. São Paulo: Cortez, 2010, p. 73-118. 
MISKOLCI, Richard. Desejos digitais: uma análise sociológica da busca por parceiros online. 1. ed. Belo Horizonte: Autêntica, 2017. v. 1. 303p.

SCHWARCZ, Lilia Moritz. Nem Preto nem branco, muito pelo contrário: cor e raça na sociedade brasileira. São Paulo: Claro Enigma, 2012. 


\title{
CAPÍTULO III
}

\section{ATOS DE RESISTÊNCIA: ESTRATÉGIAS DE LUTA DAS MULHERES ESCRAVIZADAS E O PESO DO SEXISMO NO FINAL DO SÉCULO XIX EM SANTA CATARINA}

\author{
Cíntia Magnus Gomes ${ }^{1}$ \\ Marina da Silva Schneider ${ }^{2}$
}

\begin{abstract}
${ }^{1}$ Graduada em História pela Universidade do Extremo Sul Catarinense - UNESC
2 Mestranda em Desenvolvimento Socioeconômico na Universidade do Extremo Sul Catarinense. Graduada em História - UNESC.
\end{abstract}

\section{RESUMO}

A sociedade brasileira atual é fruto de uma colonização de exploração, que além de ter nos deixado como herança a mestiçagem da população entre europeus, indígenas e negros, permitiu que resquícios do sistema escravocrata e patriarcal aqui implantado, respingassem sobre os remanescentes da escravidão sob a forma de preconceito racial e desigualdade social ainda tão presentes. E se considerarmos a condição de escravo no Brasil colonial difícil, o sexismo e as desigualdades de gênero pesavam ainda mais para a condição da mulher escrava. O presente artigo buscou compreender esta dominação sobre as mulheres escravas sob um viés dos estudos de gênero na intersecção com raça, tentando definir o papel delas como sujeitos históricos e suas formas de resistência dentro de um sistema que as oprimia duplamente, por serem escravas e por serem mulheres. Utilizando-se de uma bibliografia de estudos já realizados sobre o tema, objetivamos dar visibilidade a essas mulheres escravas e tentamos explanar aqui aspectos da vida cotidiana e estratégias estabelecidas por elas em busca de melhores condições de vida ou por sua liberdade no Brasil, mas de forma mais específica, no Sul de Santa Catarina.

Palavras-chave: Gênero; Mulheres; Escravidão, Resistência.

\section{GÊNERO COMO UMA CATEGORIA HISTÓRICA ANALÍTICA}

Como estratégia teórica, alicerçamos nossa análise no campo da história das mulheres e das relações de gênero, levando em conta que essa discussão se faz necessária para alargar a compreensão sobre as relações humanas entre homens e mulheres, bem como as desigualdades presentes nessas relações sociais em diferentes tempos e espaço da história. Mais especificamente nesse caso, tentamos compreender essas relações de mulheres escravizadas sob um viés de gênero. 
Para Joan Scott (1995), o gênero é uma categoria relacional e pode ser entendido como uma parte que constituiu as relações culturais que são baseadas nas diferenças percebidas entre os sexos e nas relações de poder. Em outras palavras:

Os estudos de gênero consideram que a vida social e os vetores que organizam como, por exemplo, tempo, espaço ou a diferença entre os sexos, são desenvolvidos e estabelecidos socialmente através de um sistema de representações. (KUAMOTO; LOSNAK, 2015, p. 08).

Desse modo, esses estudos visam repensar as formas como as relações são construídas e interpretadas pelos sujeitos, uma vez que, em grande medida, se transformam em desigualdades, violências e invisibilidades contra as mulheres. Podemos interpretar a partir da análise de Scott (1995), que as relações históricas entre homens e mulheres se construíram marcadas pelas desigualdades de gênero a partir de uma hierarquia existente que criava normatividades impostas as pessoas. Para Margareth Rago (1998), apenas as questões econômicas e políticas não são suficientes para explicar as desigualdades entre homens e mulheres no interior da cultura. É preciso analisar como essa sociedade constrói e interpreta seus sentidos.

Scott (1995) apresenta quatro importantes estruturas que atuam no processo da construção do gênero e na naturalização das diferenças entre homens e mulheres em diferentes tempos e espaço. Para a teórica, essas interações humanas não são naturais, mas sim, fazem parte de um processo que se estrutura a partir de discursos, normas, instituições e subjetividade. Os discursos seriam um tipo de representação que produz efeitos sobre as interpretações das pessoas diante do gênero, como por exemplo, Eva e Maria, sendo culturalmente símbolos indicativos sobre o que é ser mulher. Desse modo, o sujeito busca se reconhecer em algumas dessas possibilidades de mulheres. Na segunda etapa, esses discursos se tornam normas a naturalizadas para serem seguidas, onde as pessoas internalizam o que é considerado normal. A partir disso, diversas instituições propagam esses discursos, símbolos e normas, como igreja, Estado, escolas, mídia e os sistemas, político, econômico e de trabalho. Ao fim desse processo, o sujeito se reconhece como esse homem ou mulher e reproduz esses significados. Para Scott, essa é a última etapa e é quando o sujeito se subjetivou dentro das normas e as enxerga como naturais. 
No campo da História, devido às desigualdades de gênero, as mulheres estiveram apagadas por muito tempo dentro de uma noção de sujeito universal, tendo sua voz e sua história silenciada por uma ciência que era sim, excludente. É nesse sentido que a história e, em grande medida, a história sobre a escravidão no Brasil remonta majoritariamente mais sobre uma história masculinista, onde as mulheres não tem protagonismo. Para Rago (1998), “as experiências das mulheres na história se diferenciavam muito das dos homens, assim [...] as mulheres trazem uma experiência histórica e cultural diferenciada da masculina, ao menos até o presente" (RAGO, 1998, p. 03). Por isso, uma abordagem feminista e de gênero é necessária para romper com a normatividade na história do homem ocidental, branco e heterossexual em uma dimensão eurocêntrica do conhecimento e nesse caso, na história da escravidão e das mulheres escravizadas no Brasil.

Para a socióloga Anna Bárbara Araújo, é preciso interseccionar gênero também com raça e ainda com classe, pois para a autora eles estão no centro das desigualdades. Desse modo, gênero, classe e raça, como categorias analíticas e com suas especificidades, estão imbricados, uma vez que as desigualdades estão relacionadas e são sentidas de modos diferentes pelas mulheres a partir desses três fatores (ARAUJO, 2018).

Nesse sentido, a partir de uma análise de gênero e raça, buscaremos dar conta de trazer visibilidade às experiências das mulheres escravizadas participantes da história, entendendo seus protagonismos e formas que construíram para resistir ao sistema escravista e em suma, ao machismo que ainda precisaram enfrentar.

\section{ESCRAVIDÃO NO SUL DE SANTA CATARINA: UMA HISTÓRIA DE}

\section{SUJEITOS ESQUECIDOS E DE MULHERES INVISIBILIZADAS}

A liberdade, na contemporaneidade é um direito bastante discutido e defendido nos mais variados aspectos que perpassam a vida humana. Ela é um princípio combinado a regras jurídicas e de convívio social que garantem ao indivíduo o direito de ir e vir, se expressar e fazer uso de seu potencial intelectual e de trabalho como melhor lhe convier, autonomia de compra e venda, com ausência de qualquer tipo de dominação, sem vir a ferir a mesma liberdade de seus pares. Estes fatores garantem a igualdade de 
todos perante a lei, entretanto, a desigualdade social e as disparidades de acesso aos direitos, por exemplo, interfere na plena liberdade individual na vida cotidiana, como é o caso das mulheres e em grande medida, das mulheres negras.

É necessário frisar que a liberdade relaciona-se com a forma de organização da sociedade em questão, em sua temporalidade, em sua definição de homem espiritual e físico, em caráter individual ou coletivo, constituindo também um conceito filosófico e abstrato. Esta noção de liberdade, que nos parece tão natural, sofreu mudanças na medida em que as sociedades humanas foram adaptando-se a novos mecanismos e estruturas sociais, filosóficas e políticas, sendo uma construção histórica de seu tempo. Contudo, o maior antagonismo à liberdade dos indivíduos que se pode citar perante tantas diversidades já mencionadas é a escravidão (SILVA; SILVA, 2012).

Tanto quanto na definição de liberdade, o conceito de escravidão também sofreu modificações de acordo com a realidade da sociedade na qual esteve ou está inserida. Têm-se notícias de escravidão desde as primeiras civilizações, entretanto, a condição de escravidão está atrelada a relações com especificidades que vão além da cor da pele, que é a mais conhecida pelo Ocidente. Faz-se importante lembrar que acima de tudo, o escravo é uma propriedade, ele não possui poder jurídico sobre sua vida, e nesse sentido justifica-se a dominação de alguns sujeitos sobre outros no viés do poder econômico. A definição mais aplicada à escravidão é um sistema que beneficia uma classe dominante com a exploração da força de trabalho de uma classe subordinada, que se renova de acordo com as necessidades, seja por perpetuação natural ou comércio. Ainda para Silva e Silva (2012), para entender a escravidão em seu contexto e em suas especificidades, é preciso entender as relações sociais, as resistências dos/as escravos/as, assim como, os conflitos que permeavam essas relações nessa instituição.

No Brasil, a escravidão tem início paralelamente a colonização dos portugueses em nosso território e se estendeu por quase três séculos. Com a carência de mão de obra para a exploração das riquezas aqui encontradas, os colonizadores fizeram primeiro uso dos indígenas nessa condição, e, posteriormente, houve uma inserção dos povos africanos escravizados que foram trazidos para cá, suprindo a necessidade crescente de trabalhadores nas lavouras de cana de açúcar no Nordeste, também na mineração e produção cafeeira no Sudeste em períodos seguintes, entre outras inúmeras atividades em que o trabalho escravo foi utilizado. Tais afirmações são bem 
conhecidas na história nacional, no que tange as regiões de ocupação mais antigas. Existe, porém, uma falsa ideia de que o sul do país não contou com a mão de obra escrava. Este equívoco se deve ao fato de que o processo de colonização e ocupação da nossa região ter se estabelecido em moldes distintos das regiões acima citadas.

O censo datado de 1872 na Província de Santa Catarina indicava 14.984 escravos/as de origem africana, o que correspondia a 9,37\% da população (PEDRO, 1988), dados que demonstram que, longe de ser desprezível, a existência de escravos/as era bem significativa, levando em consideração a precariedade das fontes disponíveis para se chegar a este percentual, ou seja, este contingente populacional negro pode ser bem mais amplo do que se tem conhecimento oficial.

Diante dessa problemática se debruçou o historiador Antônio Cézar Sprícigo em seu livro "Sujeitos esquecidos, sujeitos lembrados: Escravidão na Freguesia do Araranguá no século XIX" fruto de um estudo pioneiro numa documentação até então inexplorada na Freguesia Nossa Senhora Mãe dos Homens do Araranguá, no final do século XIX. A Freguesia que fora doada como sesmaria, se estendia territorialmente no sul do estado de Santa Catarina, desde o Rio Urussanga ao norte, limite do município de Tubarão, até o Rio Mampituba, na fronteira com o Rio Grande do Sul.

O autor analisou desde processos criminais, registros de batismos, casamentos e óbitos e 133 inventários post-mortem registrados entre 1840 e 1900, que continham aproximadamente 430 propriedades utilizadas nas atividades pecuária, agrícola e extração de madeira, dentre outras. Destes documentos, encontrou a posse de escravos em 31\% dos casos. Dados populacionais encontrados de 1866, também apontam que $25 \%$ das pessoas que aqui viviam na Freguesia do Araranguá eram escravas. De acordo com Sprícigo:

A presença de imigrantes europeus (principalmente alemães e italianos) foi de certa forma responsável, juntamente com o discurso historiográfico produzido, pela constante afirmação da quase total ausência de escravos negros no Sul do Estado de Santa Catarina. Afirmar que a presença negra em Santa Catarina ocorreu desde o início de seu povoamento é muito diferente do que se afirmar que na Bahia a presença negra data dos primórdios da colonização. Essa ideia gera desconfiança, pois o Estado de Santa Catarina é marcadamente reconhecido como terra de alemães e italianos. Além disso, o discurso produzido em terras catarinenses sempre foi de origem branca que vende a imagem de 'mini Europa brasileira'. (SPRÍ́CIGO, 2007, p. 113). 
Portanto, não se justifica com números a maior ou menor participação do nosso estado no sistema de exploração da mão de obra escrava. Todavia, as características que mais contribuíram para diferenciar Santa Catarina dos demais estados no quesito numérico são o fato de as propriedades serem menores, onde os donos, em alguns casos, até trabalhavam juntamente com os escravos que possuíam em suas atividades, bem como as habitações de pouco valor, e geralmente, a única da família inventariada, que sustentam a tese de não existência de senzalas no estilo pavilhão na Freguesia do Araranguá, habitações estas facilmente encontradas em alguns estados do nordeste e sudeste. A média de cinco escravos por propriedade na Freguesia era verdadeiramente menor se comparada a outras regiões, contudo, os inventários citam, por exemplo, Marcelino Teixeira de Souza, que tinha posse de 31 escravos. Mais que uma mera exceção à regra, este caso demonstra a instituição do sistema escravagista no estado, não podendo de forma alguma cair às margens da insignificância, mesmo que tenha ocorrido com menor intensidade.

É importante ressaltar que a invisibilidade desses sujeitos escravizados e em grande medida das mulheres nessa situação na história catarinense não dá a eles e a elas os créditos de participação efetiva na formação de Santa Catarina, tanto econômica e socialmente, quanto na miscigenação da população e na cultura local, reforçando o discurso de que o catarinense tem sua identidade arrimada na colonização europeia. Caracterizar o contingente populacional do estado de forma tão homogênea torna-se bastante excludente se considerarmos a diversidade de povos que já habitavam a região e outras populações que aqui se instalaram além dos alemães e italianos.

Se à população negra em geral é dada pouca visibilidade, as mulheres, nesse contexto, têm sua existência ainda mais encoberta e invisibilizada. Conforme Bell Hooks (2019) que analisa o caso da escravidão estadunidense, "o sexismo era parte integrante da ordem social e política trazida de terras europeias por colonizadores brancos" (HOOKS, 2019, p. 37), pois para a mulher escravizada havia ainda esse forte peso do sexismo, que reforçava seu status de mulher e escrava em um sistema escravista e patriarcal.

Em análise retrospectiva da experiência da mulher negra escravizada, sexismo revela-se tão forte quanto o racismo como força opressiva na 
vida das mulheres negras, sexismo institucionalizado - ou seja, patriarcado [...] (HOOKS, 2019, p. 37).

Conforme a análise da autora, o fato de serem escravas mulheres, com frequência as delegava a um lugar ainda mais subalterno nesse sistema já tão violento, como "um lembrete de sua vulnerabilidade sexual, o estupro era um método comum de tortura usado pelos escravizadores" (HOOKS, 2019, p. 41) o que demonstra um forte sexismo alinhado a diversas formas de violência baseadas no gênero.

No sistema de trabalho escravo, preferencialmente, os homens eram utilizados nos trabalhos de lavoura, pois as tarefas eram mais árduas e exigiam maior força física, mas isso não limitava as mulheres exclusivamente ao serviço doméstico, o que para Hooks (2019) demonstra outras diversas formas de exploração do trabalho escravizado feminino.

A área que com mais clareza revela a diferença entre o status do homem escravizado e o da mulher escravizada é o trabalho. O homem negro escravizado foi primordialmente explorado como trabalhador do campo; a mulher negra foi explorada como trabalhadora do campo, em atividades domésticas, como reprodutora e como objeto para o assédio sexual perpetrado pelo homem branco. (HOOKS, 2019, p. 47).

Mesmo o tráfico negreiro sendo em maior quantidade de homens, com o passar do tempo, a reprodução natural e a inserção do trabalho feminino em toda e qualquer função, foi igualando numericamente a população e os preços para a obtenção de escravos de ambos os sexos no Brasil. No caso catarinense, as mulheres trabalharam na exploração baleeira e no comercio em geral na região da ilha, porém na Freguesia, não havendo comércio na época, as atividades eram mais localizadas no âmbito rural.

Nas fontes examinadas por Sprícigo (2007), a mão de obra feminina era empregada como lavadeiras, cozinheiras e também roceiras, como no registro de 1873, entre os bens inventariados de Manoel Pereira da Rocha, a presença de cinco escravos, destes três homens e duas mulheres, todos atribuídos ao trabalho de lavradores. Já nos registros de Ludovina Roza de Jesus, em 1880, havia oito escravos, seis homens como lavradores e duas mulheres como costureiras. Outro fator que fez o trabalho das mulheres nivelar-se em importância ao dos homens eram os ofícios por elas desempenhados, como costureiras e tecedeiras, habilidades de grande valia aos proprietários, já que não se fazia indispensável importar tecidos e vestuário para os 
escravos e seus senhores, além dos objetos de palha para o uso doméstico e na lida das lavouras, fabricados artesanalmente. A compra de tais produtos era descomedidamente cara, pela demanda e pelo transporte necessário para chegar ao consumidor.

Desta feita, Sprícigo (2007) expõe a existência de uma escrava por nome Bibiana e sua filha Engrácia, que pertenceram a Manoel Pereira Mello, que residiu nos Conventos. Relata-se dela muita aptidão, e além da filha ser sua auxiliar (e provavelmente sucessora no trabalho), o filho Brígido também tinha o ofício de sapateiro, o que lhe permitiu comprar sua liberdade aos 17 anos de idade, por 800 mil réis. Vê-se nas entrelinhas deste caso a probabilidade de haver existido certa hierarquia entre os escravos devido a funções especificas, que poderiam dar-lhes certos privilégios, por assim dizer.

A autora Maria Lúcia de Barros Mott em sua obra "Submissão e Resistência: $A$ mulher na luta contra a escravidão" tem como cenário o Brasil colonial e busca demonstrar a participação feminina na história brasileira, expondo ocorrências relacionadas às mulheres que foram silenciadas pela historiografia tradicional, nas mais variadas posições sociais e temporais, desde mulheres administradoras de capitanias hereditárias, participando das expedições bandeirantes (quer acompanhando os maridos, quer sendo líderes de tais), até as formas mais sutis ou violentas de resistência das escravas na luta por sobrevivência e liberdade, sobre o que ainda falaremos mais adiante. Ela traz a tona essa questão, afirmando que as escravas domésticas apesar de serem mais vigiadas e suscetíveis a sofrer violência sexual, tinham uma mais elevada qualidade de vida, comparadas aos demais escravos.

Os privilégios usufruídos pelas escravas domésticas nas casas ricas foram mencionados por vários autores: desfrutavam de melhor moradia [...], tinham acesso a uma alimentação diferenciada, vestiamse melhor (menos pela necessidade da escrava do que pelo reflexo do status do seu senhor), aprendiam mais facilmente um ofício e até mesmo a ler e escrever (o que era proibido). Tinham ainda chances de saber o que estava acontecendo fora dos limites da casa, do engenho ou da fazenda, devido ao fato de ouvirem as conversas de seus senhores e servirem os hóspedes e os visitantes, obtendo assim informações nada desprezíveis na hora de comprar a alforria. (MOTT, 1988, p. 22). 
No enfoque de Santa Catarina, o livro "História diversa: Africanos $e$ afrodescendentes na ilha de Santa Catarina", alguns episódios reafirmam as relações diferenciadas para alguns escravos junto aos seus senhores. A obra conta em seu primeiro capítulo de autoria de Beatriz Gallotti Mamigonian e Vítor Hugo Bastos Cardoso a trajetória de Antonio e Joaquina, de origem atribuída a "Guiné", que foram os primeiros escravos comprados por Manuel Fernandes Lessa e sua esposa Maria Madalena, por volta de 1790, em Desterro. O casal teve cinco filhos, nascidos a partir de 1794, três meninas por nome Benedita, Genoveva e Maria, e dois meninos que receberam o nome de Francisco (pela ocasião da morte de um deles, provavelmente ainda bebê) que nasceram em condição escrava, porém que receberam a liberdade sendo ainda crianças, em 1805. Não se sabe ao certo sob que condições, tendo em vista que os padrinhos de todas as crianças eram homens livres, que costumavam na época auxiliar os pais na árdua tarefa de alforriar os afilhados, quando seus proprietários estipulavam um valor a liberdade. Consta nos registros de batismo que a próxima filha do casal, Francisca, foi liberta no recebimento do sacramento católico, em 1807, desta vez, pela vontade dos senhores. Os autores expõem ainda que, em 1810, o casal Antonio e Joaquina exercia certa liderança sobre os 10 cativos adultos que foram incorporados à propriedade de Lessa, organizando os trabalhos que caberiam para cada qual, porém, só receberam a liberdade das mãos da viúva Maria Madalena da Silva, em 1811.

O capítulo sete da mesma obra, de autoria de Fabiane Poponigis, apresenta uma escrava chamada Maria Mina, que teve seu registro de alforria concedido em 1860 por Luis de Santa Anna Carpes, por oitocentos mil réis. Maria era quitandeira, consta que possuía habilidade em suas negociações comerciais e trabalhava em um vão alugado na Praça do Mercado de Desterro. Cerca de 20 anos depois, Maria compra a liberdade de um sobrinho, Manoel, de 24 anos, por novecentos mil réis, num acordo que estabelecia parcelas a serem quitadas posteriormente. Não sendo cumprido o pagamento, cogitouse não haver parentesco entre os dois e revelou a prática de ex-escravos comprarem escravos para ensinarem seus ofícios, numa relação não muito clara, mas que mantém uma dependência entre as partes. Os dois casos dão-nos um parecer favorável a uma mobilidade social cerceada e difícil para os escravos e escravas, mas não impossível.

Embora a maciça maioria da população escravizada em Santa Catarina tenha passado a vida toda nesta condição, não significa que pequenos ou grandes atos de 
resistência não tenham havido na esfera da vida cotidiana. Desde a lentidão no trabalho, as fugas e até mesmo o suicídio eram armas utilizadas para dar prejuízos aos senhores. No plantel do senhor de escravos Marcelino Teixeira de Souza, domiciliado em Urussanga Velha, Sprícigo (2007) fez um levantamento de um total de 31 escravos. Nada de tão anormal a não ser pelo fato de que apenas 7 escravas deram a luz a 25 escravos, dentre elas Quitéria, com 6 filhos, e Infância, que teve 10, dos quais 4 já haviam sido libertos em 1879, quando, em um processo judicial contra seu proprietário, tenta comprar sua liberdade por 400 mil réis. Uma das alegações defendidas pela escrava Infância é que havia dado muitos frutos de seu trabalho e vida para seu proprietário, o que atribuía à maternidade das negras uma forma de lucro ao seu dono. No caso das mulheres, os filhos poderiam ser peça de barganha, tanto quanto o aborto e o infanticídio poderiam ser atos de rebeldia contra o sistema escravocrata.

Chamou a atenção do autor que, opostamente, a resistência de Marcelino em conceder a liberdade a sua escrava Infância, o testamento de dona Joaquina Rosa de Jesus, especificou 4 mil réis de herança para a preta Maria Conga. Também declara ter deixado em liberdade a escrava Simiana, bem como um tear, uma panela de ferro e terras. O registro de casos tão diferenciados caracteriza o sistema escravocrata mais flexível do que se imagina. As relações humanas entre escravas e seus donos eram variantes e distinguiam-se entre si.

A conquista da liberdade era o objetivo maior a ser alcançado durante a vida. Requeria dos escravos a elaboração de boas estratégias que resultassem nesse fim. Anos de cativeiro com o auxílio a sua senhora, presença constante na ausência de familiares, lida ao trabalho doméstico e da roça. Estratégias que lhe renderam a liberdade e a possibilidade de planejar o momento certo de ter seus filhos, terra para começar a vida como pessoas livres, um tear e uma panela. (SPRÍCIGO, 2007, p. 161).

A análise das fontes sobre o assunto aponta para dois caminhos inversamente opostos na luta que estas mulheres se propunham pela liberdade. O primeiro, a tática de bons serviços prestados, especialização através dos ofícios tão úteis aos proprietários, uma forma de aproximação que poderia resultar em ganhos em dinheiro para as cativas e permitir assim a compra de sua alforria ou um relacionamento mais favorável para sua libertação consentida. Maria Lúcia Mott afirma que algumas cativas valiam-se inclusive da sexualidade. A sedução do senhor teria sido utilizada na luta 
particular entre a senhora e a escrava, assim como para obter benefícios imediatos (MOTT, 1988).

O segundo caminho pra tal empreitada está no bojo da resistência não velada, aversão ao cativeiro, à exploração sexual e ao trabalho forçado. A luta declarada pela liberdade que Ihes fora retirada, neste caso, se fazia de todas as maneiras que se possa imaginar. As mulheres cativas praticavam o aborto e infanticídio frequentemente. Podemos elencar algumas razões: a gravidez poderia ser consequência de um estupro; o risco que envolvia uma gravidez e parto na época; o prejuízo que dariam ao senhor, não acrescentando uma peça ao seu plantel, principalmente após a Lei Euzébio de Queiroz, de 1850, que proibia o tráfico negreiro, fazendo da reprodução dos escravos uma alternativa para obter mais trabalhadores para suas propriedades; a questão da maternidade sem a sustentação social, ou seja, trazer ao mundo uma criança que viveria nas mesmas condições que ela não parecia apropriada, pelo contrário, poderia sentir que não permitiu a outro ser humano viver em situação tão deplorável como a sua.

No mesmo viés, o suicídio se enquadra. A ideia de causar danos ao patrimônio de seu dono aliada ao desejo de sair do cativeiro, fazia do ato de tirar a própria vida bastante tentador, ao ponto de muitos o terem feito. Como também não eram raras as fugas, mesmo com o risco de serem capturadas e castigadas se não obtivessem sucesso, não fazer o serviço doméstico de forma correta e até a tentativa de envenenamento dos proprietários podem ser apontados como estratégias de resistência ao sistema escravocrata que as explorava.

Outra especificidade que chama a atenção nos estudos de Sprícigo (2007) é o surgimento de uma nova modalidade de resistência na Freguesia como uma forma de se livrar da situação e do status de escravo ou escrava:

Quando encontrei alguns processos de arbitramento, que determinavam o valor a ser pago pelo escravo pela compra de sua liberdade, me dei conta de que já era possível trazer do passado os escravos, não apenas como números e elementos estatísticos, mas como agentes históricos, que trabalhavam, sofriam, lutavam, resistiam e morriam, desfazendo a ideia de que, pela menor quantidade de escravos, esses acontecimentos não fossem comuns a Freguesia do Araranguá, ocorrendo apenas nas grandes áreas de escravidão no Brasil. (SPRÍCIGO, 2007, p. 181). 
Como a lei de 1871 permite ao cativo comprar sua liberdade a despeito do interesse ou não de seu senhor, os processos judiciais nesse desígnio aparecem. $\mathrm{O}$ autor cita vários personagens usando de argumentos, suas relações sociais e os recursos financeiros angariados em toda uma vida de trabalho buscando serem livres.

\section{CONSIDERAÇÕES FINAIS}

Não se pode generalizar a situação de negras e negros cativos no Brasil, em Santa Catarina e em específico na Freguesia do Araranguá como estática e uniforme. Ao contrário, cabe ao/a historiador/a contextualizar com elementos de cunho social, cultural e econômico que cabiam à condição escrava em cada uma destas esferas. E não se pode prestar menor importância aos feitios de resistência a que estes sujeitos aderiram tentando conquistar nem que fossem pequenas liberdades, porque embora 0 sistema escravocrata tenha seu conceito instituído como dominação de uns sobre outros, as relações interpessoais entre estes sujeitos pode ter variações que jamais alcançaremos somente com as fontes que temos a nossa disposição, sendo que toda a plenitude que rege a vida cotidiana de sociedades do passado foge aos documentos oficiais. Contudo, a liberdade conferida aos/as escravos/as pela Lei Áurea, em 1888, não impediu que reverberassem todas as privações dessa população escravizada no Brasil no contorno de preconceito racial tão presente na contemporaneidade.

Por essa razão, este trabalho buscou dar visibilidade e nomes a estas personagens, que subordinadas a toda opressão, incluindo o peso do sexismo para as mulheres, inauguraram essa luta. As medidas institucionais exercitadas no Brasil durante quase 300 anos de escravidão, podem ser vistas na discriminação e violência de gênero, vivenciadas por mulheres negras nos dias atuais, pois elas são a representação do "outro" perante a branquitude e a masculinidade, que se colocam em posição superior e privilegiada diante delas. Para Hooks, em suma, a escravidão representou para as mulheres vivências diferentes e com um peso de sofrimento ainda maior.

Apesar de isso de maneira alguma diminuir o sofrimento de homens negros escravizados e a opressão contra eles, é óbvio que as duas forças, sexismo e racismo, intensificaram e aumentaram os sofrimentos das mulheres negras e a opressão contra elas. (HOOKS, 2019, p. 47). 
A dupla discriminação imposta decorre, inclusive, uma ideia da incapacidade intelectual, haja vista que surpreende uma mulher ocupar cargos de liderança e destaque, porém, se esta mulher for negra, essa atribuição é tida como ainda mais extraordinária. Aí se encontra mais força para que estas mulheres saiam das sombras de uma sociedade machista, patriarcal e racista. As estratégias podem se modificar, mas a resistência para que haja igualdade entre brancos, negros, brancas e negras, precisa continuar até ser alcançada efetivamente na sociedade brasileira e catarinense.

\section{REFERÊNCIAS}

ARAUJO, Anna B. Da Ética do Cuidado à Interseccionalidade: Caminhos e Desafios para a Compreensão do Trabalho de Cuidado. In Dossiê Gênero Cuidado e Famílias. Mediações, Londrina, V. 23 N. 3, P.43-69, DEZ. 2018.

HOOKS, Bell. E eu não sou uma mulher? : mulheres negras e feminismo / bell hooks ; tradução Bhuvi Libanio. - 1a ed. - Rio de Janeiro: Rosa dos Tempos, 2019.

KUAMOTO, F.; LOSNAK, C.J. A mulher retratada pelo Jornal Folha da Manhã - 1925-30. In Intercom - Sociedade Brasileira de Estudos Interdisciplinares da Comunicação. Rio de Janeiro, 2015.

MAESTRI FILHO, Mário. A servidão negra. Porto Alegre: Mercado Aberto, 1988.

MAMIGONIAN, Beatriz Gallotti; VIDAL, Joseane Zimmermann (Orgs.). História Diversa: Africanos e Afrodescendentes na ilha de Santa Catarina. Florianópolis: Ed. Da UFSC, 2013.

MOTT, Maria Lucia de Barros. Submissão e Resistência: a mulher na luta contra a escravidão. São Paulo: Contexto, 1988.

PEDRO, Joana Maria (Org.). Negro em terra de branco: escravidão e preconceito em Santa Catarina no século XIX. Porto Alegre: Mercado Aberto, 1988.

RAGO, Margareth. Epistemologia feminista, gênero e história. In. Pedro, Joana, Grossi, Miriam (orgs) - Masculino, Feminino, Plural. Florianópolis: Ed. Mulheres, 1998.

SCOTT, Joan. Gênero: uma categoria útil de análise histórica. Educação e realidade. Porto Alegre, v. 20, 2, p. 71-99, jul/dez, 1995.

SILVA, Kalina Vanderlei. Dicionário de conceitos históricos / Kalina Vanderlei Silva, Maciel Henrique Silva. - 2. Ed. - São Paulo: Contexto, 2006. 
SPRÍCIGO, Antônio Cézar. Sujeitos Esquecidos, Sujeitos Lembrados: Entre fatos e números, a escravidão registrada na Freguesia do Araranguá no século XIX. Caxias do Sul: Murialdo, 2007. 


\title{
CAPÍtULO IV
}

\section{VIOLÊNCIA DOMÉSTICA: UM ESTUDO ACERCA DA VIOLÊNCIA VIVIDA NA INTIMIDADE DO ESPAÇO PRIVADO}

\author{
Carola Jorge Riffel ${ }^{1}$ \\ Rafael Oliveira Morel Lopes ${ }^{2}$ \\ Juliana Fernandes ${ }^{3}$
}

\footnotetext{
${ }^{1}$ Psicóloga - Universidade de Fortaleza/UNIFOR

${ }^{2}$ Psicólogo - Universidade de Fortaleza/UNIFOR

${ }^{3}$ Psicóloga, Professora Universitária - Universidade de Fortaleza/UNIFOR (professora orientadora)
}

\section{RESUMO}

A violência contra a mulher ainda é preocupante. Mesmo existindo ações e leis que protejam essas mulheres, poucas são as que têm coragem de denunciar, permanecendo em silêncio. Sendo um assunto bastante atual, a violência contra as mulheres é um que ato que permanece em evidência na sociedade contemporânea e elas continuam a sofrer tanto fisicamente como psicologicamente. Ponderamos, no entanto, que as motivações que impedem as denúncias se dão nas práticas do cotidiano vividas, muitas vezes, na intimidade familiar, embora também fora dela, pois existe o medo, a vergonha, a dependência financeira e a crença de que o marido pode mudar. Então, a escolha pela denúncia representa um processo que essa mulher precisa vivenciar até sentir-se pronta e segura para realizar. O presente trabalho tem como proposta realizar um estudo sobre a violência doméstica contra a mulher, enfatizando os motivos que levam as mulheres a não realizar a denúncia de seu agressor. Para a realização da pesquisa, foi utilizado o estudo bibliográfico para um maior aprofundamento sobre o tema.

Palavras-chave: Violência doméstica. Mulheres. Denúncias.

\section{INTRODUÇÃO}

A escolha pelo tema surge devido aos pesquisadores estarem interessados em um aprofundamento com relação ao tema, uma vez que, a violência doméstica ainda é muito presente. Movidos pelo interesse em saber os motivos que fazem com que a mulher não consiga denunciar seu agressor e reconhecendo que elas convivem com um 
sofrimento enorme que as paralisa, buscou-se ampliar a compreensão sobre essa relação e qual o contexto no qual ela está inserida. Com isso, o interesse pelo assunto foi crescendo e percebeu-se que estudar e pesquisar sobre esse tema proporcionaria uma abrangência de conhecimento para a carreira profissional, além de auxiliar na compreensão e atuação dos casos de violência.

A existência da violência na vida das mulheres representa um período de crueldade para estas que sofrem agressões de seus companheiros, maridos ou até mesmo namorados. Porém, esse intervalo pode ter um fim trágico, dependendo da intensidade da agressão, pois a mulher pode acabar morrendo (SABINO, 2014).

A violência contra a mulher tem sido algo bastante pesquisado na contemporaneidade, devido ao grande índice de mulheres que vivenciaram ou vivenciam essa experiência ocorrida muitas vezes dentro da própria casa.

Com uma intensa carga de sofrimento psíquico, muitas mulheres suportam a dor de serem agredidas, em grande parte por seus parceiros, e começam a travar uma luta não só contra o agressor, mas contra si mesmas, seus medos, incertezas e inseguranças. Segundo Soares (2005), a violência emocional que essas mulheres sofrem vai muito além da ameaça física, pois se manifesta também através das humilhações e intimidações sofridas, fazendo com que a mulher se sinta mal consigo mesma e traga um sentimento de culpa e incapacidade, evidenciando, assim, um sofrimento não só físico, mas psíquico.

Estudos sobre as mulheres vítimas de violência, realizados em diferentes países da América Latina, indicam que um considerável número de mulheres já foram vítimas de violência física por parte de seus parceiros. O percentual de mulheres agredidas fisicamente por um homem chegou a uma máxima de $50 \%$ em alguns países, o que quer dizer que metade das mulheres participantes da pesquisa já foram, em algum momento da vida, vítimas de violência física por um homem. Este dado corresponde a um índice alarmante e preocupante, que chama a atenção para que esses fatos sejam melhor compreendidos e investigados (Secretaria Especial de Políticas para as Mulheres, 2003).

Ao observar as porcentagens das constatações das violências, compreende-se que sofrer um ato de violência tem deixado, aos poucos, de ser visto e combatido como um grave atentado contra os direitos e contra integridade do ser humano, uma vez que ele se torna algo bastante comum entre as mulheres na sociedade atual. No entanto, 
não se pode correr o risco de chegar a uma violência naturalizada, vista como algo aceitável, comum e normal. É necessário investigar os fatos e buscar compreender onde estão as raízes do problema, para que assim se possa buscar uma solução eficaz.

Segundo a Constituição Federal brasileira, é dever do Estado assegurar assistência e proteção a todos os integrantes de uma família, uma vez que esta é considerada a base da sociedade. Conforme artigo 226 da Constituição, § 8:. "O Estado assegurará a assistência à família na pessoa de cada um dos que a integram, criando mecanismos para coibir a violência no âmbito de suas relações" (DIAS, 2008, p. 27).Sendo assim, a violência doméstica contra a mulher representa sim uma violação dos direitos humanos garantidos pelo Estado, cabendo a ele resguardar essas mulheres de todo forma de negligência, discriminação, exploração, crueldade e opressão (DIAS, 2008).

A mulher tem, portanto, o direito a proteção que, ao ser violado, implica que o/a perpetrador/a está sujeito à ação punitiva da Lei. No intuito de garantir à mulher o pleno exercício de seus direitos, criou-se a Lei Maria da Penha, com o objetivo de punir os agressores e deixar claro que não se deve admitir mais a violência praticada nas relações domésticas e familiares.

Reiteramos a importância da Lei Maria da Penha para o enfrentamento à violência de gênero e a efetiva proteção das mulheres em situação de violência doméstica. Contudo, após inspeção em quase todo o País, constatamos que ela ainda não é plenamente aplicada no Brasil: em algumas capitais e sobretudo no interior, os operadores jurídicos continuam aplicando a lei conforme lhes convém fazendo uso de instrumentos ultrapassados e já proibidos pelo Supremo Tribunal Federal (STF), como os institutos despenalizadores da Lei $\mathrm{n}$ - 9.099, de 26 de setembro de 1995, entre os quais se destaca a suspensão condicional do processo (COMISSÃO PARLAMENTAR MISTA DE INQUÉRITO, 2013, p. 9).

Diante disso, compreende-se que a lei de proteção à mulher em caso de violência doméstica já existe, porém ela não é plenamente aplicada no Brasil, porque utiliza ainda meios ultrapassados para o registro dos casos de denúncia, chegando a suspender o caso e arquivá-lo.

Várias são as questões que perpassam essas mulheres vítimas de violência doméstica, influenciando a sua forma de agir e pensar a sua própria realidade. Com isso, 
muitos são os motivos que as impedem de sair da situação na qual elas se encontram, fazendo com que muitas não consigam denunciar o seu agressor.

Em pesquisa realizada pela Fundação Perseu Abramo em 2010 com relação à violência contra a mulher, contatou-se que $55,7 \%$ das vítimas de agressão não procuraram a polícia. Dentre as razões apresentadas, 33,1\% afirmaram que tinham medo de represália ou não queriam envolver a polícia em suas fragilidades pessoais. $\mathrm{Na}$ mesma pesquisa, algumas mulheres relataram que procuraram a polícia, mas não realizaram o registro e apontaram como motivos: $22,4 \%$ a polícia não querer fazer 0 registro, $19,2 \%$ o medo de represália ou não querer envolver a polícia, 10,3\% a falta de provas e 10,2 \% não acreditavam na polícia (Comissão Parlamentar Mista de Inquérito, 2013).

Deste modo, percebe-se a dificuldade de realizar a denúncia por diversos motivos, já que elas vivem um sofrimento dentro da própria casa e não conseguem se libertar. Uma dor que pode ser tanto física como psicológica, como se estivesse em um ciclo de violência do qual não consegue sair.

O ciclo da violência é composto de três fases, que são: a construção da tensão no relacionamento, a explosão da violência (descontrole e destruição) e a lua-de-mel (arrependimento do/a agressor/a). Na primeira fase, acontecem os primeiros indícios de uma agressão, por meio de gritos, ameaças, ciúmes e a vítima sempre tenta acalmar seu agressor, acreditando que a raiva vai passar logo e se sente responsável pelos atos, negando sua própria raiva e assumindo a culpa (SOARES, 2005).

Na segunda fase, as agressões já são mais agudas. É quando se atinge a tensão mais alta e os ataques são mais graves. A relação se torna descontrolada sem uma administração. Já na terceira fase, ocorre o término da violência doméstica, pois o agressor demonstra remorso e medo de perder a companhia e faz promessas e juramentos de que não irá mais cometer os atos violentos, entrega presentes, voltando a ser a pessoa apaixonada como antes (SOARES, 2005).

Essas fases demonstram um ciclo no qual a mulher violentada se insere, tendo um início e um fim, mas um final que pode recomeçar, pois, muitas vezes, é impossível controlar o ato violento. Assim, essas mulheres acabam por viverem dessa forma e não conseguem mais sair, sentindo-se aprisionadas nesse ciclo. No entanto, mesmo 
existindo cuidados de proteção para a mulher, é preciso mais ações de defesa, haja vista que a violência contra a mulher é uma urgência nacional.

Com isso, percebe-se como essas mulheres se tornam vulneráveis no contexto da violência, vivendo em um ambiente que não proporciona harmonia, felicidade e companheirismo, mas em um lugar de medo, dor e agressões, que, muitas vezes, pode resultarem morte. Vale destacar que "em geral as mulheres de baixa renda tendem a denunciar mais, enquanto que as mulheres das classes média e alta tendem a evitar esse tipo de exposição" (Secretaria Especial de Políticas para as Mulheres, 2003, p. 11).

Segundo uma pesquisa realizada em 2013 na cidade de São Paulo, sobre a Percepção da Sociedade sobre a Violência e Assassinatos de Mulheres, observou-se que a violência ataca mulheres de todas as classes sociais, embora se possa identificar que a maior parte das denúncias são realizadas por mulheres de classe social mais baixa.

Para a ministra da Presidência da República, Eleonora Menicucci, da Secretaria de Políticas para as Mulheres, conforme reportagem divulgada em Agosto de 2013, essa pesquisa retrata que, por mais que a violência contra a mulher atualmente perpasse todas as classes sociais, a dor das mulheres mais pobres é mais vista do que a das mulheres de poder aquisitivo mais elevado. Isto acontece porque as mulheres mais pobres se expõem mais facilmente, colocam os seus rostos na mídia e denunciam com mais veemência, uma vez que dependem das políticas públicas e dos serviços públicos (ALBUQUERQUE, 2013).

Observa-se, portanto, que as mulheres mais pobres terminam por serem mais dispostas a denunciar, pois se preocupam menos com a aparência, com a opinião pública e com os julgamentos das pessoas.

Compreende-se que a mulher ainda sofre agressões e que poucas denunciam tal ato, e que a não denúncia pode resultar em consequências irreparáveis. Portanto, o silêncio dessas mulheres com relação ao ato violento é uma questão a se pensar, pois, para que a justiça seja realizada, é necessário que tais mulheres tenham coragem para denunciar.

Outro dado importante a destacar é que, segundo o mapa da violência de 2012, as agressões contra as mulheres ocorrem em maior número por meio da força ou espancamento, correspondendo a $56 \%$ das situações de vitimizações, e que os pais são os principais responsáveis pelo ato violento até os 14 anos de idade da vítima. O papel 
paterno, portanto, vai sendo substituído pelo novo cônjuge ou namorado (WAISELFISZ, 2011).

O tema da violência doméstica, mesmo sendo bastante discutido pelos mais variados autores, como Blay (2003), Trindade (2008), Dias (2008), Minayo (2005), Casique (2006), Soares (2005), Osterne (2011), dentre outros, ainda existem muitas mulheres em situações de risco e vulnerabilidade, como o medo de realizar a denúncia devido aos mais diversos fatores que as impedem, mesmo existindo uma lei que as protege. Deste modo, a pesquisa busca compreender os possíveis fatores que possam influenciar as mulheres vítimas de violência doméstica a permanecerem nessa situação.

Para tanto, a presente pesquisa tem como objetivo geral compreender a violência doméstica contra a mulher no contexto familiar e os possíveis motivos que as influenciam a não denunciar. Diante desse objetivo, a pesquisa se propõe a discutir a violência doméstica contra a mulher, identificar as principais causas da ausência de denúncia das vítimas e perceber o desenvolvimento das relações familiares em contextos de vulnerabilidades sociais.

\section{METODOLOGIA}

A pesquisa desenvolvida será por meio da abordagem qualitativa e revisão bibliográfica. Assim, a coleta de dados ocorrerá por meio de livros, artigos científicos presentes na base de dados da SCIELO, revistas que abordam o tema, dentre outras bases, para que se possa compreender os verdadeiros motivos e fatores que possam estar influenciando a permanência da mulher na relação de violência doméstica, levando-a a não denunciarem seu agressor.

Para Gil (2008), em uma coleta de dados bibliográficos, o trabalho se desenvolve por meio de materiais já elaborados, tendo como vantagem permitir ao pesquisador uma cobertura de uma gama de fenômenos.

Segundo Trocoli e Santos (2005), a “pesquisa teórica tem como propósito desvendar conceitos, mediante um diálogo no plano do pensamento com autor(es) acerca de determinadas teorias e/ou conceitos específicos"(p. 4).Dessa forma, essa pesquisa busca uma interligação de estudos de diversos autores sobre o tema proposto, auxiliando cada vez mais na sua compreensão.

Por tratar-se também de uma pesquisa qualitativa, que se propõe a estudar 
aspectos mais subjetivos, diferente da pesquisa quantitativa que visa aspectos mais objetivos e mensuráveis, entende-se que a pesquisa qualitativa busca um maior aprofundamento sobre o assunto pesquisado, não se limitando a dados numéricos e estatísticos. Portanto, segundo Trocoli e Santos (2005),

A pesquisa quantitativa e a pesquisa qualitativa exigem atitudes e procedimentos específicos para cada uma dessas modalidades, diferenciando-se não só quanto à finalidade, mas também quanto à metodologia (na escolha dos métodos de análise, das técnicas e instrumentos de coleta, na forma de interagir com o fenômeno investigado) (p. 6).

Para Bastos (2007), “a pesquisa bibliográfica possibilita a análise comparativa de várias posições acerca de um problema, a partir das quais o pesquisador defenderá sua tese" (p. 32). Faz-se necessário, portanto, uma articulação entre os conceitos e teorias de um ou mais autores com o intuito de fundamentar o estudo e a relevância da pesquisa, buscando uma forma diferenciada de se pensar o assunto problematizado, a partir da intercessão do pensamento dos mesmos.

\subsection{Violência Doméstica: Revisando Paradigmas}

Pesquisar sobre a violência doméstica contra a mulher remete incialmente ao conceito de violência, pois, segundo Odálio (2004), a violência já está entranhada no diaa-dia das pessoas e pensar e agir em função dela se transformou em um modo de ver e de viver o mundo do homem. Isso porque, nos dias atuais, a violência está muito presente no cotidiano, pois se presencia os mais variados tipos de agressão do homem contra o próprio homem. Está mais difícil de se pensar antes de agir, como se a reação já fizesse parte da rotina de todos. Porém essas reações podem ter consequências graves.

Contudo, quando falo em violência, ou quando nós falamos e nos preocupamos com a violência, sua primeira imagem, sua face mais imediata e sensível, é a que se exprime pela agressão. Agressão física que atinge diretamente o homem tanto naquilo que possui, seu corpo, seus bens, quanto naquilo que mais ama, seus amigos, sua família (ODÁLIO, 2004, p. 9).

O homem passa a ser agredido em todos os seus aspectos e na sua vida cotidiana, ocorrendo uma violação dos seus direitos. Vive-se com medo do que o outro pode fazer, das suas reações e dos seus atos. Para Casique e Furegato (2006), "a violência é mutante, 
pois sofre a influência de épocas, locais, circunstâncias e realidades muito diferentes" (p. 2). No entanto, entende-se com isso que a violência já faz parte do ser humano desde os primórdios e hoje já virou uma ação constante, na qual muitos sofrem esses atos, podendo destacar as mulheres como as principais vítimas.

É importante compreender melhor a violência de gênero para que assim se possa chegar à violência doméstica contra a mulher.

Para se entender a denominação de violência de gênero é preciso ter em conta o carater social dos traços atribuidos a homens e mulheres. Dessa forma, observa-se que a maioria dos traços do feminino e do masculino são construções culturais, são produtos da sociedade e não derivados necessariamente da natureza (CASIQUE E FUREGATO, 2006, p. 2).

Casique e Furegato (2006) relatam sobre a violência de gênero ser aquela que ocorre entre o homem e a mulher que, de forma mais específica, pode ser aquela em que o homem exerce o ato e a mulher sobre a agressão. $O$ homem como um ser ativo na relação, e a mulher como um sujeito passivo, que obedece a ordens, fazendo o que esse homem deseja.

A violência de gênero é aquela exercida pelos homens contra as mulheres, em que o gênero do agressor e o da vítima estão intimamente unidos à explicação desta violência. Dessa forma, afeta as mulheres pelo simples fato de serem deste sexo, ou seja, é a violência perpetrada pelos homens, mantendo o controle e o domínio sobre as mulheres (CASIQUE, FUREGATO, 2006, p. 2).

Compreende-se que essa violência de gênero remete às desigualdades entre homens e mulheres pois, muitas vezes, o homem é quem manda e a mulher é quem deve obedecer. Esse homem, no seu lugar de autoridade, pode, às vezes, perder o controle e exercer um ato violento contra a mulher, que acaba sofrendo danos físicos.

Porém, diante do que esses autores comentam, entende-se que essa violência de gênero é muito mais complexa, uma vez que também a violência de gênero perpassa vários contextos e pode ser exercida pela mulher contra o homem, além da violência contra homossexuais, dentro outros tipos. Neste sentido,

a violência, em suas formas destrutivas, visa o outro para destruí-lo, mas atinge a humanidade como um todo. Este fenômeno é uma herança comum, historicamente, a todas as classes sociais, culturas e sociedades e, portanto, um fenômeno intrínseco ao processo civilizatório, constituindo-se enquanto 
elemento estrutural que participa da própria organização das sociedades, manifestando-se de diversas formas (GOMES, et, al, 2007, p. 505).

Dessa forma, a violência acaba atingindo todas as classes sociais e, em todas as sociedades, é um ato de destruição, pois sempre um acaba sofrendo mais que o outro, uma vez que existe o que agride e o que sofre a violência. Porém, no caso da violência doméstica, as principais vítimas são as mulheres que sofrem a agressão de seus companheiros.

Destaca-se também o que a autora osterne (2011) fala sobre a violência em seu sentido amplo. Segundo ela, tanto os homens como as mulheres podem ser alvos de agressão, ocorrendo apenas uma diferenciação de onde essa violência vai ocorrer, pois o homem a sofre mais em espaços públicos, enquanto a mulher a sofre mais dentro da própria casa.

Com efeito, a violência se apresenta de forma diferenciada para homens e mulheres, pois, enquanto o homem sofre violência nas ruas, nos espaços públicos, praticada por outro homem, a mulher, na maioria absoluta dos casos, torna-se vítima da violência masculina primeiramente dentro de casa, depois no espaço privado, e seus agressores, geralmente, são (ou foram) seus namorados, maridos, filhos, companheiros, amantes ou indivíduos outros de alguma forma seus conhecidos (p. 131).

Diante disso, o termo violência tem uma grande abrangência. Existem vários tipos de violência, dentre eles a violência física, psicológica, sexual, moral e patrimonial, que podem estar presentes tanto em um ambiente intrafamiliar como em um ambiente extrafamiliar.

Na violência física, mesmo que não deixe marcas, o uso da força que ofenda o corpo da mulher ou sua saúde, já expressa esse tipo de agressão. Na psicológica, destaca-se um dano emocional e diminuição da autoestima, prejudicando seu desenvolvimento. A sexual está relacionada com o ato sexual não desejado, mediante intimidação, ameaça e força. A moral é qualquer calúnia, difamação. E a patrimonial refere-se a atos que destrua parcial ou total de objetos, instrumentos de trabalho (DIAS, 2008).

Além desses tipos de violência, destaca-se, assim, a violência vivenciada no contexto intrafamiliar, que é denominada de violência doméstica. Com isso, essa 
pesquisa se refere especificamente à violência doméstica contra a mulher. De acordo com Dias (2008) sobre o que se define violência doméstica,

Primeiro a Lei define o que seja violência doméstica (art. 5o): "qualquer ação ou omissão baseada no gênero que lhe cause morte, lesão, sofrimento físico, sexual ou psicológico e dano moral ou patrimonial". Depois estabelece seu campo de abrangência. A violência passa a ser doméstica quando praticada: a) no âmbito da unidade doméstica; b) no âmbito da família; ou c) em qualquer relação íntima de afeto, independente da orientação sexual (p. 40).

Assim, a violência doméstica independe da orientação sexual, podendo ser sofrida tanto pelo homem como pela mulher. Porém, existe uma maior abrangência para os casos em que a mulher é a vítima do ato violento. Dessa forma, para que seja violência doméstica, precisa acontecer dentro de um ambiente doméstico ou familiar, além de possuir ou ter possuído um vínculo afetivo.

O tema sobre violência doméstica, principalmente contra as mulheres, tem sido algo reincidente ao longo dos anos. Porém, mais do que apontar números e estatísticas, é importante compreender um pouco o contexto, os valores, as percepções, a subjetividade que perpassa esse ambiente de conflito, bem como buscar identificar o que essas mulheres vitimizadas podem ter em comum.

Segundo Trindade, Almeida e Rozendo (2008),

O Estado Brasileiro reconhece que necessita de empreender uma ação firme e coordenada com os estados e municípios criando, então, uma política de enfrentamento à violência contra a mulher, a qual se propõe a atuar junto à prevenção, ao atendimento multidisciplinar em rede e à ampliação de acesso das mulheres aos serviços de Justiça e Segurança Pública (Secretaria Especial de Políticas para as Mulheres, 2003, p. 41).

O reconhecimento das necessidades por parte do Estado é importante, mas sozinho ele não muda nada e não transforma o contexto violento em pacífico. Além de identificar as necessidades é preciso que o Estado estabeleça metas e prazos concretos para a realização dessa política de enfrentamento à violência contra a mulher, não apenas propondo uma mudança, mas viabilizando-a, tendo como referência o bemestar do sujeito e não uma mera ação de reconhecimento político. 
A Constituição Federal do Brasil, por sua vez, reconhece a violência doméstica por meio do parágrafo 8으, art. 226, o qual diz: “O Estado assegurará a assistência à família, na pessoa de cada um dos que a integram, criando mecanismos para coibir a violência no âmbito das relações" (Secretaria Especial de Políticas para as Mulheres, 2003).

É dever do Estado promover a assistência à família e coibir a violência, porém muitas das políticas públicas são desarticuladas, não funcionam como deveriam e terminam por não atingir os objetivos propostos. Além disso, muitos ainda desconhecem os direitos que lhes são assegurados e, por isso, não fazem uso destes como poderiam, não sendo orientadas a como, quando e em que circunstâncias utilizálos.

Segundo Dias (2008),

A Lei Maria da Penha não fere o princípio da igualdade estampado no caput do art. 5어 da Constituição Federal, pois visa à proteção das mulheres que sofrem com a violência dentro de seus lares, delitos que costumam cair na impunidade (p. 56).

A existência de uma lei que proteja a mulher e coíba atos de violência não assegura a esta a assistência necessária para que ela faça a escolha de denunciar. Mesmo existindo uma lei, muitas mulheres não dão queixa da violência que sofrem até mesmo dentro da própria casa.

As causas para tal atitude podem ser várias, mas pode-se destacar aquela em que o homem é o provedor da família, e a mulher, que não tem trabalho e vive apenas para cuidar da casa, é submissa a esse homem, acabando por ficar com medo de denunciá-lo.

Para Blay (2003), "Constatou-se que a maioria das vítimas (28\%) tinha profissão "não qualificada", seguidas pelas "do lar" (23\%). Cerca de $8 \%$ eram estudantes de vários níveis" (p. 95). Esses dados demonstram que uma boa quantidade de mulheres é dependente dos homens e essa dependência impede que elas realizem a denúncia do seu agressor.

Esse homem, como provedor, e essa mulher, como submissa às ordens desse homem, podem-se relacionar com a violência de gênero, pois existe uma desigualdade eles. 
Somos frutos da educação diferenciada, baseada na desigualdade e na metamorfose das relações...A desigualdade entre homens e mulheres desdobra-se e culmina nas diversas formas de violência contra mulher, tendo suas raízes construídas em alguns mitos consolidados ao longo dos tempos (SILVA, 2011, p. 2-3).

A violência, portanto, tem como uma de suas raízes a desigualdade entre os gêneros, visto que o ato violento acaba ocorrendo muitas vezes por ocorrência de uma disputa por fazer prevalecer o poder posto em risco, além de uma educação diferenciada para homens e mulheres, onde os homens devem ser fortes, com o poder de mandar, e as mulheres devem ser frágeis, emotivas e obedecer a ordens. Dessa forma, segundo Trindade, Almeida e Rozendo (2008), "assim sendo, o poder do homem é socialmente legitimado, seja no papel de esposo, seja no papel de pai" (p. 42).

Mesterman (1998) vai afirmar que a situação atual de violência pode estar atrelada a uma tentativa de reestabelecer o poder perdido ou até mesmo nunca alcançado. Diante do crescente papel da mulher na sociedade, papel este que faz a mulher adquirir direitos e poderes que até então eram cabíveis somente aos homens, pode gerar uma tensão e uma necessidade de autoafirmação por parte de ambos os lados, tornando o ambiente familiar mais propício a conflitos. (Secretaria de Políticas de Saúde, 2001).

Não é difícil perceber que a violência entre casais tem alcançado ao longo dos anos uma parcela cada vez mais significativa da sociedade. No entanto, é necessário compreender o ambiente, o contexto e o histórico de vida que terminam por influenciar as mulheres que vivenciam esse drama em suas próprias casas, fazendo-as permanecer em uma relação de violência.

Submetida, muitas vezes, a um histórico de violência, descrédito familiar e social, falta de autonomia e baixa autoestima, a mulher pode acabar se enxergando em um patamar abaixo do homem, o que acaba reconhecendo e validando a existência de uma desigualdade, uma vez que ela se submete às agressões e se vêem uma posição inferior, de impotência frente a esse homem, já que sente dependente dele.

Para diz Trindade, Almeida e Rozendo (2008), a violência doméstica se constrói a partir das relações desiguais entre homens e mulheres e se transmite de geração para geração. Essa dependência sentida tanto a nível financeiro quanto psicológico e 
emocional, faz com que estas se submetam e se conformem com a realidade, visto que não enxergam muitas perspectivas fora do relacionamento, o que faz com que muitas tragam o conhecido discurso popular: "ruim com ele, pior sem ele".

Com relação à desigualdade entre homens e mulheres, é possível destacar também o conceito sobre o machismo, que ainda é característico da sociedade de hoje, onde muitos homens ainda se colocam como que detentores de mais direitos e poder em relação à mulher.

A palavra "machismo", como se conhece na atualidade, está baseada em valores, percepções e atitudes adotadas em relação à diferença de gênero. Entende-se machismo como um conjunto de posturas, pensamentos e comportamentos de natureza social e patriarcal, que visam manter o sexo feminino em situação de dominação, subordinação, inferioridade e exploração(Cynthia,2005).

Sendo assim, o machismo contribui de maneira significativa para a violência doméstica, pois faz com que o homem se ache no direito de manter a mulher sob o seu poder e domínio, usando até mesmo da própria força para preservar sua autoridade e superioridade.

De acordo com Minayo (2005),

A concepção do masculino como sujeito da sexualidade e o feminino como seu objeto é um valor de longa duração da cultura ocidental. Na visão arraigada no patriarcalismo, o masculino é ritualizado como o lugar da ação, da decisão, da chefia da rede de relações familiares e da paternidade como sinônimo de provimento material: é o "impensado" e o "naturalizado" dos valores tradicionais de gênero (p. 23-24).

Ao olhar para a sociedade e sua história, não é difícil perceber que esse homem, dotado de poder e influência social, tem uma tendência a querer impor a sua forma de pensar e fazer prevalecer as suas opiniões e decisões, visto que foi reforçado ao longo da história a ser esse sujeito autônomo e detentor de mais direitos e poderes. No entanto, com o passar do tempo, a mulher, que antes não era considerada cidadã e por isso tinha que aprender a ser submissa, acatando as decisões dos homens, começou a ser vista de forma diferente, passando a ser mais creditada e valorizada pela sociedade.

A vida cotidiana das mulheres sofreu alteração, uma vez que essas mulheres começaram a ocupar o espaço das ruas, a trabalhar fora de casa, a estudar, conquistado 
assim espaço no mercado de trabalho (BLAY, 2003). Porém, percebe-se que, atualmente, existe ainda uma forte marca social que retrata o tempo em que a mulher deveria ser submissa a homem que, como o chefe da família, era tido como aquele que sabia mais e detinha maior poder sobre as decisões familiares.

Como diz Blay (2003),

Para enfrentar esta cultura machista e patriarcal, são necessárias políticas públicas transversais que atuem modificando a discriminação e a incompreensão de que os Direitos das Mulheres são Direitos Humanos. Modificar a cultura da subordinação de gênero requer uma ação conjugada (p. 96).

Dessa forma, o medo, por parte dessas mulheres de realizar a denúncia ainda permanece, pois, para elas, é difícil e complexo acreditar que esses homens são agressores e que elas são vítimas de violência doméstica.

Porém, as considerações sobre violência contra as mulheres sofreram modificações em função das transformações nas relações da família com a sociedade em termos econômicos, sócio-culturais, políticos e de papéis, na luta das mulheres pelo reconhecimento de seus direitos, nas questões sexuais e na relação de trabalho (RIBEIRO e COSTA, 2004). Percebe-se, assim, que são muitos os casos que envolvem a violência contra a mulher, mas, segundo Ribeiro e Costa(2004), o "grande número dos casos de violência intrafamiliar não são notificados, são guardados em segredo com a convivência de parentes, vizinhos e, muitas vezes, da própria vítima" (p. 49). Ou seja, muitos casos de violência doméstica contra a mulher ainda são camuflados, escondidos, guardados em segredo, e a mulher permanece nessa relação familiar de medo e angústia.

Assim, a permanência na relação de agressão para essas mulheres é influenciada por muitos fatores, uma vez que é muito difícil romper com esse parceiro. Segundo Soares (2005), as principais razões são: o risco de romper a relação, a procura por ajuda é vergonhoso e gera medo, a esperança de que o marido mude seu comportamento, o isolamento da vítima das redes sociais, a sociedade despreparada para lidar com esse tipo de violência, muitos obstáculos que impedem o rompimento, a dependência econômica de seus parceiros violentos e o processo que possui um tempo para cada mulher conseguir romper essa relação.

É importante ressaltar também os dados da pesquisa realizada pelo Instituto de 
pesquisa Econômica Aplicada - IPEA sobre como a violência contra a mulher é tolerada no país. Os dados mostram que $65 \%$ dos brasileiros acham que mulheres que usam roupas mostrando seu corpo merecem ser atacadas (Sistema de Indicadores de Percepção Social, 2014). Isso demonstra que a mulher ainda é julgada pelo seu modo de vestir, de andar, como se não pudesse mais realizar uma escolha pelo seu estilo, mas seguir o que a sociedade considera correto.

Esses dados lançados pelo IPEA foram novamente analisados e foi percebido um erro. Houve uma troca nos gráficos e a porcentagem correta seria $26 \%$ dos brasileiros acham que mulher que usa roupa mostrando o corpo deve ser atacada. Mesmo sendo um valor abaixo de 50\%, ainda se percebe como a mulher é julgada.

Diante disso, é necessário parar um pouco de olhar para o todo e começar a olhar mais para o particular, parar de olhar para a massa e começar a olhar para o indivíduo, parar de tentar compreender a violência de forma geral para se aprofundar naquilo que é específico, aquilo que é vivenciado e influencia as ações e reações daqueles que são vítimas da violência. Compreender o que é particular, individual e específico do sujeito é adentrar no mundo de sentimentos, medos e angústias que precisam ser mais acessadas e discutidas por parte destes, para que estes aprendam a se posicionar de forma diferente em relação a si, ao outro e ao mundo.

\section{CONSIDERAÇÕES FINAIS}

A questão da violência, principalmente a doméstica contra a mulher, não é uma característica da sociedade atual, mas uma consequência de uma cultura e de uma sociedade edificada a partir de uma série de percepções, concepções e significações que desfavoreceram a mulher ao longo da história.

A partir de tudo isso, percebe-se que a violência contra a mulher é uma questão bastante abrangente que envolve diversos fatores políticos, econômicos e sociais que influenciaram a história ao longo dos anos. Diante de tudo o que foi apresentado até aqui, pode-se perceber que os diferentes fatores e motivos que podem influenciá-las a permanecer em uma postura de silêncio, passividade e subordinação, escolhendo não denunciar o seu agressor, giram em torno de duas realidades, pelas quais a vida do homem e da sociedade foi construída ao longo da história: A Realidade Social e a Realidade Psicológica. 
A Realidade Social consiste no contexto social, político e econômico, nos quais a relação entre o homem e a mulher foi sendo construída e a sociedade foi se organizando e se estruturando. Ao olhar para a história percebe-se que essa relação foi muito marcada por desigualdades, preconceitos, discriminações e abuso de poder.

A mulher passou por uma história muito forte de subordinação, de dependência e de desvalorização. Nos tempos em que a mulher nem mesmo era considerada cidadã, não tinha voz, nem vez e muito menos direito a voto, foi-se construindo uma cultura na qual a mulher era inferior ao homem, estando destinada apenas a cuidar da casa.

Essa cultura foi criando uma concepção de que a mulher não era apta para trabalhar e nem para ter influência sobre a vida política e social. Deste modo, a experiência de ser subjugada, desconsiderada, desvalorizada, submetida a leis onde prevaleciam os homens e a eles eram dados plenos poderes sobre elas, gerou uma forte marca que influenciou a forma como a mulher passou a se enxergar e na forma como ela possou a ser enxergada pelo homem.

Embora a mulher, com o passar dos anos, tenha mostrado a sua importância, sua capacidade e tenha conquistado espaço e reconhecimento nos âmbitos sociais, políticos e econômicos, percebe-se que, nos dias de hoje, muitas ainda trazem marcas do tempo em que estavam sujeitas ao domínio dos homens.

Diante da cultura forte do machismo, que perdura até os tempos atuais, muitas mulheres acabaram fazendo uma introjeção de mentalidades, concepções e sentimentos acerca de si mesmas que Ihes desfavorecem e ainda legitimam esse lugar do homem de detentor de poder. Envolvidas por essa cultura, muitas mulheres assumiram o papel de zelarem pelo bem-estar dos homens, alimentá-los, prover as suas necessidades, encobrir os seus erros e defeitos e satisfazê-los. Isso acontece porque, além da Realidade Social que explica essa história de sujeição da mulher, que termina por promover a violência, principalmente a doméstica, existe uma Realidade Psicológica que acompanhou e acompanha todo esse contexto social sob o qual esta mulher esteve submetida.

O medo, a vergonha, o isolamento, a negação do sofrimento e a angústia comum entre essas mulheres são também consequência de uma história de sofrimento psíquico, de sentimentos de incapacidade, de insegurança e necessidade de encobrir os problemas que as paralisam frente aos seus próprios processos de autonomia. 
Com isso, diante das leituras e dados apreendidos, percebe-se que os possíveis motivos que influenciam as mulheres vítimas de violência doméstica a permanecerem com o agressor e não o denunciarem estão abarrotados de sentimentos, pensamentos e concepções que são também resultados de consequências psicológicas que refletem na forma como elas percebem a si mesmas e o mundo a sua volta.

Realizar a denúncia representa todo um processo que essas mulheres devem vivenciar, pois a dor não é somente física, mas é também emocional, pois esses homens significam algo para elas, mesmo que seja pelo sofrimento, já que muitas sofrem essa violência por parte dos seus esposos. E reconhecer que ele é um agressor causa muito sofrimento, uma vez que o escolheu para constituir uma família. Assim, muitas ainda permanecem em silêncio, demonstrando que esse assunto ainda precisa ser bastante discutido e questionando pela sociedade, onde a mulher deve ser valorizada, respeitada e cuidada, pois é de direito que lhe foi conferido.

\section{REFERÊNCIAS}

ALBUQUERQUE, Flávia. Pesquisa revela que $\mathbf{7 0 \%}$ das pessoas acreditam que mulher sofre mais violência dentro de casa. Agência Brasil. Brasília, 2013.

BASTOS, Núbia Maria Garcia. Introdução à metodologia do trabalho acadêmico. 4. ed. Fortaleza: Nacional, 2007.

BLAY, Eva Alterman. Violência contra a mulher e políticas públicas.Estudos Avançados, São Paulo, v. 17, n. 49, 2003. Disponível em: <http://www.scielo.br/pdf/ea/v17n49/18398.pdf> Acesso em: 20/02/2014.

CASIQUE, Letícia Casique e FUREGATO, Antônia Regina Ferreira. Violência contra mulheres: reflexões teóricas. Revista Latino-Americana de Enfermagem, São Paulo, v. 14, n. 6, 2006. Disponível em: <http://www.scielo.br/pdf/rlae/v14n6/pt v14n6a18.pdf > Acesso em: $18 / 02 / 2014$.

BRASÍLIA. Comissão Parlamentar Mista de Inquérito. Relatório Final. Brasília, 2013.

DIAS, Maria Berenice. A Lei Maria da Penha na Justiça: a efetividade da Lei 11.340/2006 de combate à violência doméstica e familiar contra a mulher. São Paulo: editora revista dos tribunais, 2008.

DUK, Cynthia. Educar na diversidade: material de formação docente. Brasília: Ministério da Educação, Secretaria de Educação Especial, 2005. 
GIL, Antônio Carlos. Métodos e técnicas de pesquisa social. 6ạ edição. São Paulo: Atlas, 2008.

GOMES, Nadilene Pereira, et al. Compreendendo a violência doméstica a partir das categorias gênero e geração. Acta Paulista de Enfermagem, v. 20, n. 4, p. 504508, São Paulo, 2007.

MINAYO, Maria Cecília de Souza. Laços perigosos entre machismo e violência. Revista Ciência \& Saúde Coletiva, Rio de Janeiro, v. 10, n. 1, 2005. Disponível em: $<$ http://www.scielosp.org/scielo.php?script=sci arttext\&pid=S1413$81232005000100005 \&$ lang=pt $>$ Acesso em: 18/02/2014.

ODÁLIO, Nilo. O que é violência. Coleção primeiros passos. São Paulo: Brasiliense, 2004.

OSTERNE, Maria do Socorro Ferreira. A violência contra a mulher na dimensão cultural da prevalência do masculino. 0 público e o privado, n. 18, julho/dezembro, Fortaleza, 2011.

RIBEIRO, Maria Alexina e COSTA, Liana Fortunato (orgs). Família e problemas na contemporaneidade: reflexões e intervenções do grupo socius. Brasília: Universa, 2004, p. 45-69.

SABINO, Mario. Sangue e Olho Roxo.São Paulo. Veja. v. 47, n. 11, p. 84-85, 12 março, 2014.

BRASÍLIA. Secretaria Especial de Políticas para as Mulheres. Programa de prevenção, assistência e combate à violência contra a mulher - Plano Nacional. Diálogos sobre violência doméstica e de gênero:construindo políticas públicas. Brasília: A Secretaria, 2003.

BRASÍLIA. Secretaria de Políticas de Saúde. Violência intrafamiliar: orientações para prática em serviço. Brasília: Ministério da Saúde, 2001.

SILVA, Carla da. A desigualdade importa pelos papeis de homem e mulher: uma possibilidade de construção da igualdade de gênero. 2011. 9 f. Parte deDissertação (Mestrado em Serviço Social). Pontifícia Universidade Católica deSão Paulo, São Paulo, 2011.

BRASÍLIA. Sistema de Indicadores de Percepção Social. Tolerância social à violência contra as mulheres. Brasília: Ipea, 2014.

SOARES, Bárbara M. Enfrentando a violência contra a mulher. Orientações práticas para profissionais e voluntário (as). Brasília: Secretaria Especial de Políticas para as Mulheres, 2005. 
TRINDADE, Ruth França Cizino da; ALMEIDA, Ana Maria de; ROZENDO, Célia Alves. Infidelidade masculina e violência doméstica: vivência de um grupo de mulheres. Ciencia y Enfermeira, Chile, v. 14, n. 2, 2008. Disponível: <http://www.scielo.cl/pdf/cienf/v14n2/art06.pdf> Acesso em: 20/02/2014.

TROCOLI, Grace; SANTOS, Maria Inês Detsi Andrade. A pesquisa científica. Fortaleza: Unifor, p. $01 \quad-\quad 18,2005 . \quad$ Disponível em: <https://uol.unifor.br/oul/conteudo/F9885231649/H706 unid04 a pesquisa C ientifica.pdf > Acesso em: 20/03/2014.

WAISELFISZ, Julio Jacobo. Mapa da Violência 2012. Os novos padrões da violência homicida no Brasil. São Paulo, Instituto Sangari, 2011. 


\title{
CAPÍTULO V
}

\section{A ESCOLA COMO ESPAÇO OPRESSOR: EXCLUSÕES E VIOLÊNCIAS VIVENCIADAS POR ESTUDANTES LGBT NO AMBIENTE ESCOLAR}

Caio Benevides Pedra ${ }^{1}$

\begin{abstract}
${ }^{1}$ Mestre em Direito pela Universidade Federal de Minas Gerais e em Administração Pública pela Fundação João Pinheiro com pesquisas relacionadas ao acesso à cidadania pela população LGBT+ no Brasil. Autor dos livros "Cidadania Trans: o acesso à cidadania por travestis e transexuais no Brasil" e "Direitos LGBT+: a LGBTfobia estrutural e a diversidade sexual e de gênero no direito brasileiro", lançados em 2020. Membro do projeto de extensão Diverso UFMG e da Comissão de Diversidade Sexual da OAB/MG.
\end{abstract}

\section{RESUMO}

A escola tem um papel fundamental no acesso à cidadania pelos sujeitos por contribuir e atuar diretamente na formação desses cidadãos. O espaço escolar, no entanto, não está ainda preparado para acolher e valorizar as diversidades e, por repetir e impor padrões sociais excludentes e discriminatórios, costuma sediar violências de toda natureza contra aqueles que não se enquadram de alguma maneira. Este trabalho pretende reunir alguns dados e discussões sobre as exclusões vivenciadas pela população LGBT no ambiente escolar, por meio de pesquisa bibliográfica e do levantamento de dados produzidos por pesquisas realizadas principalmente pela sociedade civil.

Palavras-chave: LGBT; exclusão; cidadania; educação; violência.

\section{INTRODUÇÃO}

A principal importância da educação em um estado democrático de direito é nos ensinar a ser cidadãos. Como toda propriedade humana, a cidadania é resultado de uma prática, de um processo que se inicia exatamente com a educação, seja ela formal (escola) ou informal (convivência em diversos ambientes). O processo de aprender a ser cidadão constitui-se muito mais de aproximação e reflexão que da simples repetição de leis (CORTINA, 2005).

Supor, no entanto, que a existência de um sistema de ensino é suficiente para que o acesso à educação seja franqueado a todos os grupos é um equívoco muito comum. Do ponto de vista formal, todo e qualquer jovem brasileiro pode, hoje, frequentar uma escola, da alfabetização até a conclusão do ensino médio. No entanto, quando nos atentamos às realidades vivenciadas por determinados grupos, é possível 
perceber que não basta que a escola esteja disponível, ela precisa estar pronta para receber todos os jovens. E, para isso, é importante que ela se configure como um espaço seguro, o que veremos que, infelizmente, ainda está longe de ser realidade para alguns grupos sociais.

Gomà (2004) discute a ideia da exclusão como um fenômeno multifacetado verificável na análise dos quadros e grupos a partir de eixos específicos. Nesse sentido, o autor propõe o âmbito de exclusão formativa, que se refere, de forma geral, à exclusão no acesso à educação e se intensifica quando conjugadas determinadas circunstâncias, como "não escolarização", "fracasso escolar", "analfabetismo ou capital formativo muito baixo" e "analfabetismo digital". Esses pontos constituem um rol meramente exemplificativo, mas os dados e estudos aqui reunidos extrapolam esses eixos e fornecem um quadro mais amplo da exclusão da população LGBT $^{1}$ nas escolas.

O que vamos analisar ${ }^{2}$, então, é em que medida a escola está preparada para lidar com a diversidade e possibilitar, às pessoas LGBT, essa formação que alguns autores definem como fundamental para o exercício da cidadania. Para tanto, recorremos a estudiosos da educação que se propuseram a analisar o tratamento das diversidades (sexual e de gênero) e reunimos pesquisas recentes sobre a trajetória da população LGBT nos ciclos da educação básica, que produziram dados importantes e, apesar da subnotificação, nos permitem compreender brevemente o papel da escola no fortalecimento das exclusões vivenciadas por estudantes LGBT.

\section{A ESCOLA COMO UM ESPAÇO DE OPRESSÕES}

Marshall (1967, p. 73) afirma que a "educação das crianças está diretamente relacionada com a cidadania". A educação, para o autor, "é um pré-requisito necessário da liberdade civil". Assim, quando o Estado garante que todas as crianças sejam educadas, o que ele está tentando estimular na verdade é o desenvolvimento do

\footnotetext{
${ }^{1} \mathrm{O}$ reconhecimento de identidades não hegemônicas já se encontra extremamente avançado e essa sigla já é bem maior, além de nunca parar de crescer. Nesse trabalho, no entanto, optamos pela utilização da sigla "LGBT" por ser a formação atualmente reconhecida pelo Estado brasileiro em seus documentos oficiais.

${ }^{2}$ Uma versão preliminar deste texto consta da dissertação que apresentei à Escola de Governo Professor Paulo Neves de Carvalho, da Fundação João Pinheiro, como conclusão do Mestrado em Administração Pública, em 2018, intitulada "Acesso a cidadania por travestis e transexuais no Brasil: um panorama da atuação do Estado no enfrentamento das exclusões".
} 
cidadão em formação. O objetivo da educação, reconhecida pelo autor como um direito social, é, nesse contexto, "moldar o adulto em perspectiva" para que ele possa se posicionar diante das exigências e da natureza da cidadania. Os direitos civis seriam destinados a serem utilizados por pessoas inteligentes, que saibam ler e tenham bom senso. Então, não se trata, aqui, do direito de as crianças frequentarem a escola, mas do direito do cidadão adulto ter sido educado.

Segundo Carvalho (2017), contudo, a educação popular é uma exceção na sequência de direitos descrita por Marshall (1967). Definida como direito social, a educação tem sido, historicamente, um pré-requisito para a expansão de todos os outros direitos. Marshall (1967) chega a se referir à educação como pré-requisito para o exercício dos direitos civis, mas é Carvalho (2017) quem acrescenta a noção de que a ausência de uma população educada tem sido sempre um obstáculo à construção da cidadania civil e política. Para isso, ele afirma que a educação popular foi introduzida na história dos países em que a cidadania se desenvolveu com maior rapidez, permitindo que as pessoas tomassem conhecimento de seus direitos e se organizassem para lutar por eles.

A educação, então, como processo de aprendizagem e aperfeiçoamento, prepara as pessoas para a vida e para a convivência social, tornando-as mais úteis para a coletividade e permitindo que participem mais efetivamente no estudo e na decisão dos assuntos de interesse comum. Por isso, deve ser prioridade de todos os governos. É importante que todos tenham igual oportunidade de acessar a educação. Ou seja, não é suficiente assegurar que todos tenham apenas o mesmo direito a ir à escola, o que é fundamental é que todos tenham efetivamente a mesma possibilidade de exercer esse direito (DALLARI, 2004).

Nesse contexto, é importante ressaltar a ausência de dados detalhados por parte do IBGE, o que representa um grande dificultador nesses estudos, uma vez que a política educacional utiliza indicadores universais, que não expressam dimensões específicas como gênero, orientação sexual e territorialidade, por exemplo. Dessa forma, a maior parte das pesquisas trazidas (organizadas principalmente pela sociedade civil) ainda se volta para a população LGBT como um todo, tendo poucas especificidades sobre os grupos que compõem essa sigla e que, claro, vivenciam formas diferentes de exclusão. Além disso, essa falta de dados oficiais é, por si, um indicativo dessas exclusões. 
A centralidade da escola nessa discussão deve-se à importância que esse espaço tem no âmbito das instituições sociais com as quais os indivíduos têm contato por dar continuidade ao processo de socialização que se inicia com a família no nascimento do sujeito (MIRANDA, 2016). Ainda que diversos espaços sociais e institucionais concorram para a manutenção da lógica "heteronormativa da sequência sexo-gênero-sexualidade", a escola e a família parecem sediar momentos cruciais de imposição das discriminações (JUNQUEIRA, 2016, p. 107).

É importante anunciar que a escola não se distingue das outras instituições da vida social e que não possui a responsabilidade única de transformação social, mas reconhecemos a capacidade educacional de propor e promover processos de relações sociais mais igualitárias e equânimes. O que distingue a escola das demais instituições de gestão pública e privada é a possibilidade de problematizações, inquietudes e alterações de formas de pensar, a partir do arcabouço de informações e conhecimento. A escola possibilita a ampliação de debates que versam sobre a multiplicidade do exercício da sexualidade e da vivência de gênero não hegemônicas, sobre a autonomia dos corpos, das configurações familiares; processos de discussões não habituais no ambiente familiar, religioso e de determinados grupos sociais. (LACERDA, 2018, p. 221).

A escola, nesse contexto, ajuda a construir a cidadania, que opera como instrumento de estratificação social, ou seja, o status que a educação permite adquirir acompanha o indivíduo por toda a sua vida, com um "rótulo de legitimidade" por ter sido conferido por uma instituição cuja finalidade é dar aos cidadãos instrumentos para o exercício dos seus justos direitos. (MARSHALL, 1967, p. 102). A atividade de educar, então, precisa romper as "barreiras do localismo provinciano" e entender que nada do que é pessoal pode ser afastado das pessoas sem que isso lhes cause grande perda. (CORTINA, 2005, p. 193).

A educação e a escola são fundamentais para o desenvolvimento de uma sociedade. Mas a educação não se restringe aos espaços escolarizáveis. Além da família e dos grupos espontâneos, é preciso reconhecer a importância dos espaços não formais de educação de sujeitos que também se destinam a transformar pessoas em cidadãos, tais como os movimentos sociais e as organizações não-governamentais. Esses espaços 
oferecem diferentes contextos e aprendizados que podem ser aproveitados pela educação formal para uma educação mais inclusiva, já que os educadores que integram os ambientes formais de educação ainda têm formações muito restritas, que poderiam ser ampliadas pelo intercâmbio de informações. Aprender a articular essas compreensões pode ajudar a fazer da educação mais que um espaço de formação para o trabalho, um espaço para o desenvolvimento de uma cidadania que inclua as diversidades. (TORRES, 2013).

Os movimentos sociais e ONGs articulam-se para levar para a educação formal conteúdos trabalhados majoritariamente pela informal já há algum tempo. A década de 1990 foi marcada por um contexto reivindicatório por parte dessas instituições, que denunciavam as práticas discriminatórias presentes na educação com a finalidade de pedir mudanças. O Ministério da Educação (MEC), então, promoveu iniciativas e debates sobre as formas e possibilidades de superar a discriminação das "diferenças" nas instituições escolares. (ZAGO; GUIZZO, 2016).

Essas interações entre o MEC e a sociedade ainda existem e são fundamentais para que os currículos escolares abordem questões sociais, já que é também função da escola preparar o sujeito para ser um cidadão, como vimos. Nesse contexto, o currículo torna-se um espaço de constante discussão e construção, refletindo as relações de poder dominantes e se organizando a partir da agenda governamental:

O cotidiano escolar interage e interfere em cada aspecto do conjunto de saberes e práticas que constituem o currículo formal e o currículo oculto. O currículo (seja ele qual for) constitui-se um artefato político e uma produção cultural e discursiva. Isto é, o currículo se relaciona à produção sócio-histórica de poder por meio de produção de regras e padrões de verdade, bem como da seleção, organização, hierarquização e avaliação do que é definido como conhecimento ou conteúdo escolar. É um campo de permanentes disputas e negociações em torno de disposições, princípios de visão e de divisão do mundo e das coisas - especialmente das que concernem ao mundo da educação escolar às figuras que o povoam e, ali, (re)definem sentidos e (re)constroem significados. É um espaço de produção, contestação e disputas que abriga relações de poder, formas de controle, possibilidades de conformismo e resistência. (JUNQUEIRA, 2016, p. 102-103). 
Isso fica muito evidente no quadro atual do Brasil, marcado por retrocessos em diversas áreas. Nesse momento, grande parte do Legislativo (e o Executivo federal) organiza-se para impedir a discussão da temática do gênero nas escolas. E os resultados já começaram a aparecer: em 2017, acatando sugestões do $\mathrm{MEC}^{1}$, o Conselho Nacional de Educação retirou todas as referências relacionadas a gênero e orientação sexual do texto da Base Nacional Comum Curricular². Além disso, os "preconceitos de toda natureza" (já que o texto original, que mencionava os preconceitos em razão de gênero e orientação sexual, foi alterado) serão discutidos em ensino religioso, de acordo com as tradições religiosas ${ }^{3}$.

A movimentação conservadora e o avanço dos seus interesses sobre o currículo escolar e, consequentemente, o cerceamento do debate sobre a diversidade nas escolas de todo o país são preocupantes e só demonstram a urgência e relevância do tratamento desses temas. Segundo Silva (2016, p. 202), é importante que o currículo abrace "as questões de gênero, as identidades sexuais e o combate à homofobia" termo que, até hoje, é ainda muito utilizado abrangendo todas as identidades e, portanto, com o sentido de LGBTfobia. Segundo o autor, as poucas vezes em que essas discussões podem ser trabalhadas, de acordo com os Parâmetros Curriculares Nacionais (PCNs), é nas discussões sobre os riscos de contaminação pelo vírus HIV (já que esse tema e a gravidez na adolescência são temas transversais incutidos nos PCNs), o que "não engloba a complexidade da diversidade sexual" e ainda reproduz um "viés biologizante e aterrorizante".

A associação entre a população LGBT e as infecções sexualmente transmissíveis (ISTs) é antiga. A epidemia do HIV foi, talvez, a primeira grande vilã da história do movimento homossexual brasileiro ${ }^{4}$, já na década de 1980, em decorrência da popular associação entre HIV e homossexualidade. O vírus dizimou grande parte da população e chegou a ser conhecido como "peste gay", o que aumentou consideravelmente a

\footnotetext{
${ }^{1}$ Disponível em: https://oglobo.globo.com/sociedade/educacao/cne-retira-genero-orientacaosexual-da-base-curricular-22179063\#ixzz5BNtSBNhX. Acesso em: 20 jun. 2020.

${ }^{2}$ Disponível em: http://basenacionalcomum.mec.gov.br/a-base. Acesso em: 20 jun. 2020.

3 Disponível em: http://www1.folha.uol.com.br/educacao/2017/12/1940989-governo-temeresvazia-genero-na-base-curricular-e-mistura-tema-com-religiao.shtml. Acesso em: 20 jun. 2020.

${ }^{4}$ Inicialmente, o Movimento LGBT surgiu como Movimento Homossexual, já que os primeiros grupos se organizaram sob a coordenação de homens e só posteriormente as outras identidades se organizaram. Para maior detalhamento, Facchini (2005).
} 
violência contra pessoas trans e homossexuais, socialmente responsabilizados pela sua proliferação (FACCHINI, 2005).

Essa associação discriminatória e injustificada ainda povoa o imaginário popular e perdura até os dias de hoje, inclusive nas políticas públicas. A aproximação entre o Poder Público e o movimento LGBT teve início a partir da saúde. As políticas de atenção à saúde e combate ao HIV foram a porta de entrada para o contato entre ativistas e a União, por meio de instâncias deliberativas instituídas pelo Ministério da Saúde (PEDRA, 2018).

Os Parâmetros Curriculares Nacionais (PCNs) têm como objetivo apresentar os pontos comuns a que os sistemas de ensino devem obedecer de acordo com os princípios e metas do projeto educativo assumido pelo Brasil. Assim, essas diretrizes têm abrangência nacional, mas são abertas e flexíveis às realidades regionais e locais (VIDAL, 2017).

\footnotetext{
É imprescindível a liberdade e a autonomia da escola, mas também é imprescindível o trabalho de sensibilização e mobilização do professor - enquanto possibilitador de transformações e mudanças - para com o trato do tema. Não porque existem os PCNs, mas porque a sexualidade é parte integrante do ser humano, e a escola, como responsável pelo processo formal de ensino, deve compartilhar e assumir a sua responsabilidade pela educação integral do aluno. (VIDAL, 2017, p. 57).
}

A escola enquanto espaço para a formação cidadã deve priorizar a formação de sujeitos capazes de exercer seu papel social. Para tanto, precisa descontruir mitos e preconceitos que fundamentem oposições aos valores democráticos e ao respeito às diversidades cultural e de gênero (NEVES; CALEGARE; SILVA, 2016).

Uma vez assegurada a educação como direito de todos, a escola é o espaço público capaz de garantir que essa educação "não seja racista, sexista ou LGBTfóbica, nem reproduza qualquer tipo de segregação discriminatória". (JUNQUEIRA, 2015, p. 41). Mesmo porque o ensino é norteado por princípios, dentre os quais se destacam o tratamento igual a todos os alunos, o respeito à diversidade, a oferta de ensino público de qualidade e a valorização dos profissionais que fazem a educação (MIRANDA, 2016). Construir um ambiente escolar de convivência e diálogo, que contemple e acolha bem toda uma diversidade de sujeitos e, principalmente, que não exclua ou discrimine 
concepções ou representações do que de alguma forma subverte a expectativa social é, então, o grande desafio das novas gerações de educadores (BORTOLINI, 2011).

Para tanto, os autores que se dedicam a esses temas apontam a necessidade de que os educadores estejam sempre atentos às discriminações, mesmo as que pareçam inofensivas (mas que também podem causar traumas e sofrimento), e estimulem o sentimento de igualdade desde cedo, da forma mais adequada a cada faixa etária. 0 educador que se cala diante de práticas discriminatórias e violentas não apenas é conivente com elas, mas perde a oportunidade de estimular em seus/suas alunos "o respeito pela dignidade da pessoa humana, a tolerância pelas diferenças e o sentimento de aceitação" (MIRANDA, 2016, p. 149).

A importância da postura dos educadores está na centralidade que os temas relacionados à sexualidade exercem na nossa sociedade. A sexualidade faz parte dos sujeitos e, assim, não pode ser negligenciada. Dessa forma, mesmo quando uma escola opta por não discutir a sexualidade e as questões de gênero (geralmente sob o argumento de que essa competência seria da família), estas questões não deixam de ser discutidas porque estão diariamente presentes na vida dos estudantes. Elas só passam a ser discutidas sem o acompanhamento por parte do educador ${ }^{1}$. (ROTONDANO, 2016).

As escolas prestariam um relevante serviço aos direitos humanos, à cidadania e ao incremento da qualidade da educação se dedicassem à desestabilização de práticas, atitudes, valores e normas que investem nas polarizações dicotômicas, no binarismo de gênero, nas segregações, na naturalização da heterossexualidade, na essencialização das diferenças, na fixação e reificação de identidades, na (re)produção de hierarquias opressivas. Isso, porém, sem desconsiderar que, graças às cambiantes operações da heterossexualidade hegemônica e obrigatória, impugnações do binarismo de gêneros podem ser acompanhadas de novos métodos de normatização heterorreguladora. (JUNQUEIRA, 2016, p. 111).

Infelizmente, o que se verifica é a forte presença "de valores impregnados de concepções retrógradas e repletas de pré-concepções e discriminações" no currículo e

${ }^{1} \mathrm{O}$ ideal, segundo Vidal (2017, p. 76), seria que, para além das discussões e atividades propostas e conduzidas pelos professores, as escolas pudessem contar com a orientação de um psicopedagogo, profissional cuja formação permite compreender o desenvolvimento humano e, consequentemente, o desenvolvimento da sexualidade (parte do desenvolvimento da pessoa), detendo conhecimentos teóricos que podem facilitar o aprendizado desses temas. 
no cotidiano escolar. Ao se calar frente à proteção da diversidade, segundo Junqueira (2015, p. 38-39), a escola "permite e, de várias formas, transmite o heterossexismo e a LGBTfobia, principalmente pela reprodução de padrões e conceitos próprios da heteronormatividade".

O que se vê, portanto, é um modelo de escola que se configura historicamente como instituição disciplinadora de corpos (NEVES; CALEGARE; SILVA, 2016) e se utiliza de símbolos e códigos para delimitar espaços e definir o que cada jovem pode e não pode fazer:

Diferenças, distinções, desigualdades... A escola entende disso. $\mathrm{Na}$ verdade, a escola produz isso. Desde seus inícios, a instituição escolar exerceu uma ação distintiva. Ela se incumbiu de separar os sujeitos tornando aqueles que nela entravam distintos dos outros, os que a ela não tinham acesso. Ela dividiu também, internamente, os que lá estavam, através de múltiplos mecanismos de classificação, ordenamento, hierarquização. A escola que nos foi legada pela sociedade ocidental moderna começou por separar adultos de crianças, católicos de protestantes. Ela também se fez diferente para os ricos e para os pobres e ela imediatamente separou os meninos das meninas. (LOURO, 1997, p. 57).

Esse espaço escolar recebe estudantes LGBT, mas não os aceita completamente. Exige deles um "comportamento adequado" que mais funciona como uma tentativa de os aproximar dos padrões socialmente impostos. Sem poder expressar ou aparentar, em nenhum momento, a sua sexualidade e/ou a sua identidade, o que esses jovens fazem é reprimir suas liberdades e as formas como se expressariam. Enquanto isso, as escolas acolhem as ditas "minorias", mas as controlam para que permaneçam dessa forma, como minorias que não ameacem a cisheteronormatividade e os paradigmas fundamentais do binarismo de gênero (BORTOLINI, 2011).

A tolerância propagada e defendida existe desde que esses indivíduos não se organizem e não reivindiquem seus espaços. (ABRAMOVAY; CASTRO; WAISELFISZ, 2015). Diante do bullying, da incompreensão e da própria ignorância em vários aspectos, a escola se cala em prol da defesa da "norma" ou da "normalidade". E, ao se omitir em casos de violência, que são muito comuns, a escola torna-se um espaço de insegurança para os jovens, como veremos. 
A negação dos/as homossexuais no espaço legitimado da sala de aula acaba por confiná-los às "gozações" e aos "insultos" dos recreios e dos jogos, fazendo com que, deste modo, jovens gays e lésbicas só possam se reconhecer como desviantes, indesejados ou ridículos. (LOURO, 1997, p. 68).

\section{AS EXPERIÊNCIAS DE ESTUDANTES LGBT NA ESCOLA}

O sistema escolar reflete a ideologia sexual dominante na sociedade e reproduz identidades rígidas e fixas no tempo, que integram um ordenamento hierárquico que estigmatiza e patologiza quem a ele não se submete. A própria linguagem utilizada pelo ambiente escolar institui os lugares que homens e mulheres devem ocupar e silencia, oculta e anula os sujeitos que questionam os padrões de gênero. (ROTONDANO, 2016). E essas diferenciações são impostas de forma autoritária e incutidas ao longo do desenvolvimento das crianças e jovens, fortalecendo a sensação de não pertencimento. Além do sofrimento mental acarretado por essas imposições, a violência direcionada a quem desrespeita de alguma forma esses estereótipos manifesta-se de diversas maneiras.

Uma pesquisa da Fundação Perseu Abramo ${ }^{1}$ revelou que $87 \%$ da comunidade escolar (alunos, professores e pais) reconhecem ter algum grau de "homofobia", 35\% dos pais de alunos não gostariam que seus filhos estudassem com um colega "homossexual"2, e 60\% dos professores admitem não ter base para lidar com a diversidade sexual. Para Silva (2016), o que dados como esses demonstram é que, além de a escola se constituir muitas vezes como um ambiente fomentador de desigualdades e violências, a discriminação se mantém e se sustenta também graças ao despreparo dos educadores para lidar com as temáticas da diversidade, o que os leva a não perceber determinadas situações ou até mesmo reproduzir discriminações.

${ }^{1}$ A pesquisa "Diversidade Sexual e Homofobia no Brasil: Intolerância e respeito às diferenças sexuais?" foi realizada em 2008 e divulgada em 2009 pela Faculdade de Economia, Administração e Contabilidade da Universidade de São Paulo e está disponível em: https://fpabramo.org.br/publicacoes/wp-content/uploads/sites/5/2017/05/pesquisa-lgbt.pdf. Acesso em: 20 jun. 2020.

${ }^{2}$ Nesta seção, retomaremos estudos desenvolvidos ao longo dos últimos anos e, em alguns deles, em razão da data de realização ou de divulgação e da lenta maturação social das terminologias adequadas, os termos "homossexual" e "homofobia" são utilizados para se referirem a toda a população LGBT e à LGBTfobia. Os dados foram mantidos da exata forma em que foram produzidos e divulgados, mas essa ressalva precisa ser feita. Os dados aqui utilizados referem-se a toda a população LGBT, o que eles não representam são as subdivisões internas a esse grupo. 
Impedida de contribuir para a promoção de relações democráticas em virtude de uma construção histórica que contribui para a invisibilização das diferenças e não se preocupa em reconhecer as diversidades, a escola classifica os corpos em apenas duas identidades de gênero, com base em fatores unicamente biológicos, ignorando os aspectos políticos e culturais que os compõem (NEVES; CALEGARE; SILVA, 2016).

A escola tornou-se um espaço em que rotineiramente circulam preconceitos que colocam em movimento discriminações de diversas ordens: classismo, racismo, sexismo, heterossexismo, homofobia, capacitismo e outras formas de gestão das fronteiras da normalidade que fazem parte da cotidianidade escolar. Não são elementos intrusos e sorrateiros, que, além de terem entrada franca, agem como elementos estruturantes do espaço escolar, onde são cotidiana e sistematicamente consentidos, cultivados e ensinados, produzindo efeitos sobre todos/as. (JUNQUEIRA, 2016, p. 103).

Os processos de construção dos sujeitos orientados pela heteronormatividade ensinam desde cedo a rejeitar as performances sociais que desafiam a lógica binária dos gêneros, sempre associada ao sexo biológico, por meio de violações que se manifestam em atitudes, discursos e comportamentos LGBTfóbicos. Esses processos aumentam e alimentam discriminações que se desenvolvem principalmente entre meninos e rapazes. (JUNQUEIRA, 2016).

Nesse sentido, a Pesquisa "Juventudes na Escola, Sentidos e Buscas: Por que frequentam ?"1 ouviu 8.283 estudantes na faixa de 15 a 29 anos no ano letivo de 2013 e descobriu que 19,3\% dos alunos de escola pública não gostariam de ter um colega de classe homossexual, travesti, transexual ou transgênero. Entre os entrevistados, 7,1\% não queriam ter travestis como colegas de classe, 5,3\% não queriam colegas homossexuais, 4,4\% não queriam colegas transexuais e 2,5\% não queriam ter colegas transgêneros. Esses índices de preconceito foram percebidos em maior quantidade no Ensino Médio, e mais entre os alunos do que entre as alunas. Enquanto 31,3\% dos rapazes declararam não desejar ter como colegas de classe pessoas LGBT, a proporção

${ }^{1}$ Disponível em: http://flacso.org.br/files/2015/11/LIVROWEB_Juventudes-na-escolasentidos-e-buscas.pdf. Acesso em: 20 jun. 2020. 
de meninas que assim se expressaram foi de apenas 8\% (ABRAMOVAY; CASTRO; WAISELFISZ, 2015).

Expõe-se de forma aterradora que a escola é um elemento ativo e reprodutor de rejeições sociais contra aqueles/as que vivenciam essências femininas e masculinas divergentes que atentam contra a heteronormatividade, incitando a perseguição contra os transgêneros e o não reconhecimento dos gays e das lésbicas como homens e mulheres de fato. (SILVA, 2016, p. 199200).

Essa rejeição social faz parte da trajetória educacional da população LGBT. Em junho de 2009, o MEC, por meio da Secretaria de Educação Continuada Alfabetização e Diversidade - SECAD - e o Instituto Nacional de Estudos e Pesquisas Educacionais - INEP - divulgou a Pesquisa Nacional Diversidade na Escola ${ }^{1}$, cujo resultado ${ }^{2}$ põe em destaque novamente a LGBTfobia ao demonstrar que $98,5 \%$ dos respondentes possuíam algum nível de distância social em relação a "homossexuais". Em relação aos demais grupos, os "homossexuais" receberam o segundo maior índice de rejeição, perdendo somente para os denominados "deficientes mentais", que acumularam 98,9\% de rejeição.

A "pedagogia heterossexual", heteronormativa por natureza, deslegitima discussões que reconheçam outras possibilidades de exercício da sexualidade porque estão restritas a um horizonte normativo no que diz respeito à matriz das sexualidades humanas. As sexualidades distintas do padrão socialmente esperado são permeadas pelo distanciamento e pela invisibilização. (LACERDA, 2018). Os resultados dessa

${ }^{1}$ A Pesquisa Nacional Diversidade na Escola foi uma pesquisa de campo iniciada em novembro de 2006 e aplicada em 501 escolas dos 27 estados brasileiros. A seleção das escolas respeitou a proporcionalidade das matrículas por região demográfica, localização da escola (capital e não-capital) e nível/modalidade de ensino (ensino fundamental, ensino médio e EJA). Estruturada em duas etapas, a primeira utilizou metodologia quantitativa e foi conduzida pelo Centro de Desenvolvimento e Planejamento Regional - CEDEPLAR - da Universidade Federal de Minas Gerais, enquanto a segunda, de caráter quantitativo, executada pela Fundação Instituto de Pesquisas Econômicas - FIPE - vinculada à Faculdade de Economia, Administração e Contabilidade - FEA - da Universidade de São Paulo, deu enfoque às questões de preconceito e discriminação no ambiente escolar no que diz respeito a gênero, raça, orientação sexual, idade, origem, deficiência e condição socioeconômica. Ao todo, foram consultados 18.599 respondentes de cinco diferentes públicos, assim distribuídos: 15.087 estudantes; 1.004 professores(as) de português e matemática; 501 diretores(as) de escolas; 1.005 profissionais de educação; e 1.002 pais, mães e responsáveis, membros do Conselho Escolar ou da Associação de Pais e Mestres.

2 Disponível em: http://portal.mec.gov.br/pnaes/194-secretarias-112877938/secad-educacaocontinuada-223369541/13917-pesquisa-diversidade-na-escola. Acesso em: 20 jun. 2020. 
deslegitimação e da heteronormatividade são demonstrados em todas as pesquisas voltadas para as percepções da população LGBT sobre o ambiente escolar, como, por exemplo, a pesquisa realizada pelo Núcleo Jurídico de Diversidade Sexual e de Gênero da Universidade Federal de Minas Gerais (Diverso) com os participantes da 19a Parada do Orgulho LGBT de Belo Horizonte ${ }^{1}$, em 2016:

Quando perguntadas/os se já haviam sido vítimas de algum tipo de constrangimento no ambiente escolar, 100\% das travestis, e $76 \%$ das mulheres transgênero afirmaram que sim, enquanto $51 \%$ das mulheres cisgênero não-heterossexuais, e $64 \%$ dos homens cis-gênero não-heterossexuais reportaram ter sofrido alguma forma de discriminação. Além disso, 15\% das mulheres cisgênero heterossexuais também afirmaram já ter sofrido discriminação no ambiente escolar, enquanto nenhum homem cisgênero heterossexual respondeu $\operatorname{sim}$ a esta pergunta. (DIVERSO, 2017, p. 6-7).

Os números mostram que "os estudantes aprendem cedo a mover alavancas do heterossexismo" e da LGBTfobia, como destaca Junqueira (2016, p. 108-109). O espaço que deveria ser dedicado ao conhecimento torna-se, nesses casos, um lugar de censura, violência, vergonha e medo, marcado pelo silenciamento, pela invisibilização, pela desqualificação e pelas diversas exclusões.

Em 2016, a Associação Brasileira de Lésbicas, Gays, Bissexuais, Travestis, Transexuais e Intersexos (ABGLT) divulgou os resultados da "Pesquisa Nacional sobre o Ambiente Educacional no Brasil 2015: as experiências de adolescentes e jovens lésbicas, gays, bissexuais, travestis e transexuais em nossos ambientes educacionais" ${ }^{2}$. 0

${ }^{1}$ A 19a Parada do Orgulho LGBT de Belo Horizonte aconteceu no dia 17 de julho de 2016 e levou cerca de 60 mil pessoas às ruas da capital mineira. Nessa oportunidade, o Diverso entrevistou 396 pessoas para conhecer melhor o perfil dos frequentadores do evento e divulgou os resultados no site do grupo na internet: http://www.diversoufmg.com/publica--es.html. Acesso em: 20 jun. 2020.

2 Trata-se da primeira pesquisa nacional virtual realizada no Brasil com adolescentes e jovens LGBT sobre as experiências que viveram nas instituições educacionais relacionadas a sua orientação sexual e/ou identidade/expressão de gênero. Para fins de comparação, a pesquisa também foi realizada, simultaneamente, em outros cinco países latinoamerocanos (Uruguai, Argentina, Chile, Peru, Colômbia), com o objetivo de produzir dados capazes de fundamentar políticas públicas que possibilitem transformar as instituições educacionais em ambientes mais seguros e acolhedores para estudantes LGBT. O questionário, disponibilizado online, recebeu 1016 respostas de adolescentes entre 13 e 21 anos que se autoidentificaram como LGBT, com relatos de violências de todos os tipos. (ABGLT, 2016, p. 13). Foi obtida representatividade em termos de regionalidade e também em termos das Unidades Federativas (UF). Das 27 unidades federativas, apenas o Tocantins não teve respondentes. (ABGLT, 2016, p. 69). 
resultado, disponibilizado online, demonstra um cenário caracterizado pela insegurança dos estudantes LGBT nas instituições educacionais, com alta incidência de violências, sem o devido apoio ou medidas para contornar essas situações, e sem um número adequado de profissionais de educação capacitados para lidar com essas situações por meio de ações educativas (ABGLT, 2016).

Perguntados sobre a frequência com que ouviam comentários LGBTfóbicos, 47,5\% dos estudantes LGBT relataram ter ouvido outros estudantes fazerem comentários pejorativos frequentemente ou quase sempre. Além disso, 21,7\% deles relataram que esses comentários eram feitos pela maioria dos seus colegas e 69,1\% disseram já ter ouvido comentários LGBTfóbicos feitos por professores e funcionários das escolas. Sobre os comentários dos colegas, a maioria afirmou que foram feitos na ausência de professores e funcionários (no entanto, cerca de um quarto dos estudantes afirmou que os profissionais estavam presentes "sempre" ou "a maioria das vezes"). (ABGLT, 2016).

A maioria dos profissionais não intervinha quando ocorriam comentários dessa natureza. Apenas $16,1 \%$ dos respondentes relataram a tomada de providências por parte dos profissionais na "maioria das vezes" ou "sempre", enquanto 53,9\% informaram que os profissionais "nunca" tomavam providências. Além disso, poucos estudantes relataram reações de seus colegas: $25,6 \%$ afirmaram que seus pares intervinham sempre ou na maioria das vezes quando ouviam comentários LGBTfóbicos e $36,2 \%$ disseram que seus pares nunca tomavam qualquer providência. ( $A B G L T, 2016)$.

Para os estudantes, a grande repetição de comentários LGBTfóbicos contribui para um ambiente hostil, enquanto a inércia da equipe de profissionais passa a mensagem de que a LGBTfobia é tolerada. Além disso, a prática desses comentários por parte dos professores inspira e serve de modelo para os demais estudantes. A convivência direta com a ocorrência de comentários discriminatórios cria um ambiente negativo de aprendizagem e ainda pode contribuir para que os estudantes LGBT não se sintam seguros na instituição educacional. (ABGLT, 2016).

Outra ideia aqui discutida é corroborada por dados dessa pesquisa, segundo a qual mais da metade dos estudantes LGBT relataram ter ouvido, muitas vezes ou frequentemente, comentários sobre "não ser masculino o suficiente" (56,8\%) ou "não ser feminina o suficiente" (51\%), sendo maior a perseguição quando o comportamento 
"desviante" é relacionado ao feminino. Quando perguntados sobre a origem desses comentários, 27,2\% relataram vir da maioria de seus pares, e 24,3\% relataram já terem ouvido "frequentemente" ou "quase sempre" esses tipos de comentários feitos pela equipe profissional. (ABGLT, 2016).

Ainda sobre comentários relativos à identidade de gênero, 54,7\% dos respondentes afirmaram ter ouvido, "frequentemente" ou "quase sempre", comentários negativos especificamente sobre pessoas trans. Além disso, entre essas pessoas, 68\% dos respondentes afirmaram já terem sido agredidos verbalmente na instituição educacional por causa de sua identidade/expressão de gênero e 23,5\% relataram ter sofrido isso "com frequência" ou "quase sempre". Em relação à orientação sexual, $72,6 \%$ já foram verbalmente agredidos e $22,8 \%$ sofreram essa forma de agressão "quase sempre" ou "frequentemente". (ABGLT, 2016).

Em relação às agressões físicas, $26,6 \%$ relataram ter sofrido agressão física na instituição educacional por causa de sua orientação sexual, e 6\% informaram que isso ocorreu "frequentemente" ou "quase sempre". Em virtude da identidade/expressão de gênero, 24,6\% foram agredidos fisicamente e 5,7\% vivenciavam essa agressão "frequentemente" ou "quase sempre". (ABGLT, 2016).

Perguntados sobre a frequência em que recebiam agressões ou ameaças verbais por meio de redes sociais (prática identificada como cyberbullying), 34,7\% dos respondentes informaram ter vivenciado este tipo de agressão no último ano e 7,7\% afirmaram ter vivido isso "frequentemente" ou "quase sempre". (ABGLT, 2016).

Como afirma Junqueira (2016), ambientes escolares que produzem e alimentam discriminações tendem a comprometer o rendimento escolar dos alunos discriminados. E a pesquisa não mostrou resultado diferente. Os estudantes LGBT afirmaram obter notas significativamente inferiores às daqueles que sofriam menos manifestações de violência. Por exemplo, $80,2 \%$ dos estudantes LGBT que vivenciavam níveis menores de agressão verbal devido à orientação sexual afirmaram ter notas boas ou excelentes, enquanto, entre os que vivenciavam níveis maiores de agressão, esse número é de apenas 72,4\%. (ABGLT, 2016).

Por último, 59,7\% dos entrevistados que alegaram vivenciar níveis menores de discriminação por causa de sua orientação sexual indicaram um sentimento positivo de pertencimento à instituição educacional. Entre os alunos que relataram vivenciar 
discriminações mais severas em razão da orientação sexual, esse índice é de apenas 21,2\%. (ABGLT, 2016).

A naturalização da violência contra estudantes LGBT transforma o espaço escolar num ambiente de repulsa a todas as identidades não hegemônicas. Muito mais que não conseguir se organizar enquanto espaços de proteção da diversidade, as escolas por vezes tornam-se espaços de repetição de sofrimentos e manutenção de violências. A Ordem dos Advogados do Brasil (subseção Mato Grosso) divulgou uma pesquisa nacional ${ }^{1}$ que aponta um índice de $82 \%$ de evasão escolar de travestis e transexuais em 2016 e segundo a qual 19,3\% dos alunos de escola pública entre 15 e 29 anos não gostariam de ter um colega de classe LGBT. E a escolaridade é, hoje, um dos fatores mais determinantes no nível de preconceito e aceitação da população em relação a pessoas LGBT.

\section{CONSIDERAÇÕES FINAIS}

Os dados e desenvolvimentos teóricos aqui apresentados têm como finalidade demonstrar os contextos de exclusões vivenciados por pessoas LGBT em relação ao ambiente escolar e que culminam em índices tão baixos de escolaridade e tão altos de evasão escolar.

Como visto, grande parte das pesquisas buscou investigar e referir-se à população LGBT como um todo, sem um recorte específico, mas é sabido que há variações quando se tratam das diversas identidades que compõem a sigla. Essa homogeneização é resultado da ainda menor visibilidade que alguns grupos recebem em relação a outros, mesmo dentro dos movimentos $L G B T$, como é o caso das pessoas trans, que acumulam os piores índices e os menores acessos.

Especificamente no campo da educação, no entanto, essa ausência de dados pode se justificar também pelo distanciamento entre a educação formal e as pessoas LGBT. Em contrapartida, nos estudos da diversidade, o campo de conhecimentos relativos à educação é, sem dúvida, uma referência no nosso país.

${ }^{1}$ Disponível em: http://flacso.org.br/files/2015/11/LIVROWEB_Juventudes-naescola-sentidos-e-buscas.pdf. Acesso em: 20 jun. 2020. 
É importante, por derradeiro, que se registre a importância que o conhecimento e a análise das interseccionalidades têm no tratamento da população LGBT. Uma série de fatores e dados alteram-se consideravelmente quando recortados a partir de outras variáveis, como gênero, classe e raça. As pessoas LGBT estão dispersas por todos os grupos (sociais, econômicos, étnicos e etc.) e, é claro, sofrem discriminações e enfrentam exclusões também diversificadas em decorrência desses indicadores.

\section{REFERÊNCIAS}

ABGLT (ASSOCIAÇÃO BRASILEIRA DE LÉSBICAS, GAYS, BISSEXUAIS, TRAVESTIS E TRANSEXUAIS). Pesquisa Nacional sobre o Ambiente Educacional no Brasil 2015: as experiências de adolescentes e jovens lésbicas, gays, bissexuais, travestis e transexuais em nossos ambientes educacionais. Curitiba: Secretaria de Educação. ABGLT, 2016.

ABRAMOVAY, Miriam; CASTRO, Mary Garcia; WAISELFISZ, Júlio Jacobo. Juventudes na escola, sentidos e buscas: Por que frequentam? Brasília-DF, Flacso, OEI, MEC, 2015. Disponível em: http://flacso.org.br/files/2015/11/LIVROWEB Juventudesna-escola-sentidos-e-buscas.pdf. Acesso em: 20 jun. 2020.

BORTOLINI, Alexandre Silva. "Diversidade sexual e de gênero na escola - Uma perspectiva Intercultural e Interrelacional". Revista Espaço Acadêmico (UEM), ano XI, n. 123, p. 27-37, 2011.

CARVALHO, José Murilo de. Cidadania no Brasil: o longo caminho. 23a ed., Rio de Janeiro, Civilização Brasileira, 2017.

CORTINA, Adela. Cidadãos do mundo: para uma teoria da cidadania. Trad.: Silvana Cobucci Leite. São Paulo, Edições Loyola, 2005.

DALLARI, Dalmo de abreu. Direitos humanos e cidadania. 2. ed. reform., São Paulo, Moderna, 2004.

DIVERSO (Núcleo Jurídico de Diversidade Sexual e de Gênero - UFMG). Relatório da 19a Parada do Orgulho LGBT de Belo Horizonte, 2017. Disponível em: http://www.diversoufmg.com/publica--es.html. Acesso em: 20 jun. 2020.

FACCHINI, Regina. Sopa de letrinhas? Movimento homossexual e produção de identidades coletivas nos anos 90. Rio de Janeiro, Garamond, 2005.

GOMÀ, Ricard. Processos de Exclusão e Políticas de Inclusão Social: Algumas Reflexões Conceituais. In: C. B. CARNEIRO; B. L. D. COSTA. Gestão Social: o que há de novo? Belo Horizonte, Fundação João Pinheiro, 2004.

JUNQUEIRA, Rogério Diniz. Pedagogia do Armário. CULT - Revista Brasileira de Cultura, n. 202, ano 18, 2015. 
JUNQUEIRA, Rogério Diniz. Pedagogia do Armário: uma conjugação entre heteronormatividade, cotidiano e currículo Escolar. In: NEVES, André Luiz Machado das; CALEGARE, Fernanda Priscilla Pereira; SILVA, Iolete Ribeiro (Orgs.), Escola, sexualidade e gênero: perspectivas críticas, Manaus, UEA Edições, 2016.

LACERDA, Milena. Enredos sobre diversidade sexual e gênero na educação. In: L. NOGUEIRA; E. HILÁRIO; T. T. PAZ; K. MARRO. Hasteemos a bandeira colorida: diversidade sexual e de gênero no Brasil, São Paulo, Expressão Popular, 2018.

LOURO, Guacira Lopes. Gênero, sexualidade e educação: uma perspectiva pósestruturalista. Petrópolis, Vozes, 1997.

MARSHALL, Thomas Humprey. Cidadania, Classe Social e Status. Rio de Janeiro, Zahar Editores. 1967.

MIRANDA, Camila de Almeida. O papel do educador na consolidação da dignidade da pessoa humana e no respeito à diversidade. In: M. BROCHADO; M. F. M. GOMES; N. LIPOVETSKY. Educação para direitos humanos: diálogos possíveis entre a pedagogia e o direito, v. II, Belo Horizonte, Editora UFM, 2016.

NEVES, André Luiz Machado das; CALEGARE, Fernanda Priscilla Pereira; SILVA, lolete Ribeiro. Escola, identidade de gênero e transexualidade: reflexões a partir da antropologia do corpo. In: NEVES, André Luiz Machado das; CALEGARE, Fernanda Priscilla Pereira; SILVA, Iolete Ribeiro (Orgs.). Escola, sexualidade e gênero: perspectivas críticas, Manaus, UEA Edições, 2016.

PEDRA, Caio Benevides. Acesso a cidadania por travestis e transexuais no Brasil: um panorama da atuação do Estado no enfrentamento das exclusões. 2018. Dissertação (Mestrado em Administração Pública) - Escola de Governo Professor Paulo Neves de Carvalho - Fundação João Pinheiro, Belo Horizonte, 2018.

ROTONDANO, Erica Vidal. Corpos, gêneros, sexualidades e educação: uma reflexão. In: NEVES, André Luiz Machado das; CALEGARE, Fernanda Priscilla Pereira; SILVA, lolete Ribeiro (Orgs.), Escola, sexualidade e gênero: perspectivas críticas, Manaus, UEA Edições, 2016.

SILVA, Paulo Henrique Barbosa. Invisibilidade transgênera na escola e a incipiente visibilidade nas artes cênicas e literatura infanto-juvenil homossexual. In: M. BROCHADO; M. F. M. GOMES; N. LIPOVETSKY. Educação para direitos humanos: diálogos possíveis entre a pedagogia e o direito. Vol. 2, Belo Horizonte, Editora UFMG, 2016.

TORRES, Marco Antonio. A diversidade sexual na educação e os direitos de cidadania LGBT na escola. Belo Horizonte, Autêntica Editora, 2013.

VIDAL, Haroldo. Crianças e sexualidade: saberes-fazeres produzidos dentro-fora das escolas. Vitória, Cousa, 2017. 
ZAGO, Luiz Felipe; GUIZZO, Bianca Salazar. Gênero, Sexualidade e Escola: o que temos a ver com isto?. In: NEVES, André Luiz Machado das; CALEGARE, Fernanda Priscilla Pereira; SILVA, lolete Ribeiro (Orgs.). Escola, sexualidade e gênero: perspectivas críticas, Manaus, UEA Edições, 2016. 


\section{CAPÍtULO VI}

\section{SEXUALIDADE NOS ESPAÇOS ESCOLARES: UMA ABORDAGEM CRÍTICA DO ATUAL CENÁRIO EDUCACIONAL}

Zilanda Souza dos Santos ${ }^{1}$

Walmir Fernandes Pereira ${ }^{2}$

\footnotetext{
${ }^{1}$ Graduanda do curso de Pedagogia. Universidade Federal do Estado do Rio de Jan eiro - UNIRIO

${ }^{2}$ Mestrando em Tecnologias Emergentes em Educação. MUST University - Flórida - EUA
}

\section{RESUMO}

O trabalho buscou responder se cabe à escola oferecer a prática de valores de igualdade e respeito entre pessoas independente do sexo permitindo que a criança conviva com todas as possibilidades relacionadas ao papel do homem e da mulher. Além disso, teve como objetivo analisar de maneira crítica a sexualidade nos espaços escolares no atual cenário educacional e ainda refletir sobre a sexualidade em si, para que fosse possível entender os desafios e possibilidades da igualdade de gêneros no âmbito escolar. A sexualidade é considerada uma construção social, relacionada a múltiplos modos de sentir, de desejar e de se relacionar e manifestam na sociedade, onde aspectos biológicos condicionam parcialmente essa sexualidade, proporcionando fisiologia e morfologia do corpo às condições prévias para essa construção. Dessa forma, ela pode surgir de acordo com o contexto cultural, influenciado por múltiplas variáveis, tais como: psicológico, idade, socioeconômico, sexo biológico, papel de gênero, etnia, por isso é necessário um amplo reconhecimento e respeito pela a variabilidade de formas, crenças e comportamentos sexuais relacionados à nossa sexualidade. Desse modo, a educação sexual é necessária, não em sentido a ensinar a criança, ou adolescente sobre a sexualidade de cada indivíduo, mas sim, possibilitar esclarecimentos científicos sobre a sexualidade e ainda dialogar com o sentido de conscientizar sobre o tema. A escola é o lugar privilegiado de promoção de cultura e de acolher e reconhecer a pluralidade das identidades e dos comportamentos independente da diferença. Os principais autores utilizados neste trabalho foram: Arán (2006), Bordini (2009), Furlanetto (2018), Lins (2016), Mello (2004) e Mayer (2013), denominando assim uma pesquisa bibliográfica.

Palavras-chave: Escola. Gênero. Pluralidade. Sexualidade.

\section{INTRODUÇÃO}

O trabalho traz uma temática bem desafiadora para o cenário educacional atual, uma vez que falar de sexualidade no âmbito escolar ainda é considerado um tabu, tanto para alguns profissionais da educação quanto para os pais. Vale ressaltar que orientação sexual nas escolas tem como finalidade prevenir uma gravidez precoce, o uso de drogas 
e doenças sexualmente transmissíveis.

A escolha do tema se justifica pela importância do assunto na atual sociedade em que estamos vivendo. Por ser uma questão que requer um estudo mais aprofundado, visto que a sociedade cria estereótipos de gênero, e os indivíduos são inseridos nesses contextos desde criança, sendo fruto do seu meio, naturalizam comportamentos de desigualdade como sendo naturais, ainda que não sejam.

Considerando que a escola vem sendo a segunda principal instituição da qual a criança tem acesso, acaba reforçando muitas dessas desigualdades. Cabe à escola dispor de ambientes e profissionais que possibilitem a prática de valores de igualdade e respeito entre pessoas de sexos diferentes e permita que a criança conviva com todas as possibilidades relacionadas ao papel do homem e da mulher.

O objetivo geral deste trabalho é analisar de maneira crítica a sexualidade nos espaços escolares no atual cenário educacional. Seguido dos objetivos específicos: Refletir sobre a sexualidade, identificar os desafios e possibilidades da igualdade de gêneros no âmbito escolar e reconhecer o papel da família no desenvolvimento da sexualidade de seus filhos.

A metodologia utilizada no trabalho foi à pesquisa bibliográfica através de leituras em livros, sites eletrônicos e artigos publicados acerca do assunto em questão.

\section{REFERENCIAL TEÓRICO}

\subsection{Refletindo sobre a Sexualidade}

A adolescência é uma fase crítica da vida, caracterizada por transições bem fundamentadas no comportamento emocional, intelectual, sexual e social dos seres humanos. Sua principal tarefa é a consolidação de sua própria identidade, é descobrir quem somos.

Na fase da adolescência, a amizade se torna de vital importância, pois o adolescente busca o hábito com o mesmo espírito, com o qual pode compartilhar as experiências vividas no processo de busca de identidade. Por esse motivo, a sexualidade exige qualidades de inteligência e generosidade. Ambos estão ligados ao desenvolvimento pleno e integral da personalidade do sujeito que merece ser bem tratado na família, social e cultural, a fim de criar nos adolescentes uma sexualidade 
saudável, harmoniosa e responsável, capaz de funcionar no ambiente em que se desenvolve. A seleção deste tópico tem sido de grande interesse e de grande importância, pois nos permitiu conhecer e avaliar as diferentes situações de risco expressas por adolescentes com relação à sexualidade, bem como a ignorância sobre o assunto e a finalidade do mesmo. Uma vez que um melhor conhecimento sobre sexualidade é menos problemático em adolescentes.

A sexualidade é uma parte importante, agradável e natural da vida. É uma forma de comunicação e uma fonte de prazer, saúde e ternura que se expressa em abraços, beijos, olhares, gestos e mimos. À medida que a pessoa cresce e se desenvolve, a maneira de expressar a sexualidade diversifica e se intensifica. Porque muitos adolescentes não têm sua sexualidade bem definida e, portanto, seus direitos são violados, pois, como pessoas, eles têm o direito de praticar a sexualidade em sua própria consciência, sentimentos em relação ao próprio corpo e aos outros. Assim como a capacidade e a necessidade de se sentir bem emocionalmente com outra pessoa.

Pode-se dizer que existem muitos fatores que limitam o adolescente a praticar a sexualidade, tais como: violência doméstica, fatores socioculturais, pois esses fatores causam ao estudante: estresse, baixa autoestima, desconfiança, insegurança consigo e com os outros. Através deste estudo sobre sexualidade em adolescentes, tentaremos detectar, com sugestões ou recomendações aos pais, adolescentes e comunidade em geral, com o objetivo de promover até um índice de adolescentes que praticam a sexualidade no espaço em que se desenvolvem.

Para se referir à educação sexual e sexualidade em adolescentes e crianças, é pertinente considerar primeiro o conceito por sexualidade e saúde sexual e reprodutiva (SRH). A sexualidade em geral é considerada uma construção social, relacionada aos múltiplos e intrincados modos pelos quais nossas emoções, desejos e relacionamentos são expressos na sociedade em que vivemos, onde aspectos biológicos condicionam parcialmente essa sexualidade, proporcionando fisiologia e morfologia do corpo às condições prévias para essa construção. A sexualidade de cada um de nós surge e existe em um contexto cultural, influenciado por múltiplas variáveis, tais como: psicológico, idade, socioeconômico, sexo biológico, papel de gênero, etnia, por isso é necessário um amplo reconhecimento e respeito pela a variabilidade de formas, crenças e comportamentos sexuais relacionados à nossa sexualidade (SOUZA, 2014). 
A educação sexual de adolescentes, como parte do currículo escolar, é uma tarefa realizada há alguns anos em diferentes países. Tradicionalmente, supõe-se que esse tipo de educação deva ser dado na família, como parte de sua responsabilidade natural. No entanto, os esforços desenvolvidos por diferentes países em todas as partes do mundo não deram os resultados esperados em termos de redução de gestações em idade precoce ou taxas de doenças transmissíveis sexualmente entre os jovens.

Como aponta Figueiró (2006), faz-se necessário a educação sexual, não em sentido a ensinar a criança, ou adolescente sobre o que cada um é, mas sim, possibilitar esclarecimentos científicos acerca da sexualidade; medidas que dialogam com o aspecto de conscientização, tratado por diversos autores, como Paulo Freire (1975), e documentos nacionais - assim como internacionais.

Parte-se do documento que diz respeito ao próprio comportamento da escola, seu corpo de profissionais e professores, a Lei de Parâmetros Curriculares Nacionais de 1997 - que trata acerca da Orientação Sexual. A respeito disto, se estabelece a discussão proposta por Nunes (2005, p. 17 e 18), onde o mesmo esclarece uma discussão acerca de duas interpretações acerca do Orientar. Nunes ao analisar o documento, propõe que esta orientação é no sentido educativo, ou seja, em relação à educação sexual, com objetivos de conscientização.

Pode-se partir do que escreve Figueiró:

Fazer com que os educadores entendam que a principal razão para desenvolvê-la nas escolas é o direito que a criança e o adolescente têm de conhecer seu corpo e a sexualidade, com uma visão positiva dessas realidades, e a necessidade de rever e transformar as formas de relação afetivo-sexual entre duas pessoas sejam elas de sexo diferente ou igual. (FIGUEIRÓ 2006, p. 58).

A educação sexual tem sido motivos de muitas discussões importantes ao ambiente escolar, e a comunidade acadêmica. Por ser um tema complexo, parte-se do proposto em documentos relativos ao andamento da educação, seus parâmetros e perspectivas sobre assuntos como a inclusão e diversidade.

Como aponta Silva (1996), a escola possui como objetivo principal, a atividade de esclarecimento que é a preparação do indivíduo para sua vivência em sociedade. Neste sentido, não somente cabe a escola o dever de passar o conhecimento dos 
espíritos científicos, como também, cabe a mesma fazer do indivíduo um cidadão capaz de exercer seus direitos e deveres, de forma conscientizada.

Sobre isto, pode-se partir do que entende a CONAE (2010), onde expressa ser o ambiente escolar um:

(...) espaço democrático de construção de acordos entre atores sociais, que, expressando valores e posições diferenciadas sobre os aspectos culturais, políticos, econômicos, apontam renovadas perspectivas para a organização da educação nacional e para a formulação do Plano Nacional de Educação 2011-2020. (CONAE, 2010, p. 9).

Neste sentido, como aponta Mello (2004), é dever da escola cumprir com os principais paradigmas propostos em documentos nacionais, e internacionais. A Declaração de Salamanca (1994), que propõe o ensino enquanto inteiramente inclusivo, onde a escola é vista de forma versátil, adaptando-se as necessidades dos alunos, sendo estas não somente física, mas também, psicológicas, comportamentais e sociais.

Pode-se dizer, portanto, que, a relação entre escola e aluno deve se dá de forma respeitosa, em que a escola deve respeitar as diferenças culturais, sociais e pessoais de cada aluno. Isto é, a escola deve respeitar a orientação sexual a qual o aluno se coloca.

Segundo Bordini (2009), esta é uma nova visão sobre o ambiente escolar que, antes, foi visto enquanto um espaço doutrinador e de disciplina, que, sobretudo, deveria ditar as regras ligadas aos aspectos mais conservadores da sociedade, como a orientação heterossexual enquanto regra. Esta visão da escola enquanto manutenção do status quo, foi, principalmente, adquirida durante a Ditadura Civil Militar onde:

Nos anos finais da década de 1960 , com a instauração do Ato Institucional número 5 e do Ato Institucional número 6, a ditadura militar tornou-se mais rígida e violenta, e os órgãos oficiais da educação assumiram uma postura ainda mais moralista e autoritária, proibindo qualquer ação que se referisse ao sexo e sua educação no âmbito da escola. (BORDINI 2009, p. 37).

Com o estabelecimento da redemocratização brasileira, o avanço das discussões da educação enquanto agente socializador e sua práxis de gestão democrática, a escola passou adotar posturas diferentes ao moralismo, sobretudo adotando perspectivas que tentavam trazer os primeiros passos para uma educação sexual. 
Em 1998, o PCN - Plano Nacional da Educação define as primeiras linhas de atuações ao trabalho de educação sexual nas escolas, entendendo ser melhor tratar deste assunto por duas vias: extracurricular e curricular.

O trabalho da orientação sexual deverá, portanto ser de duas formas: dentro da programação, por meio de conteúdo já transversalizado nas diferentes áreas do currículo, e extraprogramação, sempre que surgiram questões relacionadas ao tema (BRASIL 1998, p. 309).

Para tanto, visando encurtar as distâncias entre a teoria e a prática dentro das salas de aula, foi criado o Diversidade e Educação (GDE), que possui a proposta de trazer informações sobre a diversidade nas escolas, sendo esta em sentidos do gênero, orientação sexual e relações étnico-raciais.

Ainda, pouco se entende sobre as relações de gênero por completo. Como aponta Lins, Machado e Escoura (2016), há uma compreensão muito superficial das questões de gênero na escola, pensa-se somente nas questões de heterossexualidade, homossexualidade, e o papel da escola para com estes assuntos.

Entretanto, a educação sexual não se trata apenas sobre isto, mas das relações que os alunos desenvolvem e que são atravessadas pela sexualidade, os estigmas e construções sociais sobre esta mesma. Os autores citados acima levantam a discussão acerca das cores, por exemplo, e suas relações com os estigmas da sexualidade.

A cor rosa e azul foram atribuídas cada uma a um determinado gênero, e assim desenvolvendo preconceitos sociais que se respaldam na homossexualidade e machismo. Como aponta Silva (1996), isto deve ser combatido nas escolas porque, além de ser baseado em fatos infundados, dão origem a formas de discriminações sociais que podem se desenvolverem para tipos de agressões - vão em contrapartida as perspectivas da escola, na formação de indivíduos capazes de viverem em sociedade com indivíduos destoantes dos próprios.

Neste sentido, cabe à escola promover medidas capazes de alçarem os conhecimentos necessários aos alunos, mesmo que estes possuam um histórico familiar de preconceitos e discriminações. Como bem aponta a Constituição Federal (1988), a orientação sexual é uma das liberdades que se reflete na categoria de direito social 
assegurado pelo estado brasileiro. E claro este direito social é também influência aos direitos civis e políticos.

Assim, cabe ressaltar o papel da escola com a pluralidade e o desejo do aspecto democrático assegurado a todos:

\begin{abstract}
A escola e, em particular, a sala de aula, é um lugar privilegiado para se promover a cultura de reconhecimento da pluralidade das identidades e dos comportamentos relativos a diferenças. Daí, a importância de se discutir a educação escolar a partir de uma perspectiva crítica e problematizadora, questionar relações de poder, hierarquias sociais opressivas e processos de subalternização ou de exclusão, que as concepções curriculares e as rotinas escolares tendem a preservar. (SILVA, 1996, p. 49).
\end{abstract}

Com base no exposto, surgem como necessidade os serviços de educação sexual e assistência integral, constituindo pilares fundamentais para o desenvolvimento de cada indivíduo, adquirindo especial relevância quando abordamos a questão da sexualidade do adolescente. É indiscutível a necessidade de promover a aplicação de programas de educação sexual de forma integral e transversal nos estabelecimentos escolares.

\title{
2.2 Desafios e Possibilidades da igualdade de gêneros no âmbito escolar
}

Para escrever sobre a diversidade de gênero, e preciso antes entender que Gênero, identidade afetivo-sexual e sexo biológico, são assuntos interligados, mas que não querem dizer a mesma coisa e por essa razão tendem a ser confundidos.

O sexo biológico é como o nome diz definido pelo corpo orgânico. Segundo Arán (2006) é definido pelo órgão reprodutivo, que já vem programado e fixo, podendo ser o pênis, a vagina ou até ambos.

A Identidade Afetivo-sexual, termo utilizado para substituir orientação sexual e que segundo Jesus (2012), aponta a maneira como nos relacionamos afetiva e sexualmente com outras pessoas.

Este é um debate atual e que gera desconforto, porque envolvem questões religiosas, ideológicas e até políticas, ainda mais se tratando de se devemos ou não tratar disso dentro das escolas. Porém, este assunto está interligado diretamente a luta das mulheres por igualdade, uma vez que segundo Louro (1997), foi graças aos primeiros 
movimentos feministas que essa discussão surgiu e começou a ser pauta, ainda que até hoje gere confusão.

Segundo Meyer (2013) isso se deu em meados do século XIX, com um grupo de mulheres que se organizou para reivindicar o direito ao voto e ficou conhecido como as sufragistas. O movimento feminista está dividido por "ondas". Sendo A primeira acontecendo nesse primeiro momento entre o século XIX até o início do XX e com o objetivo ligados a organização da família, oportunidade de estudo ou acesso a determinadas profissões e foi seguido de uma acomodação por parte do movimento (LOURO, 1997). Já a segunda onda teve inicio no final da década de 1960 e foi marcado pelas preocupações sociais e políticas, além disso, também pela problemática das questões do conceito de gênero (Ibid., 1997).

No entanto essas questões passaram a ser discutida nos anos 1980, sofrendo influência de pensadores como Foucault e Derrida, a ideia de "[...] que as subjetividades são construídas pelos discursos, em um campo que é sempre dialógico e intersubjetivo" (NARVAZ; KOLLER, 2006). Este período ficou marcado como sendo a terceira onda do feminismo e foi marcado pelas influencias no sentido das discussões voltadas para as noções de corpo e sobre a sexualidade e servem de referência ainda hoje.

[...] essa proposta concentra-se na análise das diferenças, da alteridade, da diversidade e da produção discursiva da subjetividade. Com isso, desloca-se o campo do estudo sobre as mulheres e sobre os sexos para o estudo das relações de gênero. Neste sentido é que algumas posições, ainda que heterogêneas, distinguem os Estudos Feministas - cujo foco se dá principalmente em relação ao estudo das e pelas mulheres, mantidas as estreitas relações entre teoria e políticamilitância feminista - dos Estudos de Gênero. [...] "nesta terceira fase do movimento feminista, observa-se intensamente a intersecção entre o movimento político de luta das mulheres e a academia, quando começam a ser criados nas universidades". (NARVAZ; KOLLER, 2006, p. 649).

Foi a partir desse movimento que o lugar social da mulher passou a ser questionado e a partir disso, outras questões, interligadas a essa, passaram a ser discutidas, uma vez que a mulher passou a não aceitar mais o seu lugar de inferioridade por questões biológicas. 
Simone de Beauvoir (1967, p. 9) destaca de sobre gênero, escreveu a frase, "não se nasce mulher: torna-se mulher", o que levantou a hipótese de que mais do que as questões biológicas, a identidade de gênero homem/mulher é parte de uma construção social a partir de uma identificação com papéis existentes. Sendo assim, podemos entender que uma identidade de gênero surge ao longo da nossa construção como pessoa e a partir de aspectos disponíveis na sociedade e de identificação com papeis femininos e ou masculinos disponíveis. É nesse conviver e construir-se, que um indivíduo vai assumir pra si um papel.

Para Tilio (2009) nossa identidade é construída a partir das nossas relações sociais, e diferente do que se acreditava, não podem ser definidas pela biologia e nem tão pouco são fixas e pré-determinadas, a identidade é fluída.

A partir do que foi exposto até aqui, é possível entender que uma das razões para que surjam ideias e as desigualdades de gênero, são os equívocos construídos a partir do desconhecimento de conceitos e da concepção de que existe uma superioridade biológica por parte do gênero masculino e que por essa razão, as mulheres estão relegadas a segundo plano dentro da sociedade. Essa ideia que parte da concepção de que como seriam biologicamente superiores. Sendo os homens por essa razão além de mais fortes, mais inteligentes e melhores em áreas que exigem essas características e as mulheres cabe então o cuidado dos filhos, trabalhos delicados e que não exigem tão raciocínio.

No texto "Diferentes, não desiguais", Machado e Escoura (2016) apontam para como as instituições das quais convivemos e que fazem parte da nossa construção como indivíduo, determinam e colaboram para que essas concepções e diferenças sem reforçadas. Na escola, por exemplo, desde pequeno somos divididos em grupos de meninas e meninos. Assim como nas atividades que realizamos. Ou seja, desde pequeno "Percebemos rapidamente que o mundo é dividido entre feminino e masculino e aprendemos também em qual dos dois lados devemos estar" (Ibid., p. 9).

Para Machado e Escoura (2016):

Gênero, como compreendemos, é um dispositivo cultural, constituído historicamente, que classifica e posiciona o mundo a partir da relação entre o que se entende como feminino e masculino. É um operador que cria sentido para as diferenças percebidas em nossos corpos e 
articula pessoas, emoções, práticas e coisas dentro de uma estrutura de poder (p. 9).

As ideias sobre gênero que circular pela sociedade influenciam e determina toda nossa vida. Além disso, criam expectativas a respeito de como devemos agir, do que pensar e do que gostar e até normas a respeito disso. Regras de gênero são concepções a respeito de como homem e mulheres devem se comportar. Por exemplo, meninos vestem azuis e meninas vestem rosa. Meninas não jogam futebol, são péssimas motoristas. Homem não arruma casa, não cuida dos filhos e etc. Criam além de regras, expectativas sobre o que esperar de cada um. Uma mulher não pode gostar de futebol, uma vez que isso é coisa de homem, logo, um homem não pode gostar de cuidar da casa ou dos filhos, já que esse é papel da mulher. Quando fazemos isso, segundo Machado e Escoura (2016, p. 15) “[...] quando associamos um comportamento específico a um grupo de pessoas só porque são mulheres, homens, meninas ou meninos, estamos reproduzindo alguns estereótipos de gênero". Ainda para as autoras (Ibid., 2016), essas regras além de serem restritivas, uma vez que tentam encaixar as pessoas em estereótipos sociais é a razão de muitas situações de desigualdade. O termo desigualdade de gênero marca essa relação de poder, privilégio e de hierarquia social que existe entre homens e mulheres.

O mundo esta sempre buscando respostas que justifiquem as diferenças entre os homens e as mulheres, a fim de apontar elementos que representam essas duas categorias e que justifiquem as ideias misóginas e patriarcais de que homens são superiores as mulheres. Essa busca pela diferença acaba por criar regras préestabelecidas sobre o que é ser homem ou ser mulher e ainda alimenta um sistema social baseado na segregação e no preconceito, não só de gênero, uma vez que essa é apenas uma das vertentes dessa questão. Além disso, toda essa construção sobre o que é devido a cada papel, vai variar de cada cultura e por essa razão, não há uma definição universal sobre isso.

Ainda sobre desigualdade, "Quando alguém afirma que um garoto "corre que nem menina" está usando essa expressão de forma negativa, de modo a desqualificá-lo. [...] "ela trabalha duro que nem homem" é usado de forma positiva e valoriza o trabalho de uma mulher: usa-se o estereótipo de que todo homem é trabalhador" (Ibid., 2016, p. 
17). Essa desvalorização teve início ainda na revolução industrial, quando os homens que ocupavam os cargos da educação e passaram a trabalhar nas fabricas, delegando assim seus postos às mulheres, uma vez que essas ocupavam o lugar de cuidadoras. Isso se estende até os dias de hoje em que certos trabalhos são classificados com masculinos e outros como femininos, reflexo desses estereótipos criados lá atrás.

O comportamento esperado na escola também é marcado por expectativas de gênero. Quando pensamos que "matemática é coisa de menino", que "menina é mais caprichosa", enfim, que certas coisas são próprias de meninas e outras de meninos, estamos limitando as aprendizagens e as experiências de vida das crianças ou adolescentes (Ibid., 2016, p. 19).

No espaço da escola, esses papéis, regras, estereótipos continuam a se reproduzir, nas aulas e atividades de dança, teatro, esportes, por exemplo. Elas são justificadas através da explicação atividades para "meninos" e "meninas" como regras sociais, com códigos e significados que indicam quem pertence ao grupo feminino e quem pertencem ao grupo masculino e desempenham as funções sociais previamente determinadas e culturalmente impostas e esperadas.

Aquilo que compreendemos como preconceito é dinâmico, uma vez que envolve relações de poder em diversas instâncias, como já foi dito, sendo elas as sociais, políticas, econômicas, culturais, simbólicas e até as conceituais como, de raça, etnia, cor, classe e ou gênero. Todas essas relações sociais que podem ter como resultado certos preconceitos, são antes de tudo, a falta de respeito pelas múltiplas manifestações e diversidades que encontramos na sociedade.

Entendo essa dinâmica de relações de gênero e dessas separações entre meninos e meninas e que até hoje se manifesta dentro das instituições escolares e em outras situações sociais, refletem na desigualdade e na disseminação de preconceitos de gênero. Além disso, naturaliza a opressão e estigmas que marcam a sociedade e determina e por vezes justifica comportamentos segregadores e machistas.

Por essa razão, a escola sendo um dos agentes de desenvolvimento e importante para o processo de educação do indivíduo, representa uma parcela importante no trabalho de formar o pensamento crítico e o cidadão consciente. Por isso, cabe também 
a instituição escolar, repousar sobre essas questões que a muito vem interferindo socialmente e que cria desigualdade e reforça preconceitos.

Ainda que seja formado de pessoas que por força da naturalização dessas relações baseadas na diferença biológica de gênero, naturalizaram comportamentos de divisão e reproduzem isso na escola, a dinâmica do estudo de caso se faz cada vez mais importante nos dias de hoje, uma vez que fomentam a discussão do assunto e traz a luz o problema da desigualdade para dentro da escola. Só a partir de discussões e de debates é possível alcançar resultados e diminuir cada vez mais essas ideias reforçadoras do comportamento preconceituoso e ultrapassado de que existe uma superioridade ou uma separação por gênero.

As pessoas são livres para realizar as atividades que tem vontade e são capazes de se destacar nelas e não é o gênero, a classe, ou qualquer outra razão que determina a qualidade do que ela faz. Um menino pode ser um excelente cuidador, assim como uma menina pode se destacar no futebol. Por essa razão, cabe a escola estimular da mesma maneira todos os indivíduos que escolham desempenhar qualquer tipo de atividade educativa.

\section{METODOLOGIA DE PESQUISA}

A pesquisa foi iniciada a partir do grande interesse despertado sobre a sexualidade nos espaços escolares, a partir de então iniciei uma busca incessante por materiais que contemplem o tema e leituras que agreguem na construção do presente trabalho. Para a escolha do tema foram observadas questões como a sua relevância para a sociedade atual, para a área da educação além de outras questões já levantadas aqui. Silva e Menezes (2005, p. 30) ao falar sobre pesquisas ressaltam que: “[...] deverá levar em conta, para a escolha do tema, sua atualidade e relevância, seu conhecimento a respeito, sua preferência e sua opinião para lidar com o tema escolhido.".

Considerando a relevância do tema para a atualidade e o interesse da busca de maiores conhecimentos sobre o mesmo, foi realizada uma pesquisa visando trazer maiores informações sobre objeto de estudo, sobre o tema apresentado. Realiza-se o levantamento bibliográfico sobre o tema e, ao final da pesquisa, acrescenta-se considerações a fim de colaborar com as pesquisas sobre o assunto em questão.

O presente trabalho apresenta natureza básica, visto que visa trazer análises dos 
dados aqui apresentados e contribuições para a área que a temática abrange. Silva e Menezes (2005, p. 20) descrevem como básica a pesquisa que "objetiva gerar conhecimentos novos úteis para o avanço da ciência sem aplicação prática prevista. Envolve verdades e interesses universais".

A pesquisa pode ser caracterizada como qualitativa e não objetiva enumerar ou medir eventos, através desta, visa-se obter dados descritivos, de forma a significar os fatos, que são essenciais para a compreensão e explicação das questões elucidadas neste trabalho, sendo, ao final deste trabalho, apresentados resultados em forma de conceitos e ideias que foram adquiridos e desenvolvidos ao longo desta pesquisa. Silva e Menezes (2001, p. 20) definem a pesquisa qualitativa com o seguinte trecho:

Considera que há uma relação dinâmica entre o mundo real e o sujeito, isto é, um vínculo indissociável entre o mundo objetivo e a subjetividade do sujeito que não pode ser traduzido em números. A interpretação dos fenômenos e a atribuição de significados são básicas no processo de pesquisa qualitativa. Não requer o uso de métodos e técnicas estatísticas. $\mathrm{O}$ ambiente natural é a fonte direta para coleta de dados e o pesquisador é o instrumento-chave.

A pesquisa aqui desenvolvida foi realizada através de uma Pesquisa Bibliográfica na qual foram reunidas e analisadas informações e dados sobre a sexualidade nos espaços escolares fazendo uma abordagem crítica do atual cenário educacional através de estudos já publicados. Gil (1991) compreende a Pesquisa Bibliográfica como aquela que foi "elaborada a partir de material já publicado, tais como livros, artigos de periódicos e materiais disponibilizados na internet".

Os autores principais que serviram como base referencial e que contribuíram para a realização desta pesquisa foram: Aran (2006), Bordini (2009), Lins(2016), Louro (1997), Mello (2004),Meyer(2013), além dos documentos oficiais do MEC e as Leis.Tais teóricos foram escolhidos para fundamentar esta pesquisa por apresentarem ideias e considerações tidas como relevantes para a área educacional- pedagógica e, principalmente, alguns desses teóricos apresentam ideias e questões importantes a respeito do assunto tratado neste trabalho. 


\section{RESULTADOS E DISCUSSÃO}

A sexualidade faz parte da vida de todos, sendo universal e ainda assim, singular. Ela se constitui de aspectos individuais, sociais, culturas e psíquicos. Ainda que seja natural e comum a todos, ainda é tabu tanto no âmbito da escola, quando dentro da casa dos alunos. $\mathrm{O}$ assunto ainda é polêmico porque envolve uma série de preconceitos e estereótipos, no entanto sua discussão se faz necessária uma vez que a escola é o local que deve acolher a multiplicidade de seres e suas singularidades. Nesse sentido, preciso estar aberta a um diálogo democrático e sem julgamentos.

A discussão da sexualidade no âmbito educacional tem o objetivo de promover a educação integral da criança e do adolescente, como lhes é de direito, nesse sentido, discutir a sexualidade tem a função de promover a Educação Sexual.

A educação sexual se iniciou nas escolas no começo do século XX com objetivo de controle epidemiológico. Os discursos eram repressivos e baseados na moral religiosa, o que reforçava o caráter higiênico das estratégias de saúde pública vigentes na época. A discussão política sobre os direitos sexuais a partir do movimento feminista ampliou as discussões sobre sexualidade e passou-se a discutir a questão para além do seu caráter biológico o que tornou possível que ela fosse compreendida como prática aliada à saúde física e mental (FURLANETTO et al., 2018).

Segundo Moizes e Bueno (2010), a ausência da Educação Sexual transcende a forma tradicional de ensino que está restrita a visão biológica e médica, e que é uma das principais razões para a falta de adesão dos adolescentes ao sexo seguro.

Os Parâmetros Curriculares Nacionais (PCNS) dispõem que sexualidade seja apresentada a partir da transversalidade dos conteúdos, ou seja, a partir de todas as áreas do conhecimento dentro da escola. Uma vez discutidos, os assuntos devem voltar, com conteúdo mais aprofundado, todas as vezes que houver interesse, por parte dos alunos. Moizes e Bueno (2010) apontam como sendo um dos maiores problema de colocar o professor como agente de execução dos objetivos propostos pelos PCNS no que se trata em cumprir com o objetivo da transversalidade, há que se pensar na sua real condição de trabalho e na qualidade de sua formação profissional. A transversalidade desse tema quer dizer que o professor, precisa não só oferecer os conteúdos da sua matéria dentro do currículo e também de outras mais especificas dos 
quais nem sempre está habituado a lidar. O maior desafio é capacitar esses professores para desenvolver que eles possam desenvolver trabalhos de maneira eficaz e que possam esclarecer questões a respeito da sexualidade em sala de aula.

Porém é preciso entender que o professor não precisa ser especialista na área da sexualidade, ele precisa apenas ser informado e capacitado o suficiente para conseguir fomentar discussões e pensamento crítico sobre o tema, tornando-se assim mediador do conhecimento. A escola funciona com a educação preventiva.

Furlanetto (2018) chama a atenção para as condutas discriminatórias de alguns professores e profissionais da educação, em relação às manifestações sexuais dos alunos, o que segundo ele marca a falta de capacitação para lidar com assuntos relacionados à sexualidade e reforça a propagação de propostas pedagógicas amparadas em concepções religiosas, higienistas e heteronormativas.

\section{CONSIDERAÇÕES FINAIS}

A orientação sexual na escola deve ser entendida como uma atividade transversal, ou seja, atravessar todas as disciplinas ou atividades escolares, uma vez que é inerente ao ser humano, construída coletiva e socialmente ao longo do desenvolvimento dos indivíduos. A escola é espaço que exercesse função social, responsável pelo desenvolvimento intelectual, social e cultural dos seus alunos. Sendo assim, a sexualidade que atravessa a vida dos indivíduos em todas as suas fases do desenvolvimento, deve ser abordada de maneira natural e embasada em conhecimento científico. Porém isso só é possível quando os profissionais têm formação adequada para lidar com a temática.

As diferentes percepções, padrões culturais e sociais e visões de mundo, fazem com que falar sobre sexualidade seja um desafio tanto na escola, quanto fora dela, mas em especial na educação sexual é importante que os professores sejam capacitados para que trabalhem a partir de critérios norteadores que sirvam para diminuir conflitos e visões pessoais que podem ser muitas vezes influenciadas pela moral religiosa ou políticas dos profissionais. Isso não quer dizer que eles precisam ser especialistas sobre o tema, mas que devem receber embasamento teórico suficiente para conhecer o assunto e assim utilizarem deste para mediar em sala de aula.

A sexualidade sempre ocupou um lugar importante nas sociedades. No entanto 
hoje em dia é um centro de debate e discussão, já que as pessoas nem sempre sabem que decisão tomar, e é necessário que os adolescentes possam escolher a maneira de se comportar nessa área. Os jovens e crianças constantemente fazem perguntas e têm dúvidas em relação à sua sexualidade e é necessário que essas preocupações tenham um resultado satisfatório para ambos, e a comunidade em que estão imersos.

Há aqueles que consultam seus amigos ou seus pais, mas pode acontecer que muitas vezes eles não encontram a resposta desejada. Nesta área, desenvolve-se a educação sexual para a geração de adolescentes e crianças brasileiras, que visa abordar as diferentes questões sob uma perspectiva social, psicológica e cultural, já que a sexualidade não inclui apenas aspectos biológicos.

A integralidade dos objetivos do Programa abrange aspectos biológicos, psicológicos, sociais, culturais, afetivos, éticos e legais. Isso permite considerar o ensino de conteúdos escolares vinculados às experiências de crianças e adolescentes. Considerar a educação sexual abrangente implica que a escola institua um espaço sistemático de ensino e aprendizagem que inclua conteúdos de diferentes áreas curriculares, apropriadas às idades das crianças.

Assumir a educação sexual a partir de uma perspectiva integral exige um trabalho voltado à promoção da aprendizagem do ponto de vista cognitivo, mas também no nível emocional e nas práticas específicas relacionadas à vida em sociedade.

Conclui-se então que mesmo sendo um assunto pouco discutido ele se faz importante dentro das escolas uma vez que pode ser usado para prevenir gravidez precoce, prevenção e doenças sexualmente transmissíveis, além de abordar assuntos que dizem respeito à pluralidade e multiplicidade de formas de existir no mundo.

\section{REFERÊNCIAS}

ARÁN, M. A transexualidade e a gramática normativa do sistema sexo-gênero. Ágora, Rio de Janeiro,2006.

BEAUVOIR, S. de. O segundo sexo: a experiência vivida. 2a ed. São Paulo, SP: Difusão Europeia do Livro, 1967.

BORDINI, S. Discursos sobre sexualidade nas escolas municipais de Curitiba. Dissertação (Mestrado) - UFP, Curitiba, 2009. 
BRASIL. Constituição. República Federativa do Brasil. Brasília: Senado Federal. Centro Gráfico, 1988. BRASIL. Política Nacional de Educação Infantil. Brasília: MEC/SEF, Coordenação de Educação Infantil, 1994. BRASIL. Lei de Diretrizes e Bases da Educação Nacional - Lei no 9.394/96. Brasília: MEC, 1996

CONFERÊNCIA NACIONAL DE EDUCAÇÃO (CONAE), 2010, Brasília, DF. Construindo o Sistema Nacional articulado de Educação: o Plano Nacional de Educação, diretrizes e estratégias; Documento Final. Brasília, DF: MEC, 2010b FIGUEIRÓ, M. N. D. Educação Sexual: retomando uma proposta, um desafio. 2. ed. Londrina: Ed. da UEL, 2001

FREIRE, Paulo. Pedagogia da Autonomia: saberes necessários à prática educativa. São Paulo: Paz e Terra, 1996. (Coleção Leitura).

FURLANETTO, Milene Fontana et al . Educação sexual em escolas brasileiras: revisão sistemática da literatura. Cad. Pesqui., São Paulo, v. 48, n. 168, p. 550571 , jun. 2018 . Disponível em <http://www.scielo.br/scielo. Php?Script=sci_arttext\&pid=S0100-15742018000200550\&Ing=pt\&nrm=iso >. Acesso em 16 jun. 2020.

LINS, Beatriz Accioly; MACHADO, Bernardo Fonseca; ESCOURA, Michele. Entre o azul e o cor-de-rosa: normas de gênero. In. (Orgs.). Diferentes, não desiguais: a questão de gênero na escola. São Paulo: Editora Reviravolta, 2016.

LOURO, G. L. Gênero, sexualidade e educação: Uma perspectiva pós estruturalista. 6ạ ed. Petrópolis, RJ: Vozes. 1997.

MELLO, Guiomar Nano de. Educação e Sentimento. É preciso discutir essa relação. In: Revista Nova Escola, Outubro/2004.

MEYER, D. E. Gênero e educação: teoria e política. In: LOURO, G. L.; FELIPE, J.; GOELLNER, S. V. (orgs.). Corpo, gênero e Sexualidade: Um debate contemporâneo na educação. 9ạ ed. Petrópolis, RJ: Vozes, 2013.

MOIZES, Julieta Seixas; BUENO, Sonia Maria Villela. Compreensão sobre sexualidade e sexo nas escolas segundo professores do ensino fundamental. Rev. esc. enferm. USP, São Paulo, v. 44, n. 1, p. 205-212, Mar. 2010. Available from $<$ http://www.scielo.br/scielo.php?script=sci_arttext\&pid=S0080623420100001 00029\&lng=en\&nrm=iso>. Acesso em 15 June 2020.

NARVAZ, M. G.; KOLLER, S. H. metodologias feministas e estudos de gênero: articulando pesquisa, clínica e política. Psicologia em Estudo, Maringá, PR, v. 11, n. 3, p. 647654, set./dez. 2006.

SILVA, M. da. O hábito professoral: o objeto dos estudos sobre o ato de ensinar na sala de aula. Revista Brasileira de Educação. Rio de Janeiro, n.29, maio/ago. 2005. 
SOUZA, Lúcia Aulete Búrigo; GRAUPE, Mareli Eliane. Gênero e Políticas Públicas na Educação. In. Anais do III Simpósio Gênero e Políticas Públicas, Universidade Estadual de Londrina, 27 e 29 de maio de 2014. 


\title{
CAPÍTULO VII
}

\section{A PERCEPÇÃO DE GÊNERO POR ADOLECENTES: VIVÊNCIAS EM UMA ESCOLA PÚBLICA DO OESTE POTIGUAR}

\author{
Mayame Jordânia Rebouças de Oliveira ${ }^{1}$ \\ Wesley Queiroz Peixoto ${ }^{2}$ \\ Julyana Rodrigues Maciel ${ }^{3}$ \\ Ana Júlia Queiroz Silva ${ }^{4}$ \\ Samira Suiany Fernandes de Oliveira ${ }^{5}$ \\ Bruna Raquel Garcia de Souza ${ }^{6}$
}

\footnotetext{
${ }^{1}$ Graduada do curso de Enfermagem. Universidade Potiguar - UnP

2 Pós-graduando em Saúde Materno-Infantil. Programa de Residência Multiprofissional em Saúde Materno-Infantil UFRN

${ }^{3}$ Pós-graduanda em Enfermagem em Pediatria e Neonatologia. Faculdade Venda Nova do Imigrante - FAVENI

4 Graduada do curso de Enfermagem. Universidade Potiguar - UnP

5 Pós-graduanda em Enfermagem em Urgência, Emergência e Trauma. Universidade Potiguar - UnP

6 Graduada em Enfermagem. Universidade Potiguar - UnP
}

\section{RESUMO}

O estudo em questão tem como objetivo relatar a experiência de acadêmicos da última série do curso de enfermagem ao desenvolverem ação sobre gênero com adolescentes de uma escola pública do Rio Grande do Norte. Como metodologia, utilizou-se a revisão bibliográfica a fim de dar sustentação teórica aos apontamentos realizados, e a observação participante como método analítico. A atividade foi desenvolvida com turmas do nono ano do ensino fundamental, tendo a participação de 35 adolescentes, aproximadamente. Ao iniciar o debate percebeu-se que o público alvo detinha conhecimento acerca do assunto, principalmente acerca de questões que envolvem relações afetivas e sexuais/reprodutivas. A partir das discussões, os acadêmicos puderam dar significado à alguns apontamentos realizados pelos adolescentes, muitos vítimas de violência de gênero, mas sem entendimento teórico, até então, desse termo. Através da realização desta ação, afirma-se que as vivências de gênero mantêm-se viva no ambiente escolar, entretanto apresenta-se por meio do machismo, da homofobia, da heteronormatividade, fazendo-se necessária a criação de um espaço de diálogo a fim de ampliar o conceito e discussões sobre a temática, contribuindo diretamente para a qualidade de vida dos adolescentes bem como das suas relações sociais.

Palavras-chave: Gênero. Saúde do adolescente. Educação em Saúde.

\section{INTRODUÇÃO}

Embora não tenha sido criado pelo feminismo, foi através das feministas anglosaxãs que o termo "gênero" passou a ser distinto do termo "sexo", com o objetivo de 
rejeitar o pensamento restrito apenas à forma biológica existente até então, passando a ser pensado também como instrumento de análise para identificar e denunciar as diferenças presentes nas relações entre homens e mulheres em nossa sociedade (COLLING, 2018).

As temáticas relacionadas à gênero e sexualidade têm sido alvo de debates em diferentes perspectivas, abordagens de pensamento e concepções, evidenciando a importância de estudos sobre elas e de como as políticas educacionais têm tratado esses temas (COSTA; SILVA, 2019). Discussões sobre Educação Sexual se tornaram mais intensas no Brasil após o período de redemocratização que se seguiu ao fim da ditadura iniciada em 1964 e intensificada com o Al-5, em 1968. Questões sobre cidadania e direitos passaram a fazer parte dos discursos sociais e políticos a partir da Constituição de 1988, e em seu eixo os marcadores de Gênero e Sexualidade ocuparam lugar de destaque. Debates se tratando de minorias, mulheres, homossexuais atrelados aos direitos humanos, em um primeiro momento, travados nas arenas identitárias, direcionaram-se, posteriormente, para uma arena política (MONTEIRO; RIBEIRO, 2020).

Nos últimos anos tem aumentado consideravelmente a visibilidade de temas relacionados à diversidade sexual e de gênero nos meios de comunicação (novelas, noticiários, filmes e redes sociais), bem como a luta por direitos da população LGBTQI+. A valorização da diversidade sexual e de gênero se opõe à ênfase nas convenções de gênero e nos padrões de heteronormatividade, caracterizada pelo caráter imposto da heterossexualidade, articulado ao estabelecimento de uma ordem social na qual o homem deve seguir as convenções sociais de masculinidade e as mulheres de feminilidade (SOARES; MONTEIRO, 2019).

Para o enfrentamento de questões relativas às dificuldades de se debater temas como gênero e sexualidade na escola, os estudos que abordam tais temáticas preconizam a formação de professores como estratégia fundamental na contribuição ao enfrentamento dessas problemáticas e na construção de processos educativos inclusivos. Assim, existem muitos autores que abordam a importância da formação de professores para a superação das discriminações de gênero na escola (OLTRAMARI; GESSER, 2019). 
Considerando o exposto, este estudo tem como objetivo relatar a experiência de acadêmicos da última série do curso de enfermagem ao desenvolverem ação sobre gênero com adolescentes de uma escola pública do Rio Grande do Norte.

\section{METODOLOGIA}

O estudo que discorre trata-se de uma pesquisa qualitativa, na modalidade de relato de experiência, que usou a revisão de literatura como metodologia para dar sustentação teórica aos apontamentos realizados, bem como a observação participante como método de análise de dados.

A revisão de literatura baseia-se no uso de estudos previamente publicados em periódicos, livros, manuais, sendo um método que permite a elaboração de pesquisas inteiramente com dados de outros estudos, bem como possibilitam dar base teórica para a contestação de informações de uma pesquisa (BRIZOLA; FANTIN, 2016).

O método da observação participante permite ao pesquisador a construção de uma narrativa de ordem qualitativa acerca de ações tema de uma pesquisa, sendo este tipo de método analítico, geralmente, empregado para relatar experiências, como neste estudo (MÓNICO et al. 2017).

A atividade discutida neste estudo foi desenvolvida no segundo semestre de 2019 em escola da rede estadual de ensino do Rio Grande do Norte, tendo como público participante discentes de duas turmas de nono ano do ensino fundamental, contando com, aproximadamente, 35 adolescentes. A realização da ação se deu como proposta da disciplina de Estágio Supervisionado Obrigatório II, sendo efetivada dentro do Programa Saúde na Escola.

A escolha da temática se deu a partir de solicitações das próprias turmas, que tiveram a oportunidade de sugerir temas para discussão por meio de uma "caixa de sugestões" deixada em um ambiente da escola, onde os alunos que tiveram interesse puderam deixar sugestões anonimamente.

A ação durou cerca de duas horas e foi desenvolvida em uma sala de aula da referida instituição de ensino, onde tanto os adolescentes quanto os graduandos foram dispostos sentados, em círculo, a fim de permitir a horizontalidade do debate. 


\section{RESULTADOS E DISCUSSÕES}

O interesse por parte dos adolescentes em discutir condições de gênero expressam a demanda deste público pelo entendimento das vertentes que partem desta temática. Apesar disso, perspectivas ideológicas negam veementemente a necessidade de debates acerca das inúmeras variantes de gênero, criando um estigma negativo quanto a estas discussões que refletem diretamente sobre a saúde e qualidade de vida dos indivíduos (REIS; EGGERT, 2017; BORGES; BORGES, 2018).

A atividade relatada neste estudo foi idealizada visando, inicialmente, compreender as tendências de debates acerca da temática de gênero, ou seja, visou-se entender sobre quais abordagens de gênero os adolescentes gostariam de discutir, considerando a extensão do tema em questão.

As discussões sobre a temática de gênero com adolescentes são muito importantes considerando as influências dos gêneros, nos seus mais diversos aspectos, sobre a saúde dos indivíduos. O debate com este público permite a reflexão destes acerca das condições sociais nas quais estão envolvidos, contribuindo para a construção de apontamentos críticos acerca das desigualdades de gênero (PIRES, 2018).

Deste modo, a primeira ação da atividade foi questionar aos discentes qual a compreensão destes acerca da temática de gênero. A partir desta indagação surgiram concepções sobre a definição da temática, onde as principais associações referiram-se a orientação sexual, identidade de gênero e sexo biológico.

Com base nisto os acadêmicos puderam perceber que o entendimento dos adolescentes quanto à temática de gênero é voltada principalmente para questões que envolvem relações afetivas e sexuais/reprodutivas, não pautada, inicialmente, em discussões referentes a violência de gênero, aos movimentos feministas, movimento negro, entre outros (FERNANDES, 2016; BALBINOTTI, 2018).

A partir dessa análise de conhecimento, a discussão iniciou-se pautada da definição de orientação sexual e identidade de gênero, e o grau de importância do sexo biológico em cada um desses. Esse momento rendeu discussões acaloradas entre os adolescentes, manifestações de expressões distintas de vivências pessoais enquanto heterossexuais, bissexuais, e o impacto disso sobre a vida de cada um. Apesar de jovens, muitos já se definiam héteros, assim como alguns outros como bissexuais. 
Atentando para os diálogos, a ligação indireta realizada pelos adolescentes entre suas manifestações de orientação sexual e a qualidade de vida de cada um, principalmente para os não heterossexuais, evidencia a necessidade por discussões dessa natureza com este público (REIS; EGGERT, 2017), buscando compreender a realidade social de cada indivíduo bem como suas necessidades de saúde.

As falas quanto as vulnerabilidades sociais voltadas para o campo da orientação sexual e identidade de gênero possibilitaram introduzir na discussão a violência de gênero, ou melhor, permitiram definir que muitas das perspectivas abordadas, bem como vivências de alguns dos adolescentes, caracterizam-se como violência de gênero.

Poucos adolescentes sabiam o significado da expressão violência de gênero, entretanto a vivência prática desta violência era realidade de muitos, principalmente das mulheres e dos indivíduos não héteros. A literatura confirma a maior prevalência da violência gênero em determinados grupos, principalmente de mulheres, negros e da população LGBTQIA+ (FERNANDES, 2016; BALBINOTTI, 2018; GARCIA, 2019).

A atividade foi finalizada com uma abordagem reflexiva sobre as discussões que haviam se dado durante a vivência, manifestada por alguns dos adolescentes de modo a referir-se a necessidade de respeito por parte do todos quanto as expressões e necessidades individuais de cada um, independentemente do sexo, identidade de gênero e orientação sexual.

\section{CONSIDERAÇÕES FINAIS}

Os apontamentos realizados neste estudo permitem afirmar que as discussões sobre gênero são necessárias no ambiente escolar. Esta afirmação pode ser reforçada considerando os relatos de violência de gênero sofrida por uma parcela do público alvo da ação, fato que expõe a indispensabilidade de debates sobre tal tema dentro do espaço escolar.

Os adolescentes têm conhecimento acerca de condições de gênero, entretanto o não acesso à informação os coloca como reprodutores de culturas machistas, homofóbicas, sexistas. A atuação de atividades educativas, como visto, permite delinear o acontecimento dessas ações opressoras permitindo que os adolescentes realizem críticas as próprias práticas. 
Vale salientar, ainda, que a efetivação do Programa Saúde na Escola (PSE) surge como uma alternativa viável para a implementação de atividades com temáticas voltadas para o campo social, considerando a inevitável interferência deste setor sobre a saúde e qualidade de vida de qualquer população.

Este estudo abre margem para ensaios mais aprofundados sobre a temática de gênero, principalmente relacionando a importância deste tema à uma construção social pautada na desconstrução do machismo e patriarcado, principais responsáveis pela violência de gênero à grupos não hetéronormativos.

\section{REFERÊNCIAS}

BALBINOTTI, Izabele. A violência contra a mulher como expressão do patriarcado e do machismo. Revista da ESMESC, [s.l.], v.25, n. 31, p. 239-264, 2018. Disponível em: https://revista.esmesc.org.br/re/article/viewFile/191/165. Acesso em: 22 ago. 2020.

BORGES, Rafaela Oliveira; BORGES, Zulmira Newlands. Pânico moral e ideologia de gênero articulados na supressão de diretrizes sobre questões e gênero e sexualidade nas escolas. Revista Brasileira de Educação, [s.I.], v. 23, p. 01-23, 2018. Disponível em: https://www.scielo.br/pdf/rbedu/v23/1809-449X-rbedu23-e230039.pdf. Acesso em: 22 ago. 2020.

BRIZOLA, Jairo; FANTIN, Nádia. Revisão da literatura e revisão sistemática da literatura. Revista de Educação do Vale dos Arinos, Juara, v. 3, n. 2, p. 23-39, 2016. https://periodicos.unemat.br/index.php/relva/article/view/1738/1630. Acesso em: 20 ago. 2020.

COLLING, Leandro. Gênero e sexualidade na atualidade. Salvador: UFBA, Instituto de Humanidades, Artes e Ciências; Superintendência de Educação A Distância, 2018. 69

p. Disponível em: https://educapes.capes.gov.br/bitstream/capes/430946/2/eBook_\%20Genero_ e_Sexualidade_na_Atualidade_UFBA.pdf. Acesso em: 03 set. 2020.

COSTA, Regina Rodrigues; SILVA, Aida Monteiro. Abordagens de gênero e sexualidade: um contraponto ao escola sem partido. Retratos da Escola, [S.L.], v. 13, n. 26, p. 499-512, 14 nov. 2019. Confederacao Nacional dos Trabalhadores em Educacao (CNTE). http://dx.doi.org/10.22420/rde.v13i26.936. Disponível em: http://retratosdaescola.emnuvens.com.br/rde. Acesso em: 30 ago. 2020.

FERNANDES, Danubia de Andrade. O gênero negro: apontamentos sobre gênero, feminismo e negritude. Estudos feministas, Florianópolis, v. 3, n. 24, p. 691-713, 2016. Disponível em: https://www.scielo.br/pdf/ref/v24n3/1806-9584-ref-2403-00691.pdf. Acesso em: 22 ago. 2020. 
GARCIA, Tamires de Oliveira. Política criminal e violência contra a população LGBT: um estudo com a polícia civil e movimentos sociais em Porto Alegre. Canoas, RS: editora Unilasalle, 2019.

PIRES, Marisa Barreto. Provocações sobre questões de gênero com adolescentes. Revista Diversidade e Educação, [s.I.], v. 6, n. 2, p. 202-206, 2018. Disponível em: https://periodicos.furg.br/divedu/article/view/8531/5689. Acesso em: 20 ago. 2020.

MÓNICO, Lisete S. et al. A Observação Participante enquanto metodologia de investigação qualitativa. In: Congresso Ibero-Americano Em Investigação Qualitativa, 6., 2017, Salamanca. Proceedings.... Salamanca: Atas, 2017. v. 3, p. 724 - $733 . \quad$ Disponível em: <https://proceedings.ciaiq.org/index.php/ciaiq2017/article/view/1447/1404>. Acesso em: 24 abr. 2019.

MONTEIRO, Solange Aparecida de Souza; RIBEIRO, Paulo Rennes Marçal. Sexualidade e Gênero na atual BNCC: possibilidades e limites. Pesquisa e Ensino, [S.L.], v. 1, p. 1-24, 1 maio 2020. Pesquisa e Ensino. http://dx.doi.org/10.37853/pqe.e202011. Disponível em: https://revistas.ufob.edu.br/index.php/pqe/article/view/626/907. Acesso em: 30 ago. 2020.

OLTRAMARI, Leandro Castro; GESSER, Marivete. Educação e gênero: histórias de estudantes do curso gênero e diversidade na escola. Revista Estudos Feministas, [S.L.], v. 27, n. 3, p. 1-14, 2019. FapUNIFESP (SciELO). http://dx.doi.org/10.1590/1806-9584-2019v27n357772. Disponível em: https://www.scielo.br/pdf/ref/v27n3/1806-9584-ref-27-03-e57772.pdf. Acesso em: 28 ago. 2020.

REIS, Toni; EGGERT, Edla. Ideologia de gênero: uma falácia construída sobre os planos de educação brasileiros. Educação \& Sociedade, Campinas, v. 38, n. 138, p. 9-26, 2017. Disponível em: https://www.scielo.br/pdf/es/v38n138/1678-4626-es-38138-00009.pdf. Acesso em: 22 ago. 2020.

SOARES, Zilene Pereira; MONTEIRO, Simone Souza. Formação de professores/as em gênero e sexualidade: possibilidades e desafios. Educar em Revista, [S.L.], v. 35, n. 73 , p. 287-305, fev. 2019. FapUNIFESP (SciELO). http://dx.doi.org/10.1590/0104-4060.61432. Disponível em: https://www.scielo.br/pdf/er/v35n73/0104-4060-er-35-73-287.pdf. Acesso em: 27 ago. 2020. 


\title{
CAPÍTULO XIII
}

\section{REPRESENTATIVIDADE FEMININA NO CENÁRIO ACADÊMICO: ESTUDO SOBRE A PARTICIPAÇÃO DAS MULHERES EGRESSAS DO CURSO DE COMUNICAÇÃO SOCIAL DA UFCG}

\author{
Leonardo Pereira Tavares ${ }^{1}$ \\ Marina Magalhães ${ }^{2}$ \\ Assis Souza de Moura ${ }^{3}$
}

\begin{abstract}
${ }^{1}$ Graduando do curso de Comunicação Social com linha de formação em Educomunicação - UFCG
2 Professora do curso de Comunicação Social com linha de formação em Educomunicação - UFCG

${ }^{3}$ Professor do curso de Comunicação Social com linha de formação em Educomunicação - UFCG
\end{abstract}

\section{RESUMO}

A presença das mulheres na ciência e tecnologia é um debate a ser explanado, principalmente em países em desenvolvimento como o Brasil, onde a representatividade feminina nos altos cargos na área científica é mínima, sendo algo decorrente do machismo estrutural que ainda permanece enraizado na sociedade. Este texto busca analisar mulheres egressas do curso de Comunicação Social da Universidade Federal de Campina Grande, e objetiva observar quantas mulheres conseguiram ingressar em mestrado após a formação no referido curso. Para trabalhar este objeto, foi necessário obter uma relação de todos os seus alunos graduados e desenvolver uma análise curricular de todos os discentes que terminaram o curso. Outro ponto abordado foi a representatividade do corpo docente como incentivo a essas mulheres que desejam seguir a carreira acadêmica. Metodologicamente, a pesquisa partiu da comparação entre a lista de alunas formadas fornecida pelo curso em questão e a análise dos seus currículos. Neste contexto, percebemos a importância de criar movimentos e pesquisas que fortaleçam essa luta para que mulheres e homens possam ocupar os mesmos cargos e ter as mesmas oportunidades.

Palavras-chave: Mulheres. Gênero. Ciência. Representatividade. Universidade.

\section{INTRODUÇÃO}

Por muitos anos a presença das mulheres em determinadas áreas foi reprimida, afetando diretamente sua representatividade. Embora seja uma problemática enfrentada com séculos de lutas, há quem ouse ainda ditar o seu lugar e espaço de atuação, principalmente no âmbito profissional. No Brasil, de acordo com Silva (2012), com base em dados fornecidos pelo Conselho Nacional de Desenvolvimento Científico 
e Tecnológico (CNPq), a maior representatividade feminina na academia, com porcentagem acima de 70\%, destaca-se nas áreas de Psicologia, Nutrição, Fonoaudiologia, Economia Doméstica, Linguística e Enfermagem. Porém, nas ditas "ciências duras" as mulheres são minoria, entre elas Geociência, Matemática, Engenharias, Ciência da Computação, Economia e, principalmente, Física, em que a participação feminina é menor que $20 \%$.

Nessa perspectiva, sentiu-se a necessidade de observar como tal representatividade se aplica ao curso de Comunicação Social, com linha de formação em Educomunicação, na Universidade Federal de Campina Grande. Percebe-se que "a ideia de representação está ligada à busca de formas apropriadas de tornar o "real" presente de aprendê-lo o mais fielmente possível por meio de sistemas de significação" e mostrando-se fundamental para o desenvolvimento social e cientifico (SILVA, 2000, p.79).

O presente trabalho aborda uma análise histórica e social das mulheres, a fim de colaborar com o desenvolvimento da pesquisa brasileira com mulheres na contemporaneidade, investigando a relação de gênero com o curso de Comunicação Social da Universidade Federal de Campina Grande (UFCG). Nesse sentido, busca compreender a situação das mulheres egressas nesse curso desde a sua criação em 2009 (LEÃO et al., 2017), até o segundo semestre de 2019, com intuito de verificar quais destas optaram pela carreira acadêmica no período de uma década considerado na análise. Sendo assim, este artigo busca contribuir com o debate sobre o pluralismo na ciência e na tecnologia a partir da realidade que o curso de Educomunicação da UFCG possa oferecer. $O$ intuito do estudo é levantar questionamentos acerca de gênero no cenário acadêmico, buscando compreender a representatividade de mulheres em mestrado, após finalizarem o curso em questão. Espera-se que essa pesquisa possa servir de estímulo a políticas de incentivo por parte da universidade e coordenação do curso para as alunas que desejam seguir carreira acadêmica.

Logo, no que diz respeito à revisão de literatura, este artigo baseia-se nas contribuições de teóricos renomados na área de comunicação, educação, história e psicologia. Entre eles, as pesquisadoras Fanny Tabak (2002), Gilda Olinto (2011) e Rosilene Montenegro (2017), que desenvolvem pesquisas voltadas para questões de gênero. A partir da evolução histórica da participação das mulheres na sociedade, o 
estudo segue uma contextualização da luta das mulheres contra a repressão histórica, seguindo para a presença feminina no contexto científico brasileiro. Por fim, adentra na história do curso de Comunicação Social da UFCG e na participação das mulheres em programas de mestrado após a conclusão desta graduação.

Empiricamente, a metodologia do estudo parte da análise curricular de alunos egressos no referido curso, a fim de descobrir quantas mulheres ingressaram no mestrado após terminarem a graduação em Comunicação Social na UFCG. O processo metodológico fez uso da abordagem indutiva, levantando dados de todas as mulheres formadas pelo curso em questão através de pesquisas curriculares, refletindo em uma análise qualitativa e quantitativa na discussão dos resultados.

\section{REFERENCIAL TEÓRICO}

Tendo em vista as sucessivas lutas que os movimentos em prol da igualdade de gênero vêm travando, este artigo ampara-se em um referencial teórico que buscou evidenciar pontos-chave desse debate, como a luta contra a repressão, conquistas e desafios das mulheres na ciência brasileira.

\subsection{Luta contra a repressão}

Sabe-se que existe um contexto histórico patriarcal que afirma o lugar da mulher como o de cuidar da casa e dos filhos. Sendo assim, quando se trata do universo feminino, tudo que foge do cuidar termina sendo fora do comum para a sociedade. Embora seja uma realidade histórica, ela ainda se perpetua na sociedade contemporânea.

Uma pesquisa desenvolvida para o jornal $O$ Globo revelou que para cerca de $26 \%$ dos homens entrevistados, "um homem que fica em casa para cuidar dos filhos é menos homem" (O GLOBO, 2019). Logo, teoricamente isso seria um papel exclusivo da mulher. Percebe-se, assim, que ainda existe uma divisão de tarefas sobre o que as mulheres podem fazer ou não, a qual se propaga de geração para geração, com meninas sendo ensinadas, desde cedo, a brincar de casinha, boneca, cuidar e cozinhar (FINCO, 2003).

Diante desse cenário, é necessário que pesquisas sejam desenvolvidas para gerar reflexões sobre essa questão, que há pelo menos dois séculos vem sendo bandeira de luta de movimentos sociais ao redor do globo. Tais mobilizações trazem à tona uma luta 
que não deve ser apenas das mulheres, mas sim de toda a sociedade que almeja a igualdade e o bem-estar social. A História mostra que mulheres se reuniram pelo mundo com diversas formas de movimento, principalmente com o feminismo, e cada conquista dessas mulheres trouxe liberdade e avanço (FRANCHINE, 2017).

O movimento feminista vem lutando por isso desde o fim do século XIX, quando na Inglaterra surgiu uma mobilização liderada pelas sufragistas, mulheres que reivindicaram o direito feminino ao voto (sufrágio), mas também ao divórcio, educação e posse de bens (ABREU, 2002). Nas últimas décadas o feminismo vem se reinventando, desdobrando e atualizando suas questões, mas mantendo a busca pela igualdade entre homens e mulheres. Sendo assim, de um modo geral,

o movimento feminista também proporcionou à sociedade moderna a compreensão que as mulheres não mais poderiam ser um grupo oprimido, sendo vítimas e sofrendo as consequências de pertencer a uma sociedade secularmente repressora, preconceituosa e discriminatória. Seria necessário, assim, recriar a relação com o gênero masculino (SILVA, 2010, p.559).

Ao longo dos séculos, o movimento feminista se manifestou através de diversas fases, conhecidas como "ondas do feminismo". Narvaz e Koller (2006) sugerem uma categorização do feminismo em três ondas, atribuídas a períodos diferentes da história. A primeira onda teria sido caracterizada pelas revoltas do operariado, nas quais as mulheres pediam igualdade e liberdade, principalmente diante da sociedade burguesa que detinha maior poder. Porém, o ponto mais importante desta primeira onda foi o já citado movimento sufragista ocorrido em vários países pelo direito ao voto, iniciado no final do século XIX (MARTINS, 2015).

Após a fase dedicada ao direito político das mulheres, por volta de 1960 uma segunda onda do feminismo voltou-se para a necessidade de incluir novas vivências e histórias. Neste período identificou-se a questão da desigualdade como originada a partir de problemas culturais e políticos. Até então, segundo Fraser (2007), o feminismo partia de um movimento dominado por mulheres brancas e heterossexuais. É sabido também que:

Fomentada pelo radicalismo da Nova Esquerda (New Left), essa onda do feminismo começou como um dos novos movimentos sociais que 
desafiaram as estruturas normatizadoras da socialdemocracia pósSegunda Guerra. Originou-se, em outras palavras, como parte de um esforço maior para transformar o imaginário político economicista que tinha centrado a atenção em problemas de distribuição entre as classes. Nessa primeira fase (novos movimentos sociais) feministas buscaram ampliar o seu imaginário (FRASER, 2007, p.293).

A terceira onda feminista é atribuída à década de 1990, tendo surgido como forma de retificar supostas falhas ocorridas nas ondas anteriores, sobretudo no tocante às diferenças vivenciadas por mulheres advindas de condições sociais e étnicas distintas. Trouxe como proposta a análise das diferenças entre os sexos, com intuito de mover a abordagem de estudos sobre as mulheres e sobre os sexos para a área de estudo das relações de gênero (JESUS, 2014).

A história do feminismo também foi importante para a própria ciência, seja pelo crescimento da participação das mulheres, seja para campos de saber específicos, como os Estudos Culturais. Segundo Stuart Hall,

\footnotetext{
O olhar feminista desafiou os estudos dos meios que até então vinham sendo feitos onde apenas se valorizava programas noticiosos e de caráter político e público, incluindo, então, análises sobre telenovelas e outros gêneros considerados mais 'femininos'. A família foi identificada como um importante espaço de apropriação de produtos culturais, abrindo caminho para investigações inovadoras sobre as conexões entre vida privada e pública. (ESCOSTEGUY, 1998, p.7)
}

As experiências e lutas feministas foram ganhando visibilidade e estudos na área, que partiram de suas vivências e dos movimentos feministas da época. Com isso foi possível notar que "a questão da identidade, problemática fundamental nas reflexões de Stuart Hall, permanece ocupando um lugar central na mesa dos estudos feministas e em sua prática política" (ESCOSTEGUY, 2016, p.74). As conquistas das lutas feministas trouxeram impactos que se perpetuam até a contemporaneidade e reforçam que a presença das mulheres é necessária em todas as áreas de atuação.

\subsection{Mulheres na ciência brasileira}

O incentivo à pesquisa no Brasil é algo que precisa ser trabalhado, sobretudo quando se refere às questões de gênero, em que as dificuldades podem ser ainda maiores. De acordo com Olinto (2011, p.69), existem dois tipos de obstáculos enfrentados pelas mulheres: o primeiro seria a segregação horizontal, em que as 
mulheres são induzidas a escolher destinos trabalhistas diferentes dos homens, inferiorizando-as, acarretando muitas vezes em salários mais baixos; o segundo consiste na segregação vertical, o que seria considerado algo mais invisível, existente entre "os processos que se desenvolvem no ambiente de trabalho que favorecem a ascensão profissional dos homens". Esta é a temática que interessa aos estudos de gênero.

Percebe-se que debates vêm sendo construídos sobre a presença das mulheres ao longo dos anos, não apenas uma área da ciência, mas em diversos campos do conhecimento. Isso ocorre até mesmo nas áreas de estudos que tendem ter uma maior participação de mulheres, como educação, comunicação, saúde e sociologia, voltados para o cuidar e o ensinar (MOREIRA; MATTOS; REIS, 2014).

Entende-se também que:

Uma vez feita a opção pela carreira científica, a mulher se depara com o conflito da maternidade, da atenção e obrigação com a família vis-avis as exigências da vida acadêmica. Algumas sucumbem e optam pela família, outras, pela academia, e um número decide combinar as duas. Sobre essas últimas, não é necessário dizer quanto têm que se desdobrar para dar conta não apenas das tarefas múltiplas, mas também para conviver com consciência duplamente culposa: por não se dedicar mais aos filhos e por não ser tão produtiva quanto se esperaria (ou gostaria). (WOELLNER, 2006, p.15)

Embora sejam inúmeros os desafios das mulheres para ingressarem na vida científica, parte delas sente esse desejo, mas não é motivada a ocupar esses espaços, principalmente quando se fala em pesquisadoras que são mães. Na carreira acadêmica, espera-se que para ser bem-sucedida uma pesquisadora deve manter uma demanda de artigos publicados com uma dedicação total à pesquisa (DA SILVA; RIBEIRO, 2014).

Segundo Silva e Ribeiro (2014, p.460),

reconhecimento na ciência estimula a "corrida" pelo Currículo Lattes, constituindo o campo científico como um espaço de disputas teóricas, rivalidades, cobranças, reproduzindo o sistema cultural que, geralmente, é compartilhado pelos sujeitos que deste campo participam.

Diante do problema apresentado, os programas de mestrado e doutorado devem se adaptar a essas nuanças, criando um sistema que seja mais igualitário, uma vez que "a presença das mulheres na pesquisa e produção científica e tecnológica ainda 
é pequena, e dependendo da área chega a ser insignificante" (MONTENEGRO, GONÇALVES e DA SILVA, 2017, p.2). Este problema da pouca representatividade feminina na ciência e tecnologia se torna ainda mais grave num mundo cada vez mais competitivo.

Para Tabak (2002), a ciência e a tecnologia em um país de terceiro mundo requerem incentivos, juntamente com um conjunto intelectual de toda sua população, para que haja a construção de uma massa crítica que fortaleça a comunidade científica. Isto porque "embora não exista uma discriminação formal ao acesso das mulheres à comunidade científica, a participação das mulheres na produção da Ciência e Tecnologia é limitada", e acaba criando barreiras que resultam na baixa representatividade (TABAK, 2002, p.29).

\subsection{0 curso de comunicação social da UFCG}

O curso de Comunicação Social com linha de formação em Educomunicação da UFCG faz parte do Programa de Reestruturação e Expansão das Universidades Federais (Reuni), com proposta de ingresso de 80 alunos no segundo semestre do ano de 2010 (BRAGA, 2009). Tal projeto pedagógico teve em vista a reestruturação de duas áreas de estudos: Educação e Comunicação.

Embora seja uma área recém construída, a Educomunicação traz para área da Comunicação uma perspectiva que evidencia o ensino/aprendizagem pelos meios de comunicação de massa. Segundo Soares (2011, p. 17), um dos idealistas desse campo de estudo,

a Educomunicação, ao reconhecer e codividir com preocupações, da educação, relacionadas à produção midiática, situa-se a partir de seu lugar específico, que é a interface. Reconhece, em primeiro lugar, o direito universal à expressão, tanto da mídia quanto de seu público. No caso, mais especificamente o direito do público, levando em conta que o sistema vigente desconsidera esta hipótese. Em decorrência, fará todo esforço necessário para ampliar o potencial comunicativo dos membros da comunidade educativa e - no contexto de seu espaço privilegiado, que é a escola - de todos os membros desta comunidade, sejam docentes e discentes, ou, ainda, a comunidade do entorno.

Percebe-se que a Educomunicação é um campo que está sendo estruturado dia após dia. Essa relação entre as duas áreas Educação/Comunicação é de extrema 
importância, pois busca provocar na sociedade um olhar crítico para os meios de comunicação de massa. Vista a importância de um curso de Comunicação Social que oferecesse essa linha de formação, a cidade de Campina Grande passou a oferecer o primeiro bacharelado em Educomunicação ${ }^{1}$ em uma universidade federal no Brasil. Observou-se que não existem pesquisas desenvolvidas sobre a participação feminina nesse campo de estudo, se tornando um dos fatores primordiais para essa coleta de dados.

\section{PROCEDIMENTOS METODOLÓGICOS}

A metodologia deste trabalho baseia-se na coleta de dados, por meio do banco de dados sobre os alunos formados, fazendo uma análise de discentes de turmas diurnas e noturnas, desde a primeira turma até a recém-formada, levando em consideração o ano da pesquisa 2019. O estudo tem o intuito de saber quantas alunas ingressaram em mestrado após terminarem o curso de Comunicação Social da Universidade Federal de Campina Grande.

Quanto à natureza do trabalho, esta pesquisa propõe a realização de uma análise qualitativa e quantitativa dos dados obtidos através da plataforma Lattes do Conselho Nacional de Desenvolvimento Científico e Tecnológico (CNPq) e da lista de egressos fornecidos pela coordenação do referido curso.

O trabalho estrutura-se no método de pesquisa de campo, que consiste em “investigação empírica realizada no local onde ocorre ou ocorreu um fenômeno ou que dispõe de elementos para explicá-lo. Pode incluir entrevistas, aplicação de questionários, testes e observação participante ou não" (VERGARA, 2006, p.45).

A princípio, foi necessário solicitar na coordenação do curso de Comunicação Social a lista com os nomes de todos concluintes a contar da fundação do curso, a qual somava 190 alunos até o dia 4 de novembro, incluindo matriculados nos períodos diurno e noturno. A partir da lista foram enumerados os nomes dos alunos de acordo com o ano em que foram formados, seguindo a ordem alfabética.

\footnotetext{
${ }^{1} \mathrm{O}$ primeiro curso de Licenciatura em Educomunicação foi oferecido pela Universidade de São Paulo USP.
} 
Em seguida, analisou-se o currículo Lattes de cada membro indicado na lista de egressos, classificando-os como mestrandos, mestres ou graduados. Depois de obter tais dados, foi feita uma nova classificação, dessa vez adotando o sexo como critério. Todas as etapas do processo foram feitas manualmente pelos autores e duraram cerca de 30 dias. Como instrumentos de pesquisa, utilizou-se o software Excel para classificar homens e mulheres que concluíram o curso, e os seus respectivos currículos Lattes.

Em seguida buscaremos analisar a representativa das mulheres no corpo docente deste curso, tendo o intuito de saber quantas das professoras são formadas em Comunicação Social. Para isso, foi necessário coletar os dados através do site da instituição e analisá-los através da plataforma Lattes.

\section{APRESENTAÇÃO E ANÁLISE DOS DADOS}

Através da lista disponibilizada pela coordenação do curso, com todas as pessoas que concluíram o curso de Comunicação Social da UFCG, foi possível analisar a quantidade desses alunos através dos anos, incluindo primeiro e segundo semestre como mostra a Tabela 1. Foi possível também analisar os ingressantes de mestrado de acordo com seu ano de formação.

Tabela 1 - Quantidade de egressos de acordo com os anos

\begin{tabular}{|c|c|c|c|c|c|c|}
\hline \multicolumn{7}{|c|}{ NÚMERO DE EGRESSOS (HOMENS E MULHERES POR ANO) } \\
\hline 2013 & 2014 & 2015 & 2016 & 2017 & 2018 & 2019 \\
\hline 4 & 23 & 48 & 37 & 37 & 30 & 11 \\
\hline \multicolumn{7}{|c|}{ INGRESSANTES NO MESTRADO (HOMENS E MULHERES POR ANO) } \\
\hline 0 & 1 & 2 & 0 & 3 & 3 & 1 \\
\hline
\end{tabular}

Fonte: Elaboração própria (2020).

Sendo assim, foi possível perceber que apenas 4 pessoas no ano de 2013.2 conseguiram se formar em três anos e meio (ano de duração do curso), importante ressaltar que dessas 4 pessoas que concluíram no ano de 2013.2 todas são mulheres. Em 2014 as mulheres representaram 20 das 23 pessoas que concluíram o curso. No ano de 2015 se tem o maior número de egressos, composto por 34 mulheres e 14 homens. Já no ano de 2016 cerca de 22 mulheres foram formadas e apenas 15 homens. Em 2017 cerca de 23 mulheres se formaram no curso em questão e apenas 14 homens. No ano 
de 2018 formou-se 17 mulheres e 13 homens. E por fim, em 2019, cerca de 11 pessoas se formaram no curso de comunicação social da UFCG, sendo destas 9 mulheres. Esse número total de concluintes no ano de 2019 corresponde apenas ao primeiro semestre do ano 2019.1.

Quando se analisa os ingressos em mestrado, percebe-se que de acordo com os anos esses números têm aumentado; porém, no ano de 2016 nenhuma das pessoas que concluiu a graduação ingressou no mestrado. No ano de 2017 e 2018 houve os maiores ingressos em mestrado do curso de Comunicação Social. Entre os 9 anos de curso foram formados 190 alunos, destes, 127 são mulheres como pode-se observar no Figura 1.

Figura 1 - Graduados de Comunicação Social

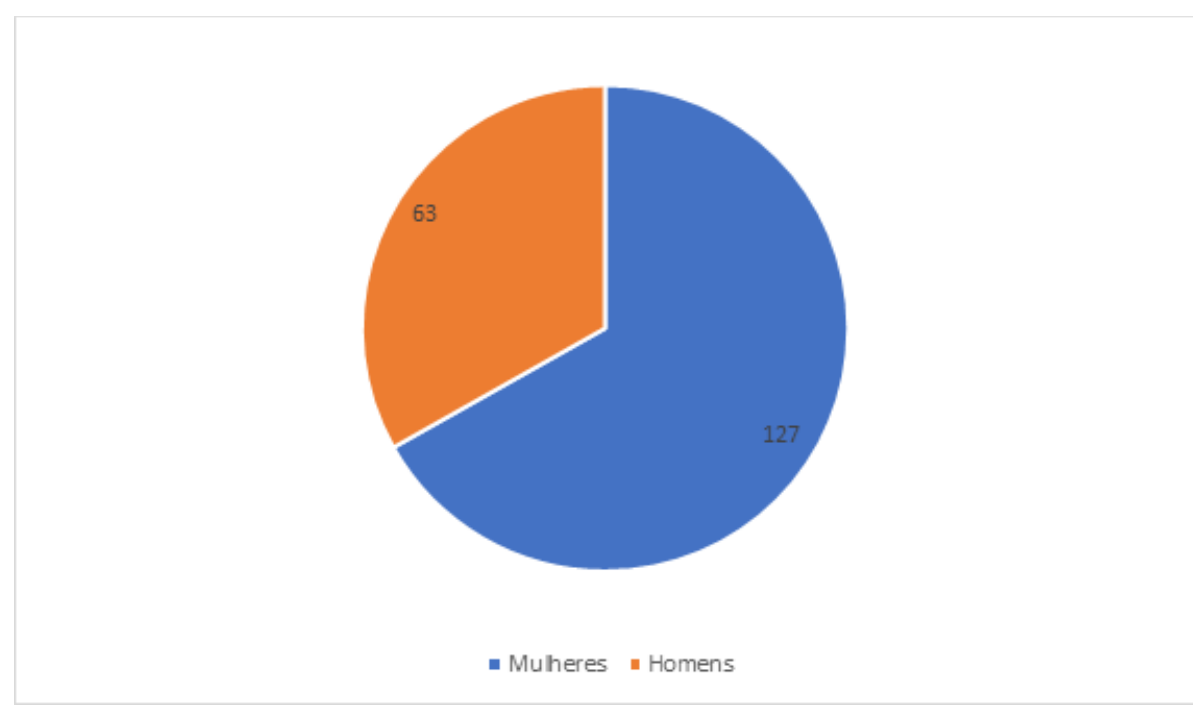

Fonte: Elaboração própria (2020).

As mulheres correspondem ao dobro de formandas em relação aos homens. Tendo em vista esses dados, espera-se que o ingresso de mulheres em mestrado seja maior que o de homens. Entretanto, como mostra a Figura 2, existem 10 ingressos em mestrado, sendo 6 homens e 4 mulheres. 
Figura 2 - Mestrando com graduação em Comunicação Social da UFCG

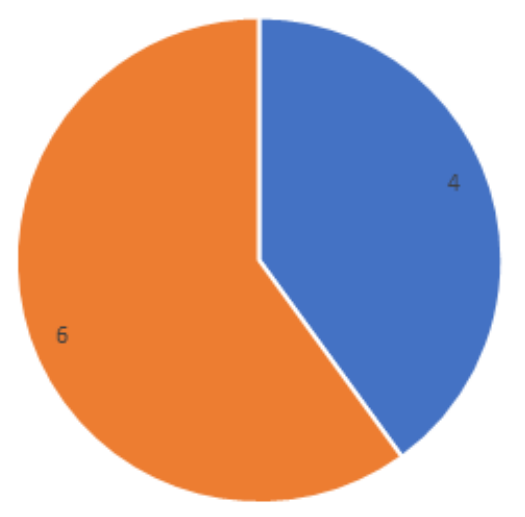

- Muheres em mestrado - Homens em mestrado

Fonte: Elaboração própria (2020).

Ao analisar essa figura percebe-se que em relação ao total de alunos formandos no curso de Comunicação Social da UFCG, cerca de 10\% optaram por ingressar em mestrado. De acordo com o total de homens egressos, esse dado é representado por 9,5\% que finalizaram ou ainda fazem mestrado; já em relação às 127 , mulheres esse dado cai para $3,1 \%$.

Com relação aos docentes efetivos do curso existe uma representatividade feminina de $45,45 \%$, como mostra a Figura 3, um valor bastante representativo visto que o ingresso em mestrado, pelo menos para o curso de Comunicação Social da UFCG, ainda é baixo. Homens representam um total de $54,55 \%$ do corpo docente ilustrado na Figura 3 com a cor laranja.

Figura 3 - Professores do curso de Comunicação Social

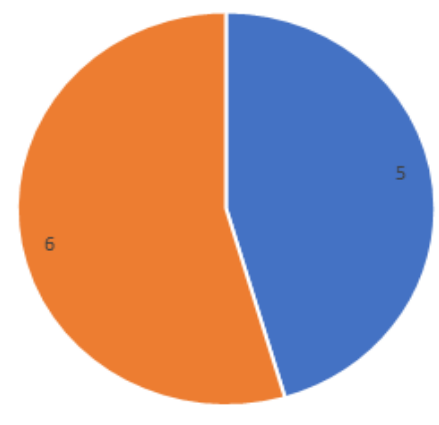

- Muheres " Homens

Fonte: Elaboração própria (2020). 
O corpo docente é formado por 11 professores efetivos, 5 mulheres e 6 homens, de acordo com o currículo Lattes, todas as mulheres são graduadas em Comunicação Social e suas demais habilitações e 3 dos 6 professores homens são graduados em Comunicação Social.

\section{CONSIDERAÇÕES FINAIS}

É notório que, mesmo no século XXI, a desigualdade de gênero seja algo ainda presente na sociedade. Os dados que constroem essa pesquisa mostram que as mulheres continuam a precisar percorrer um longo caminho, que vai além de anos e décadas de lutas, pois existe um forte fator cultural e histórico que fortalece o machismo.

Não restam dúvidas sobre a importância de criar movimentos e pesquisas que fortaleçam as lutas das mulheres por direitos igualitários, tendo em vista que a pesquisa deve ser algo que venha a pluralizar os conhecimentos. Sendo assim, entende-se que quando segregado seja por gênero, cor, sexualidade ou etnia se perde a oportunidade de grandes mentes poderem trabalhar e fazer grandes descobertas.

Portanto, diante das dificuldades encontradas pelas mulheres no mercado de trabalho, decidiu-se investigar como isso se desenvolve na área acadêmica, a partir de um estudo produzido entre os egressos do curso de Comunicação Social da UFCG. Este curso foi escolhido pela ausência de pesquisas que envolva o gênero sobre o curso, que completa dez anos de fundação, e pela possibilidade de acesso dos autores aos dados (na condição de aluno e professores do curso).

Seguindo a metodologia proposta, foi possível analisar os currículos dos egressos do curso de Comunicação Social da UFCG e notar que muitas mulheres optaram por novas graduações e especializações, o que pode acarretar na falta da busca pelo mestrado, ou por simplesmente não quererem seguir a carreira acadêmica. Apesar disso, pôde-se observar que ao longo dos anos a busca pela área acadêmica vem aumentando por parte dos graduados do curso.

Os docentes do curso de Comunicação Social da UFCG, por sua vez, têm uma representatividade feminina bastante forte, pois cerca de $45,45 \%$ do corpo docente é 
formado por mulheres e todas graduadas em Comunicação Social e suas demais habilitações.

É importante ressaltar que, ao pesquisar sobre os alunos que ingressaram em mestrado, foi possível notar que muitos dos egressos estão inseridos no mercado de trabalho, servindo então de motivação para as pessoas que estão graduando e sem perspectiva. Por fim, sugere-se que essa pesquisa possa servir de modelo para ser aplicado em outros cursos, com o intuito de quantificar esses dados e realizar um comparativo, ajudando assim a reforçar essa luta, que não cabe apenas às mulheres, mas a todos que deseja um mundo melhor, com mais igualdade de gênero e representatividade feminina na ciência e nos altos cargos da carreira acadêmica.

\section{REFERÊNCIAS}

ABREU, Maria Zina Gonçalves de. Luta das Mulheres pelo Direito de Voto. Movimentos sufragistas na Grã-Bretanha e nos Estados Unidos. Arquipélago Revista da Universidade dos Açores. Ponto Delgada, 2a série, VI, p. 166-199, 2002.

BRAGA, Marinilson. Curso de Comunicação Social da UFCG terá habilitação em Educomunicação: Graduação será voltada para elaboração e produção de mídias para os ensinos presencial e à distância. 2009. Disponível em: <http://www.ufcg.edu.br/prt_ufcg/assessoria_imprensa/mostra_noticia.php?c odigo=9488>. Acesso em: 04 nov. 2019.

ESCOSTEGUY, Ana Carolina. A contribuição do olhar feminista. Intexto, n. 3, p. 1-11, 1998.

ESCOSTEGUY, Ana Carolina. Stuart Hall e feminismo: revisitando relações. MATRIZes, v. 10, n. 3, p. 61-76, 2016.

FINCO, Daniela F. Relações de gênero nas brincadeiras de meninos e meninas na educação infantil. Pro-posições, v. 14, n. 3, p. 89-101, 2003.

FRANCHINI, B. S. O que são as ondas do feminismo? in: Revista QG Feminista. 2017. Disponível em: https://medium.com/qg-feminista/o-que-s\%C3\%A3o-as-ondasdo-feminismoeeed092dae3a. Acesso em: 19 de agosto de 2020.

JESUS, Milena Santos de. A abordagem conferida ao sexo e gênero nas distintas ondas feministas. Revista café com Sociologia, v. 3, n. 3, p. 188-206, 2014.

LEÃO, Giovanna Alves et al. A Educomunicação é Conhecida por Alunos do Ensino Médio em Escolas de Campina Grande? In: XIX Congresso de ciências da comunicação na região nordeste. Intercom - Sociedade Brasileira de Estudos Interdisciplinares da Comunicação. Fortaleza: Intercom, 2017. v. 19, p. 1-13. 
Disponível

em:

http://www.portalintercom.org.br/anais/nordeste2017/resumos/R57-0076-

1.pdf. Acesso em: 03 jun. 2020.

MARTINS, Ana Paula Antunes. O Sujeito" nas ondas" do Feminismo e o lugar do corpo na contemporaneidade. Revista Café com Sociologia, v. 4, n. 1, p. 231-245, 2015.

MONTENEGRO, Rosilene Dias; GONÇALVES, Hugo Feitosa; DA SILVA, Alla Gustavo Freire. Desenvolvimento e gênero: indicadores da participação das mulheres na ciência e tecnologia. Seminário Internacional sobre Desenvolvimento Regional, 2017.

MOREIRA, Josilene Aires; MATTOS, G. de O.; REIS, LuanaSilva. Um panorama da presença feminina na ciência da computação. Anais 18 REDOR-Perspectivas Feministas de Gênero: Desafios no Campo da Militância e das Práticas, Universidade Federal Rural de Pernambuco, Recife, p. 3527-3542, 2014.

NARVAZ, Martha Giudice; KOLLER, Sílvia Helena. Metodologias feministas e estudos de gênero: articulando pesquisa, clínica e política. Psicologia em estudo, v. 11, n. 3, p. 647-654, 2006.

O GLOBO. No Brasil, $26 \%$ acham que homem que fica em casa para cuidar dos filhos é 'menos homem'. São Paulo, 23 maio 2019. Disponível em:<https://oglobo.globo.com/celina/no-brasil-26-acham-que-homem-que-

fica-em-casa-para-cuidar-dos-filhos-menos-homem-23678970>. Acesso em: 21 out. 2019.

OLINTO, Gilda. A inclusão das mulheres nas carreiras de ciência e tecnologia no Brasil. Inclusão Social, v. 5, n. 1, 2011.

SILVA, Fabiane Ferreira da. Mulheres na ciência: Vozes, tempos, lugares e trajetórias. Dissertação de Mestrado. 2012.

SILVA, Fabiane Ferreira da; RIBEIRO, Paula Regina Costa. Trajetórias de mulheres na ciência:"ser cientista" e "ser mulher". Ciência \& Educação (Bauru), v. 20, n. 2, p. 449-466, 2014

SILVA, Sergio Gomes da. Preconceito e discriminação: as bases da violência contra a mulher. Psicologia ciência e profissão, v. 30, n. 3, p. 556-571, 2010.

SILVA, Tomaz Tadeu de et al. A produção social da identidade e da diferença. Identidade e diferença: a perspectiva dos estudos culturais. Petrópolis: Vozes, p. 73-102, 2000.

SOARES, Ismar de Oliveira. Educomunicação: o conceito, o profissional, a aplicação. São Paulo: Paulinas, 2011.

TABAK, Fanny. O laboratório de Pandora: estudos sobre a ciência no feminino. Editora Garamond, 2002.

VERGARA, Sylvia Constant. Projetos e relatórios de pesquisa. São Paulo: Atlas, 2006. 
WOELLNER DOS SANTOS, L.; YOSHIE ICHIKAWA, E.; CARGANO, D. de F. Ciência, tecnologia e gênero: desvelando o feminino na construção do conhecimento. 2006. 


\title{
CAPÍTULO IX
}

\section{TRANSFORMANDO A PRÁTICA: CONVERSANDO SOBRE DIVERSIDADE DE GÊNERO E SEXUAL}

Andreia Resende dos Reis ${ }^{1}$

\begin{abstract}
${ }^{1}$ Doutora em Psicologia. Referência técnica no ambulatório para atendimento a pessoas travestis e transexuais no Hospital Eduardo de Menezes/Belo Horizonte/MG - Servidora psicóloga da Fundação Hospitalar do Estado de Minas Gerais - FHEMIG.
\end{abstract}

\section{RESUMO}

O artigo teve como objetivo conhecer, através da técnica de rodas de conversas, a forma como agentes públicos na área da saúde, expressam suas impressões, conceitos, opiniões e concepções acerca da temática diversidade de gênero e sexual. a investigação foi realizada em um hospital da rede estadual de saúde do município de belo horizonte. a roda de conversa proporcionou motivar conversas oferecido através de um convite na qual foi conduzido 4 encontros com um grupo multidisciplinar, totalizando um número de 15 participantes. pode-se concluir que os resultados apontam para existência de indicadores de violência institucional no cotidiano de agentes públicos nessa instituição de saúde. consideramos também a abordagem difícil, pois emplaca entre outros fatores, posicionamentos pessoais e de julgamentos.

Palavras-chave: Narrativa. Roda de Conversa. Saúde.

\section{INTRODUÇÃO}

Foi desenvolvido o projeto de pesquisa: TRANSformando a prática: conversando sobre diversidade de gênero e sexual ${ }^{1}$ com o objetivo de analisar como agentes públicos de uma instituição pública de saúde definem as questões de gênero e sexualidade com recorte da temática sobre pessoas transgêneros, e como isso reflete em práticas sociais, especialmente no cotidiano do campo laboral. Esse projeto foi importante ser viabilizado, pois a instituição em particular passou a abrigar desde novembro de 2017 o primeiro ambulatório estadual de Saúde Integral para Pessoas Travestis e Transexuais.

${ }^{1} \mathrm{O}$ projeto é um desdobramento da pesquisa de doutorado intitulada "SOMOS FEITAS DE HISTÓRIAS": (auto)etnografia multilocal e produção de narrativas com travestis usuárias de um serviço público de saúde referência para doenças infectocontagiosas", defendida em 2018 no programa de pós-graduação em Psicologia pela Pontifícia Universidade Católica de Minas Gerais/Brasil. 
Neste artigo, não se pretende discutir o citado projeto, mas sim, alguns resultados que foram produzidos a partir de narrativas em formato de rodas de conversas. O projeto se orientou dentro da pesquisa qualitativa e as rodas de conversa serviram como estratégia para produção e ressignificação das narrativas de colaboradores da instituição sobre suas vivências com a temática tendo como premissa o reconhecimento da potencialidade da fala livre e espontânea.

Embora não seja o objetivo do estudo promover uma discussão teórica sobre gênero, entendemos ser importante localizar os leitores e leitoras sobre o meu posicionamento teórico. Para melhor compreensão da leitura, corroboro com o conceito produzido por Viviane Vergueiro (2016) ao se referir às pessoas transgêneras. Para a autora, transgêneros são pessoas que de muitas e variadas formas se sentem não conformes, constrangidas, desconfortáveis e/ou desajustadas dentro da categoria de gênero - homem ou mulher - que receberam originalmente ao nascer. Por isso mesmo, essas pessoas descumprem as normas do gênero no qual foram enquadradas a fim de expressarem a identidade de gênero com a qual se identificam e na qual se reconhecem. Entre as pessoas transgêneras estão as travestis, homens transexuais, mulheres transexuais e diversas outras expressões de gêneros. Já as pessoas que se encontram ajustadas e se sentem confortáveis ao rótulo de identidade de gênero - mulher ou homem - cuja "experiência interna e individual do gênero" satisfaçam ao "sexo atribuído no nascimento" a elas, são chamadas de cisgêneros. Por orientação sexual apoiamos no documento internacional Princípios de Yogyakarta(2006) que propõe o descentramento da noção de orientação sexual pautada no biológico e passa a considerá-la como uma referência à capacidade de cada pessoa de ter uma profunda atração emocional, afetiva ou sexual por indivíduos de gênero diferente, do mesmo gênero ou de mais de um gênero, assim como ter relações íntimas e sexuais com essas pessoas.

Sustentamos o presente estudo na perspectiva de que o desenvolvimento do conceito de gênero se explica pela existência de uma classificação binária das pessoas entre mulheres e homens e pelas conjunturas sociais e psíquicas que circundam cada um desses grupos dentro de uma sociedade sexista. De acordo com Scott (1989, p. 12) [...] gênero significa saber a respeito das diferenças sexuais. Tal saber não é absoluto ou verdadeiro, mas sempre relativo [...]. Assim, tal abordagem problematiza as categorias 
de "mulher" e "homem", ao sugerir que o feminino e o masculino não são características inerentes à dimensão biológica, mas constructos subjetivos, que, por consequência, aludem que a pessoa, ao longo de sua vida, esteja em um processo constante de construção e ressignificação. Nas palavras da autora: "Temos necessidade de uma rejeição do caráter fixo e permanente da oposição binária, de uma historicização e de uma desconstrução genuína dos termos da diferença sexual" (Scott, 1989, p. 84).

Desse feito, gênero para o entendimento de algumas pessoas, representa, antes de tudo, um código de normas de conduta estabelecidas socialmente, por meio de um dispositivo que naturaliza a heterossexualidade e, ao mesmo tempo, a torna compulsória. Essas condutas dizem de uma linguagem específica, de símbolos específicos e de modos característicos de ser e de agir das pessoas que reforçam a construção dos corpos femininos e masculinos. Nesses termos, uma matriz heterossexual é instaurada, a partir de "[...] leis que buscam estabelecer as linhas causais ou expressivas de conexão entre sexo biológico, gêneros constituídos culturalmente e a expressão ou efeito de ambos nas manifestações do desejo sexual nas práticas sexuais" (Butler, 2013, p. 72). A filósofa nomeia esse movimento de "heterossexualização da vida", de ordem compulsória do sexo-gênero-desejo, que rotula tanto as orientações sexuais como as identidades de gênero. Além disso, a imposição de um regime específico assegura que todas e todos devem se adequar à linearidade obrigatória entre sexo, gênero e sexualidade. O que se percebe, portanto, é que, nessa proposição, em todas as instituições sociais, todas as pessoas devem ser criadas para, a partir do sexo definido, corresponder a um gênero específico e à orientação sexual heterossexual. Butler (2013) critica exatamente essa ordenação e procura combater a crença difundida de que o sexo e o corpo são entidades materiais naturais e autoevidentes. O caráter homossexual, bissexual, lesbiano, por exemplo, das relações assumidas por mulheres e homens como forma que subverte a lógica da orientação sexual, e da pessoa transgênero, que subverte a lógica do gênero, inventam novos arranjos na interação social. Assim, constroem-se novos espaços de resistência às normas regulatórias. A compreensão das pessoas que escapam à ordem vigente descortina a heteronorma e amplia a possibilidade do repertório de identidades existentes. A filósofa argumenta que a identidade de gênero que não decorre do sexo e aquelas em que as práticas do desejo não decorrem nem do sexo nem do gênero não deveriam existir, dada a incoerência e a 
descontinuidade em função das leis instituídas, que estabelecem normas regulamentando a forma e o significado da sexualidade e do gênero.

Sobre Rodas de Conversa, o intuito não é aprofundar a discussão, pois implicaria em um debate que foge ao objetivo desse estudo, mas pretende-se somente apresentar, grosso modo, as bases que sustentam o trabalho com foco da conversação entre os agentes públicos. Desse turno, rodas de conversa constituem uma metodologia participativa (Afonso e Abade, 2008) que leva à criação de novos contextos de participação com propósitos crítico-colaborativos de agir. Entende-se ainda que nas interações colaborativas as conversas possibilitem encontros dialógicos, criando mecanismos de produção e ressignificação de sentido - saberes - sobre as experiências dos participantes. (Sampaio, Santos, Agostini, Salvador, 2014).

A escolha pelas rodas esteve ligada à possibilidadede criar espaços para o exercício da fala e ponto de vistas, inaugurando a produção e ressignificação de sentidos para as históricas e desiguaisrelações de gênero marcadas por preconceito, discriminação e estigma, que insistem em perdurar e vulnerabilizar pessoas transgêneros.

\section{CORPOS PRECARIZADOS}

A violência institucional é conseqüência do excesso poder no uso da autoridade profissional em relação aos usuários de um serviço. Ou segundo afirmam Azeredo e Schraiber (2017) "[...] quando a autoridade profissional se esvazia e as relações entre os homens não se dão mais através das relações de poder é que está aberto o espaço para o fenômeno da violência". A violência institucional limita e provoca a falta de acesso aos serviços levando à má qualidade e a abusos cometidos em virtude das relações de poder desiguais entre profissionais e usuários e usuárias dentro das instituições.

Apresentando as reflexões de Judith Butler como aporte teórico acerca dos conceitos de 'violência', neste caso institucional e 'poder', objetiva-se conjugar essas reflexões com as narrativas dos conversadores na roda de conversa que foram em sua maioria, expressas por meio de relatos muitas vezes naturalizados e não reflexivos levando em todo o seu percurso, a uma reflexão nada densa que se concentram em falas de falta de (re) conhecimento desse outro, portanto, demarcado relações que 
precedem o cotidiano de discriminação e estigmatização para com as pessoas trangêneras.

Para Butler (2013), todo tipo de violência é destrutiva, seja ela a física ou a que está impressa na norma de forma compulsória pelos padrões da heteronormatividade que, de fato, opera com a sua força e a sua potência máxima reveladas na violência que inclui as institucionais, e que ocorre na existência de minorias. A autora sugere que o mais importante é entender o modo como essas formas de violência trabalham entre si. Assim, a filósofa salienta que, a partir desse discurso, ter uma vida, ser reconhecida como uma pessoa, uma cidadã ou cidadão, não é para todos. A partir do pensamento da autora, a vida, constituída por uma normatividade sobre o corpo, se torna "precária" pela instituição da exterioridade ao mundo, ou seja, por um aspecto fragmentado ou total do contato com o mundo; é por isso que Butler expõe o corpo como um "fenômeno social: [...] que está exposto aos outros, [...] e que é vulnerável por definição" (Butler, 2015, p. 57-58). Dessa forma, a violência para a autora pode ser entendida, quando há ruptura da coerência da heteronorma sobre os corpos. Essa ruptura altera a noção de heteronormatividade eclodindo a violência que advém desse construto social e leva "[...] a um construto sem vida, um construto feito para mortificar o corpo" (Butler, 2013, p. 182). Nesse contexto de rupturas, observamos diferenças na dinâmica de funcionamento da heteronormatividade aparecendo como terreno fértil e privilegiado para a violência operar. Trata-se de perceber que a violência, seja ela verbal, da injúria, das palavras que agridem, das representações que ofendem, dos olhares, da agressão física, configura as pessoas trangêneras como abjetos pela subversão de suas identidades de gênero. Nesse sentido, as pessoas trangêneras são vistas pelos padrões da heteronorma como corpos precarizados, corpos violados, desprovidos de reconhecimento e de representação. São corpos expulsos dos espaços públicos por meio de uma violência que aparece na sua produção/exclusão. O mesmo pode ser dito, quando o poder-saber,ordenando e regulando as pessoas de acordo com normas estabelecidas, colocam-se diante da situação que "[...] efetivamente, decidem quais vidas serão reconhecíveis como vidas e quais não o serão [...]" (Butler, 2015, p. 28), a fim de criar hegemonia, suprimindo, assim, as possibilidades de existência dessas pessoas. Esse aspecto corrobora com as nossas observações na interação da roda de conversa quando os conversadores falaram de forma às vezes, sutis e outras não, da 
repulsa à essaspessoas, das suas necessidades de se autoafirmarem dentro do gênero baseado no biológico e da vulnerabilidade do outro: "Se certas vidas não são qualificadas como vidas ou se, desde o começo, não são concebíveis como vidas, de acordo com certos enquadramentos epistemológicos, então, essas vidas nunca serão vividas nem perdidas no sentido pleno dessas palavras" (Butler, 2015, p. 13).

A autora recomenda que "Antes de julgar o outro, devemos ter algum tipo de relação com ele" (Butler, 2015, p. 40). O enquadramento, segundo Butler, parte dos discursos que modelam, classificam, hierarquizam e enquadram a vida de minorias. Esses enquadramentos", segundo a autora, "[...] atuam para diferenciar as vidas que podemos apreender daquelas que não podemos [...]" (Butler, 2015, p. 17). Amiúde, o enquadramento normativo determina a própria violência.

\section{OPERACIONALIZANDO O MÉTODO DA RODA DE CONVERSA}

No final de dezembro de 2018, apresentei o projeto de pesquisa individualmente a alguns colegas de trabalho de diversas categorias profissionais. Utilizei essa estratégia do contato individual com os participantes da pesquisa, no sentido de não criar um contexto no qual os participantes se sentissem pressionados a participar da pesquisa pela chefia de cada setor da unidade hospitalar. Na medida em que esses funcionários interessados na pesquisa se manifestavam, os encontros eram agendados. Foram realizadas quatro encontros com grupos de pessoas diferentes, totalizando 15 participantes distribuídas nas seguintes categorias profissionais: um médico, duas recepcionistas, nove enfermeiras, uma assistente social e dois técnicos de enfermagem. Todas as rodas de conversa foram áudio-gravadas e tiveram duração de 45 a 100 minutos. Os encontros ocorreram nas três primeiras terças-feiras do mês de fevereiro de 2019, seguindo a conveniência da equipe. A Roda aconteceu num local próprio para treinamentos e capacitação do próprio hospital.

Iniciei cada encontro solicitando uma breve apresentação entre os participantes da pesquisa e posteriormente foi apresentando novamente os objetivos da atividade e os procedimentos a serem adotados. Nesse momento, solicitei permissão das pessoas que aceitaram o convite para participar da pesquisa para gravar as discussões assegurando o anonimato e o caráter sigiloso e esclareci que, por questões de ética em pesquisa envolvendo seres humanos, que tal procedimento requer a assinatura do 
Termo de Consentimento Livre e Esclarecido (TCLE). Após, convidei o grupo a discutir sobre a temática diversidade de gênero e sexual e quais eram suas experiências no campo profissional em relação ao atendimento à população de transexuais e travestis, e solicitei aos participantes a ilustrarem suas falas com experiências vividas no cotidiano do trabalho na instituição de saúde.

Desde o início, eu sabia que discutir a temática de gênero e sexualidade poderia ser delicado apesar desse tema ter ganhado cada vez mais visibilidade. Na mídia, relatam-se diariamente assassinatos e mortes de travestis e outras pessoas transgêneras, sejam em um contexto de prostituição, por crimes transfóbicos, por doenças ou suicídios, e em programas de televisão e reportagens com discussões sobre gênero e sexualidade. Especialmente nos últimos anos, acompanhamos os debates, muitos deles edificados no biológico e na heteronormatividade, que ganharam bastante repercussão quando se tratou da terapia de conversão, reversão, readequação ou reorientação de identidade de gênero das pessoas transexuais e travestis. Para o engajamento dos participantes da pesquisa eles precisariam se sentir confortáveis e seguros. Assim, alguns combinados foram feitos no sentido de garantir que os conversadores pudessem se ver e ter espaço para mobilidade, e também não foram definidos procedimentos estanques como ordem de fala, para casos de pessoas com dificuldade de se expressar. Foi enfatizando que as narrativas fossem sempre produções voluntárias, respeitando os limites de cada um e de cada uma, não forçando ninguém a narrar experiências vivenciadas no cotidiano do trabalho e que o espaço, sobretudo, fosse ofertado como trocas entre os conversadores. Assim, focalizo uma interação dialogada (Spink \& Medrado, 1999), isto é, a produção de narrativas particulares e os posicionamentos contrastantes entre os participantes não devem ser evitados. Diante disso, o foco recai simultaneamente no produto e nas trocas, nos quais os resultando incidem em deslocamentos, tensões e contrastes. Corroboramos com esses autores quando eles afirmam que "[...] todo grupo produz sua própria dinâmica, e o pesquisador, certamente, não é capaz de apreender plenamente os diversos jogos simbólicos que possam ser gerados no momento da interação em grupo." (p.34).

O grupo de certa forma ficou tranquilo, pois perceberam que estávamos ali para conversarmos e não para uma atividade de treinamento em educação em saúde, como é rotina da instituição quando é obrigatório nos formatos de Educação Continuadas. No 
processo de me tornar-se uma participante daquele grupo, o objetivo foi estimular a produção e ressignificação das narrativas da equipe por meio de problematizações, de troca de informações e de reflexão sobre o tema. A equipe entendeu que aquele espaço era um ambiente convidativo no qual eles poderiam falar sobre o assunto tão caro para muitos sem muitas reservas e sem medo de serem rechaçados pelas chefias setoriais.

Dentre as dificuldades na realização das rodas, a primeira enfrentada e que se manteve ao longo de todo o processo das rodas de conversa foi a articulação com os servidores; compromisso de comparecimento firmados antes da pesquisa e que não se confirmaram no dia dos encontros, resultando em absenteísmo, sendo o número médio de servidores por roda passou a ser de quatro. Uma semana antes de cada roda de conversa, foram feitos contatos através de envio de mensagens no WhatsApp, lembrando-os da atividade. Algumas pessoas confirmavam a presença ou a não participação imediatamente no ato do recebimento da mensagem, outras, em outro momento, justificavam a ausência em formas de esquecimento, plantão corrido ou outro compromisso no mesmo horário, ou ainda, não responderam. Para ter maior adesão dos servidores, a roda acontecia no horário de trabalho, em que os funcionários já estavam na instituição. A alegação de muitos servidores se sentirem desmotivados em participar das rodas, e participar de qualquer outra atividade ofertada está embasada na calamidade econômica que o Estado de Minas Gerais com cortes em benefícios, parcelamentos de salário e na época das atividades o governo ainda não havia anunciado a data de pagamento do décimo terceiro salário dos servidores públicos e baixa valorização do funcionário.

Esta pesquisa seguiu os trâmites éticos e legais para pesquisa envolvendo seres humanos conforme Resolução 466/12 do Conselho Nacional de Saúde (Brasil, 2012). Foi submetida à Plataforma Brasil e aprovada pelo Comitê de Ética em Pesquisa (CEP) da $X$ com número de parecer XX e no CEP XXX - Parecer Técnico número XXXX e no CEP XXXXX.

A organização do material empírico produzido durante a roda de conversa será apresentando compondo o texto do artigo inspiradas nas narrativas ficcionais de Marcos Reigota (1999). Adotamos essa metodologia por dois motivos: o primeiro foi o de nele reunirem-se as diferentes narrativas de profissionais de saúde no contexto das rodas de conversa e/ou da convivência cotidiana, especialmente no trabalho, e/ou em outros 
espaços sociais. O segundo motivo que nos levou a utilizar as narrativas ficcionais foi a possibilidade de, diante das histórias, saber utilizar informações confidenciais e outras experiências, sem ferir, delatar, denunciar, a fim de evitar a exposição dessas pessoas com as quais tenho relações profissionais, sociais e afetivas. Dessa maneira, cortei cada história em vários fragmentos e, embaralhando-as, fizemos uma espécie de colagem, criando novas histórias, baseadas em fatos reais, mas que devem ser lidas como ficção, as quais serão expostas em formatos de pequenos trechos. Assim, "[...] nenhum personagem pode ser encontrado na vida real conforme descrito, pois nenhum é reflexo de uma única pessoa" (Reigota, 1999, p. 74).

\section{PRODUÇÃO DAS NARRATIVAS}

As Rodas de Conversa, ao evidenciar que alguns posicionamentos preconceituosos não são experiências individuais, mas também são vivenciadas por outros servidores produzem um papel fundamental na estigmatização desse grupo de pessoas transgêneras. Merece destaque o relato de uma servidora, emblemático da socialização das ideologias de gênero, no que tange à transexualidade "Quando nasce, já está definido: é menino ou menina". Outra servidora acrescenta: "A gente vai pelo sexo exposto. Pelo biológico. Eu vim de uma cultura que homem é homem e mulher é mulher." Em algumas situações, as narrativas, além de não problematizarem as experiências relatadas, reforçavam preconceitos e discriminações. Assim "Estávamos acostumados com dois gêneros, agora vem essa quantidade de termos e letras". Em outra narrativa, investida de preconceitos e carente de discussões, uma servidora diz: "Às vezes, nem eles entendem o que se passam com eles e exige que nos saibamos. Querem que a gente absorva a cada dia, uma letrinha. Gente!!! não é bem assim...". Expressões desse tipo, que pode ser também de qualquer outra formar - pode ser um olhar, um pensamento, uma pergunta equivocada, só materializa o preconceito e discriminação para com essas pessoas. Em reboque, o que se observa, que o processo pelo qual pessoas transgêneras demandam o reconhecimento social de seu gênero, exige o deslocamento dentro de uma perspectiva que imagina o gênero como algo decorrente da genitália e que não concebe outras possibilidades como legítimas. Neste caso o gênero revelaria "[...] o que nossas genitálias informam" (Berenice Bento, 2006). As narrativas, além do efeito discriminatório, entoa ao som de muitas outras vozes que 
agem e pensam dessa maneira impedindo que as pessoas transgêneras possam ter a garantida sua dignidade e o respeito de sua existência como possível, legítima e real. Tal posicionamento produz fissuras nas relações de cuidado e configura-se como uma violência institucional que tem reflexos direto noâmbito da saúde dessas pessoas, colocando-as em situação de maior vulnerabilidade. Como observa Prado (2018), há uma repetição no reforço de séculos de produção em série de ações que só enxergam nos outros desvios, doenças, distúrbios, perversões, incoerências, suspeitas e anormalidades. Pelo direcionamento foucaultiano dos micropoderes e das tecnologias disciplinares, isso se dá, pelo viés de discursos dispositivos religiosos, jurídicos, médicos e pedagógicos.

Em outro momento de uma roda, por exemplo, algumas pessoas reforçaram a patologização da diferença, afirmando que a transexualidadeé um desvio produzido por processos educativos equivocados. "Eu penso assim, que isso acontece porque os pais não souberam educar com um pulso firme e acaba deixando o filho livre. Então a gente como pai, como mãe tem que agir. Pegar firme desde criança." Narrativas dessa natureza foram compartilhadas no e pelo grupo "Não é porque a criança botou isso na cabeça sendo menino, que se quiser ser menina, que ele pode, que ele vai ser. Os pais não precisam falar isso, não pode apoiar. É dever dos pais ir tirando isso da cabeça do filho." A naturalização do gênero, em alguns momentos, aparecia novamente como ferramenta de patologização. "Às vezes quando a gente olha pra algumas pessoas... é que parece que tem uma indefinição. Se é homem, se é mulher, se é trans, se é travesti... o que eu percebo diante disso tudo, é que são pessoas que não estão padronizadas dentro daquilo que inicialmente é natural". O World Professional Association for Transgender Health (WPATH) $(2012$, p. 05) encoraja a despatologização da variabilidade de gênero em todo o mundo e afirmou que:

“a expressão das características de gênero, incluindo as identidades, que não estão associadas de maneira estereotipada com o sexo atribuído ao nascer, é um fenômeno humano comum e culturalmente diverso que não deve ser julgado como inerentemente patológico ou negativo".

Outras experiências apresentadas pelos conversadores dão conta de como esses agentes do Estado promove exclusões levando a processos de violência e violações de direitos. "Nós mulheres queremos o nosso espaço; se elas são trans deveriam querer os 
espaços delas". Em uma narrativa foi dito: "Cada um no seu quadrado. Que ela é feliz no seu quadrado, que assim seja. Se quer ser trans, quer ser mulher, seja no espaço dela". Em continuidade outro conversador diz: "Aqui a gente trabalha com isso, com pessoas diferentes, eu falo isso porque eles são diferentes". Em seguida, outro afirma "Eu respeito eles com o gênero deles, agora eles tem que respeitar o nosso. Querem ser igual a gente, aí não dá". As narrativas produzidas diziam de uma descrição que ao mesmo tempo em que produzia a separação (eles/nós) homogeneizava ambos os lados dessa divisão, assunto trabalhado por Mosqueta (2012) - como se os usuários transgêneros, juntos formassem parte de um único grupo, e por oposição, a equipe ou ao nós, fosse parte de outro, completamente distintos. Esta divisão ficou ainda mais nítida quando eu solicitei ao grupo que refletisse sobre o que queriam dizer quando afirmavam "respeitar o gênero do outro, ou respeitar o outro". Diante dessa reflexão, alguns permaneceram em silêncio, outros riam buscando justificar suas posições afirmando: "Então gênero é masculino e feminino, pênis e vagina, no biológico mesmo. Não tem que ficar inventando moda". As narrativas construídas modelam, classificam, hierarquizam e enquadram a vida dessas pessoas. Tais saberes-poderes sobre os corpos fixam sujeitos e forjam fronteiras muitas vezes intransponíveis no qual a acepção binária homem-mulher, masculino-feminino, pênis e vagina é a adequada e o que foge desse campo se configura patologia.

De acordo com Benevides e Aguiar (2018) o preconceito e a discriminação está:

[...] diretamente relacionada à falta de discussões amplas sobre o tema, a fim de manter os privilégios daquelas pessoas que nascem com a estrutura pensada para si, em detrimento daquelas que vivenciam uma forma diferente de existir, o que lhes impõe diversas barreiras no transcurso de suas vidas. (43).

Prevalece distanciando de reflexões mais profundas quando uma conversadora diz "Eu acho que a gente tem que agir da maior naturalidade possível, a pessoa escolheu ser tratada assim e a gente tem que tratar assim". A performatividade, ou como diz a participante "agir natural" denuncia a capacidade que as palavras têm de produzir efeitos, de fabricar coisas, nem sempre desejáveis ou previstas em sua enunciação original. (Azevedo, Medrado, Lyra, 2018). É interessante perceber que boa parte dos conversadores mantiveram um discurso da igualdade sem uma reflexão crítica mais aprofundada sobre o que é ser igual ou diferente "todo mundo vai tratar igual." "Pra 
mim, todo mundo é igual. É assim... a gente vê eles diferentes, mas tem que tratar igual." "Não é tratar de forma desigual. Mas não dá pra misturar". As pessoas transgêneras foram caracterizados por sua diferença, sua singularidade, com tom estigmatizado.

A oportunidade de refletirem acerca da temática e de aspectos constitutivos da profissão de cada um e como lidam com as pessoas transgêneras, produziram narrativas que também apontarem esse grupo de pessoas como exóticas. A elaboração do grupo partia de um universo do exagero, das cores, dos excessos ao se referirem às mulheres transexuais e travestis. "Elas parecem um pouco com o feminino, mas nem tanto. É um exagero até desse feminino. Às vezes, nos como mulheres não colocamos tanto personalidade no nosso feminino" O modo como percebiam essas pessoas, no sentido das relações que se desenvolvem com elas é muito solidário entre os conversadores, mas não contribuiu para a reflexão coletiva do grupo que não se apoiasse na estigmatização dessas pessoas. "É muita papagaiada que elas usam. Pra ser mulher, eu não preciso sair de vestido e salto. Eu já sou mulher.". Sem conseguirem deslocarem o eixo de análise da esfera de posicionamentos individuais para uma análise do cuidado em saúde, alguns conversadores afirmaram: "É sair de um estereótipos para outro e aprece que a pessoa gosta de viver além daquilo que foi dado. Não tem jeito, gente, não tem como forçar a barra. Em continuidade outra afirma: "Quanto mais extravagante melhor pra elas. Isso é doença, gente!" “Eu vejo que há mais uma mudança de aparência: é mais cabelo, mais jóias, mais maquiagens, mais cores, mais seios, mais salto, mais tudo. Pra que isso? É uma super afirmação de uma mulher". Butler (2013) diz que as pessoas que vivem a "incoerência de gênero" são entendidas, como "seres abjetos". Para a autora, o abjeto é um processo discursivo, residindo na linguagem como conteúdo não questionável. Seriam discursos colocados em pauta e naturalizados, desprovidos de olhar crítico. Dessa forma, viver, por exemplo, a experiência da transexualidade, cujas identidades são consideradas como marginais e não importantes no contexto da heteronormatividade, vivem suas identidades de gênero adotadas e assumidas à custa da exclusão brutal de suas subjetividades.

Além do estigma de pessoas transtornadas que carregam, patologias outras foram lançadas a esse grupo por mero preconceito e desconhecimento. “Quando falaram que iam abrir esse ambulatório trans, os próprios médicos assustaram porque disseram que ia aumentar o número de atendimento da infectologia". As reações iniciais 
no serviço de saúde foram marcadas pelo preconceito e também como alvo de intervenção. Assim, embora essa associação seja falsa e fomentada por práticas inventadas, ao mesmo tempo a população transgênera é recebida pelos profissionais da área e demandará desses profissionais um esforço na criação de uma resposta à desconstrução de conceitos para tornar o acesso aos serviços de saúde a eles mais igualitária. Conforme a literatura mostra, pessoas transgêneras restringem a procura por serviços de saúde por temerem serem discriminadas. (Moscheta, 2011; Guaranha, 2014; Guimarães, 2015; Santos, 2015, X (2018) inserir após análise).

E ainda por falta de informação, associam-na em uma triangulação definida pela maneira nem um pouco indulgente: transgêneros, hiv e prostituição: "Eles não podem se prostituir tanto. Não é porque é um trans ou um travesti que tem que levar a vida na prostituição.". Em outra narrativa, um conversador expõe: "Então vai ser bom... como eles como tem o vírus, aqui eles podem se cuidar também. Acho que aqui foi o melhor lugar para abrir o ambulatório". Ainda apoiados em vivências preconceituosas, uma conversadora afirma: "Aqui eles podem mudar de vida e seguir o caminho certo". A expressão "mudar de vida", diz respeito a " sair da prostituição" e a "reversão do gênero". Na pior das hipóteses, oferece poucas possibilidades e saídas para essas pessoas, alimentando a crença de que todas elas estão em um inevitável acento paliativo (Moscheta, 2011). Essas manifestações são em decorrência de processos sociais estigmatizantes, marginalizadores, excludentes e prejudiciais enquanto forma de descrever um "modo de ser" limitando o acesso a um conjunto de recursos importantes e essenciais para a construção da saúde e afirmação de identidades dessas pessoas.Assim, no que se refere às relações de cuidado, percebe-se como estas se desenrolam em meio a negação da existência da pluralidade das identidades, por vezes, a identidade de gênero dos usuários não é respeitada.

A análise de uma conversadora em torno de enquadramentos existentes, neste caso baseados em dogmas religiosos, propõe uma possível solução para encerrar o assunto nas temáticas do gênero, da sexualidade e da identidade: "Deus criou o homem e a mulher e pronto". Amiúde, esta posição é corroborada por outra conversadora: “Meu Deus! Eu fico pensando onde isso vai parar?E sem buscar compreender a transgeneridade, apresenta de forma superficial falas de intolerância e coerção: “ Porque eu fico muito preocupada com isso, porque isso começa na infância. Quer dizer, 
vai ser um jovem, um adulto com esse comportamento. Os pais tem que agir, a escola não pode deixar isso, e nos aqui temos que colocar ordem". Tais narrativas apropriadas de posições individualistas de discursos dogmáticos coloca a diversidade de gênero como desvio, anormalidade, como pecado sem abertura de um entendimento na perspectiva social. A naturalização dessas narrativas, não oferece muita saída àqueles que sofrem fomentando no campo da saúde, as demais formas de discriminação e preconceitos gerando violência contra essas pessoas e destituindo-as dos direitos conversados em leis (Moscheta, 2011).

Mesmo diante dessas falas, foi possível testemunhar, em alguns momentos, esboços de tentativas de maior aprofundamento nas questões "As pessoas estão se libertando como antes não se libertavam, saindo mesmo do armário. Mas eu não sei... a impressão que eu tenho é que parece que é uma coisa que vai se estruturando cada vez mais. Por sua vez, pode-se observar outros encontros nos quais os colabores partem do reconhecimento de que existem outras constituições de identidades, porém ainda com desconfianças, sobretudo, porque suas justificativas partes de uma visão da sociedade na qual a binaridade de gênero é a norma.

Em outros fragmentos de narrativas, observa-se outras tentativas de explicações e modos de convivência social "Isso é importante para dar visibilidade a elas." "Disso tudo, eu vejo que muitos funcionários têm é resistência, é preconceito mesmo. As pessoas são preconceituosas". "Agora está tudo escancarado. Antes quem era gay, era o gayzinho, ficava incubado, infeliz, morriam, suicidavam. Hoje ainda tem isso, mas acho que menos. Hoje eles têm voz, tem representatividade, buscam direitos, tem quem os ouvem" Por meio desses fragmentos de narrativas, é possível acessar não apenas trajetórias de vida, mas também sentimentos, crenças e posicionamentos desses servidores.

E continuam: "A sociedade não tem respeito por essas pessoas. Pela opção dessas pessoas. Às vezes, ele não escolheu ser assim. Ele nasceu assim. Ele é assim. E as pessoas lá fora não entende isso." "Eles tem que ser aceito em todos os lugares, trabalhando com dignidade e procurando melhorar a cada dia a saúde deles". Observase que mesmos narrativas compensatórias que criam maneiras de amenizar, ainda assim, é pulsante o estigma, discriminação dirigido a essas pessoas, configurando a vulnerabilidade social que elas estão sujeitas. 


\section{CONSIDERAÇÕES FINAIS}

Parte-se do pressuposto que o lugar da assistência à saúde deveria ser o de contribuir coletivamente com seus conhecimentos para romper as barreiras erguidas e fomentadas por preconceito, discriminação, estigmatização e violação de direitos. No que tange aqueles que expressam suas orientações sexuais e identidades de gêneros diferentes daqueles ditados pelos discursos que pressupõe, dentro do regime social, a heterossexualidade, na qual haja uma correspondência entre o sexo enxergado pela medicina durante o nascimento, a situação é diferente. Como vimos, a falta de preparo para o acolhimento de pessoas transgêneras, a falta de atenção de suas demandas por parte dos profissionais, e ainda a condição patológica em que as experiências são interpretadasfomentam dinâmicas de exclusão e violentam suas experiências. Dessa forma, nos apoiamos nas ideias Souza e outros (2015) que afirmam que a atenção integral à saúde precisa atender às demandas de forma que respeite as perspectivas, as expectativas, os desejos e o lugar de fala das pessoas transgêneras, mas, sobretudo, na eficiência e humanização nos serviços não de acordo com o ponto de vista individual dos profissionais envolvidos.

A intenção em utilizar as rodas de conversas baseou-se na possibilidade de favorecer a fala, aos colaboradores sobre assuntos social e moralmente "proibídosdesviantes-patológicos", possibilitando questionamentos, pontos de vistas, posicionamentos éticos-políticos, reflexões e, muitas vezes, a desconstrução de préconceitos, estereótipos, dúvidas, criticas e mitos a cerca do assunto. Dessa maneira, o projeto se sustentou na aposta de um estudo que agenciasse, no ato de sua própria produção, com um caráter não normativo e moralistas, efetivando a democratização à abertura de espaços reflexivos e dialogados entre diversos colaboradores que vivem e convivem no mesmo espaço do trabalho e em sua maioria lida diretamente no cotidiano do trabalho com pessoas transgêneras. Buscou-se favorecer a emancipação, sentidos e significados através do acesso à informação dialogada entre eles, bem como a reconstruir representações não apenas sobre pessoas transgêneras, mas também sobre si mesmos, seus papéis, nas relações sociais e de cuidado. As conversas suscitaram em narrativas muitas vezes polêmicas e revestidas de preconceitos, especialmente entendidos como pessoas indesejáveis e reforçados por estigmas de doença, 
anormalidade, desadaptação. Apesar de narrativas terem se mostrado problemáticas nas práticas institucionais para o contexto de saúde, elas certamente não atendem à demanda da população transgênera e repercutem negativamente contribuindo para aumentar parte do sofrimento vivenciado por essas pessoas. No entanto, algumas narrativas, além de explicações do ponto de vista científico, povoaram o interior das conversas confrontando práticas individualizantes que prejudicam a atuação profissional. Mesmo não legitimados por muitos que estavam presentes, acabaram por influenciar não apenas em posicionamentos mais individuais, que serviram em certa medida de intervenções por algumas razões a pensar: sobre questões envolvendo variáveis institucionais, a responsabilidade como profissional da saúde e como poderiam contribuir para que as pessoas transgêneras pudessem de fato ter acesso aos seus direitos no campo da saúde e como exercê-los; como poderiam na relação profissional manter uma postura de respeito ao usuário e usuária como sujeitos de direitos. E, por fim, a conversação também refletiu sobre suas próprias dificuldades, especialmente relacionada à valores morais, dogmáticas e/ou autoritárias repercutidas tanto através de posicionamentos pessoais como sem reflexões cristalizadas historicamente.

Sem dúvida, o impacto destas experiências sobre a vida de cada um colaborador nas rodas de conversa, propiciou um encadeamento de pontos de possível intervenção, atingindo o objetivo proposto neste estudo. Em resumo, foi possível identificar pelo menos três pontos que foram levantados nas rodas de conversa que sugeriram como marcos iniciais para as futuras oficinas de intervenções em saúde da população transgênera. Tais pontos, qual com sua perspectiva, certamente será proposta de intervenção e foco de ação no futuro. No primeiro ponto, vimos que as narrativas dão conta de classificações dos gêneros binário baseado no biológico, o que foge a isso, parte da perspectiva da patologização. No segundo ponto, as narrativas foram organizadas com foco moralista no estilo de vida desse grupo social e pela via da do discurso da patologia, construíram pessoas descritas como exóticas, curiosas, envolvidas no mercado da prostituição e portadoras de hiv. O terceiro ponto, se consolida a partir de narrativas mais coerentes com as políticas públicas voltadas para a garantia dos direitos humanos, cujas falas incluem estratégias terapêuticas que incluem o combate à discriminação e ao preconceito. Assim, conforme Moscheta (2011) saímos (pelo menos conceitualmente) das práticas corretivas, passamos às ações preventivas e chegamos ao 
combate à discriminação com vista a favorecer um atendimento à saúde digno e de qualidade a essas pessoas.

Por fim, os resultados obtidos neste estudo sugeriram que a criação desse espaço, por vezes orientado para ser colaborativo-crítico por meio da roda de conversa, promoveu mesmo que sutis, transformações nos modos de agir dos servidores, favorecendo a possibilidade de refletirem sobre a sua atuação profissional, observando que algumas vezes, as intervenções por parte de alguns conversadores, levaram a uma argumentação orientada para o convencimento e não para a negociação compartilhada.

Compartilhamos as ideias de Prado (2018) quando o autor se posiciona como um pesquisador de instituições públicas, que "[...] a despeito de tantas mazelas sofridas nos últimos tempos, perseguimos muitas experiências por necessidade, por necessidade de continuar pensando, se revendo e se reconstruindo e isso tem implicado muitos de nós a estar envolvido em atividades sempre bastante densas".

E foi assim, caminhando não tão livremente pelos corredores do SUS, cerceada por forças e poderes-saberes operando sobre nossos corpos, sobre os corpos inconformes que desenvolvi este estudo com toda a reflexão que a temática merece.

\section{REFERÊNCIAS}

Afonso, M. L. M. \& Abade, F. (2008). Para reinventar as Rodas. Belo Horizonte: Rede de Cidadania Mateus Afonso Medeiros (RECIMAM), Publicação eletrônica.

Bento, B. (2006). A Reinvenção do Corpo: sexualidade e gênero na experiência transexual. Rio de Janeiro: Garramond.

Butler, J. (2013). Problemas de gênero: feminismo e subversão da identidade. (5a ed.). Rio de Janeiro: Civilização Brasileira.

Conselho Federa de Psicologia. (2013). Nota técnica sobre processo transexualizador e demais formas de assistência às pessoas trans. Recuperado a partir de https://site.cfp.org.br/wp-content/uploads/2013/09/Nota-técnica-processoTrans.pdf

Conselho Federal de Psicologia. (2018).Recuperado a partir de cfp.org.br/despatologização.

Carvalho, G.C.M. O financiamento público federal do Sistema Único de Saúde 1988-2001 [tese]. São Paulo: Faculdade de Saúde Pública; 2002. 
Guaranha, C. (2014). O desfio da Equidade e da Integralidade: travestilidade e transexualidade no Sistema único de Saúde. Dissertação (Dissertação de Mestrado, Universidade Federal do Rio Grande do Sul, Programa de PósGraduação em Psicologia Social e Institucional). Recuperado a partir de http://www.lume.ufrgs.br/bitstream/handle/10183/115052/000956446.pdf

Guimarães, A. (2015). Todas as mulheres do mundo: a construção do corpo travesti no Brasil das décadas de 1960 e 1970. In: Brasil. Ministério da Saúde. Secretaria de Gestão Estratégica e Participativa. Departamento de Apoio à Gestão Participativa. (Org), Transexualidade e travestilidade na saúde. (pp. 39-64). Brasília: Ministério da Saúde.

Moscheta, M. dos S. (2011). Responsividade como recurso relacional para a qualificação da assistência a saúde de lésbicas, gays, bissexuais, travestis e transexuais. (Tese de Doutorado, Universidade de São Paulo, Faculdade de Filosofia. Ciências e Letras de Ribeirão Preto - Programa de Pós-Graduação em Psicologia, São Paulo). Recuperado a partir de wwww.teses.usp.br/teses/disponiveis/59/59137/tde.../Responsividade_Tese_ Moscheta.pdf

Prado, M. A. M. (2018). Ambulare. Belo Horizonte (MG): PPGCOM UFMG.

Reigota, M. (1999). Ecologistas. Santa Cruz do Sul: EDUNISC. Reis, A. dos \&Kind, L. (2015). A saúde de homens presos: promoção da saúde, relações de poder e produção de autonomia. Psicologia em Revista, 20 (2). Recuperado a partir de http://periodicos.pucminas.br/index.php/psicologiaemrevista/article/view/P.1 678- 9523.2014v20n2p212

Resolução no 1, de 29 de Janeiro, 2018, que estabelece normas de atuação para as psicólogas e os psicólogos em relação às pessoas transexuais e travestis. Recuperado a partir de cfp.org.br/wp-content/uploads/2018/01/Resolução-CFP01-2018.pdf

Santos, A. R. T. (2015). A Atenção Básica à Saúde no truque: o encontro das travestis e as agentes comunitárias de saúde no bairro Rio Branco em Belo Horizonte. (Dissertação de Mestrado, Universidade Federal de Minas Gerais, Programa de Pós-Graduação em Psicologia, Belo Horizonte. Recuperada a partir de www.fafich.ufmg.br/.../277/DISSERTAÇÃO\%20Anne\%20Rafaele\%20(Lançada).p df

Scott, J. (1999). Experiência. Falas de gênero: teorias, análises, leituras. Florianópolis: Editora Mulheres. Disponível em: http://historiacultural.mpbnet.com.br/feminismo/Joan_Scott-Experiencia.pdf

Spink, M. J., Menegon, V. M., \& Medrado, B. (2014). Oficinas como estratégia de pesquisa: articulações teórico-metodológicas e aplicações ético-políticas. Psicologia \& Sociedade, 26(1), 32-43. 
Vergueiro, V.(2016). Por inflexões decoloniais de corpos e identidades de gênero inconformes: uma análiseautoetnográfica da cisgeneridade como normatividade. (Dissertação de Mestrado, Universidade Federal da Bahia, Programa Multidisciplinar de Pós-Graduação em Cultura e Sociedade). Recuperado a partir de https://repositorio.ufba.br , ... > Dissertações de Mestrado (Poscultura)

World Professional Association for Transgender Health. (2012). Disponível em www.wpath.org/

Yogyakarta. Indonésia (2006). Princípios sobre a aplicação da legislação internacional de direitos humanos em relação à orientação sexual e identidade de gênero. Recuperado a partir de http://www.clam.org.br/uploads/conteudo/ principios_de_yogyakarta.pdf>

(Spink\& Medrado, 1999)

Sampaio J, Santos GC, Agostini M, Salvador AS, (2014).Limites e potencialidades das rodas de conversa no cuidado em saúde: COMUNICAÇÃO SAÚDE EDUCAÇÃO 2014; 18 Supl 2:1299-1312. www.scielo.br/pdf/icse/v18s2/1807-5762-icse-18s2-1299.pdf

Vasconcelos, T. M. (2015). Corpos em trânsitos, transes e tranças: produções de corporalidades por/com mulheres trans. (Dissertação de mestrado, Universidade Federal de Pernambuco, Programa de Pós-Graduação em Psicologia). Recuperado a partir de https://repositorio.ufpe.br/.../Thaissa\%20Machado\%20Vasconcelos_Dissertaçã o.pdf?...

Souza, É. Organizadora. Projeto transexualidades esaúde pública no brasil:entre a invisibilidade e a demandapor políticas públicaspara homens trans, Nucleo de Direitos Humanos, UFMG; 2015.

Ryckebusch, C. G. A "Roda de Conversa” na Educação Infantil:uma abordagem críticocolaborativa na produção de conhecimento [tese]. São Paulo: Pontifícia Universidade Católica de São Paulo; 2011. 


\section{CAPÍTULO X}

\section{DIÁLOGO FAMILIAR E SEXUALIDADE NA ADOLESCÊNCIA: CONTRIBUIÇÕES PARA A CONSTRUÇÃO DO EMPODERAMENTO FEMININO}

Bianca Valeska Marques da Silva ${ }^{1}$

${ }^{1}$ Graduanda do curso de Serviço Social. Universidade Federal da Paraíba - UFPB

\section{RESUMO}

Este artigo expõe abordagens que envolvem a situação da mulher no âmbito da sexualidade, cuja finalidade é discutir a contribuição do diálogo familiar, iniciado na adolescência, para a construção do empoderamento feminino, de modo que o julgamento de valor, o autoritarismo e a culpabilização não participem deste processo. Para tanto, realizou-se, além da pesquisa de revisão bibliográfica, uma pesquisa de caráter quantitativo e qualitativo, mediante a aplicação de questionário divulgado em meio eletrônico. Esta pesquisa alcançou diversas regiões do Brasil e teve a participação de 94 mulheres, as quais possuíam desde os 18 até acima dos 50 anos de idade. Por intermédio da coleta dos dados, constatou-se que raramente existe o diálogo sobre sexualidade no seio familiar direcionado às meninas adolescentes e que, quando existe, acontece de maneira superficial e insuficiente, em que fica restrito apenas às discussões biológicas. Neste sentido, através dos relatos das mulheres participantes do questionário, conclui-se que há uma predominância quanto à necessidade deste tipo de diálogo, de maneira que sejam abordadas concepções que ultrapassem a esfera biológica, o que torna possível a formação de uma sociedade onde as mulheres possam vincular as informações socializadas ao poder e, consequentemente, possam ser percebidas enquanto seres sociais que, além de possuírem sentimentos, também possuem desejos eróticos.

Palavras-chave: Sexualidade. Adolescência. Diálogo. Mulher. Empoderamento.

\section{INTRODUÇÃO}

O pensamento hegemônico misógino enxerga a mulher como um ser histórico passível de calar-se; ela foi ensinada por séculos a enxergar as suas aspirações como dignas de serem oprimidas. Nesta perspectiva, a mulher deve ser um ser sem voz, sem opinião e sem desejos; cabendo-lhe apenas a obediência do que deve ou não ser feito, como deve ser feito, por quem deve ser feito e quando deve ser feito. Como aponta Pinsky (2006, p. 11) na apresentação do livro Minha História das Mulheres, de Michelle Perrot, "no século XVIII ainda se discutia se as mulheres eram seres humanos como os 
homens ou se estavam mais próximas dos animais irracionais". Por este ângulo, é fácil perceber que as ações e os comportamentos masculinos eram - e ainda são - vistos com extrema superioridade, de maneira a reforçar os estereótipos e a dominação patriarcal acima da vontade feminina. Estes estereótipos, quando reforçados, supõem atos de agressividade, virilidade e inteligência aos homens, e às mulheres presumem fraqueza, submissão e dependência, ao passo que devem ignorar profundamente as suas vontades e os seus desejos.

A existência de uma cultura misógina de culpabilização e opressão às mulheres é ainda mais visível no campo da sexualidade. Desde a infância a menina "é impedida de pensar na própria vida sexual; induzida aos bons modos, tem suas perguntas ignoradas ou respondidas incompletamente; sempre que pensa em sexo, associa-o a algo errado e proibido." (GOZZO et al, 2000 apud MENEZES et al, 2011). No Brasil, este controle sexual fica mais evidente se levarmos em consideração a forte influência das perpetuações valorativas cristãs que, hegemonicamente, relacionam-se à defesa de um perfil de mulher que só pode ter relações sexuais depois do casamento; que, após o casamento, deve praticar o ato sexual apenas para reproduzir; que deve amar o seu marido fielmente e eternamente; e que deve amar estar grávida, haja vista que o/a filho/a é uma benção divina.

No âmbito familiar, é de extrema necessidade a prática de uma socialização e conscientização no que tange à sexualidade. A iniciativa pode partir dos entes mais próximos, através do diálogo, e direcioná-lo aos/às adolescentes, basta ver que a adolescência é um momento em que começam a se constituir mais nitidamente as visões de mundo e a percepção do próprio corpo.

Tendo por base estes apontamentos introdutórios, o estudo em tela pretende discutir a importância e a contribuição do diálogo, nas relações familiares, para a construção de conhecimento e de consciência sexual nas meninas adolescentes. Esta construção de saber e de consciência associa-se a um processo de empoderamento ${ }^{1}$, no sentido de que, a partir das informações adequadas, estas meninas podem conhecer os seus direitos e colocar as suas autonomias em prática, assim como as suas capacidades de assumir um maior controle sobre os seus próprios corpos.

\footnotetext{
${ }^{1}$ Momento em que o "saber é fortemente atrelado ao poder." (FAGUNDES, 2014, p. 7).
} 
Sendo assim, este trabalho, a partir da publicização de seus dados, colabora para a formação de uma sociedade que, por educação, compreende e respeita as mulheres enquanto indivíduos que também têm o direito de se dedicarem à sexualidade.

\section{METODOLOGIA}

Como já foi referido, o presente artigo objetiva abordar o essencial papel do diálogo familiar em relação à vida sexual e emocional de meninas adolescentes. Para a realização desta abordagem, além da pesquisa de revisão bibliográfica, optou-se por uma coleta de dados mediante a elaboração e aplicação de um questionário disponibilizado e divulgado em meio eletrônico. O questionário teve abrangência nacional e o público alvo foram, especificamente, mulheres que possuíam idade superior a 18 (dezoito) anos de idade. Tendo em vista que um dos focos desta pesquisa é analisar a fase da adolescência ${ }^{1}$, decidiu-se que o questionário seria respondido por mulheres que já passaram por esta fase, objetivando um compartilhamento mais amplo de experiências pessoais vividas na adolescência e, também, de opiniões em relação aos benefícios ou malefícios destas experiências, demarcando o que elas desejariam que fosse - ou não - modificado na época.

O questionário foi composto por oito questões, divididas entre perguntas objetivas de múltipla escolha e perguntas discursivas, conferindo, assim, uma pesquisa tanto quantitativa quanto qualitativa.

O questionário teve ampla divulgação online, através de redes sociais tais como o Facebook, o Messenger, o Whatsapp, o Instagram e o E-mail. As perguntas ficaram disponíveis em meio eletrônico entre os dias 24 e 29 de maio de 2019, totalizando 94 respostas.

Em seguida serão apresentados os dados coletados a partir da exibição de gráficos, resultantes das questões objetivas, e algumas respostas sistematizadas, resultantes das questões discursivas. Neste sentido, em total concordância com o sigilo absoluto - para que não haja identificação das participantes - os nomes não serão divulgados.

\footnotetext{
${ }^{1}$ Como consta no artigo 20 do Estatuto da Criança e do Adolescente (ECA), lei 8.069 de 1990, a adolescência compreende a faixa etária de 12 a 18 anos de idade.
} 


\section{DESENVOLVIMENTO}

A adolescência é um período de transição crucial na vida do ser humano; é o momento que possibilita a manifestação de múltiplas modificações, as quais percorrem um trajeto complexo, desde a maturação genital até a busca de uma nova identidade, tendo em vista que a identidade anterior (infantil) foi perdida. Neste sentido, como aponta Savegnago (2014), duas principais funções fisiológicas, advindas da puberdade ${ }^{1}$, amadurecem neste período: nas meninas é a chegada da menstruação e nos meninos é o aparecimento das glândulas seminais, que produzem o líquido seminal.

Este processo de transição da vida infantil para a vida adulta pode ser bastante confusa e dolorosa para os/as adolescentes, pois "é marcado por muitas [descobertas], contradições, ambivalências, e por atritos com a família e o meio social." (SEVEGNAGO, 2014, p. 24). Por este ângulo, é de suma importância a presença e participação das figuras paternas e/ou maternas, em especial no que diz respeito ao acolhimento do/a adolescente em momentos de desespero decorrentes de uma possível crise existencial ou sensação de não pertencimento à determinado grupo social; além, é claro, do esforço pela busca de respostas àqueles inevitáveis questionamentos curiosos acerca da sexualidade. Ademais, é necessário considerar que a família não está isenta do sofrimento que este período vital pode provocar, haja vista que os "dois lados da moeda" estão transcorrendo transformações psicológicas e passam a indagar sobre a própria existência. No caso dos pais e das mães, dependendo de como se deu o período de descobertas e curiosidades, haverá uma extrema dificuldade para repassar conselhos e respostas adequadas às dúvidas dos seus filhos/as. Nesta mesma linha de raciocínio, Sevegnago (2014) contribui na argumentação quando afirma que "os pais podem angustiar-se neste período principalmente em decorrência das evocações conscientes e inconscientes de suas fantasias e de comportamentos presentes em sua própria adolescência." (SEVEGNAGO, 2014, p. 27).

Ao longo deste trabalho o termo "sexualidade" foi bastante utilizado, porém é preciso retomá-lo brevemente para destrinchar sua definição. Existem inúmeros estudos que abordam a sexualidade, mas poucos informam o que, de fato, significa este

${ }^{1}$ A puberdade marca o início da adolescência, pois "refere-se às manifestações físicas do amadurecimento sexual." (SAVEGNAGO, 2014, p. 23). 
conceito, pois, no senso comum, ele é resumido à relação sexual e genitalidade. Acerca disso, a colocação realizada por Louro (2007) é bastante pertinente quando afirma que

Embora o corpo biológico seja o local da sexualidade, estabalecendo os limites daquilo que é sexualmente possível, a sexualidade é mais do que simplesmente o corpo. De fato, juntamente com Carole Vance (1984), estou sugerindo que o órgão mais importante nos humanos é aquele que está entre as orelhas. A sexualidade tem tanto a ver com nossas crenças, ideologias e imaginações quanto com nosso corpo físico. (LOURO, 2007, p. 38).

Neste sentido, se partirmos da citação apresentada acima ou de uma análise psicanalítica Freudiana ${ }^{1}$, percebemos que vários outros fenômenos estão envolvidos no campo da sexualidade, como as relações sociais e psíquicas dos indivíduos (BEARZOTI, 1993). Sendo assim, é certo dizer que as reflexões e abstrações referentes ao corpo, ao prazer e à afetividade, e os fatores socioculturais também fazem parte da sexualidade. Isto é, este fenômeno (a sexualidade) abarca diversas características subjetivas pessoais -, físicas e mentais do ser social ${ }^{2}$, não se limitando aos órgãos sexuais ou ao ato sexual propriamente dito.

\section{RESULTADOS E DISCUSSÃO}

Das 94 mulheres que participaram do questionário divulgado em meio eletrônico, houve a predominância da faixa etária entre 18 e 22 anos, o que correspondeu a um total de $62,8 \%$, porém diversas outras idades foram registradas, chegando a atingir, inclusive, mulheres com idade superior a 50 anos.

${ }^{1}$ Freud prefere falar psicossexualidade, pois vai além da reprodução. (BEARZOTI, 1993).

${ }^{2}$ Baseando-se em Marx, "O indivíduo é o ser social. Sua manifestação de vida - mesmo que ela também não pareça na forma imediata de uma manifestação comunitária de vida, realizada simultaneamente com outros - é, por isso, uma externação e confirmação da vida social". (MARX, 2004, p. 107). 
Gráfico 1 - Faixa etária das participantes
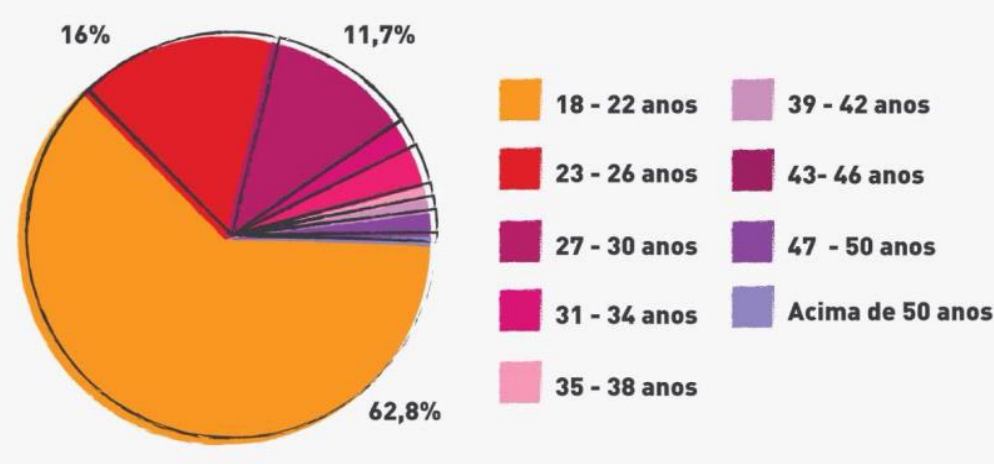

Fonte: Autoria própria.

Quanto a regionalidade, as mulheres nordestinas apresentaram a maior quantidade de respostas ao questionário, com $37,2 \%$. A pesquisa tem o seu segundo maior alcance nas mulheres do Sudeste, apresentando $34,8 \%$, entretanto o estudo também foi contemplado pelas regiões Sul, Centro Oeste e Norte, com menores porcentagens.

\section{Gráfico 2 - Regionalidade das participantes}

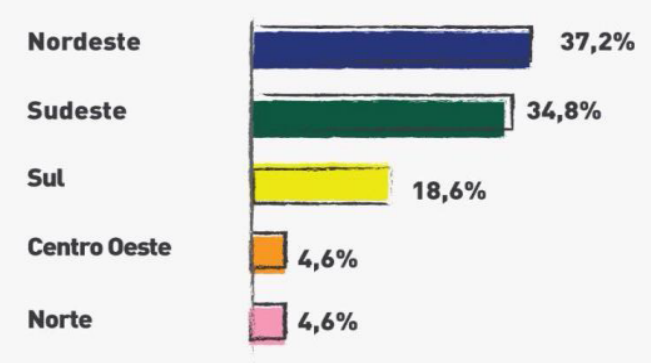

Fonte: Autoria própria.

Por conseguinte, na pesquisa foi questionado se, na fase da adolescência, estas mulheres tinham uma abertura para dialogar sobre sexualidade com as suas figuras maternas e/ou paternas ${ }^{1}$. Mais da metade alegou que não tiveram, sendo possível visualizar o resultado no gráfico 3:

${ }^{1}$ Utilizei este termo pelo fato de não querer restringir a responsabilidade apenas para os pais e para as mães das adolescentes. Os avós, por exemplo, têm extrema importância neste momento, mesmo sabendo que o diálogo tende a ser mais difícil por se tratar de épocas diferentes e longínquas. Fora isso, empreguei o termo para não limitar aos arranjos familiares que estão dentro dos padrões de heteronormatividade. 
Gráfico 3 - Abertura das participantes no diálogo sobre sexualidade com a família

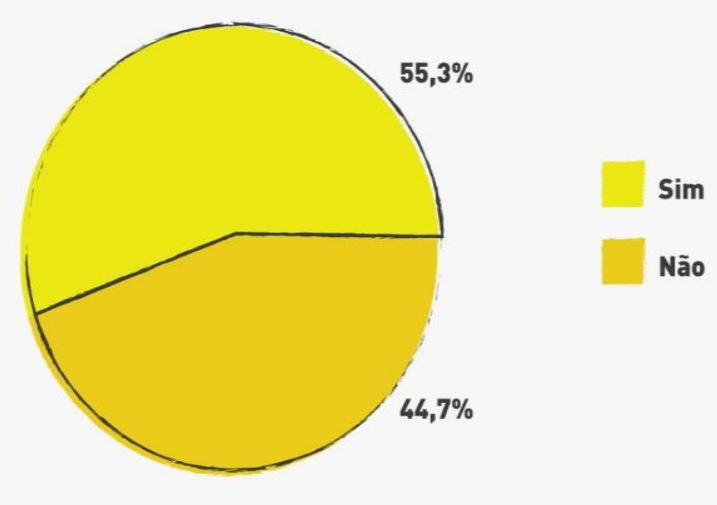

Fonte: Autoria própria.

Além disso, para as mulheres que responderam "sim" a esta pergunta, foi indagado quais assuntos foram dialogados com as suas figuras maternas e/ou paternas. Diante das respostas, constatou-se que 95,6\% dialogaram sobre mudanças corporais, em que a menstruação, o aumento dos seios e o aumento da libido foram apresentados no questionário como exemplos desta temática; $57,8 \%$ já dialogaram sobre vida emocional (sentimentos) e sobre promoção da saúde sexual e Doenças Sexualmente Transmissíveis (DST's) - como exemplos do diálogo sobre saúde foram apresentados o uso de preservativos, o uso de contraceptivos e a higienização íntima adequada. O diálogo sobre iniciação sexual aparece em uma porcentagem bastante inferior $(31,1 \%)$, em que a perda da virgindade, a masturbação e o orgasmo foram expostos como exemplos, no momento da indagação. Outros assuntos dialogados aparecem com 2,2\%; nesta opção, as mulheres ficaram livres para acrescentar algum assunto que já foi dialogado, mas que não constou no questionário. Foram acrescentados os diálogos sobre orientação sexual e violência sexual. 
Gráfico 4 - Assuntos dialogados com a família das participantes sobre sexualidade

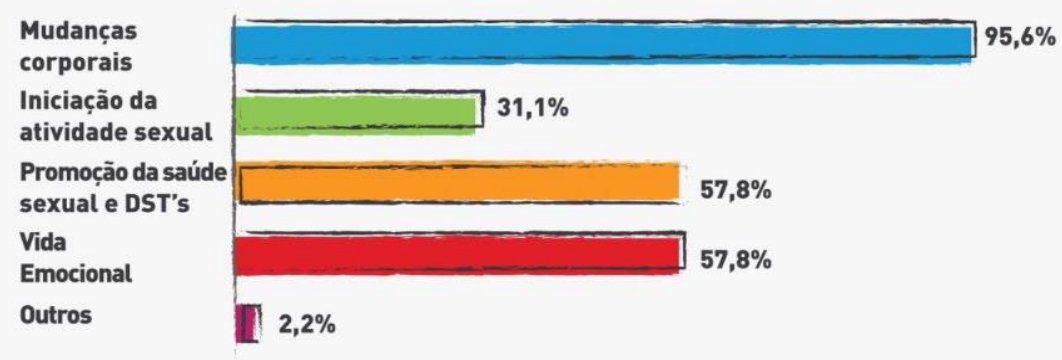

Fonte: Autoria própria.

Para mais, ainda focando a pergunta para as mulheres que afirmaram ter tido abertura quanto ao diálogo sobre sexualidade com a família, questionou-se se esta abertura, na visão delas, foi algo positivo ou negativo, e por qual motivo. Acerca disso, 92,7\% destacaram ter sido positivo, 2,5\% declararam como indiferente, 2,5\% consideraram tanto positivo quanto negativo e $2,5 \%$ apenas como negativo, o que confirma a predominância da positividade do diálogo.

Neste sentido, como nos apontou a mulher 4, este tipo de abertura prepara a jovem para os desafios futuros referentes à sexualidade: "Foi positivo, mesmo essa abertura sendo bem pouca, me preparou para enfrentamentos futuros com relação ao desenvolvimento do meu corpo, assédios e inseguranças". Opiniões semelhantes a esta são compartilhadas por outras participantes, como pode ser observada na resposta da mulher 7:

Foi positivo, pois conversar sobre as mudanças do corpo feminino nos prepara para o que está por vir e ainda ensina que não podemos deixar qualquer um ver ou mexer nas nossas partes, visto que temos um grande número de meninas que já foram violadas. (Mulher 7).

Como citado anteriormente, apenas uma pequena parcela das mulheres considerou esta prática entre as adolescentes e os seus/suas responsáveis como algo negativo. A mulher 40 assim a considerou, quando expôs que "poderia ter sido acolhida e ter feito escolhas melhores na vida"; porém, até mesmo neste caso, percebe-se que o fator negativo não está, literalmente, na existência do diálogo, mas na forma como ele 
se coloca, em que mesmo existindo não há acolhimento e nem preparo em relação ao enfrentamento de futuras decisões.

Ademais, às mulheres que declararam não ter tido nenhum tipo de abertura no tocante ao diálogo sobre sexualidade com as figuras familiares, foi questionado se elas gostariam de ter tido esta abertura, e por qual motivo. A partir da coleta dos dados, constatou-se que 95,7\% das mulheres teriam gostado de uma abertura nos diálogos familiares na adolescência, enquanto que 4,3\% declararam que não gostariam e que não acharam necessário.

Nesta perspectiva, a mulher 12 trouxe diversos elementos em sua resposta, desde a orientação sexual até a influência familiar cristã e sentimentos de medo e culpa:

Eu gostaria. Sou LGBT e cresci numa casa de pessoas muito católicas, então senti muita falta de alguém com que eu pudesse falar sobre a culpa cristã que eu sentia por estar sentindo atração por meninas. Quando eu era novinha minha avó leu em um dos meus cadernos que eu tava gostando de uma menina da escola e depois de algumas indiretas nunca mais tocaram no assunto e até hoje não consegui me assumir completamente por medo. Sabem mas fingem que não sabem e ficamos arrodeando o assunto quando falamos de algo que tem a ver com homossexualidade. Ainda é muito confuso pra mim se devia falar, como falar, se mudaria algo, etc. Até porquê ainda tenho dúvidas e dificuldades com a minha própria sexualidade e não sei como abordaria esse assunto com minha família. (Mulher 12).

Aprofundando este pensamento, a mulher 44 declarou o seguinte:

\begin{abstract}
"Apesar de minha mãe sempre me mostrar o caminho e o acesso a informação, eu gostaria de ter dialogado mais abertamente com ela sobre essas questões, acredito que se tivesse eu não tinha passado metade dos perrengues que passei na adolescência. Hoje eu tenho uma filha e esse diálogo será não só aberto como escancarado entre nós. Acredito que esse acolhimento e informações vindo do seio familiar com entendimento e sem tabus é fundamental para formação e empoderamento das nossas futuras mulheres". (Mulher 44).
\end{abstract}

Na contramão destas opiniões, a mulher 23 apontou não achar necessário, pois “apesar de não ter havido o diálogo, sempre tive acesso a leituras diversificadas, inclusive educação sexual". 
A mulher 43 afirmou que "não, pois iria ser desconfortável se acontecesse 0 diálogo". É necessário refletirmos sobre esta resposta no sentido de que o desconforto, nestas situações, só acontece se o assunto não for tratado com naturalidade e transparência desde cedo. Caso os julgamentos de valor sobressaiam o companheiris mo e o esforço de compreensão e apoio entre os/as responsáveis e as meninas adolescentes, realmente o desconforto e a timidez prevalecerão.

Com base nestes apontamentos e a fim de discutir estes aspectos, nota-se pelas respostas das mulheres participantes do questionário online que, muitas vezes, nos diálogos sobre sexualidade, acontecem apenas abordagens acerca de mudanças corporais, vida emocional e DST's, de modo a confirmar a existência de diversas privações no seio familiar, norteadas pelo controle sobre os corpos das meninas e pelo autoritarismo. Neste sentido, percebe-se que os parentes evitam conversar diretamente sobre sexo perda de virgindade, masturbação e orgasmo -, seja por timidez ou pela perpetuação de pensamentos como: se tais assuntos forem abordados, haverá o incentivo e a influência quanto a estas práticas. Logo, como defende Louro (2007),

Redobra-se ou renova-se a vigilância sobre a sexualidade, mas essa vigiância não sufoca a curiosidade e o interesse, conseguindo, apenas, limitar sua manifestação desembaraçada e sua expressão franca. As perguntas, fantasias, as dúvidas e a experimentação do prazer são remetidas ao segredo e ao privado. Através de múltipas estratégias de disciplinamento, aprendemos a vergonha e a culpa; experimentamos a censura e o controle. (LOURO, 2007, p. 27).

Ainda sobre isso, Nery et al (2015), de certa forma, complementa a defesa presente na citação exposta acima e afirma que "quando os jovens não obtêm respostas para suas questões no lar, eles costumam busca-las com terceiros, amigos da mesma faixa etária, parceiros ou mesmo na mídia, que são elementos que repassam informações incompletas ou imprecisas" (NERY et al, 2015, p. 290). Em outras palavras: a sexualidade é disciplinada e censurada, destinando o diálogo aberto e livre ao âmbito privado, entretanto as adolescentes não deixam de ir atrás de respostas para as suas curiosidades apenas pelo fato de não terem sido abordadas em casa; ao contrário, buscarão em fontes não tão confiáveis quanto a família, o que pode trazer consequências extremamente preocupantes. 


\section{CONSIDERAÇÕES FINAIS}

Com base nos pressupostos discutidos, conclui-se que existem dificuldades referentes ao diálogo familiar voltado para as meninas adolescentes acerca da sexualidade. Raramente acontece o diálogo, porém, quando acontece, não há a contemplação de toda a temática, a qual, muitas vezes, fica restrita apenas às orientações sobre DST's ou gravidez não planejada.

Para que o processo de empoderamento das mulheres - relacionado à sexualidade - seja efetivado, é necessário que as figuras maternas e/ou paternas se interessem em compreender as particularidades históricas das vivências de mulheres e da adolescência, e destas duas atreladas ao âmbito da sexualidade - extrapolando os debates biológicos. Após o entendimento destes fenômenos, é preciso que as famílias estejam dispostas a acolherem as dúvidas, curiosidades e desabafos das adolescentes, orientando-as de maneira natural e honesta, sem reprimi-las ou culpa-las. Neste sentido, através das instruções adequadas, em uma perspectiva de construção de empoderamento, as adolescentes poderão compreender corretamente, a partir de fontes confiáveis, os reais benefícios ou malefícios de elementos referentes à sexualidade, e poderão tomar decisões futuras de maneira consciente. Além disso, a percepção de possíveis desrespeitos, assédios ou violações contra os seus corpos serão mais rapidamente observadas e, consequentemente, mais rapidamente tomadas as providências cabíveis.

\section{REFERÊNCIAS}

BEARZOTI, P. Sexualidade: um conceito psicanalítico freudiano. Arq. Neuro-Psiquiatr., São Paulo, v. 52, n.1, p. 1-5, mar. 1994. Disponível em: <encurtador.com.br/kHOQ2>. Acesso em: 21 jul. 2019.

BRASIL. Lei № 8.069, de 13 de julho de 1990. Dispõe sobre o Estatuto da Criança e do Adolescente e dá outras providências. Diário Oficial da União, Brasília, DF, 16 jul. 1990. Disponível em: <encurtador.com.br/inLPS>. Acesso em: 02 jul. 2019.

FAGUNDES, T. C. P. C. Sexualidade, gênero e poder - educação numa perspectiva emancipatória. Salvador; Revista Espaço Acadêmico; 2014. Disponível em: <encurtador.com.br/jlEY9>. Acesso em: 11 jul. 2019. 
LOURO, G. L. O corpo educado: pedagogias da sexualidade: 2. ed. Belo Horizonte: Autêntica, 2007.

MARX, K. Manuscritos econômico-filosóficos: 1. ed. São Paulo: Boitempo Editorial, 2004.

MENEZES, K. R. L.; MACHADO, A. G.; GALVÃO, A. L. V.; CORDEIRO, M. A. C. P.; SILVEIRA, M. T. Sexualidade Feminina: como séculos de cultura opressiva ainda influenciam o imaginário feminino. In: IX Mostra de Extensão e Cultura, 2011, Goiás. Anais... Goiás: Universidade Federal de Goiás. Disponível em: <encurtador.com.br/wPR39>. Acesso em: 11 jul. 2019.

NERY, I. S.; FEITOSA, J. J. M.; SOUSA, A. F. L.; FERNANDES, A. C. N. Abordagem da sexualidade no diálogo entre pais e adolescentes. São Paulo; Acta Paulista de Enfermagem; 2015. Disponível em: <encurtador.com.br/hqsAF >. Acesso em: 03 jul. 2019.

PERROT, M. Minha história das mulheres: 1. ed. São Paulo: Contexto, 2007.

SAVEGNAGO, S. D. O. Conversando sobre sexualidade com filhos adolescentes: o olhar de mães de grupos populares. 2014. 208f. Dissertação (Mestrado em Psicologia) - Universidade Federal de Santa Maria, Rio Grande do Sul. Disponível em: <encurtador.com.br/bqux4>. Acesso em: 11 jul. 2019. 


\title{
CAPÍTULO XI
}

\section{DIREITO À IDENTIDADE, PERSONALIDADE E DIGNIDADE DAS PESSOAS TRANSEXUAIS NO BRASIL - NOME E SEXO/GÊNERO COMO DIREITOS CONSTITUCIONAIS E CIVIS}

Kelly Alves de Souza ${ }^{1}$

\begin{abstract}
${ }^{1}$ Graduada em Serviço Social. Universidade Paulista (UNIP). Pós-Graduanda em Serviço Social e Gestão de Políticas Públicas (CISCE - Centro Integrado e Serviços e Consultoria Educacional) - polo FACSU; Campina Grande - PB. PósGraduanda em Docência e Gestão do Ensino Superior - UNINASSAU; Campina Grande - PB.
\end{abstract}

\section{RESUMO}

O artigo apresentado vem discutir a Transexualidade e seus aspectos políticos, sociais, históricos e culturais acerca dessas experiências e vivências na sociedade no contexto Brasil e seus reflexos no legislativo em âmbito nacional. Neste trabalho discute-se acerca da inconstitucionalidade proposta no PL 2.578/2020 protocolado na Câmara Federal pelo deputado federal Felipe Barros - PSL Paraná, onde o mesmo determina que os corpos e identidades - gêneros têm como definidores e legitimadores as características sexuais primárias, ou seja, (homem - pênis; mulher - vagina), além de defender questões biológicas e cromossomáticas. As discussões aqui pautadas não se esgotam neste trabalho tendo em vista a dimensão e riqueza acerca dessa problemática. No que tange às mulheres Trans, Transexuais, Travestis e homens Trans; Projetos de Lei com esse tipo de proposta corroboram para exclusões, preconceitos, discriminações e o não reconhecimento do ser humano, além de ferir claramente princípios constitucionais dispostos na Constituição Federal de 1988. Faz-se necessário reconhecer o gênero enquanto uma construção social, cultural, histórica e política. O PL em questão claramente afronta a decisão do Ministro Edson Fachin no que se refere à decisão da ADI $n^{\circ} 4.275$, em que a mesma garante o direito às pessoas Transexuais solicitarem as alterações de prenome e gênero nos documentos junto aos cartórios de todo o país e que se façam nos demais termos de registros.

Palavras-chave: PL. Identidades. Transexualidade. Gênero. ADI 4.275.

\section{INTRODUÇÃO}

O uso do nome em consonância com o gênero é uma maneira de garantir o exercício pleno da cidadania em se tratando de mulheres Transexuais, Travestis e homens Trans.

As discussões discorridas neste trabalho se pautam em refutar as declarações propostas no PL 2.578 de autoria do deputado federal Felipe Barros - PSL Paraná protocolado junto a câmara dos deputados. 
O referido Projeto de Lei em que discorre sobre o reconhecimento do gênero tendo por base questões únicas e exclusivamente regidas nas características primárias - cromossomáticas e biológicas para se definir o que seria "homem" ou "mulher" perante o reconhecimento do Estado brasileiro. Bento (2006-2012) defende que a única verdade do gênero é a prática -, materialização e personificação, ou seja, gênero nada tem a ver com biologia ou cromossomos (XX, fêmea - feminino -, mulher ou XY, macho - masculino -, homem) como defendido no referido PL expressando sua inconstitucionalidade e este tendo sido proposto pelo deputado em questão.

Butler (2017) assegura que os corpos que são inteligíveis para a norma binária imposta social, política, histórica e culturalmente são os gêneros conformes, ou seja, são aqueles que reconhecem-se e percebem-se como designados no nascimento homem pênis -, masculino ou mulher - vagina -, feminino. Desse modo, as identidades e os corpos trans rompem com essa normatização e cristalização imposta aos corpos sexuados e genitalizados. Em sendo assim, estão à margem do reconhecimento social e político no que se refere às suas identidades e corpos.

Portanto, esses discursos políticos e de cunho conerservador e normatizador demonstram claramente posições discriminatórias, excludentes, preconceituosas, sexistas e binárias defendidos pelo PL 2.578/2020.

Isto posto, discussões como as defendidas pelo deputado em questão, além de extremamente sexista, machista, misógina, Transfóbica e excludente alijam corpos e identidades que vivem no limbo das relações sociais de maneira alarmante. "Como fica claro o discurso analisado neste estudo é inequivocamente intolerante e preconceituoso, como tantos outros". Caputo (2017, p. 94).

O mesmo documento -, PL vai de encontro - viola a ADI 4.275, e a decisão tomada pelo ministro Edson Fachin do Supremo Tribunal Federal - STF, onde garante que pessoas Trans - Transexuais; (mulheres trans, travestis e homens trans) possam requerer a alteração no assento de nascimento e nos demais termos de registros em cartórios de todo o país sem que haja a necessidade de laudos médicos que venham a "comprovar" à transexualidade.

Dessa maneira, prevalece o entendimento do ministro de que o gênero não mais pode ser entendido única e exclusivamente como uma categoria diagnóstica, ou seja, compreende-o como um construto social perpassado por questões e análises históricas, 
políticas e culturais. Ademais, não mais havendo a necessidade de processos judiciais para requerer tal direito, entendendo e respeitando os princípios da personalidade, intimidade e dignidade da pessoa humana, estes como garantias constitucionais fundamentais e invioláveis. "A constituição Federal do Brasil assegura em seu Título I Princípios e Garantias Fundamentais, art. $1^{\circ}$ inc. II e III, bem como no art. $3^{\circ}$ inc. IV e art. $4^{\circ}$ inc. II".

No que se refere aos direitos inerentes à pessoa humana previstos na Carta Magna de 1988, bem como na Declaração Universal dos Direitos Humanos de 1948, analisa-se na proposta em relação ao PL 2.578/2020 protocolada na Câmara Federal pelo deputado federal Felipe Barros com filiação ao antigo partido do atual presidente - PSL, claramente demonstra que determinados parlamentares em vez de legislar em prol do bem de todo conjunto da sociedade e mais especificamente neste momento em que vive-se a pandemia - COVID-19 restringem-se à debates que claramente afrontam os princípios constitucionais e estes como sendo invioláveis ante o exposto na Constituição Federal do Brasil de 1988.

Segundo Santos, Chaui (2018) asseveram que a opressão sempre será um produto de imposição nas relações de poder, ou seja, entendendo que o Estado se encontra em uma relação de força no que tange à sociedade e com isso, os cidadãos e cidadãs insurgem dessa e nessa relação de poder e imposição. Dito isto, entendemos que o Estado sob quaisquer hipóteses pode legislar no sentido de onerar os seus legislados e legisladas.

De tal modo, ao passo em que no Brasil não se tem uma lei especifica que venha proteger e garantir os direitos que concernem às pessoas Trans, fica claro as negações em se tratando dessas identidades e corpos na sociedade.

Segundo Ventura (2010) há uma regulação em relação à pessoa transexual; (regulação de maneira negativa, pontuo aqui). Destarte, em se tratando dos direitos para a população Trans, observa-se que não há o exercício pleno da cidadania e o Estado precisa se posicionar frente à essas questões e dar garantias para que pessoas transexuais sejam reconhecidas como seres políticos e que demandam um série de intervenções que venham a minorar - sanar todas as formas de discriminação, imposição, preconceito e subordinação das quais mulheres transexuais, travestis e homens Trans estão sendo submetidas e submetidos rotineiramente. 
"O que se observa é uma prática continua de controle e regulação do corpo social e individual, e a adoção de uma perspectiva conservadora e biologizante, notadamente no campo das políticas públicas, [...]”, (VENTURA, 2010, p. 31).

\section{DESENVOLVIMENTO}

Em se tratando do PL 2.578/2020 protocolado na Câmara Federal pelo então deputado Federal com filiação ao PSL - PR Felipe Barros, onde o mesmo solicita a referida casa legislativa que se faça reconhecer o gênero apenas e tão somente enquanto condição - construção biológica, ou seja, colocando identidades e corpos dissidentes à margem da sociedade e promovendo mais exclusão, discriminação e preconceitos - Transfobias.

As concepções de gênero - desenvolvidas no Brasil e no mundo a partir das décadas de 1980, 1990, 2000, 2010 e que seguem neste decênio a partir da visão de feministas e teóricas pós estruturalistas como a Filósofa estadunidense e professora do departamento de Retórica e Literatura comparada da Universidade da Califórnia em Berkeley; Judith Butler, a australiana Raewyn Connell - Socióloga - professora e pesquisadora na Universidade de Sidney - Austrália; Berenice Bento - Socióloga professora do departamento de Sociologia da Universidade de Brasília - Brasil, além de outras autoras que discutem essa problemática no contexto Brasil, bem como internacional.

Essas teóricas refutam - discordam sobre as discussões e percepções de gênero enquanto uma construção puramente biológica - comossomática -, corpos sexuados e genitalizados -, essencializando-os e estabilizando-os.

Para as autoras acima referenciadas, gênero é uma construção social e perpassa questões como por exemplo, históricas, políticas e culturais. Esses fatores estão associados intrinsecamente na formação do gênero. As concepções perpetradas pelo referido parlamentar mostra-se bastante conservadora, sexista, machista, Transfóbica e patriarcal. O Estado precisa se colocar frente às demandas postas por essa população que é legítima.

O citado PL declaradamente afronta a decisão do ministro do STF Edson Fachin no que se refere à decisão e, por conseguinte, aprovação da $A D I$ de $n^{\circ} 4.275$, em que a mesma reconhece o direito das pessoas transexuais terem em seu assento de 
nascimento e nos demais termos de registro nome e sexo/gênero em conformidade a sua identidade de gênero, esta última entendida como um construto social, histórico, político e cultural.

A interpretação que apresento da experiência transexual e a relação que se estabelece com o poder/saber médico estão ancoradas no estudos queer. Essa perspectiva teórica argumentará que a dicotomia natureza (corpo) versus cultura (gênero) Não tem sentido, pois não existe um corpo anterior a cultura, ao contrário, ele é fabricado por tecnologias precisas. O corpo sexuado (o corpo-homem e o corpomulher) que dá inteligibilidade aos gêneros, encontra na experiência transexual os seus próprios limites discursivos, uma vez que aqui o gênero significará o corpo, revertendo assim um dos pilares de sustentação das normas de gênero. (BENTO, 2017, p. 17).

Para as autoras acima referenciadas o gênero perpassa as questões biológicas e cromossomáticas, tese defendida pelo deputado em questão. Deste modo, para a autora Bento (2006) a única verdade do gênero é a prática, não existe uma essência inata para conferir inteligibilidade às identidades e corpos como defende Butler (2017). Com isso, entende-se que a formação e construção do gênero precisa ser compreendida para além das questões "biofisiomorfológicas". Destarte, o gênero enquanto uma categoria de análise, necessariamente deve-se considerar questões referentes a fatores sociais, culturais, históricos e políticos. Segundo Ventura:

"Sexo, gênero e sexualidade são conceitos que envolvem amplas discussões e pouco consenso sobre sua compreensão nos diversos campos do saber, admitindo significados distintos e diversos, até mesmo do ponto de vista semântico. Ventura (2010, p. 19).

Grosso modo, a lógica de gênero baseada única e exclusivamente pela biologia e cromossomos não se sustenta. As identidades e os corpos Trans estão aí e provando que são legítimas e legítimos nas sociedades - corpos e identidades concretos, ou seja, não se defende uma abstração nos discursos aqui pautados, defende-se seres políticos e socais que lutam pelo reconhecimento de suas identidades e dos direitos inerentes aos cidadãos e cidadãs na sociedade brasileira. "A construção da identidade de gênero é um processo de longa e ininterrupta duração". Bento (2017, p. 92). 
Assim sendo, corroborando com os assuntos acima afirmados de que o gênero é um construto social, cultual, político e histórico, faz-se imprescindível reconhecer que à população Trans (Mulheres Trans, Transexuais, Travestis e Homens Trans) no cenário brasileiro está alijada dos direitos que são inerentemente constituídos para conferir proteção, defesa e reconhecimento dos seres humanos enquanto sujeitos de direito constituído. O PL em questão viola Direitos Constitucionais dispostos no Título I Dos Princípios Fundamentais; art. $1^{\circ}$ e seus respectivos Inc. II e III, art. $3^{\circ}$, em seu inc. IV e art. $4^{\circ}$ inc. II; Título II Dos Direitos e Garantias Constitucionais, bem como em seu capítulo I e art. $5^{\circ}$ inc. I.

O princípio da dignidade da pessoa humana serve para ser tratado e aplicado no campo da Bioética e do Direito, tendo em vista que o estudo e a prática são interdisciplinares, abrangendo a qualidade de vida, a licitude e a eticidade. (CASTRO, 2016, P. 28).

Ao passo em que a pessoa tem o direito de expressar livremente à sua identidade e esta sem sofrer quaisquer coações por parte da sociedade, bem como do Estado e instituições públicas e privadas é dever dos cidadãos e cidadãs e obrigação do Estado enquanto regulador das relações sociais assegurar esses direitos. As identidades e os corpos Trans são legítimos e se legitimam em sua construção e representação na sociedade e o Estado brasileiro enquanto ente regulador dessas relações substancialmente obriga-se a garantir que os princípios constitucionais e estes como invioláveis possam se efetivar na prática. Sendo assim, uma vida justa, sem violências e violações é um direito da população Trans ora em questão, da mesma forma todas as identidades e corpos que vivem no limbo das relações sociais e políticas de modo geral.

[...], os maiores problemas na vida das mulheres transexuais, particularmente problemas sociais, não são bem representados pelos discursos identitários de nenhum tipo. Esses problemas incluem a natureza da transição, o corpo transexual no trabalho, as relações no ambiente de trabalho, pobreza, o funcionamento das organizações estatais incluindo a polícia, política de saúde, serviços familiares, educação e assistência infantil. Connell (2016, p. 235).

O Nome e o gênero em consonância a identidade construída, vivida, representada e experienciada na sociedade, garantem que princípios como o da 
cidadania seja efetivado na prática, assim como os direitos à intimidade, personalidade e dignidade da pessoa humana, estes como basilares da nossa Constituição Federal de 1988 - Constituição Cidadã.

Gonçalves (2014) defende que se perpetrem as mudanças de nome e sexo gênero no assento de nascimento e nos demais termos de registros para que se façam efetivar na prática os direitos e garantias constitucionais, com o intuito de assegurar a correspondência entre a identidade de gênero e a identidade jurídica da pessoa, no caso aqui em discussão as identidades Trans -, (Mulheres Trans, Transexuais e Homens Trans).

A adequação do nome e do sexo civil ao sentir, agir e aparentar que se completam na identidade de alguém que foi percebida como singela, senão para evitar, ao menos para diminuir o constrangimento e a discriminação experimentadas pelos transexuais por ocasião de sua identificação perante a sociedade. (GONÇALVES, 2014, p. 22).

Ou seja, Mulheres Transexuais e Homens Transexuais ao passo em que se apresentam e representam socialmente e tendo rompido com as normas binárias e cisnormativas impostas as identidades hegemônicas demandam uma série de necessidades e o Estado enquanto garantidor de direitos precisa se posicionar frente à essas necessidades - demandas e efetivá-las para que se faça valer o exercício pleno da cidadania.

\section{RESULTADOS E DISCUSSÕES}

Os padrões hegemônicos instituídos ao longo da história não podem ser usados como regra, uma vez que ao longo dos séculos as sociedades, as pessoas, identidades e corpos e as sexualidades vão se reconfigurando e modificando tornando-se legitimas e se legitimando-se em suas experiências e vivências diárias na sociedade. Usar de preconceito e de padrões arcaicos para definir o que é ser "homem" ou "mulher" é incitar ódio e intolerância e expropriar os seres humanos de sua humanidade. Para Castro (2016, p. 44).

As diferenças biológicas entre os copos não determinam o comportamento social das pessoas nem sua performatividade. 0 
gênero e o desejo não estão na aparência dos genitais, fato já largamente comprovado pelas pessoas transgêneras e transexuais. 0 silencio e a indiferença desconstroem o discurso o discurso dos Direitos Humanos e comprometem o exercício desse direitos.

No que tange aos Direitos que são intrínsecos aos seres humanos, observa-se que comumente estão sendo negados e/ou negligenciados quando se tratam de mulheres transexuais e homens trans no Brasil. Assim sendo, o sexo biológico anatômico genital não pode ser o único definidor da identidade para conferir inteligibilidade ao ser "homem" ou "mulher" e como defendido anteriormente, os fatores sociais, culturais, históricos e políticos devem ser levados em consideração na formação, materialização, personificação e representação do gênero.

Diante de todas as explanações acerca da transexualidade - identidades de gênero aqui postas e em relação ao PL 2.578/2020 de autoria do deputado federal Felipe Barros - PSL, Paraná cujo teor fere princípios defendidos na Constituição Federal de 1988, entre esses, o da personalidade, dignidade da pessoa da humana, além da inviolabilidade do direito e o exercício da cidadania. "Os direitos humanos fundamentais são aqueles previstos nas constituições dos países, tendo por base a dignidade das pessoas humanas", [...]. Castro (2016, p. 51), com isso, faz-se necessário o imediato arquivamento do mesmo por ser notório sua inconstitucionalidade.

Dessa maneira, no que se refere às identidades Trans tem-se como análise que esses direitos mesmo sendo essenciais aos seres humanos estão longe de se efetivarem no que tange à proteção e defesa dessas população diante de todas as suas demandas e necessidades postas pela sociedade e pelas Políticas Públicas e Sociais excludentes e Transfóbicas que a todo instante tenta se sobressair e empurrar para às margens quem já está nas margens.

Embora todas as pessoas cuja identidade social real, em alguma medida, não corresponda ao estereótipo descrito sofram as consequências de serem estigmatizadas, isso não ocorre da mesma maneira com todas elas. Caputo (2017, p. 59).

Ou seja, mesmo as pessoas que são discriminadas por outros marcadores sociais, pode-se analisar que mulheres transexuais sofrem com potencialidade esses estigmas, uma das mais cruéis provas dessas discriminações é provada a medida em que se tem 
90\% dessa população vivendo exclusivamente da prostituição compulsória, como apontado por Nogueira e Benevides (2019).

Essas mulheres não conseguem ter ou manter-se no seio familiar, bem como a negação por parte do Estado ao passo em que não se têm Políticas Públicas formuladas e implementadas que venham a sanar e/ou até mesmo minorar os infortúnios -, entraves impostos a essa população.

As mudanças de nome e sexo/gênero nos documentos servem de medida de proteção e defesa dos direitos constitucionais como os da personalidade, cidadania e dignidade da pessoa humana. "A hegemonia dos direitos humanos como linguagem de dignidade humana é hoje incontestável". Santos, Chaui (2018, p. 42).

Caputo (2017) assegura que além do reconhecimento constitucional conferido aos cidadãs e cidadãs no Brasil, faz-se imprescindível e de extrema importância que todos os ambientes sociais - instituições públicas - empresas e estatais estejam preparadas para lidarem com as questões referentes ao gênero e identidades de gênero - mulheres Trans, Transexuais, Travestis e homens Trans.

Sendo assim, defende-se em muitos casos o uso do nome social, mas reforço que este último não garante o exercício pleno da cidadania - pois expõe as pessoas componentes deste grupo que social e historicamente sofrem com todas as subordinações, estigmas, marginalizações e opressões relacionados à Transexualidade enquanto materialização e personificação do gênero na sociedade ao passo em que rompem com as normas binárias e sexistas impostas para conferir inteligibilidade legitimidade aos corpos - identidades.

Sendo assim e com a aprovação da ADI $n^{\circ} 4.275$ as pessoas transexuais têm a prerrogativa de solicitarem as alterações de prenome e sexo/gênero em seus documentos e com isso facilitando de maneira importante em suas atividades do dia a dia, como por exemplo, fazer matriculas em escolas e faculdades, poderem colocar o seu nome oficial e legal em um currículo ao saírem em busca de empregos, acessar os serviços públicos de saúde, bem como programas de integração, habitação, além de outros fatores que minoram os atos frequentes e rotineiros de situações vexatórias, uma vez que seus documentos estão em consonância com sua identidade de gênero e jurídica. 
Além do reconhecimento $d$ direito constitucional à não discriminação, é necessário que os ambientes profissionais estejam preparados para acolher, [...]. O uso do nome social, isto é, aquele escolhido pelo trabalhador (a) de acordo com sua autopercepção de gênero, independentemente de suas características somáticas, e a utilização de instalações sanitárias destinadas a tal gênero, são alguns exemplos de boas práticas no acolhimento dessa população. (CAPUTO, 2017, p. 20).

De tal modo, em meio a construção deste trabalho, o executivo municipal de Campina Grande representado pelo senhor prefeito Romero Rodrigues Veiga (gestão 2012-2020) sanciona a Lei de $n^{\circ} 7.520 / 2020$ onde a mesma trata sobre as questões de gênero nas escolas públicas até a $8^{\circ}$ série do mesmo modo estendendo-se para as particulares nas mesmas condições. Segundo o que está posto na referida lei o gênero é e tem que ser entendido único e exclusivamente enquanto construção biológica baseado em caracteres sexuais - corpos genitalizados e sexuados - mulher - vagina, homem - pênis.

De tal maneira, a lei 7.520 aprovada em 25 maio de 2020 pelo executivo municipal veda quaisquer outras formas de manifestações referentes à identidade de gênero - assim sendo, fica estritamente proibida que pessoas Trans não tenham acesso aos vestiários, da mesma maneira aos banheiros de acordo com seus gêneros. Essa lei claramente viola princípios constitucionais como os da dignidade da pessoa humana, intimidade e direito à personalidade, livre expressão, ceifando o direito e o exercício da cidadania.

Grosso modo, essas questões expõem e colocam essas identidades e corpos à margem da sociedade e nesse contexto, do ensino público, este como um dos direitos sociais e que está garantido na Constituição Federal de 1988. Isto posto, medidas como estas incitam o ódio e intolerância por parte do próprio poder público e, por conseguinte, de todo conjunto da sociedade sobre mulheres Transexuais, Travestis e homens Trans, além de pessoas Trans não Binárias.

O efeito de um suposto país democrático é reproduzir apagamentos das condições econômicas, sociais e históricas que produziram determinada realidade, encontrando no indivíduo o início e fim de todas explicações para determinadas exclusões. (BENTO, 2017, p. 57). 
O gênero como elenca Bento (2006) é um construto social, transcorrido por questões culturais, históricas e políticas e que sob quaisquer hipóteses podem ser ignorados esses fatores e segue afirmando que a única verdade do gênero é a prática.

\section{CONSIDERAÇÕES FINAIS}

As discussões difundidas neste trabalho mostra o quanto o Brasil precisa avançar no que concernem a direitos para a população Trans. Com isso, os poucos decretos, projetos de lei e/ou resoluções propostos/criados deveriam vir com o intuito de corrigir as assimetrias sociais e políticas as quais essa população padece estando o tempo todo em constante ameaça.

É uma tentativa de pagamento das identidades e dos corpos Trans ao passo em que se legisla para retroceder e impor condições de reconhecimento no que se refere aos gêneros. "O que está em jogo é a questão sobre se os desamparados estão fora da política e do poder ou se, na verdade, estão vivendo uma forma específica de desamparo político, [...]", (BUTLER, 2019, p. 87). Ou seja, em se tratando das mulheres e homens Transexuais no contexto Brasil e usando uma concepção apontada por Bento (2012) que o que se tem para essa população são gambiarras legais. Não temos, por exemplo uma lei de identidade de gênero como a da Argentina que hoje é a mais avançada do mundo, assegurando que o gênero é autodeclaratório.

No Brasil com a aprovação da ADI n 4.275 - Ação Direta de Inconstitucionalidade garante que pessoas Trans possam requerer alteração de prenome e sexo/gênero no assento de nascimento e nos demais termos de registros. Apesar de não ser lei, no país essa medida tem peso de lei e compreende o gênero enquanto construto social, reconhecendo a autodeterminação de gênero pelo sujeito.

Ademais, mulheres Trans, Travestis e homens Trans podem requerer as alterações em sua documentação juntos aos cartórios de todo país.

Desse modo, antes da aprovação da ADI de $n^{\circ} 4.275$ as retificações em documentos de pessoas Trans se davam obrigatoriamente mediante a apresentação de laudos médicos, ou seja, avaliando por esse prisma o gênero era visito e entendido como uma categoria diagnóstica, o que muito foi criticado por Bento (2006-2012-2017), a autora supra defende o gênero enquanto uma categoria de analise - construção social. 
Com essa mudança as únicas exigências para os cartórios emitirem as novas certidões são solicitadas declarações negativas de débitos (CND) das fazendas públicas municipais, estaduais e federais, do mesmo modo cíveis e criminais, a resposta para essas requisições é para que possam estar resguardados os direitos de outrem.

Os indivíduos precisam ter seus direitos de reconhecimento protegidos em leis constitucionais que garantam a plenitude de suas experiências e vivências na sociedade estando livres de quaisquer formas de discriminações e preconceitos, da mesma forma que estejam livres de vivenciarem em seu cotidiano situações vexatórias.

A importância das alterações de prenome e gênero possibilita esses reconhecimentos e o exercício pleno da cidadania. Percebe-se que ainda que necessitamos percorrer um longo caminho para a plenitude desses direitos, mas se observa que mesmo de maneira precária no que se refere a esses direitos o ordenamento jurídico caminha para um futuro promissor atinentes às identidades e aos corpos Trans.

“O direito à identidade é um direito da personalidade, fulcrado na dignidade humana, no reconhecimento do indivíduo como pessoa e na assunção de esfera intangível dos direitos que não podem ser afastados". (CASTRO, 2016, p. 32).

O Estado enquanto legislador - obriga-se para com seus legislados e legisladas garantias de direitos e seguir favorável, formulando - implementando - implantando Políticas Públicas que deem conta e venham a sanar todas as assimetrias sociais causadas justamente pela ineficiência do próprio poder público nos níveis federal, estadual e municipal em relação às "minorias" sociais que estão sofrendo com ausências de políticas eficientes e eficazes no que tange aos seus direitos mais fundamentais e que são próprios aos seres humanos. "Dessa forma, pessoas transgêneros restam muito visíveis fisicamente e invisíveis socialmente". Caputo (2017, p. 109).

\section{REFERÊNCIAS}

BENTO, Berenice. A reinvenção do corpo: Sexualidade e gênero na experiência transexual. Rio de janeiro: Garamond, 2006.

O que é Transexualidade. São Paulo: editora; Brasiliense, $1^{\circ}$ edição 2008 (Coleção Primeiros Passos: 328) 2 Edição, 2012. 
Berenice. A reinvenção do corpo: sexualidade e gênero na experiência transexual. $3^{\circ}$ ed. /Salvador, BA: Editora Devires, 2017.

CASTRO, Cristina Veloso de. As garantias Constitucionais das pessoas transexauis - 1 . ed. - Birigui, SP: Boreal Editoa, 2016.

Constituição da República Federativa do Brasil. Edição administrativa do texto constitucional promulgado em 5 de outubro de 1988, compilado até a emenda constitucional $n^{\circ} 101 / 2019$.

CONNELL, Raewyn. Gênero em Termos Reais. Tradução; Marilia Moschkovich. --São Paulo, nVersos, 2016.

CAPUTO, Ubirajara de None. $\mathbf{O}$ caso Bruna: gênero, transexualidades e opinião pública. $2^{\circ}$ ed. -- São Paulo: Annablume: PROACSP: governo do Estado de São Paulo, 2017.

BUTLER, Judith. Problemas de gênero: feminismo e subversão da identidade $/ 15^{\circ}$ ed. Judith Butler. Tradução de Renato Aguiar, $15^{\circ}$ ed. - Rio de Janeiro. Civilização brasileira, 2017. - (sujeito e História).

, Judith. Corpos em aliança e a politicas das ruas: notas para uma teoria performativa de assembleia. Tradução Fernanda Siqueira Miguens; revisão técnica Carla Rodrigues. $-3^{\circ}$ ed. - Rio de Janeiro: Civilização brasileira, 2019. 266 p.; $23 \mathrm{~cm}$.

GONÇALVES, Camila de Jesus. Transexualidade e Direitos Humanos: o reconhecimento de gênero entre os direitos da personalidade. Curitiba: Juruá, 2014. 340 p.

SANTOS, Boaventura de Souza; CHAUI, Marilena. Direitos Humanos, democracia e desenvolvimento. - São Paulo: Cortez, 2013.

VENTURA, Miriam. A transexualidade no tribunal: saúde e cidadania. - Rio de Janeiro; EduERJ, 2010. 164p. - (Coleção Sexualidade, Gênero e Sociedade. Homossexualidade e Cultura). 


\title{
CAPÍTULO XII
}

\section{CINEMA QUEER? UMA ANÁLISE DAS OBRAS "FAVELA GAY” (2014) E "DE GRAVATA E UNHA VERMELHA" (2015)}

\author{
Lays Matias Mazoti Corrêa ${ }^{1}$
}

Patrícia Aurora Corrêa Mazoti ${ }^{2}$

\begin{abstract}
${ }^{1}$ Docente da UFV/ Rio Paranaíba-MG, Doutora em Ciências Sociais pela UNESP/Marília, mestre em História pela UNIOESTE/Marechal Cândido Rondon e graduada em História pela UFMS/Três Lagoas. laysmm@gmail.com.

${ }^{1}$ Mestre em Ciências Sociais e graduada em Filosofia pela UNESP/Marília.
\end{abstract}

\section{RESUMO}

Não é de agora que o cinema brasileiro tem trazido novas personagens e temas relacionados a sexualidade e gênero para a discussão. Em razão da organização da mostra "New Cinema Queer: cinema, sexualidade e política" em 2015, a pergunta que se lança é a seguinte: estariam as produções cinematográficas nacionais atuais fomentando um novo cinema queer no Brasil? Nesse sentido, o objetivo deste trabalho consiste em compreender o que foi e/ou é o New Cinema Queer, assim como avaliar o impacto deste movimento na cinematografia brasileira atual. Dado o contexto que ainda se encontra em aberto, mais do que conclusões, o trabalho pretende lançar alguns apontamentos sobre esse curso recente do cinema brasileiro a partir da proposta queer trazida por dois documentários Favela Gay (2014), de Rodrigo Felha e De Gravata e Unha Vermelha (2015), de Miriam Chnaiderman. Ao tomar o cinema como uma instância pedagógica de nossa contemporaneidade, torna-se preciso compreender como esses documentários têm utilizado e se apropriado deste potencial para às molduras do olhar e da sensibilidade de suas plateias. Para tanto, nosso foco se concentrará na narrativa da subversão do gênero e sexualidade que essas obras abarcam, assim como no descentramento que provocam ao apresentar pessoas que não só desafiam as normas sociais, como também as reinventam. Por fim, a abordagem destas produções oportunizará a apreensão de realidades, desejos e afetos que, embora marginalizados socialmente, revelam singularidades, agenciamentos, resistências e, sobretudo, transgressões.

Palavras-chave: New queer cinema. Cinema. Gênero. Sexualidade. Transgressões.

\section{INTRODUÇÃO}

Não é de agora que o cinema brasileiro tem trazido novas personagens e temas relacionados a sexualidade e gênero para a discussão. No entanto, dos anos 2010 para cá, é possível observar o crescimento de produções cinematográficas ficcionais e, sobretudo, as não-ficcionais (documentários) que versam sobre estas questões. Muitas 
destas tem contribuído significativamente não só para a celebração da memória, como também para a inclusão de personalidades de gênero e sexualidades dissidentes na história nacional, como, por exemplo Meu Amigo Cláudia (2009), Dzi Croquettes (2010), Para sempre teu, Caio F. (2015) e Divinas Divas (2017).

Em virtude deste contexto e também da organização da mostra "New Cinema Queer: cinema, sexualidade e política" em 2015, a pergunta que se lança é a seguinte: estariam as produções cinematográficas nacionais atuais fomentando um novo cinema queer no Brasil? Nesse sentido, o objetivo deste trabalho consiste em compreender o que foi e/ou é o New Cinema Queer, assim como avaliar o impacto deste movimento na cinematografia nacional atual. Como esse contexto ainda se encontra aberto, mais do que conclusões, o trabalho pretende lançar alguns apontamentos sobre esse curso recente do cinema brasileiro a partir da proposta queer trazida por dois documentários Favela Gay (2014), de Rodrigo Felha e De Gravata e Unha Vermelha (2015).

Ao tomar o cinema como uma instância pedagógica de nossa contemporaneidade (LOURO, 2000; 2008), torna-se preciso compreender como as produções cinematográficas, em especial, os documentários, têm utilizado e se apropriado deste potencial para promover às molduras do olhar e da sensibilidade de suas plateias. Não pretendemos adensar os pormenores das produções selecionadas, mesmo porque o espaço aqui é pequeno para esta tarefa. Nosso foco se concentra, então, na narrativa da subversão do gênero e sexualidade que essas obras abarcam, assim como no descentramento que provocam ao apresentar pessoas que não só desafiam as normas sociais, como também as reinventam.

2. NOVO CINEMA QUEER NO BRASIL? CINEMA, SEXUALIDADE, GÊNERO E POLÍTICA

Queer não é tanto se rebelar contra a condição marginal, mas desfrutá-la.

(GAMSON, 1995, p. 395 apud COLLING, 2011, p. 2).

Em 2015, a Caixa Econômica Federal, com apoio do governo federal , exibiu a mostra "New Queer Cinema: cinema, sexualidade e política" em algumas capitais brasileiras, como Curitiba, Fortaleza, Salvador, São Paulo e Rio de Janeiro, sob curadoria de Denilson Lopes e Mateus Nagime. A publicação que acompanhou o catálogo dos 
filmes que foram exibidos enfatiza que seu objetivo é fomentar "a discussão sobre cinema queer no Brasil, seja por autores e pesquisadores brasileiros, seja por uma cinematografia (trans)nacional" (MURARI; NAGIME, 2015, p. 08). Nela, há textos teóricos que versam sobre o fenômeno e o conceito New Queer Cinema, a análise de diversas obras cinematográficas do mundo todo que se enquadram na referida proposta, assim como o papel das mídias digitais contemporâneas na difusão de produções de estética queer sobre outros formatos como música, videoclipes e vídeos experimentais.

Dentre os filmes selecionados para à mostra, foram exibidas produções representativas do New Queer Cinema, sendo estas, em sua maioria, realizadas nos Estados Unidos, como Garotos de Programa (1991), Canadá, Paciência Zero (1993) e Reino Unido, Edward II (1991), para citar algumas. Visando cumprir com o objetivo da mostra no fortalecimento de um cinema queer nacional, os filmes brasileiros selecionados eram recentes e compreenderam as seguintes produções na ordem de exibição: O animal sonhado (2015), Batguano (2014), Doce Amianto (2013), Tatuagem (2013), Estudo em vermelho (2013) e Na sua companhia (2012).

Mas, afinal, o que seria o New Queer Cinema? Para Murari e Nagime, foi um movimento político, social e artístico articulado em virtude da crise da aids nos Estados Unidos nos anos de 1980 e 1990, dada a falta de políticas públicas e também do aumento do preconceito contra homossexuais. Ele foi new (novo) naquele momento, pois buscou combater a visão conformada e conciliadora do cinema de então, este que apresentava homossexuais, transgêneros e bissexuais a partir de "uma visão que se apresenta inclusiva, mas na verdade funciona apenas para validar uma visão heteronormativa, e geralmente acompanhada da figura dominante do homem branco" (MURARI; NAGIME, 2015, p. 12).

Como é possível perceber, o contexto histórico que fomentou o New Queer Cinema nos Estados Unidos abarca as origens históricas da própria teoria queer como nós a conhecemos hoje. Embora o queer remeta-se mais precisamente a década de 1980, seu surgimento "se insere em um cenário aberto pelos novos movimentos sociais surgidos duas décadas antes, sobretudo o movimento pelos direitos civis nos Estados Unidos, o movimento feminista e o movimento homossexual" (MISKOLCl, 2012, p. 13). 
É no final da referida década - também em virtude do surgimento da crise da aids nos Estados Unidos - que a teoria queer se cristalizaria. Isso porque, diferente da experiência brasileira, lá o enfrentamento da epidemia não contou com o apoio do Estado, pelo contrário, "houve um verdadeiro choque entre as demandas sociais e a recusa do governo conservador de Ronald Reagan em adotar quaisquer medidas" (MISKOLCl, 2012, p. 23).

Em outras palavras, tanto o New Queer Cinema quanto o que viria a se tornar a teoria queer participaram e se alimentaram do próprio processo de reavaliação dos movimentos sociais, em especial o homossexual e o feminista do chamado Terceiro Mundo, esses que, no final dos anos de 1980, começaram a trazer críticas quanto ao seu caráter ocidental, branco e de classe média e a priorização de outras demandas: "enquanto o movimento mais antigo defendia a homossexualidade aceitando valores hegemônicos, os queer criticam esses valores, mostrando como eles engendram as experiências da abjeção, da vergonha, do estigma" (MISKOLCI, 2012, p. 25).

Dessa forma, o New Queer Cinema configurou-se como uma ação política através da arte. O conceito em si foi cunhado pela estadunidense e crítica de cinema B. Ruby Rich em 1992. Na ocasião, a autora escreveu um artigo sobre o surgimento de um conjunto de filmes apresentado no Festival dos Festivais de Toronto em 1991 que, para ela, apresentavam as novas tendências cinematográficas: a "queer sensation" (RICH, 1992). Dada a repercussão de seu texto, o mesmo foi reimpresso no mesmo ano sob um novo título que passaria a designar esse movimento cinematográfico: The New Queer Cinema. Para Rich, tratava-se de produções que estavam "fazendo algo novo, renegociando subjetividades, anexando gêneros inteiros, revisando histórias em suas imagens. Ao longo de todo o inverno, da primavera e do verão, a mensagem foi alta e clara: queer é sexy" (RICH, 2015, p. 18).

Rich destacou que tais produções não compartilhavam de "um único vocabulário estético, estratégia e preocupação" (RICH, 2015, p. 20), mas que, mesmo assim, poderiam ser agrupadas num conjunto, pois as obras apresentavam traços

de apropriação, pastiche e de ironia, assim como uma relaboração da história que leva sempre em consideração um construtivismo social. Definitivamente rompendo com abordagens humanistas antigas e com os filmes e fitas que acompanhavam políticas da identidade, essas 
obras são irreverentes, enérgicas, alternadamente minimalistas e excessivas. Acima de tudo, elas são cheias de prazer. Elas estão aqui, elas são queer, acostume seus quadris a elas (RICH, 2015, p. 20).

Curiosamente, o furor do New Queer Cinema dissipou-se quando este alcançou o mainstream, diluindo-se em meio ao vasto catálogo das produções cinematográficas do momento. Em outras palavras, ainda que o movimento tenha contribuído para estremecer a indústria cinematográfica norte-americana, o potencial transgressivo do New Queer Cinema arrefeceu-se diante da fixidez estrutural do mainstream cinematográfico que limita a liberdade artística dxs criadorxs.

As perguntas que ficam então são: as produções cinematográficas brasileiras de 2010 podem ser compreendidas como um novo cinema queer nacional tal como colocaram os curadores da mostra ocorrida aqui no Brasil em 2015? Se até hoje ainda não há consenso entre os pesquisadores da área sobre a proposta política e estética do New Queer Cinema e ainda existe o questionamento do que foi/é novo nesse movimento, a resposta parece então estar distante (BESSA, 2014, p. 54).

No entanto, se tomarmos as orientações de Karla Bessa quando ela ressalta que o queer cinematográfico deve priorizar a problematização "de nossas convenções e verdades acerca da sexualidade e do gênero, rompendo binarismos ('homem versus mulher', heterossexualidade versus homossexualidade, etc)" (BESSA, 2014, p. 54), a resposta seria sim, uma vez que é possível identificar essas características num conjunto diverso de produções cinematográficas nacionais dos anos de 2010.

Desse questionamento, outro se origina: assim como o New Queer Cinema norteamericano, estaria o novo cinema queer brasileiro ameaçado diante do mainstream? Ou melhor, estaria o cinema brasileiro passando por esse processo atualmente? As perguntas são pertinentes porque é possível perceber o surgimento de um conjunto de filmes de temática $\operatorname{LGBTQIA}+^{1}$ que, embora tenham enfrentado dificuldades em adentrar o circuito comercial, foram veiculados para o grande público das salas de cinema, como por exemplo: Flores Raras (2013), o já mencionado Tatuagem (2013), Hoje eu quero voltar sozinho (2014), Praia do Futuro (2014), A Glória e a Graça (2017), dentre outros.

\footnotetext{
${ }^{1}$ Lésbicas, gays, bissexuais, travestis, transexuais, queer, intersexos, assexuais, dentre outros.
} 
Ainda que essas produções apresentem estéticas inovadoras que desafiam a indústria cinematográfica nacional, é possível perceber nas obras de maior apelo comercial, como Flores Raras e A Glória e a Graça (ambas produzidas pela Globo Filmes), certas acomodações à norma, restringindo-se a tarefa de humanizar as personagens de gênero e sexualidades dissidentes e apresentá-las como parte da sociedade atual.

Paralelamente a este processo, o cinema brasileiro contemporâneo tem também registrado um aumento significativo de produções não-ficcionais, documentários, cujo enredo privilegiam uma proposta queer, isto é, propõe o combate à abjeção dos corpos de pessoas de gênero e sexualidades dissidentes, esboçando, assim, possibilidades de existências a partir da reinvenção de resistências contra a heteronormatividade e "às normas de inteligibilidade cultural" dos gêneros (BUTLER, 2003, p. 39). O aumento dessas produções é significativo uma vez que o documentário ocupa uma posição marginal se comparado ao cinema de ficção. As barreiras comerciais presentes na crença que documentário não rende bilheteria limitam a visibilidade e apreciação deste tipo de produção, fazendo com que tal obra não consiga atingir o grande público.

Em outras palavras, os documentários não circulam efetivamente nas grandes telas de todo país, e quando o fazem, restringem-se aos grandes centros urbanos. Apesar disso, a visibilidade e crítica dessas produções têm sido oportunizadas através de cine debates organizados por instituições universitárias, como o CinePagu da UNICAMP, comerciais, como o SESC (Serviço Social do Comércio), além de organizações não-governamentais (ONGs) e estabelecimentos destinados para a promoção de cultura e arte.

Também se destacam nesse enredo as mostras organizadas pelos festivais de cinema, sejam aqueles destinados à seleção de obras que abordem temáticas sobre gênero, sexualidade e direitos humanos, como também os festivais nacionais. Esse conjunto compreende então desde as agremiações mais consagradas, como o Festival MixBrasil de Cultura da Diversidade, Festival de Brasília do Cinema Brasileiro, Festival de Gramado, Mostra de Cinema de Tiradentes e Festival do Rio, como também outras criadas recentemente, como Olhar de Cinema: Festival Internacional de Curitiba; Festival da Diversidade Sexual e de Gênero (Recifest) e Festival Periferia Trans de São Paulo, para citar algumas. 
Ainda que a circulação restrita dessas obras seja negativa quanto ao seu alcance pedagógico, esta mesma característica apresenta um potencial mais libertário a essas produções, engendrando uma saída diante da acomodação normativa que o mainstream exerce sobre o cinema brasileiro. Em outras palavras, a escolha por este tipo de produção e a representação de histórias reais pode ser compreendida também como expressão de resistência frente aos modelos impostos pela indústria cinematográfica nacional.

$\mathrm{Na}$ contemporaneidade, a limitação orçamentária geralmente imposta às produções dos documentários compensa-se a partir do "barateamento da produção fílmica com o uso de câmeras digitais e softwares de edição. A ideia na cabeça e câmera na mão continua sendo um potencial transgressor que libera a criatividade para fora dos esquemas narrativos e cinemáticos dos filmes de alto custo" (BESSA, 2014, p. 54). A estética e o apelo da crítica queer em muitas dessas produções também podem ser entendidas a partir do contexto histórico atual, uma vez que a visibilidade de personagens de gênero e sexualidades dissidentes na mídia tradicional, em especial, nas novelas, e também em outras produções artísticas, como a música, já é um fato consumado.

No entanto, a espetacularização social desencadeada por esse processo tem contribuído ainda mais para o confinamento destas pessoas às zonas de abjeção, dada as reações violentas, perseguições políticas, ataques verbais e físicos cometidos por grupos conservadores e religiosos ortodoxos (BESSA, 2014, p. 54). Em outras palavras, o questionamento da heterossexualidade, ainda que seja importante, é suficiente para a superação do estigma, da ofensa e da abjeção, mesmo porque esse processo tem sido conduzido a partir da política da tolerância, isto é, através da (re)integração das pessoas de gênero e sexualidades dissidentes às normas sociais. Assim, as práticas sociais e políticas queer não direcionam suas forças para o questionamento da heterossexualidade, mas sim na luta contra a abjeção, pois

a problemática queer não é exatamente a da homossexualidade, mas a da abjeção. Esse termo, 'abjeção', se refere ao espaço que a coletividade costuma relegar aqueles que aquelas que consideram uma ameaça ao seu bom funcionamento, à ordem social e política. (....) A abjeção, em termos sociais, constitui a experiência de ser temido e recusado com repugnância, pois sua própria existência 
ameaça a visão homogênea e estável do que é a comunidade. (MISKOLCl, 2012, p. 24).

É justamente sobre esta questão que alguns documentários produzidos recentemente dedicaram suas abordagens. Ao utilizar um formato mais tradicional de documentário, isto é, a partir da abordagem de entrevistas, o que se procura destacar não é a estética selecionada, mas as histórias, questões, problemáticas e resoluções vividas pelas pessoas entrevistadas. De Gravata e Unha Vermelha (2015), da cineasta e psicanalista Miriam Chnaiderman, problematiza a ordem cultural compulsória entre sexo/gênero/desejo a partir do relato de pessoas travestis, transexuais, homossexuais e também aquelas que realizam diferentes experimentações de gênero. A obra ganhou $O$ Prêmio Félix como o melhor documentário de temática LGBT no Festival do Rio de 2014.

Ainda que se perceba uma clara tendência em privilegiar a abordagem de experiências e vivências das pessoas conhecidas no universo artístico e/ou da militância LGBTQIA+ - como a cartunista Laerte, a atriz Rogéria, o cantor Ney Matogrosso, o estilista Dudu Bertholini, o DJ e modelo Johnny Luxo, o primeiro transexual brasileiro João Nery, a cantora Candy Mel, a presidente da Associação Brasileira de Transgêneros Letícia Lanz, o designer de chapéus Eduardo Laurino, o estilista de drag queens Walério Araújo, o ator Léo Moreira Sá, o ex-Dzi Croquettes Bayard Tonelli - o documentário buscou mesclar esses relatos com outros emitidos por pessoas comuns, "anônimas", como a transexual que espera pela cirurgia de redesignação sexual Tais Gomes, a professora Bianca Soares, Samantha Aguiar, o produtor rural Benedito Messias Magalhães e os mecânicos Giovani Vieira da Costa e Jefferson Batista de Araújo.

Esses últimos, são homens heterossexuais que começaram a se vestir de mulher como uma brincadeira entre amigos, mas que acabou virando uma tradição carnavalesca celebrada e ansiada anualmente. Em seus relatos, ressaltam que vestir-se como mulher não ameaça suas masculinidades, pelo contrário, por vezes, conforme Giovani, acaba sendo um facilitador para se relacionar sexualmente com as mulheres.

Embora a maioria dos relatos sejam marcados pelo peso ainda carregado do estigma, do preconceito e pelas dificuldades de aceitação familiar e social, suas falas registram o processo que permeou e/ou ainda permeia a travessia de gênero, isto é, a construção subjetiva de suas identidades de gênero. O que se destaca é, justamente, a 
multiplicidade, por exemplo, de experiências transexuais: enquanto algumas pessoas anseiam pela cirurgia de redesignação sexual, outras não abdicam do desejo que seus órgãos genitais oferecem, como Letícia Lanz, que se coloca como "uma mulher com pênis".

A quebra da coerência entre sexo/gênero/desejo imposta pela matriz heterossexual se exacerba em duas situações: primeiro no relato de Dudu Bertholini, que declara gostar do seu corpo masculino, de se relacionar sexualmente com homens e também de fazer experimentações de gênero, mesclando elementos do universo masculino e feminino, o que, por sua vez, para ele, o faz ser um genderfucker. Segundo, na vivência de Letícia Lanz. Sua transição de gênero ocorreu aos 50 anos, depois de três décadas de seu casamento. Esse processo, no entanto, não a conduziu ao enquadramento da norma, isto é, não a levou a manter uma "relação de coerência e continuidade entre sexo, gênero, prática sexual e desejo" (BUTLER, 2003, p. 38), já que não alterou o seu desejo por mulheres e, por isso, continua casada até hoje com a psicóloga Ângela Dourado.

Mas se nessa produção as vivências e experiências das pessoas comuns foram ofuscadas, Favela Gay (2014) realiza o inverso, trazendo para o centro do debate pessoas de gênero e sexualidades dissidentes que se encontram nas margens da sociedade carioca, mais especificadamente, nas comunidades Rio das Pedras, Rocinha, Cidade de Deus, Andaraí, Complexo da Maré, Vidigal e Complexo do Alemão.

Dada a junção das duas palavras que compõe o título do documentário, é possível imaginar as dificuldades sociais e financeiras encontradas para sua produção. Isso não impediu, no entanto, que a obra vencesse o prêmio de melhor documentário pelo voto popular no Festival do Rio, também de 2014.

O enredo que sustenta toda a produção reúne os relatos de doze entrevistadxs: o maquiador e drag queen Maxwell, xs cabelereirxs Martinha e Flávio, a universitária Rafaella, o coreógrafo de escola de samba Carlinhos do Salgueiro, a ativista Gilmara, o casal de cantoras Dejah Idalice e Jeckie Brown, o presidente do Grupo Diversidade LGBT do Complexo do Alemão Luiz Moura (Guinha); as prostitutas Michelli e Pandora. A única pessoa "pública" entrevistada foi o deputado Jean Willys, eleito pelo Rio de Janeiro. Como se observa, a escolha do título não foi muito feliz, já que a designação gay não representa as vivências e experiências múltiplas de todas as pessoas entrevistadas, já 
que incluem mulheres transexuais (Martinha, Rafaella e Gilmara), travesti (Pandora) e lésbicas (Dejah e Jeckie), além de homossexuais.

A maioria dos relatos buscaram enfatizar como foi o processo de aceitação própria e social de sua sexualidade e da travessia de gênero num contexto em que a violência, o tráfico, as drogas e a prostituição se fazem recorrentes. Neles, percebe-se a ênfase dada ao enfrentamento da abjeção e a superação do estigma, da vergonha e do preconceito através dos estudos, da arte, da dança, da música e/ou do ativismo. Curiosamente, foi justamente essa questão que se destacou, negativamente, em grande parte das críticas realizadas sobre o filme. O otimismo da superação e a construção de um orgulho identitário incomodou a crítica, fazendo-a ressaltar que a obra não conseguiu atingir a complexidade e profundidade das questões tratadas em seus contextos sociais específicos, prendendo-se somente na narrativa dxs entrevistadxs selecionadxs.

Ao assistir o documentário, é possível perceber que esta foi uma escolha de enredo: não conduzir a fala das pessoas para que elas pudessem, com autonomia e liberdade, narrar o que queriam visibilizar de si, de suas experiências e vivências. Assim, as questões narradas não são tratadas com profundidade intencionalmente, o único que ensaia fazer isso, nos breves momentos em que aparece, é Jean Willys, cuja fala é direcionada para revelar o próprio objetivo da obra: apresentar existências e resistências possíveis.

É interessante pensar o porquê isso incomodou parte da crítica, já que a produção parece ter frustrado as expectativas que ansiavam por relatos de experiências marcados somente pelos preconceitos, violências e tragédias. Nenhumx dxs entrevistadxs "coloriram" suas experiências, pelo contrário, enfatizaram a influência direta do tráfico, da prostituição, das drogas nas suas vidas, destacando, inclusive, que, por vezes - como relatado por Rafaella, Flávio e Guinha - tiveram que lançar mão da violência verbal e física para se protegerem e conseguirem respeito.

No entanto, é preciso perceber que não é somente essas questões que permeiam suas vidas: há também muito carnaval, bailes funks e gaymados (jogo de queimada cujos participantes são LGBTQIA+). Por isso, muitxs fizeram questão de ressaltar como a vida em suas comunidades melhoraram nos últimos anos, tornando-se possível, por exemplo, a organização das primeiras Paradas Gays de suas comunidades. 
Embora os relatos possam ser agrupados num conjunto, dada a tônica da superação dos estigmas sociais que os norteiam, não há um caráter uníssono das experiências narradas. Enquanto Martinha conta, com orgulho, o início de sua transição de gênero que se deu a partir do reconhecimento das transexuais mais velhas de sua comunidade por meio de seu "batizado" simbólico, Pandora apresenta uma experiência diferente. Embora não se coloque como travesti ou como transexual é possível perceber seus medos e angústias nesse processo de travessia de gênero. Diferente dos outros momentos em que foi entrevistada, no final do documentário, ela aparece sem peruca, sem maquiagem, usando short e camiseta. Ali, ressalta ter se aproximado da religião, essa que, embora parece ter contribuído para se afastar da prostituição, também foi determinante para que começasse a se ver de forma "diferente" e "estranha", levandoa "tomar raiva da Pandora".

Ainda que tenha optado por se apresentar somente com esse nome, na sua fala, Pandora passou a surgir como uma espécie de alter ego, diz ela: "Eu não quero mais a Pandora! Eu tô bem, tô muito bem assim! Ela ganhava muito num dia e gastava tudo naquele dia! Ela não pensava no amanhã". Na sua percepção, foi todo esse processo e também o alto custo da manutenção de Pandora, de suas perucas, implantes, roupas, maquiagens e unhas, que a levou se desfazer dela: "peguei ela, guardei ela na caixinha de Pandora, botei ela no mar e ela foi embora. Ela seguiu o rumo dela e agora eu não sei qual é o destino. Não sei pra onde ela vai parar. Faço nem noção, onde é que aquela caixa vai parar. Quem abrir, não sei o que vai acontecer! (risos)".

O documentário se encerra, mas as vidas narradas seguem. Será que Pandora permaneceu, de fato, em sua caixa? Felizmente parece que não. Um ano depois, as fotografias do Festival do Rio de 2014 registraram seu ressurgimento com seus longos cabelos pretos, brincos, vestido e salto alto. Não se sabe, hoje, se ela permaneceu ou se voltou para a caixa. Apesar disso, Pandora nos ensina muito ao evidenciar que o gênero é, de fato, um processo que se constrói socialmente e se reinventa subjetivamente. 


\section{CONSIDERAÇÕES FINAIS}

Como fechar um texto que trata de um contexto cinematográfico aberto e que ainda pode tanto surpreender como decepcionar? Apesar dessa difícil tarefa, o caminho é tentar responder a pergunta estabelecida anteriormente: há um novo cinema queer no Brasil? De fato, não é possível identificar com precisão o que é "novo" nestas produções, mesmo porque muitas das propostas trazidas pelas obras ficcionais e não ficcionais contemporâneas já ilustraram muitas produções de outrora, como Vera (1986) que evidenciou o cotidiano de uma pessoa que nasceu biologicamente como Vera, mas que lutava para ser Bauer (BESSA, 2014, p. 52) e também as personagens Ângela Carne Osso de A mulher de todos (1969), a Rainha Diaba (1974) e Madame Satã (2002) que chacoalharam os valores morais de sua época ao desafiar os limites da feminilidade e da masculinidade na construção de suas subjetividades.

Ainda que as produções cinematográficas contemporâneas não tragam elementos totalmente "novos" e "inéditos", é possível identificar um certo aprofundamento das questões e problemáticas que norteiam gênero e sexualidades. Nesse processo, os documentários se sobressaem, uma vez que seu potencial transgressivo na recusa ao enquadramento às normas e convenções sociais se apresenta de forma mais explícita. Nessas produções já se faz presente o uso de novos vocabulários e a apresentação de novas reinvenções de ser, existir e resistir.

O documentário de média-metragem Bichas, o documentário (2016) é um exemplo desse processo. A iniciativa partiu do publicitário Marlon Parente que, após viver um episódio de homofobia em que ele e alguns amigos foram ameaçados com uma arma, pegou uma câmera emprestada e reuniu o relato de experiências e vivências de seis amigos - Bruno Delgado, Igor Ferreira, Ítalo Amorim, João Pedro Simões, Orlando Dantas e Peu Carneiro - como uma forma de superar a situação de impotência e desespero frente a homofobia e violências que muitas pessoas, como ele próprio, já vivenciaram. Detalhe: o único investimento de Marlon Parente para a produção de Bichas foi a aquisição de um microfone que custou dez reais. A distribuição e divulgação do filme foi realizada a partir da plataforma YouTube. Atualmente, o documentário já contabiliza aproximadamente 937 mil visualizações. 
Todos os entrevistados se apresentam orgulhosamente como bichas. Ao lado dos relatos das suas primeiras experiências sexuais e das dificuldades de "sair do armário" para a família e para a sociedade, narram também o processo que os conduziram para a ressignificação da ofensa "bicha" e "viado" na construção de suas subjetividades, conformando, assim, um orgulho identitário.

Para eles, a ofensa só obtém seu efeito negativo quando ela é entendida como insulto e rejeitada pela pessoa que a recebeu. Quando esta não a concebe enquanto uma humilhação, mas como parte de seu ser e de seu orgulho, ela consegue neutralizar o rebaixamento e a vergonha que a configuram. Dessa forma, semelhante ao inglês queer que foi incorporado e ressignificado pela teoria queer, no documentário, de um xingamento, bicha transforma-se não só enquanto um mecanismo de defesa, mas também como sinônimo de liberdade e transgressão.

Também é importante ressaltar que os documentários brasileiros contemporâneos têm trazido à tona discussões invisibilizadas dentro do próprio meio LGBTQIA+, dado a permanência do seu caráter branco, masculinista e homossexual. É possível perceber um aumento no número de produções que narram não só as múltiplas experiências de pessoas transexuais e travestis, mas também as vivências interseccionais entre gênero, sexualidade e raça como as produções de Meu corpo é político (2017), de Alice Riff e Bixa Travesty, de Kiko Goifman e Claudia Priscilla (2018), essa última baseia-se na vida da artista trans paulistana Linn da Quebrada, que também foi uma das entrevistadas da obra de Alice Riff.

Grande parte das produções citadas ao longo deste trabalho incorporaram a proposta queer no fazer cinematográfico. Dessa forma, a escolha pela produção de documentários pode então ser compreendida como uma estratégia para impedir que aconteça o mesmo processo do New Queer Cinema nos Estados Unidos: evitar que o queer perca seu potencial e se torne conformado no mainstream, fazendo com que prossiga promovendo não só um aprendizado pelas diferenças, mas sobretudo, pelas transgressões. Diante da política de retrocesso que estamos vivendo, a qual desencoraja o debate de gênero, sexualidade e o fomento do próprio cinema nacional, não é possível saber se este movimento histórico continuará a ter desdobramentos, mas certamente permaneceremos aqui ansiosxs e esperançosxs para futuras produções. 


\section{REFERÊNCIAS}

BESSA, Karla A teoria queer e os desafios às molduras do olhar. In: Revista Cult, São Paulo, n 193, ago-2014, p. 48-54.

BUTLER, Judith. Problemas de gênero. Feminismo e subversão da identidade. Rio de Janeiro: Civilização Brasileira, 2003.

COLLING, Leandro. Teoria Queer, 2011. In: ALMEIDA, Maria Cândida Ferreira de (org.). Mais Definições em Trânsito. Disponível em <http://www.cult.ufba.br/wordpress/?page_id=823>. Acesso em 04 mar 2018.

LOURO, Guacira. O Cinema Como Pedagogia. In: LOPES, Eliana e outros (Orgs.). 500 Anos de Educação no Brasil. Belo Horizonte: Autêntica, 2000. . Cinema e sexualidade. In: Educação e Realidade. Jan/jun. 2008. Vol. 33, no 1, p. 81-98.

MISKOLCl, Richard. Teoria Queer: um aprendizado pelas diferenças. Belo Horizonte: Autêntica Editora, 2012.

MURARI, Lucas; NAGIME, Mateus (orgs). New Queer Cinema - cinema, sexualidade e política. São Paulo: Caixa Econômica Federal, 2015.

RICH, B. Ruby. New gay film. A queer sensation. In: The Village Voice, march 24, 1992.

. New Queer Cinema. In: MURARI, Lucas; NAGIME, Mateus (orgs). New Queer Cinema - cinema, sexualidade e política. São Paulo: Caixa Econômica Federal, 2015. 


\title{
CAPÍTULO XIII
}

\section{CINEMA, GÊNERO E SEXUALIDADE: A PRODUÇÃO DE (IN)VISIBILIDADES EM "A GLÓRIA E A GRAÇA" (2016)}

\author{
Lays Matias Mazoti Corrêa ${ }^{1}$ \\ Patrícia Aurora Corrêa Mazoti ${ }^{2}$
}

\begin{abstract}
${ }^{1}$ Docente da área de Sociologia e Antropologia da Universidade Federal de Viçosa, campus de Rio Paranaíba-MG. Doutora em Ciências Sociais pela UNESP/Marília-SP, mestrado em História pela UNIOESTE/Marechal Cândido Rondon-PR e licenciatura em História pela UFMS/Três Lagoas-MS.

${ }^{2}$ Mestre em Ciências Sociais e graduada em Filosofia pela UNESP/Marília.
\end{abstract}

\section{RESUMO}

"Ser trans não significa ter talento para viver uma trans", disse Gloria Perez a respeito da personagem transsexual apresentada na novela da Globo, "A força do querer" (2017). Este anúncio causou debates na comunidade trans que reivindicava a criação de um espaço de visibilidade para atrizes e atores transsexuais, oportunizando, assim, papeis de protagonistas. Essa problemática já tinha sido colocada no lançamento realizado pela Globo Filmes e Canal Brasil de "A Glória e a Graça" (2016), filme que apresenta uma protagonista travesti, Glória, interpretada por Carolina Ferraz. Pensando nesses aspectos, o presente trabalho apresenta uma leitura deste filme, utilizando-se de problematizações construídas a partir do aporte teórico queer. O objetivo é compreender esta abordagem, atentando-se para o alcance e os limites de visibilidade(s) às pessoas travestis engendrado pela película. Ao tomar o gênero e a sexualidade como constructos históricos e sociais, o cinema apresenta-se como um meio articulador de discursos e marcações sociais que evidenciam o jogo de disputas pelos significados de práticas e identidades sociais e culturais que se fazem em voga. Por fim, ao perceber a importância da construção desses discursos que, por vezes, tomam a forma e obtém o estatuto de verdade, propomos uma reflexão sobre a relação entre cinema, gênero e sexualidade para contribuir no debate dessas questões.

Palavras-chave: Cinema. Travestilidade. (In)visibilidades.

\section{INTRODUÇÃO}

"Ser trans não significa ter talento para viver uma trans", disse Gloria Perez sobre a personagem transsexual apresentada na novela da Globo, "A força do querer" (2017). Foi em meio aos debates gerados por estes dizeres na comunidade trans que tomamos contato com o filme "A Glória e a Graça” (2016). O contexto de lançamento desta obra, bem como as questões por ela abordadas possibilitam uma reflexão entre cinema, gênero e sexualidade. 
Ao tomar o gênero e a sexualidade como constructos históricos e sociais, o cinema apresenta-se como um meio articulador de discursos que evidenciam o jogo de disputas pelos significados de práticas e identidades que se fazem em voga. O objetivo deste trabalho, então, busca compreender o alcance e os limites de visibilidade(s) à travestis e transexuais propiciados por esta obra cinematográfica.

\section{A TRAVESSIA DE GÊNERO DE GLÓRIA}

Produzido pela Globo Filmes, Canal Brasil, Tambellini Filmes, H2O Films e dirigido por Flávio Ramos Tambellini, o filme é protagonizado por Carolina Ferraz, uma atriz cis ${ }^{1}$ que realiza o papel de Glória, uma travesti bem sucedida que, diante da doença fatal de sua irmã, Graça (Sandra Corveloni), se aproximará dela, responsabilizando-se pelos cuidados de seus filhos, Papoula (Sofia Marques), de 15 anos, e Moreno (Vicente Demori), de 8 anos. O roteiro conta com a participação da modelo e atriz trans Carol Marra, no papel de Fedra, como atriz e amiga de Glória.

Apesar de seu lançamento datar-se de 2016, o roteiro já existia há muito tempo, mais precisamente, há quase dez anos. Em diversas entrevistas, Carolina Ferraz, detentora dos direitos autorais do roteiro, relatou as dificuldades e os preconceitos encontrados na captação de recursos financeiros para a producão da obra.

Neste sentido, o lançamento recente da obra deve ser entendido como parte dos avanços da sociedade brasileira que tem requerido maior atenção para o debate sobre representatividade de gênero, pressão social que, inevitavelmente, atinge a grande mídia, justificando a emergência destas questões nos programas televisivos e na teledramaturgia brasileira. Entretanto, será que essa visibilidade e representatividade de gênero vivida contemporaneamente pela sociedade brasileira retira travestis e transexuais do espaço da abjeção (BUTLER, 2003)?

O filme em questão promete, justamente, corroborar com esse processo e humanizar a figura de travestis e transexuais. A obra é dividida em dois planos: a realidade de Graça, mãe solteira, que enfrenta o drama de lidar com a notícia de sua doença terminal e traçar o futuro de seus filhos; e a vida de Glória que, após distanciar-

${ }^{1}$ Cisgênero (cis) é um conceito utilizado para designar as pessoas que se identificam com o gênero indicado no nascimento. 
se de sua família, sofrer inúmeras violências e viver dificuldades financeiras e afetivas encontra-se no melhor momento de sua carreira, como proprietária de um restaurante badalado no Rio de Janeiro, corroborando, assim, com o discurso meritocrático.

Após 15 anos sem ver Glória, o estranhamento de Graça diante do corpo feminino daquela que antes conhecia como Luís Carlos diluiu-se na emoção do reencontro. No entanto, terminado o abraço, Graça observa “- Nossa, como seu peito é duro!", referindo-se à transformação de Luís Carlos em Glória. Esta relata que sua transformação foi um longo processo que se iniciou depois de sua saída da casa de sua família.

Ainda que este diálogo forneça a impressão que o processo se findou após as intervenções cirúrgicas, em outro momento Glória aparece aplicando, em si própria, hormônio, fato que coloca a travessia de gênero como um incessante devir: "'Ser travestis' é um processo, nunca se encerra. Construir um corpo e cuidá-lo é uma das maiores preocupações das travestis. Elas estão sempre buscando a 'perfeição', o que significa 'passar por mulher', uma mulher bonita e desejável [...]" (PELÚCIO, 2005, p. 224).

Graça elogia a irmã, dizendo que ela está "vistosa". Glória, sem hesitar, rebate, com orgulho, sua identidade de gênero e passabilidade: "Vistosa, meu amor, é a Carmem Miranda com uma salada de frutas na cabeça. Eu sou lindA!"1.

Graça a interrompe e comunica seu estado de saúde, revelando o desejo que sua irmã conhecesse seus filhos e estivesse por perto. Glória, apesar de se sensibilizar com sua situação, indaga o porquê do reencontro não ter acontecido antes, há cinco ou dez anos atrás. Na discussão, Graça a chama de Luís Carlos e, mais uma vez, ela tem que reafirmar sua identidade de gênero a irmã: “- Glória! Meu nome é Glória!”. Graça pede para que ela esqueça o passando diante de sua necessidade de planejar o futuro de seus filhos e a convida para jantar em sua casa. Mesmo assim, diante da mágoa, Glória não fraqueja. Ela enaltece tudo que conquistou sozinha e o quanto sua vida naquele momento está ótima, despedindo-se de sua irmã.

${ }^{1}$ Apesar de Carolina Ferraz em algumas entrevistas revelar o desejo de se desvencilhar da referência icônica de seu papel realizado na novela "Beleza Pura" (2008) em que sua personagem exclamava "Eu sou ricA!", sua interpretação de Glória por vezes remeteu-se a esta referência, como na entonação utilizada na frase "Eu sou lindA!". 
A película passa a focalizar mais o cotidiano de Glória, seu trabalho no restaurante e a sua casa que acomoda também sua amiga Fedra, a quem relata o reencontro com sua irmã e a mágoa que persiste. Pela manhã, Glória encontra na bolsa Prada que havia emprestado a Fedra na noite anterior uma grande quantia de dinheiro. Ela acorda Fedra e indaga sobre a origem do dinheiro. Fedra responde dizendo que foi um amigo que lhe deu, gerando, então uma discussão:

Glória: Mas é impressionante como você tem a cara de pau de mentir para mim essa hora da manhã quando, na verdade, o que cê fez foi sair por aí piranhando!

Fedra: Ah Glória, me deixa em paz...

G: Hum, paz! Você quer é se fuder isso sim!

F: Vou me trocar que eu já tô atrasada.

G: Sabe qual é o seu problema, Filipe de Alcântara? Você é burro!

F: Qual é cara? Vai me dar lição de moral? Até parece, né, que você nunca fez isso antes!

G: Você não entende. Você não entende que a única pessoa que sai prejudicada nessa história toda é você! Só você se fode! Só você fica fudida, tá pensando o quê? Que é a belle le jour (risos), que vai sair por aí rodando bolsinha na Lapa e vai encontrar o príncipe encantado... Que planeta você vive? Vive no mundo da fantasia... Eu cansei de cuidar de você!

F: Você não precisa cuidar de mim, Glória. Cuida de seus sobrinhos. Eles é que precisam de uma mãe.

A reprovação moral de Glória indica sua preocupação diante da realidade de violências que circunda o universo da prostituição. Ao mesmo tempo, aponta que a prostituição, por vezes, é tomada por travestis e transexuais como única possibilidade de realização de seus desejos sexuais e amorosos, já que seus corpos são tomados socialmente como abjetos, "habitantes de zonas inóspitas da vida social, povoadas por aqueles que não gozam do status de sujeito" (COLLING; PIRAJÁ, 2011, p. 514) dada a sua não conformação "às normas de inteligibilidade cultural" (BUTLER, 2003, p. 39) alicerçada no padrão biológico binário que designa o que é ser mulher ou homem, assim como os papeis sociais e comportamentos sexuais esperado dos mesmos, tidos como naturais ou normais.

A questão retorna na trama quando Glória, desnorteada por descobrir que o pai de sua sobrinha é o seu ex-namorado - o único homem que amou na vida e que flagrou na cama com sua irmã -, percorre uma rua destinada à prática da prostituição e é abordada por um homem de carro. Ela se apresenta como Tábata. Tomada pelo 
sentimento da traição e rejeição do passado, aceita a proposta e entra no carro. Em seguida, o homem começa a fazer sexo oral em Glória, mas ela não consegue manter sua ereção. A discussão se inicia, anunciando a violência que estava por vir:

Glória: Acho que não tô muito no clima.

Homem: Como assim não tá no clima?

G: Sei lá. Muita coisa na cabeça.

H: Cê não tá entendendo... Eu tô te pagando!

G: Olha, cara, eu não quero a tua grana! Foi um erro... Isso tudo aqui foi um mal entendido, eu vô ficar aqui mesmo!

$H$ : Acha que manda em alguém?! Quem manda aqui sou eu!

G: Não... Abre essa porta!

$H$ : Você acha que eu sou um viado qualquer que vem aqui pra ficar chupando o seu pau, é isso?!

G: Escuta! Abre essa porta, porra!

H: Quem que cê acha que é, caralho! Veado! Escroto! Vou te jogar lá fora e vou te encher de porrada!

[O homem abre a porta do carro, derruba Glória no chão e a agride com socos no rosto]

H: Agora eu vou te arrombar aqui na rua, você vai ver! Viado... Filha da puta!

[Glória se defende com uma máquina de choque e consegue fugir. Porém os golpes que levou na cabeça a fazem desmaiar logo em seguida]

Na tentativa de se sentir desejada sexualmente, Glória recorreu à prostituição, universo que ela própria julgava como erro e ilusão à amiga Fedra. Ela foi vítima da violência em que comumente os corpos abjetos são tratados na prostituição, já que estes são tomados para o consumo sexual, sendo, portanto, objetificados.

Quando Fedra retorna de seu teste de audição para um papel de atriz, o resultado negativo sensibiliza Glória, que a consola: “- Vida de ator é isso, né?! Tem que saber lidar com rejeição." Fedra concorda e dispara: "É... E isso a gente sabe bem, né?". De forma sutil, a película aborda a falta de oportunidade e representatividade no cinema e na teledramaturgia brasileira a atrizes trans a partir da atuação de Carol Marra, que em "A Glória e a Graça”, estreou o primeiro longa metragem na sua carreira.

Glória não deixa de pensar na situação que sua irmã está vivendo e, por isso, cede ao seu convite de almoço. Lá, ela conta a seus sobrinhos situações engraçadas e travessuras que ela e sua irmã passaram na infância. Em meio a risos, Graça chama, mais uma vez, Glória de Luís Carlos. A situação instala a curiosidade em Moreno: 
Moreno: Você tem pinto?

Graça: Moreno!

G: Tenho pinto sim. Normal, igual a você...

M: Mas você é mulher... Papoula, você não tem pinto, né?

A naturalidade da resposta que Glória emitiu diante da dúvida de Moreno revela que sua identidade de gênero não atrela-se à sua genitália e, por isso, mesmo possuindo um pênis não deixa de ser uma mulher, colaborando para a representação das diferenças de ser mulher e de corpos femininos.

A situação, no entanto, não foi encarada com naturalidade por Graça, já que ela buscou encerrar o assunto com receio de que pudesse confundir a cabeça das crianças. Receio que muitas vezes é fundamentado pelo preconceito e desinformação, acionando-se como justificativa no senso comum para a não realização do debate das questões de gênero e sexualidade ${ }^{1}$.

Em outro momento da trama, Graça revela novamente este receio ao relatar para a Glória que Moreno sempre esteve rodeado por mulheres, sem uma figura masculina por perto e, por isso, julgava importante tratá-lo como menino. Os dizeres de Graça revelam que, para ela, o que é ser menino/homem norteia-se pelo padrão biológico, pois acredita que o meio social, neste caso, familiar, pode fazê-lo transgredir à sua natureza masculina, isto é, as normas de gênero e sexualidade.

Esta questão é tratada no filme a partir da história que a protagonista escreveu quando criança.

Glória: É a história sobre uma princesa. Uma princesa linda, com cabelos vermelhos, compridos... que morava no fundo do mar. Ela tinha uma cauda igual a do seu peixinho ali, Rodrigo.

$[\ldots]$

Moreno: Por que a sereia quer quebrar o feitiço? Ser sereia é legal, tem rabo de peixe...

G: É, é legal. Viaja bastante, conhece o mundo todo, conhece o fundo do mar. Mas deve ser um pouco solitário também, né?

M: É. Por isso os homens fogem?

G: Risos. Mas o dia que ela encontrar um homem que não fuja, o feitiço se acaba imediatamente! Aí sabe o que vai acontecê? Vai aparecer um duende verde, mais ou menos assim, de meio metro de altura, com nariz bem pontudo (...) ponta de lápis, e ele vai pular na frente do sol (...) e vai correndo avisar a grande deusa. E assim que a grande deusa

\footnotetext{
${ }^{1}$ Estas situações não ocorrem somente no seio das famílias brasileiras, mas também nos próprios órgãos e espaços públicos. Quando passou a se considerar importante a discussão de gênero nas escolas não tardou para que isso passasse a ser chamado de "ideologia de gênero".
} 
souber da informação, a grande deusa transforma a sereia de uma vez por todas em uma mulher de verdade pra sempre!

$[\ldots]$

M: Tia Glória! O que acontece se a sereia não quebrar a maldição? Ela fica sereia pra sempre?

G: Ela se torna uma Medusa... Na cabeça, os cabelos dela viram cobras venenosíssimas... todos os homens que ela vê, ela vai, corre, prende numa ilha e transforma todos eles em pedra!

A travessia de gênero é descrita por Glória através da metáfora da sereia, personagem da mitologia grega. Metade humana, metade peixe, a sereia não possui genitália definida, questão que revela a não identificação de Luís Carlos quando criança com o sexo designado em seu nascimento. Tal aspecto, entretanto, não impede a sereia de exercer uma performatividade feminina e se transformar em Glória, desvinculando, assim, o sexo do gênero. Além disso, a história revela que o ser sereia/ ser travesti, ao mesmo tempo que designa o fascínio, dado o seu poder de sedução, também aponta para o medo e a aversão que esta não conformação entre sexo e gênero causa nos homens, levando-os a fugir.

Este tema é trabalhado no filme a partir da interação de Glória e Otávio (César Melo), músico que ela conheceu no prédio em que sua irmã reside. Apesar de ser evidente o flerte entre os dois, após a trama subentender que Glória contou a ele que é uma travesti, é evidenciada a hesitação de Otávio quando este anuncia que sua banda fará uma turnê de quatro meses na Europa. Glória, ao saber da notícia, percebe de imediato que a decisão dele está diretamente relacionada com a revelação que lhe fez, colocando-se, assim, como justificativa de seu afastamento.

Apesar disso, na festa preparada para Graça, Otávio aparece. Glória está vestida justamente como a sereia de sua história, com cabelos vermelhos compridos e uma saiasereia verde. A trama indica que Otávio é o único homem que não fugiu, possibilitando a ela tornar-se "uma mulher de verdade para sempre".

A trama revela que não foi só a mágoa que fez Glória ter dificuldades em aceitar o pedido de Graça, pois ela também não se imaginava no papel de mãe. É com a amiga Fedra que, mais uma vez, desabafa suas inseguranças:

Glória: A vida toda as pessoas me julgaram... Homem, mulher, viado, puta, travesti. Tudo que eu sempre quis foi ser exatamente assim, como eu sou. Isso não é pra mim. Isso não é pra mim, mesmo! 
Fedra: Por que uma travesti não pode ser mãe ${ }^{1}$

A humanização de Glória se completa. Ela é uma travesti que passou por inúmeras dificuldades na vida, humilhações, julgamentos, preconceitos, violências, solidão, mas conseguiu superar todos esses obstáculos construindo uma personalidade baseada em inúmeras qualidades: honesta, trabalhadora, próspera financeiramente, amorosa, generosa e, como ela mesmo disse, a filha que qualquer pai queria ter. Por todos esses atributos, a trama revela que a travesti Glória merece ter um amor, Otávio, e uma família, exercendo o papel de mãe de Papoula e Moreno.

\section{CONSIDERAÇÕES FINAIS}

A travestilidade não é uma temática inédita na cinematografia brasileira. Porém, se, em meados do século XX, as chanchadas brasileiras delimitavam o lugar de travestis e transexuais ao mundo teatral e carnavalesco a partir de uma reverberação cômica e festiva ${ }^{2}$, gradativamente percebe-se um deslocamento do cenário, que passa a ser 0 cotidiano social.

Ao abordar travestis e transexuais no cotidiano social, estas deixam de ser personagens destinadas à produção do "riso cruel, que humilha seus objetos" (COLLING; PIRAJÁ, 2011, p. 525) e passam a figurar pessoas com dramas, alegrias e tristezas. No entanto, a humanização nas grandes telas não retira travestis e transexuais do espaço de abjeção, uma vez que a sociedade, apesar de indicar avanços recentes no debate sobre gênero e sexualidade, ainda mantém a mesma estrutura alicerçada nas mesmas normas que regem a inteligibilidade cultural dos gêneros e a matriz heterossexual.

Tal questão se evidencia na própria metáfora da sereia na qual Glória acredita que o que fará ser "mulher de verdade" concentra-se no alcance de uma relação amorosa com um homem que a aceite, orientando-se, assim, pela heteronormatividade. Além disso, é preciso ressaltar que Glória, enquanto travesti, branca, representa uma minoria desse grupo social, já que o espaço da abjeção limita substancialmente as

1 “O que define quem pode ser mãe?" Esta é a chamada principal alocada no site construído para a divulgação da obra. Disponível em <http://agloriaeagraca.com.br/> Acesso em 01/08/2017.

${ }^{2}$ Sérgio Augusto classificou a travestilidade nas chanchadas brasileiras como "brincadeirinhas de heterossexuais" (1989, p. 184). As obras "Tererê não resolve" (1938) e "Carnaval no fogo" (1949) figuram como exemplos deste tipo de abordagem. 
possibilidades de ascensão social, fazendo com que a prostituição, por vezes, se torne o único meio possível de garantir a sobrevivência financeira, sexual, amorosa e afetiva.

O que mais incomoda no filme é, sem dúvida, o discurso da tolerância que se revela em Graça. Mesmo após ter se aproximado de Glória e compartilhado momentos bons com ela, em uma discussão Graça revela o que pensava de fato:

Graça: Você sempre quis mostrar pra todo mundo quem você é... você sempre tentou empurrar goela abaixo das pessoas esse seu jeito de ser e o papai não tinha obrigação de aceitar isso, ele não entendia, ele tinha vergonha de você, você não era o filho que ele queria ter... (choro)

A tolerância justifica-se na necessidade de Graça em procurar alguém próximo que se responsabilizasse por seus filhos, já que não podia contar com os pais dos mesmos. Por isso procurou Glória, já que, segundo a própria Graça, apesar dos pesares, "família é família". Apesar do filme humanizar a figura de travestis e transexuais e contribuir na visibilidade de outras feminilidades possíveis a partir da personagem Glória ${ }^{1}$ e também de Fedra, a obra deixa de evidenciar que "a aproximação de um padrão heterossexual não é garantia de uma convivência saudável e que o discurso da tolerância, ainda que bem intencionado, pode se traduzir em mais um mecanismo de produção da abjeção dos corpos" (COLLING; PIRAJÁ, 2001, p. 526). Por fim, a trama não consegue transformar o discurso da tolerância no necessário respeito às diferenças.

\section{REFERÊNCIAS}

AUGUSTO, Sérgio. Este mundo é um pandeiro - a chanchada de Getúlio à JK. São Paulo: Companhia das Letras, 1989.

BUTLER, Judith. Problemas de gênero. Feminismo e subversão da identidade. Rio de Janeiro: Civilização Brasileira, 2003.

COLLING, Leandro; PIRAJÁ, Tess Chamusca. Queridas, mas nem tanto: a representação da travestilidade em Queridos Amigos. In: Revista FAMECOS - mídia, cultura e tecnologia. Porto Alegre-RS, v. 18, n. 02, 2001, p. 507-528.

${ }^{1}$ A travesti, escritora e prostituta Amara Moira (2017) ressaltou que o fato da escolha de uma atriz cis fazer o papel de uma travesti no filme possui um teor político, uma vez que evidencia que "travestis são mulheres" Disponível em: <http://revistatrip.uol.com.br/tpm/a-gloria-e-a-graca-carolinaferraz-travesti-cinema-amara-moira>. Acesso em 05/08/2017. 
PELÚClO, Larissa. Na noite nem todos os gatos são pardos. Notas sobre a prostituição travesti. In: Cadernos Pagu 25, 2005, p. 217-248. 


\section{CAPÍTULO XIV}

\section{IGUALDADE DE GÊNERO: O PAPEL DOS MOVIMENTOS SOCIAIS DE IDENTIDADE}

Ilana Driele Mendes da Cunha Lima ${ }^{1}$ Ianna Dreissi Mendes da Cunha ${ }^{2}$

\footnotetext{
${ }^{1}$ Mestre em Desenvolvimento Regional. Programa de Pós-Graduação em Desenvolvimento Regional - UEPB. Bacharel em Direito. Faculdade Maurício de Nassau - FMN.

${ }^{2}$ Graduanda em Letras Língua Portuguesa. Universidade Federal de Campina Grande - UFCG. Graduanda em Direito. Faculdade Maurício de Nassau - FMN. Pesquisadora CNPq (PIBIC).
}

\section{RESUMO}

Ao longo da história as crises, sejam elas políticas ou de quaisquer ordens, serviram como estopim para mudanças sociais. Dada a atual polarização político-social brasileira, problematiza-se como tem ocorrido a atuação dos movimentos sociais de identidade em resistem às imposições conservadoras. $O$ presente estudo pretende sistematizar uma análise com relação aos movimentos sociais, com enfoque a atual conjuntura política brasileira, especificamente ao que diz respeito aos movimentos sociais de identidade. Dentre esses, os movimentos de mulheres, movimentos de homens e o movimento homossexual no brasil. Como resultado prévio, constata-se a retomada de tais movimentos em função da crise política que se instaurou no país. Conclui-se na observação da função da igualdade de gênero junto ao desenvolvimento econômico e à quebra de barreiras sociais.

Palavras-chave: Igualdade de gênero. Movimentos sociais. Movimentos sociais de identidade. Brasil.

\section{INTRODUÇÃO}

A atmosfera de crise política no Brasil tornou-se tópico de variadas discussões, dentre essas, sobre como tem afetado diversos âmbitos sociais. É sabido que, o confronto social apresenta-se na história da sociedade, mas dentro de um contexto onde predomina um sentimento disseminado de crise, vivencia-se a atuação de variados movimentos sociais que surgem além dos mais conhecidos, como os das mulheres, nesse último caso.

O imaginário social apresenta-se mais inclinado para fatores geradores da crise e, com isso, pontos podem interferir, socialmente, no modo de vida das pessoas. Essa inquietude é causada pelo surgimento cada vez mais propenso a manifestações sociais, 
visto que ao longo da história as crises, sejam elas políticas ou de quaisquer ordens, serviram como estopim para mudanças sociais. Isso é o que busca os movimentos sociais na atual conjuntura política brasileira. Os movimentos sociais perseguem a mudança do contexto político-social, nada mais promissor que uma crise, para traçar possíveis mudanças de rumos. Sobre tais apontamentos, serão utilizadas, no decorrer do artigo, as discussões realizadas por Giddens (2011).

Os movimentos sociais correspondem a reivindicações de uma associação voluntária de pessoas, a fim de se obter melhorias para os seus membros, promover ou ir de encontro a mudanças na ordem social vigente. Alain Touraine define os movimentos sociais como sendo uma ação conflitante de agentes das classes sociais, lutando pelo controle do sistema de ação histórica (TAURAINE apud GHANEM, 1989). Existem diversos tipos de movimentos sociais, a saber: Migratórios, Revolucionários, Expressivos, Utópicos, Reformistas, de Resistência, dentre outras tipificações.

Os movimentos sociais possuem características ou princípios em comum, que os classificam segundo seus objetivos. São três os princípios que definem os movimentos sociais. O Princípio da Identidade seria a auto definição do ator como membro de determinada classe de pessoas, ou seja, o ator que o movimento defende. No entanto, esse princípio não se confunde com os "movimentos sociais de identidade", que serão aqui estudados. O Princípio da Identidade se encontra em todos os movimentos sociais, isto porque o indivíduo tem que definir-se como pertencente àquela classe de pessoas, independentemente do tipo de reivindicação ou mudança que almeja. Enquanto que, os movimentos sociais de identidade correspondem a um movimento específico que se norteia a partir de definições da identidade do indivíduo, e suas pautas partem dessa premissa.

Por fim, o segundo e o terceiro princípio. O Princípio da Oposição seria a definição ao que se opõe a nomeação de um adversário ou algo que quer ser combatido. E já o Princípio da Totalidade representa que um movimento social defende o interesse de todos que compõem aquela classe social, não importando se aqueles não aderem ao movimento, ambos serão beneficiados, segundo o que se busca no movimento.

Frente $a$ isso, o presente estudo pretende sistematizar uma análise dos movimentos sociais na atual conjuntura política brasileira, especificamente os movimentos sociais de identidade. Tendo em vista a retomada desses movimentos em 
função da crise política que se instaurou no país, junto com uma crescente onda de conservadorismo, o que proporcionou uma chamada polarização política e social, dando força aos movimentos sociais de identidade que resistem às imposições conservadoras.

\section{REVISÃO BIBLIOGRÁFICA}

\subsection{Uma nova ação social estratégica: movimentos sociais de identidade}

Como dito anteriormente, os movimentos sociais constituem em uma interação de pessoas que se identificam com uma causa em comum, tem o mesmo opositor e possuem as mesmas pretensões. Buscam modificar a ordem existente, e o fazem através de reivindicações, propondo mudanças ou resistindo a essas. Os movimentos sociais sempre existiram ao longo da história, propondo modificações significativas, especialmente em momentos de crises.

Com respeito aos movimentos sociais de identidade, estes são conhecidos como sendo movimentos que propõem modificações na ordem social em benefício de um determinado grupo de pessoas que possuem como característica essencial a sua identidade, ou seja, a forma como o indivíduo se define na sociedade, pode ser raça, etnia, nacionalidade, cor ou gênero. Iremos nos ater aos movimentos basicamente relacionados aos conceitos de gênero, sendo este, um termo cultural que se refere aos papéis distintos que a sociedade impõe a homens e mulheres (HEYWOOD, 2010).

O gênero está ligado a fatores socialmente construídos de masculinidade e feminilidade, que não são diretamente ligados apenas ao sexo biológico. Segundo os sociólogos, o gênero do indivíduo não pode ser definido com tamanha facilidade, eles utilizam o termo sexo apenas para referenciar as diferenças anatômicas e fisiológicas dos indivíduos (GIDDENS, 2011). Corroborando com este entendimento, tem-se a afirmação da antropóloga Aurelia Martín Casares: “[...] el género es una categoria de análisis científico que se refiere a las cualidades culturales y sociales que se asocian simbólicamente a las personas según las formas de concebirlas identidades genéricas (de género) en cada sociedad..." (CASARES apud OLIVEIRA, 2013, p. 27).

Portanto, os movimentos sociais de identidade que surgem a partir de conflitos identitários não são discussões atuais nem tão poucos exclusivos de nossa época. Como 
se pôde verificar, por exemplo, durante a diáspora do povo judeu no antigo Egito, e dos europeus que migraram para o Novo Mundo, para os nativos que se foram colonizados.

\section{2 "Feminismos" e movimento de mulheres}

Um tema bastante recorrente em variadas discussões é a relação entre o que seria feminismo e Movimento de Mulheres. Para alguns estudiosos, esses espaços são distintos, o feminismo seria, antes de tudo, um movimento de mulheres, pois foi criado para e por mulheres, mas nem todo movimento de mulheres se denomina feminista. Isto porque, existe muito desconhecimento e oposição dentro do próprio movimento de mulheres sobre o que seria feminismo, por questões políticas, muitas mulheres se opõem ao feminismo. Portanto, "tende-se a considerar o feminismo como parte do movimento de mulheres, mas não como sendo a mesma coisa. São feministas aquelas mulheres e organizações que se definam assim" (SILVA; CAMURÇA, 2010, p.16). Assinalam ainda que

Para lutar contra a desigualdade de gênero, contra a exploração e opressão das mulheres, o movimento de mulheres colhe os princípios organizativos, a teoria explicativa da sociedade e o projeto político formulados a partir do feminismo. Quando se apropriam destes elementos, os movimentos de mulheres passam a usá-los criticamente e com isto constroem e transformam continuadamente seu próprio movimento, contribuem com novas reflexões e novas experiências a partir das quais novas pautas de lutas são instituídas, enriquecendo o próprio feminismo. É por isto mesmo que há quem pense que todo movimento de mulheres é feminista, uma vez que as mulheres fazem luta por direitos para as mulheres. Entretanto, nem todas as organizações do movimento de mulheres definem-se como parte do movimento feminista. Sabemos que há mulheres em todos os movimentos sociais, mas nem todos os movimentos sociais enfrentam os problemas da situação das mulheres. Também nem todas as mulheres refletem sobre a situação de dominação e exploração que nós vivemos. Por isto, nem todas apoiam as causas feministas (SILVA; CAMURÇA, 2010, p. 15-16).

Feminismo, para a feminista e ativista, Pearl Cleage, seria "a crença de que as mulheres são seres humanos plenos, capazes de participação e liderança em toda a gama de atividades humanas - intelectuais, políticas, sociais, sexuais, espirituais e econômicas" (COLLINS, 2017). O livro "A Cidade das Mulheres" de Christine de Pisan, publicado na Itália, prenunciou as ideias do feminismo defendendo o direito de 
educação e participação política das mulheres, apesar de que um movimento organizado apenas foi ser estabelecido em meados do século XIX, com o trabalho de Mary Wollstonecraft, inaugurando o feminismo moderno (HEYWOOD, 2010).

No contexto da revolução francesa surge "a primeira onda" do feminismo, momento de revolução propício para modificações na ordem pré-estabelecida. Essa primeira onda defendia e reclamava por mais direitos políticos para as mulheres. 0 sufrágio feminino era a primeira reivindicação desse grupo, acreditava-se que se a mulher participasse mais da política as diferenças sociais suportadas pelas mulheres logo também desapareceriam. O movimento era em sua maioria composto por mulheres casadas, brancas e de classe média.

Nos Estados Unidos puderam-se observar mais um cenário de crise política em que um movimento ganhou força e notoriedade, visto que em 1840, inspirados pela campanha contra a escravatura, o movimento feminino atuou na convenção de Seneca Falls, momento posterior, com a adoção da declaração de sentimentos de Elizabeth Cady Stanton, se exigiu o sufrágio feminino. No Reino Unido, uma proposta de John Stuart Mill, sobre a inclusão do sufrágio feminino, foi rejeitada em 1850. Esse fato deu início a um forte movimento sufragista conhecido como as suffragettes, a partir da formação da União Social e Política das Mulheres proposto pela filha de Christabel, Emmeline Pankhurst.

A primeira onda do feminismo terminou com a aprovação do sufrágio feminino na Nova Zelândia em 1893, nos EUA em 1920, parcialmente no Reino Unido em 1918 (apenas dez anos depois seria o sufrágio igual para homens e mulheres).

Em 1960 surge a chamada "segunda onda" do feminismo, reconhecendo que os direitos políticos femininos conquistados a partir das revoluções da primeira onda do feminismo foram importantes, mas não o suficiente para combater o mal sem nome que acometia diariamente as mulheres, que estavam confina das em seus lares para servirem sem muitos direitos e sem muitas opções de escolha.

O livro “Mística Feminina”, de Betty Friedan, em 1963, contribuiu para o estopim e avanço da segunda onda do movimento feminino. A questão das mulheres passou a ser um tema de cunho político, visto o teor das publicações que seguiam. O livro de Kate Millet, "Política Sexual" e de Germaine Greer, "A mulher eunuco" propõe discussões 
mais profundas sobre a questão da opressão feminina em seus aspectos políticos, sexuais e psicológicos.

A segunda onda do feminismo no Brasil coincidiu com um momento de forte instabilidade política, pois se deu durante o período de ditadura militar. Ao mesmo tempo em que foi um momento promissor para manifestações e revoluções contra a política daquela época, não foi um momento sensível aos direitos humanos das pessoas envolvidas, para o movimento feminista não o foi diferente. Apesar de haver distinções dentro do movimento feminista (Radical, Liberal, Negro, Marxista-Socialista) conforme iremos expor posteriormente, o movimento feminista era visto como outros movimentos, nocivo ao Estado. Isso fez com que as mulheres feministas brasileiras assumissem uma postura diferenciada em relação às outras mulheres no âmbito internacional. Muitas delas eram militantes de esquerda concomitantemente ao movimento feminista, o que às levou ao exílio ou morte (BRYM, LIE et al, 2006).

No processo de redemocratização brasileiro, o movimento feminista teve importante participação, o que o denominou de um feminismo muito mais incomodado com as questões sociais que os do resto do mundo (SORJ apud BRYM, LIE et al, 2006).

Alguns estudiosos afirmam que foram apenas essas duas ondas que caracterizaram o movimento feminista e que este já alcançou seu auge e esgotou suas demandas, ao trazer o termo pós-feminismo para as discussões que envolvem alguma pauta feminista. A popularização da ideia do pós-feminismo não retira do campo de estudos os movimentos feministas atuais, visto que, em contrapartida muitos estudiosos acreditam que o termo correto seria terceira onda do feminismo (GAMBLE apud BRYM, LIE et al, 2006).

Apesar dessa inquietação por parte dos estudiosos, o movimento feminista ainda se mostra atuante com base nas pautas que surgiram no presente século com respeito aos direitos e proteção da mulher em relação a prostituição, a pornografia, a violência, a censura, o aborto, a maternidade, raça, etnia, estado do bem estar social, entre outros.

O feminismo é um movimento social que analisa e critica o mundo e a situação das mulheres. Critica incisivamente a desigualdade e denuncia as injustiças da sociedade patriarcal (SILVIA; CAMURÇA, 2013). O patriarcado, segundo as feministas, se refere a um processo sistemático, institucionalizado e difundido de opressão de gênero que é a base para diversas outras injustiças. A obra de Eva Figes, "Posturas Patriarcais", em 1970 
chamou a atenção para as desvantagens sociais e legais originadas do patriarcado, através de crenças e valores que subjugam a mulher e a coloca em situação de subordinação em relação ao homem que convive, seja pai, irmão ou marido/companheiro. Essas crenças impregnam a cultura, filosofia, moralidade e religião da sociedade em todas as esferas (HEYWOOD, 2010).

O patriarcado, segundo Kate Millett, em Política Sexual (1970), seria uma "constante social" capaz de nortear toda a estrutura da sociedade no âmbito político, econômico e social. Segundo ela, seria "a metade da população feminina controlada pela outra metade masculina". Em seu livro, ela propôs que, o patriarcado deveria ser questionado, o que seria o "despertar da consciência", desafiar a inferioridade cultural por meio do amor próprio, autoestima e autoafirmação (HEYWOOD, 2010).

A autora questionou também o que seria esfera pública ou privada, visto que a política somente se interessa por aquilo que se encontra no âmbito público, e muitas das pautas feministas se encontravam dentro de âmbitos privados, familiar, doméstico. Segundo ela, política seria "relações estruturadas de poder, acordos por meio dos quais um grupo de pessoas é controlado por outro", logo, questionar a subserviência feminina era algo político. A divisão sexual do trabalho havia sido considerada natural e não política, o que deixou o ambiente propício para que as feministas discutissem inclusive o que é político ou natural, público ou privado. Apesar de que por muito tempo acreditava-se que a questão da igualdade sexual era assunto da esfera privada, por isso não carecia de muita importância (HEYWOOD, 2010).

O feminismo é um movimento que foi se fragmentando e apresentando diversas correntes, o qual apesar de defender os interesses femininos possui algumas diferenças ideológicas. Importa estudar essas correntes para compreender o que, apesar da fragmentação ideológica, as correntes representaram à época em que se proliferaram.

Influenciado pelas ideias do liberalismo, o feminismo liberal foi a primeira corrente do movimento, na primeira onda do feminismo, no final do século XVIII. A obra mais influente dessa corrente feminista foi o trabalho de Mary Wollstonecraft, a qual reivindica os mesmos direitos e privilégios dos homens, afirmando que as mulheres também eram seres humanos e que a distinção entre os sexos era irrelevante para a vida social e política. 
Durante a segunda onda o feminismo liberal passou a questionar "o mal sem nome", ou seja, a obrigação imposta às mulheres na reclusão ao âmbito doméstico. Nesse período, Betty Friedan ajudou a fundar a National Organization of Women (NOW) que se transformou em uma das organizações de mulheres mais forte do mundo.

O feminismo liberal exige os direitos iguais para homens e mulheres. Uma corrente essencialmente reformista, que não se preocupa essencialmente com as pressões sociais do patriarcado, mais almeja um cenário de igualdade competitiva entre homens e mulheres, não desejam modificar o que se intende como público e privado, que é uma das preocupações das feministas em geral. Algumas questões importantes para o exercício desses direitos não constaram em suas pautas, como a divisão sexual do trabalho doméstico e à distribuição de poder dentro da família.

No Reino Unido, modificações legislativas, como o Equal Pay Act (1970) e o Sex Discriminition (1975), objetivaram salvaguardar a igualdade legislativa e combater a discriminação sexista, e contaram com o apoio e a atuação das feministas liberais. Essencialmente reformista, as liberais não se preocupam em derrubar o sistema existente, por isso são consideradas mais moderadas em seus objetivos e métodos (GIDDENS, 2011). Segundo o sociólogo britânico, Anthony Giddens:

Embora as feministas liberais tenham contribuído muito para o avanço das mulheres no último século, os críticos argumentam que elas não conseguiram lidar com as raízes da desigualdade de gênero e não reconhecem a natureza sistêmica da opressão das mulheres na sociedade. Ao focalizar separadamente as privações que as mulheres sofrem - sexismo, discriminação, o "teto de vidro" - as feministas liberais pitam apenas um quadro parcial da desigualdade de gênero. (GIDDENS, 2011, p.442)

Em "A Segunda Etapa", Friedan dedicou-se a discutir o problema da mulher em conciliar vida social e política, como, o trabalho externo com o trabalho doméstico, "o amor e os filhos"; por ser algo natural, a mulher deveria saber conciliar os dois. Verificase que a preocupação desse movimento estava na obtenção de uma vida pública para as mulheres, mesmo que ensejasse um acúmulo de tarefas.

Contrário ao feminismo liberal, o feminismo socialista só se tornou importante na segunda metade do século XX. Como ideal, dedicou-se a análise de que o patriarcado só pode ser entendido a partir de fatores socioeconômicos, onde a emancipação, em 
especial, a das mulheres, que tanto o movimento feminista buscava, só seria possível através de uma revolução social, em que o capitalismo seria derrubado; sendo essa emancipação um subproduto desta revolução.

A "luta de classes" deveria se sobressair à "guerra dos sexos" concentrando a energia das mulheres e do feminismo apenas ao movimento trabalhista, e não ao feminista fragmentado, isolado e desagregador, segundo eles. Apesar de algumas feministas marxistas modernas não analisarem a posição da mulher apenas em termos meramente econômicos, mas também, sociais, políticas e culturais da sociedade; o aspecto econômico ainda predomina nessa vertente.

Isso porque, segundo o feminismo socialista e marxista nada pode interferir nas diferenças entre os sexos e garantir uma verdadeira emancipação às mulheres, a não ser uma revolução social, devido a essas diferenças terem suas origens na própria estrutura socioeconômica. De acordo com isso, o confinamento das mulheres nos lares e sua dedicação exclusiva aos trabalhos domésticos e aos filhos serviriam aos interesses econômicos do capitalismo, servindo apenas como um "exército de reserva" para que sejam recrutadas em caso que se precise aumentar a produção, facilmente dispensadas durante crises econômicas sem que seja um fardo ao empregador e ao Estado (HEYWOOD, 2010).

A ideia central do feminismo socialista foi exposta na obra de Friederich Engels em "A origem da família, da propriedade privada e do Estado", de 1884. O autor fundamentou que a posição da mulher foi drasticamente alterada após a ascensão e desenvolvimento do capitalismo e da propriedade privada. Segundo ele, nas sociedades pré-capitalistas se sobressaía o direito materno, tanto a herança da propriedade e da posição social dava-se por meio da ascendência feminina, e com o advento do capitalismo o direito materno foi abolido, e os homens passaram a deter à posse da propriedade privada, sendo o que chamou Engels de "a grande derrota histórica do sexo feminino" (HEYWOOD, 2010, p.35).

Essa vertente encontra críticas exatamente pela forma cultural que se manifesta a opressão suportada pelas mulheres. Segundo ressalta Andrew Heywood, Juliet Mitchell, em 1971, afirmou que na sociedade as mulheres têm quatro funções culturalmente impostas: 1) integram a força de trabalho e são ativas na produção (principalmente no âmbito doméstico, mas se trabalhar externamente acumulará com 
o doméstico na maioria dos casos); 2) geram filhos, reproduzindo a espécie humana; 3) são responsáveis pela educação, socialização e criação dos mesmos; 4) são objetos sexuais. Portanto, segundo Mitchell, a emancipação e libertação da mulher deve se dá em todas essas áreas, não apenas através da derrubada do capitalismo, que pode influenciar, mas não é o único causador. Como também, conforme salienta Giddens, para Engels, o capitalismo não explora somente as mulheres, mas explora também os homens com baixos salários, e as mulheres com salário nenhum (GIDDENS, 2011).

Outra corrente do movimento feminista é o feminismo radical. As feministas radicais concentram-se na "família" como uma das principais fontes de opressão das mulheres na sociedade, voltando-se ao patriarcado para explicar a desigualdade dos gêneros. As principais pautas dão ênfase à violência masculina e a objetificação das mulheres, para, assim, discutir a opressão suportada por essas (GIDDENS, 2011).

A ideia central do feminismo radical é dedicar-se a revelar como o patriarcado influencia não só na política e na economia, mas na vida pública e em todos os aspectos da existência feminina social, pessoal e sexual. Contrárias às correntes socialistas e liberais, pois nenhuma delas evidenciou que o gênero é a mais fundamental de todas as divisões sociais, as radicais ressaltaram esse aspecto, restando evidenciado nas obras das feministas: Simone de Beauvoir, Germaine Greer e Kate Millett.

O feminismo radical coloca o homem apenas como opressor e todas as relações com este devem ser abolidas, ao contrário das outras vertentes, a socialista pautam 0 homem como mais uma vítima do capitalismo e a liberal desconsidera essa opressão e aceita os papeis culturalmente impostos, mesmo que reivindiquem seus direitos. 0 Feminismo radical prega uma revolução sexual, e não social como as socialistas. Como exemplo disso, teve a posição pró-mulher na França e nos Estados Unidos, ressaltando a "maternidade e a fertilidade". Ideias centrais do chamado eco feminismo (HEYWOOD, 2010).

O feminismo não comportou os questionamentos de todas as mulheres, como nas questões referentes à raça. Enquanto o liberal atendeu a necessidade das reivindicações de mulheres brancas, casadas, de classe média, o socialista focalizou o interesse das reivindicações classistas e não à vertente pautada a causa das mulheres negras. 
O termo "negro" acrescenta ao movimento feminista as pautas específicas para as mulheres negras. $O$ feminismo negro tem por ideia central analisar a opressão sobre as mulheres negras e como o racismo institucionalizado opera de maneira agravada pelo gênero, buscando fornecer uma perspectiva mais completa de como a opressão de gênero trabalha em conjunto com a opressão racial para mulheres e homens negros.

Acima das questões feministas está a questão racial para as mulheres negras, como por exemplo, a solidariedade e irmandade. "Dentro das comunidades afroamericanas, uma regra é que as mulheres negras apoiarão os homens negros, em qualquer circunstância (COLLINS, 2017, P.15)", diferentemente de outras vertentes, como a do feminismo radical, que não se apoiaria em um homem em nenhuma circunstância. As feministas negras argumentam que não se pode generalizar teorias de como as mulheres são subordinadas e oprimidas, como se todas as mulheres sofressem do mesmo modo. A forma de opressão, sua intensidade e modo são questionados por essa vertente, unificar a forma de opressão de gênero é problemático.

A autora Bell Hooks (2019), ressalta um diferencial das mulheres feministas negras, segundo a autora, elas detinham a capacidade de se articular e de se expressar melhor. Contribuição da política difundida e ensinada nas famílias negras do sul, de que as mulheres fossem mais articuladas, as quais eram ensinadas a sempre ficar em pé e falar de forma clara.

Segundo a autora, novamente se encontra divisão entre o feminismo negro e as outras vertentes, em relação ao argumento de que o patriarcado (família) seria a causa da opressão das mulheres. Para as feministas negras a família representava um dos pontos de solidariedade contra o racismo (GIDDENS, 2011). A violência de gênero sofrida pelas mulheres negras poderia ser encontrada em diferentes locais, em que o patriarcado poderia ter sua participação, quando a violência era encontrada fora de seus lares, o patriarcado aprendido pelo "branco" era refletido na ocasião de violência.

Diante disso, qualquer teoria que busque a igualdade de gênero para mulheres negras necessita levar em conta o racismo, para que busque explicar a opressão dessas mulheres de forma adequada. A teoria feminista negra tem o seu foco nas relações entre raça, classe e gênero, pois as mulheres negras têm muitas desvantagens tanto em relação a preconceitos que sofrem com relação à raça, como quanto ao sexo e a posição 
hierárquica na sociedade. Quando se relacionam, esses fatores se intensificam reforçando desvantagens.

Têm-se também as feministas pós-modernas, ou pós-estruturalistas, discordam do feminismo cultural, e da teoria da existência de diferenças essenciais entre homens e mulheres (HEYWOOD, 2010). Questiona, sobretudo, o termo "mulher", ao rejeitar a teoria que afirma explicar a posição das mulheres na sociedade, ou que defina a essência do "ser mulher" ou uma categoria única e universal de "mulher" (GIDDENS, 2011). Tentam criar termos mais fluídos e abertos.

Dentre os tipos de movimentos feministas, o pós-moderno é a que mais agrega experiências diversas, como, as de homossexuais, heterossexuais, mulheres negras, mulheres da classe operária, etc. Não aceitam que o patriarcado, a raça, ou a classe social sejam os únicos fatores causadores dessa desigualdade, mas que diversos fatores estruturais; os quais devem ser desconstruídos. Feministas como Simone de Beauvoir (1949) evidenciaram em suas obras essa teoria, como se verifica em célebre frase de Beauvoir: “Ninguém nasce Mulher, torna-se!” (BEAUVOIR, 1986, p. 29).

\subsection{Movimentos de homens}

Outro movimento social identitário que busca reagir, legitimar e reclamar sua identidade é o movimento de homens. Ainda pouco difundido, mas que existe de fato. O movimento de homens heterossexuais busca analisar as influências do patriarcado para a vida do homem. Teve início não organizado por meio de movimentos ou grupos em salas de discussões no Brasil, em 1994, no Recife, e na Espanha, em 2003, em Barcelona, fomentando a criação de grupos de homens igualitários (OLIVEIRA, 2013).

O grupo busca(va) por produção científica para a ampliação do entendimento acerca da construção e da identidade genérica do homem, nas quais confrontavam ideias deterministas e construcionistas de mudança possível ou impossível dos modelos identitários. Adotando a posição de que o termo "homem", assim como, o termo "mulher", faz parte de uma construção social, e que "o homem não nasce homem, ele se torna homem" (BADINTER apud OLIVEIRA, 2013, p.26).

A identidade corresponde a identificar-se com um conjunto de características femininas e masculinas, que se relacionam no indivíduo, coexistindo. Embora que, de forma predominante, essa identidade apresenta-se como fruto de uma construção 
social, em que os interesses da sociedade determinam os papéis que serão desempenhados por cada um, homem ou mulher. O que possui o intuito de cobrar e obrigar coercitivamente que os indivíduos modem seus comportamentos à suas culturas, costumes e crenças (BOURDIEU apud OLIVEIRA, 2013, p. 29).

Comportamentos baseados na cultura, costumes e crenças podem obrigar padrões inatingíveis não só a mulheres, mas também aos homens. $O$ papel do homem provedor, o "Dom Juan", o que tem que ser forte em todas as situações, etc; são papéis impostos aos homens, os quais nem sempre são fáceis de executar, e caso essas características faltem a um homem, este sofrerá sanções sociais.

O trabalho do grupo visa(va) compreender se seria possível ou não a mudança nas relações de gênero, em meio a condição de dominância de um no outro. Conforme a teoria da mudança impossível, a dominância masculina é universal. Além disso, a mudança seria impossível devido a essa condição ser decorrente do determinismo social e cultural, não levando em consideração aspectos individuais.

O sociólogo Pierre Bourdieu, em seu livro “A Dominação Masculina” (1999), afirma que pelo fato da dominação masculina ser universal, transcultural, presente em todas as culturas, ela seria exonerável. Essa dominação se perpetuaria porque os próprios dominados legitimam a dominação através de agentes mantenedores dessa estrutura e ideologia social, são exemplos deles: a família, a escola, o Estado e as religiões. Gutmann acrescenta que essa forma de dominação é um essencialismo e, entre todas, seria a mais difícil de erradicar (GUTMANN apud OLIVEIRA, 2013).

Tais argumentos apresentam certa correlação com ideais deterministas, ao trazer um sentido de imutabilidade da dominação masculina em que o indivíduo não poderia mudar sua realidade, e que, embora tentasse, estaria fadado a sucumbir às pressões sociais. Todavia, verifica-se que mesmo a modificação sendo difícil, essa não é impossível. Primeiramente, sabe-se que, homem e mulher não são opostos como o feminino é do masculino, se assim o fosse, a mulher seria o oposto de "humano", como afirmava Aristóteles, o que é inconcebível. Essa e outras teorias da imutabilidade abrem espaço para críticas e para crer em uma mudança possível.

$\mathrm{Na}$ teoria da mudança possível, a autora Simone de Beauvoir defende a ideia de uma educação voltada para a igualdade entre os sexos. Em seu livro "O Segundo Sexo" (1949), a autora trata o assunto de uma forma mais política. Opondo-se a Pierre 
Bourdieu, a autora defende que os agentes mantenedores somente reproduzem o que é ditado pela sociedade, e que consequentemente os agentes terão que mudar. Apesar de sua obra enfatizar a questão da mulher, o grupo de discussão de homens estuda seus escritos, pois esses se referem à construção identitária e de gênero que afeta também os homens. Conforme citado acima, a autora tem um trabalho mais amplo, voltado a abranger mais grupos.

Contudo, autora do livro "XY: a identidade masculina" (1993), Bandinter, retoma a discussão sobre gênero com foco na construção genérica do homem, mostrando como seria ser "homem de verdade" ao longo da história. A autora questiona aspectos da concepção binária aristotélica dos ditos "traços femininos" (sensibilidade, afetividade, pacificidade...), que nos homens seria considerado como uma conduta anormal, passível de punições psicológicas e/ou físicas (OLIVEIRA, 2013).

O movimento de homens, assim como os de mulheres, procura igualdade entre os gêneros, onde o homem não seja forçado a torna-se um personagem da sociedade, e a família seja mais simétrica, com escolhas pessoais respeitadas. Heywood adverte que se os homens jovens assim não enxergarem essas mudanças sociais correm o risco de cair numa cultura de inação (HEYWOOD, 2010), onde o "homem provedor" não será mais necessário em um lar e os mesmos terão de se readaptar tardiamente.

Contudo, conforme se verifica no rol das conquistas advindas dos movimentos anteriores, como o do feminismo, a mudança social em prol dos homens para uma igualdade dos gêneros é possível. O feminismo conquistou vários direitos para as mulheres, assim contribuindo para modificações sociais; o que movimento dos homes também poderá assim o fazer.

\subsection{Movimento homossexual brasileiro}

O movimento homossexual no Brasil, no âmbito político, se iniciou a partir da década de 70, antes disso, em meados da década de 50, já haviam organizações, discussões e reuniões em torno da temática. Os jornais, como o "Snob" (1963-1969) e a Associação Brasileira de Impressa Gay (1967-1968), fizeram parte do início do movimento, como forma mais definida de um projeto de politização da questão homossexual. Essa primeira movimentação surge como a: "primeira onda do movimento homossexual brasileiro". 
Na Argentina um movimento parecido se instaurou no ano de 1969, Nuestro Mundo, e em 1971, Frente de Liberação Homossexual Argentina. No mesmo período, deram início a movimentos no México e em Porto Rico, como no Brasil, influenciados pelos movimentos nos Estados Unidos e na Europa Ocidental moldadas para as políticas atuais de seus países (FACCHINI, 2005).

No cenário político de uma ditadura militar, o movimento homossexual brasileiro visava driblar a censura governamental que permeava os movimentos de jovens e estudantes dos anos 60. Além de, analisar a cultura homossexual, papéis de gênero, e a sexualidade de forma mais específica e completa. Apesar das repressões militares, 0 movimento ainda conseguiu algumas publicações e, com isso, surgiram caminhos para uma organização política homossexual. Importa destacar que, a ditadura militar teve um papel fundamental para o movimento homossexual brasileiro, conforme se verifica nos escritos da socióloga Regina Facchini:

Em vez de identificar apenas um efeito negativo da ditadura militar na possibilidade de organização de um movimento homossexual, é importante, por exemplo, notar o quanto a ditadura estimulou a formação de resistências em diversos setores sociais e como ela pode ter sido, inclusive, responsável pelo perfil fortemente antiautoritário que marcou a "primeira onda" do movimento homossexual brasileiro (FACCHINI, 2005, p. 93).

Segundo a autora, a ditadura pode ter sido responsável pelo "boom" do movimento homossexual brasileiro, e demarcado sensivelmente a atuação e trajetória individuais e os modos de atuação dos primeiros militantes homossexuais. Ainda segundo a socióloga, o primeiro grupo de atuação política homossexual foi o grupo SOMOS, em São Paulo, no período de 1978. Era inicialmente formado apenas por homens, e adotava provisoriamente o nome de: Núcleo de Ação pelos Direitos dos Homossexuais. Esse grupo teve sua primeira aparição pública por meio de uma carta endereçada ao Sindicato dos Jornalistas, sendo, em 1978, batizado de SOMOS (FACCHINI, 2005).

Dividindo-se posteriormente em Eros e Libertos, o grupo permitiu a entrada de novos integrantes, inclusive mulheres. Através de uma polarização entre "esquerda" e "autonomia das minorias", o que foi responsável por conflitos internos no grupo, os militantes acabaram por defender uma estratégia de transformação social de aliança 
com outras minorias, como com os trabalhadores e grupos de esquerda (FACCHINI, 2005). O objetivo do grupo SOMOS era de: "apreender as violências e discriminações específicas nas trajetórias individuais, (...) que giravam em torno dos depoimentos. A ideia do grupo era discutir sexualidade a partir das vivências de seus integrantes, na tentativa de se construir uma identidade coletiva" (OLIVEIRA, 2010, p. 5).

O jornal Lampião (1978), durante a primeira onda, foi utilizado para reforçar a ideia de pertencimento, adotando jargões do tipo "bicha" e "veado" para desconstruir a pejoratividade do termo. Durante a segunda onda do movimento, o Triângulo Rosa tinha a dinâmica de reuniões e atuação do grupo SOMOS se restringiu e saiu do cenário político, mantendo as reuniões com mero caráter de terapia. Na segunda onda, a política era institucional, com atuação junto ao Legislativo e Judiciário, em que a identidade individual homossexual estava pouco em pauta e a importância era dada a visibilidade homossexual, o homossexual "respeitável" (OLIVEIRA, 2010).

Com a eclosão do HIV/AIDS, em meados da década de 1980, a sexualidade e homossexualidade estavam no centro dos debates públicos, movimentos como o Triângulo Rosa atuou na tentativa de afastar as ligações do homossexualismo com as doenças, com a intenção de buscar aceitação através de demonstrar a ideia do homossexual respeitável.

O movimento passou a denominar-se movimento LGBT apartir de 1990, e passou a incluir Lésbicas, Gays, Bissexuais, Travestis, Transexuais ou Transgêneros. Visto que, o termo Gay não conseguia abranger todas as categorias. ${ }^{1}$

Atualmente, os movimentos homossexuais encontram-se mais incluídos nas questões políticas, sob nova estrutura social, atuando diretamente na política em busca de melhorias na vida de seus atores. Como também, tem-se atuado através de ongs, da mídia, com outros movimentos sociais, diálogo com redes internacionais de direitos humanos, e discussão direta com os agentes públicos em resposta à instituições sociais, como as religiosas. Além de eventos públicos que demarcam a trajetória e dá visibilidade ao movimento, como as paradas e o dia do Orgulho Gay.

${ }^{1}$ Algumas variantes: LGBTQ, " $Q$ " de queer para aqueles que questionam sua identidade sexual; E para incluir pessoas intersexuais: LGBTIQ ou LGBTQI+; Adicionam a letra "A" para os assexuais ou simpatizantes: LGBTQIA; par quem não se encaixa em nenhuma ou em todas as siglas: LGBTQIA+. 


\section{CONSIDERAÇÕES FINAIS}

Os movimentos sociais são impulsionados diante do cenário político que a sociedade vivencia. Foi assim durante a ditadura militar que impulsionou e alavancou 0 movimento homossexual no Brasil, em que, nesse momento histórico, o movimento conseguiu ter força para reivindicar os seus direitos e melhorias para seus membros, além de se unir em prol de outras minorias. De modo semelhante fizeram também as mulheres feministas, muitas eram ativistas de outras causas e se identificavam com a política de esquerda, atuando contra o regime de forma direta. Como dito no presente estudo, o feminismo no Brasil durante a ditadura corroborou com ideais democráticos e revolucionários, contribuindo como o resgate da democracia no país.

Apesar de diversos, os movimentos sociais identitários focam em uma ideia central comum: A busca por igualdade efetiva e plena para todos os gêneros, independente de como se identificam os indivíduos. As mulheres, algumas feministas e outras que assim não se denominam, buscaram desde o século XIX melhorias em sua condição, mais direitos gradativamente. O movimento feminista fragmentou-se, se transformou e se dividiu em pautas e vertentes ideológicas diferentes, contudo, a ideia central do movimento não foi modificada, a busca por igualdade entre os gêneros.

Atualmente ao redor do mundo, o feminismo atua de diversas formas. Em algumas partes do mundo, vincular-se a esse movimento significa agir contra a pobreza extrema e mudar atitudes masculinas tradicionais e prejudiciais que favorecem famílias contrárias à contracepção, por exemplo. Em alguns locais, o feminismo atua fazendo campanhas por melhores direitos trabalhistas para as mulheres, pela igualdade no emprego, a provisão e o cuidado dos filhos, além do fim da violência contra as mulheres.

Historicamente, o feminismo buscou analisar as desigualdades persistentes de gênero, propondo agendas para superá-las. O feminismo corroborou com revoluções e com a política na sociedade de diversas formas, contudo, existem novas formas de atuação e novas pautas do feminismo no século XXI para modificar a situação da política atual.

Em geral, a desigualdade de gênero existe em praticamente todos os países, independente de sua economia e política, mesmo que estando em maior parte nos países subdesenvolvidos. As mulheres enfrentam a desigualdade, sobretudo, na esfera 
econômica, pois algumas, por exemplo, só podem trabalhar se contratarem empregadas domésticas para cuidarem dos seus filhos devido à inexistência de locais aptos para esses ficarem. A busca pelo aumento do número e melhorias nas creches é uma das pautas políticas feministas atuais, enquanto buscam impulsionar estudos em perspectiva de gênero que promovam, ainda que em longo prazo, a possibilidade de famílias mais simétricas, onde os pais e as mães têm iguais divisões de tarefas em relação à provisão e cuidado dos filhos.

Desse modo, observa-se que a igualdade de gênero segue sendo função para o desenvolvimento econômico. Em face de exemplificação, os 11 primeiros países que lideram o ranking de Medida de Empoderamento de Gênero são ricos, enquanto os níveis mais baixos estão em países da África Subsaariana.

Segundo dados levantados na Plataforma de Política Feminista, o movimento tem atuado em diferentes temas, como por exemplo: democracia política e social; desigualdades socioeconômicas; questões agrária, urbana, ambiental, racial e étnica; trabalho das mulheres e trabalho doméstico; liberdade sexual e reprodutiva. 0 movimento feminista e o movimento homossexual têm atuado em conjunto com algumas pautas como: a liberdade sexual e reprodutiva, direitos civis e sociais de lésbicas, gays, travestis, transexuais, bissexuais e transgêneros (BRYM, LIE, et al, 2006).

Os grupos de homens também atuam em conjunto com os outros movimentos. Uma campanha denominada "He for She" (Eles por Elas), da ONU, envolve homens na busca pela igualdade de gênero. Sobre esse: “o movimento Eles Por Elas (He For She) é um esforço global para envolver homens e meninos na remoção das barreiras sociais e culturais que impedem as mulheres de atingir seu potencial, e ajudar homens e mulheres a modelarem juntos uma nova sociedade" (ONU, 2018).

Além das campanhas e ampliação das discussões de forma globalizada, os movimentos identitários são responsáveis pelo aumento das discussões de desigualdade de gênero em âmbito acadêmico, e pela maior participação ativa na política brasileira. Visto que, atualmente, no Congresso Nacional brasileiro existem bancadas que se denominam defensores da causa LGBT, assim como, defensores da questão agrária e do desarmamento.

A representatividade na política atual melhorou com a presença desses grupos na política brasileira. Quebrando com a hegemonia tradicional, esses grupos buscam 
melhorias em suas condições de vida, defendem os direitos de adoção e de casamento civil por casais homoafetivos; como já é possível a configuração da união estável por casais do mesmo sexo. Essa última atua como uma das conquistas dessa nova atuação política diversificada.

A manutenção da atuação por partes desses grupos ainda persiste, devido ao fato de que nem todas as reivindicações foram de fato atendidas, e nem todas as agendas superadas. Ainda se verifica questões como: o crescente número de violência contra mulheres e homossexuais, o casamento civil e a adoção por casais do mesmo sexo. O que sugere que ainda faz-se necessário e bastante válido a existência da atuação feminista e dos movimentos identitários por um longo período para que todos os seus direitos sejam efetivados.

\section{REFERÊNCIAS}

BANDINTER, E. XY: sobre a identidade masculina. Rio de Janeiro: Nova Fronteira, 1993.

BEAUVOIR, Simone de. O segundo sexo [tradução Sérgio Miller]. Rio de janeiro: Nova Fronteira, 1949.

BEAUVOIR, Simone de. Le deuxième sexe, I. Paris: Gallimard, 1986.

BOURDIEU, Pierre. A Dominação Masculina. Rio de Janeiro: Bertrand Brasil, 1999.

BRYM, Robert; LIE, John; HAMLI, Cynthia Lins (et al). Sociologia: Uma bússola para o novo mundo. São Paulo: Thomson, 2006.

COLLINS, Patricia Hill. O que é um nome? Mulherismo, Feminismo Negro e além disso. Pagu, Campina, n. 51, 2017. Disponível em:< http://www.scielo.br/pdf/cpa/n51/1809-4449-cpa18094449201700510018.pdf>. Acesso em: 24 fev. 2020.

ENGELS, Friedrich. A origem da família, da propriedade privada e do Estado. São Paulo: Centauro Editora, 2006.

FACCHINI, Regina. Sopa de letrinhas? Movimento homossexual e produção de identidades coletivas nos anos 90. Rio de Janeiro: Garamond, 2005.

FIGES, Eva. Patriarcal Attitudes. Nova lorque: Stein and Day, 1970.

FRIEDAN, Betty. Mística feminina-Tradução de Áurea B. Weissemberg. Rio de Janeiro: Vozes, 1971.

GREER, Germaine. A mulher inteira. Rio de Janeiro/São Paulo: Record, 2001. 
GHANEM, Elie. Alain Touraine e a produção da sociedade. São Paulo: Cedi, 1989.

GIDDENS, Anthony. Sociologia. Trad. Alexandra Figueiredo. Ana Patrícia Duarte Baltazar. Catarina Lorga da Silva. Patrícia Matos. Vasco Gil. 6 ed. Porto Alegre: Penso, 2011.

HEYWOOD, Andrew. Ideologias Políticas: do feminismo ao multiculturalismo. v. 2. São Paulo: Ática, 2010.

HOOKS, bell. Erguer a voz: pensar como feminista, pensar como negra. Trad. Cátia Bocaiuva Maringolo. São Paulo: Elefante, 2019.

FACCHINI, Regina. Movimento Homossexual e produção de identidades coletivas nos anos 90. Rio de Janeiro: Garamond, 2005.

MILLETT, Kate. Política Sexual. México, 1975.

MITCHELL, Juliet. Woman's estate. Maryland: Penguin Books, 1971.

OLIVEIRA, Glaucia da Silva Destro. Construção, negociação e desconstrução de identidades: do movimento homossexual ao LGBT. Pagu, Campinas, n. 34, 2010. Disponível em: <http://www.scielo.br/scielo.php?script=sci_arttext\&pid=S010483332010000100015>. Acesso em: 28 jan. 2020.

OLIVEIRA, Antonio Martins. Não se nasce homem, nem necessariamente se torna. In: SILVA, Antonio de Pádua Dias. RIBEIRO, Maria Goretti. (Orgs.). Rumos dos estudos de gênero e de sexualidades da agenda contemporânea. Campina Grande: Eduepb, 2013, p. 25-41.

ONU. Eles por Elas. In: ONU Mulheres. Disponível em: <http://www.onumulheres.org.br/elesporelas/>. Acesso em: 29 abr. 2020.

SILVA, Carmem; CAMURÇA, Silvia. Feminismo e movimento de mulheres. Recife: Edições SOS Corpo, 2010. 


\title{
CAPÍTULO XV
}

\section{GARANTIA DA DIGNIDADE HUMANA PARA A POPULAÇÃO LGBTQIA+ EM PRIVAÇÃO DE LIBERDADE NO SISTEMA CARCERÁRIO BRASILEIRO}

\author{
Jefferson Matheus Medeiros de Araújo ${ }^{1}$ \\ Olívia Maria Cardoso Gomes ${ }^{2}$
}

\footnotetext{
${ }^{1}$ Graduando do curso de Direito no Centro de Educação Superior Reinaldo Ramos/CESREI.

2 Doutoranda em Ciências Jurídicas Públicas pela Universidade do Minho. Advogada, professora universitária. Professora orientadora do presente artigo.
}

\section{RESUMO}

O presente artigo objetiva discorrer sobre a Garantia dos Direitos Humanos para a População LGBTQIA+ em Privação de Liberdade no Sistema Carcerário Brasileiro. A discussão mostra-se pertinente em virtude da ausência de um tratamento digno para aqueles que são vulneráveis ainda enquanto cidadãos, e que ao terem a sua liberdade cerceada acabam sofrendo demasiadamente nas penitenciárias. Partindo de um método dedutivo, com pesquisa descritiva e explicativa, baseada em análise bibliográfica. A princípio, a pesquisa abordará a construção histórica dos Direitos Humanos, mostrando o quanto o seu conceito se modificou durante os séculos, saindo de uma perspectiva de privilégio para uma de inerente a todos enquanto seres humanos. Por conseguinte, o estudo será direcionado a questão da sexualidade, conceituando-a e destacando as suas principais características, analisando as questões de gênero e aspectos importantes que definem a maneira de ser dos indivíduos. Por fim, considerando tratados internacionais e artigos de leis, assim como expondo relatórios penitenciários e um relatório publicado pelo ministério dos Direitos Humanos, a pesquisa visa expor a real situação em que se encontra os encarcerados LGBTQIA+, consequentemente, apresentará sugestões para um tratamento penal adequado, que possibilite a preservação e garanta direitos básicos para estas pessoas sob a luz de resoluções já existentes relacionando-as com a legislação pátria.

Palavras-chave: LGBTQIA+; Dignidade Humana; Sistema carcerário brasileiro.

\section{INTRODUÇÃO}

É inegável que o sistema prisional brasileiro está um tanto quanto distante do que seria tido como o ideal para restringir as pessoas de sua liberdade e retribuir proporcionalmente o mal que eles cometeram a sociedade. 
No julgamento da Medida Cautelar na Arguição de Descumprimento de Preceito Fundamental (ADPF) № $347^{1}$, o Supremo Tribunal Federal declarou o Estado de coisa inconstitucional dentro dos cárceres de todo o território brasileiro, aduzindo sobre o sofrimento que as penitenciarias acarretam aos apenados, que contraria preceitos constitucionais e a uma das principais finalidades da privação de liberdade, quais seja, a ressocialização.

O sistema penitenciário brasileiro tornou-se uma escola para o tráfico, segundo o Ministro Marco Aurélio em seu voto na ADPF № 347 (2015, p. 26), ao qual foi relator, “Os cárceres brasileiros não servem à ressocialização dos presos. É incontestável que implicam o aumento da criminalidade, transformando pequenos delinquentes em 'monstros do crime' ".

Evidentemente, a prisão deixou de ser um local que serviria como um preparo para que os indivíduos voltassem a conviver em sociedade "curados" da vida delituosa, tornando-se de maneira inegável um local que se pune demasiadamente com o cerceamento da liberdade e a supressão de direitos fundamentais.

Ao que tange a situação de um LGBTQIA+, esta consegue ser pior do que a de qualquer outro detento, uma vez que, ainda livres estes indivíduos são marginalizados, discriminados e tratados como uma escoria social, e na condição de encarcerado, eles sofrem de forma potencializada por todos os estigmas sociais que são ampliados nas penitenciárias.

A discriminação inicia-se dentro do lar dos LGBTQIA+, e acaba se estendendo por toda a sociedade, dificultando demasiadamente a vida destes indivíduos, pois, sem amparo familiar, sem condições de conseguir um emprego formal, resta a estes a vida delituosa e a prostituição como uma única alternativa para sobreviverem.

De acordo com BENEVIDES (2017), cerca de 90\% da população de Travestis e Transexuais utilizam a prostituição como fonte de renda (ANTRA, 2017, pág. 18) ${ }^{2}$. Tratase de um efeito dominó, em primazia são rejeitados pela família, pelo mercado de trabalho e concomitantemente pelo próprio Estado, visto que a sua morosidade em criar

${ }^{1}$ ADPF 347 MC, Relator(a): Min. MARCO AURÉLIO, Tribunal Pleno, julgado em 09/09/2015, PROCESSO ELETRÔNICO DJe-031 DIVULG 18-02-2016 PUBLIC 19-02-2016.

2 BENEVIDES, Bruna. Mapa dos Assassinatos de Travestis e Transexuais no Brasil em 2017, pág. 18. Disponível em: https://antrabrasil.files.wordpress.com/2018/02/relatc3b3rio-mapa-dosassassinatos-2017-antra.pdf 
mecanismos de proteção a minorias acaba impondo como única alternativa de vida a essas pessoas o mundo da prostituição e a prática de delitos.

De forma incontestável, toda a política nacional voltada as penitenciarias precisa de uma reforma, tendo como finalidade rever os critérios e formas que tratam os indivíduos privados de liberdade, e além disto, precisa dispor de um olhar governamental sobre aqueles que possuem vulnerabilidade adicional dentro dos cárceres.

As penitenciárias brasileiras, conforme aduz ZAMBONI (2017, p.103) ${ }^{1}$, é uma "bomba de testosterona", uma bomba relógio prestes a explodir, isto em detrimento de que, segundo o autor "a substância que constitui a masculinidade orgulhosamente ostentada pelos presos aparece também como responsável por uma agressividade imprevisível e explosiva", logo tem-se a compreensão de uma relação entre masculinidade e violência.

Essa relação será discorrida neste trabalho, levando em consideração a compreensão da vida delituosa como uma coisa de "macho", que não aceita os indivíduos desviantes do padrão binário, sobretudo, e de forma acentuada os LGBTQIA+ no mundo da criminalidade, de tal modo, este fato corrobora com a violência enfrentada por eles dentro das penitenciarias.

Neste trabalho foi utilizado um método dedutivo, com pesquisa descritiva e explicativa, baseada em análise bibliográficas, bem como far-se-á observações deste tema levando em consideração tratados internacionais, artigos de leis, assim como expondo relatórios penitenciários e um relatório publicado pelo ministério dos Direitos Humanos intitulado de "LGBTQIA+ nas prisões do Brasil: Diagnóstico dos procedimentos institucionais e experiências de encarceramento".

\section{EVOLUÇÃO HISTORICA DA DIGNIDADE DA PESSOA HUMANA}

O conceito da dignidade humana já passou por grandes transformações ao longo dos séculos, e mesmo versando sobre um tema tão antigo e importante, atualmente ainda não existe uma definição que possa representa-la com clareza, uma

${ }^{1}$ ZAMBONI, Márcio. O barraco das monas na cadeia dos coisas: notas etnográficas sobre a diversidade sexual e de gênero no sistema penitenciário, 2017, P. 103. Disponível em: https://arace.emnuvens.com.br/arace/article/viewFile/135/71. 
vez que, a sua complexidade envolvida com sua particularidade varia entre cada indivíduo, momento histórico e as diferentes ideologias políticas.

A princípio em reflexões filosóficas clássicas, apenas possuía dignidade aquele que fosse reconhecido e tivesse importância social, ou seja, a dignidade não era algo pertencente todos, pois existia apenas um pequeno grupo merecedor dela, propiciando assim a existência de pessoas mais ou menos dignas, como afirma Martínez (2003, p.21), "desde la antigüedad aparece la idea da dignidad, como honor, causa o título, la imagen que da uno representa o se la reconoce en la vida social"

Com o advento do cristianismo na antiguidade, a noção de dignidade passa a ser usada pela igreja como uma forma de sustentar a sua ideologia, pregando que o homem é a imagem e semelhança de Deus, e que, se por ventura alguém vier a negar a dignidade do homem, logo estaria negando a cristo.

A compreensão da dignidade passou a ter um valor de ordem moral religiosa pertencente a todos os homens, contudo tal pensamento era vago e impreciso, possibilitando que essa dignidade não ultrapassasse o plano filosófico. Conforme expõe Fabio Konder (2003, p. 13), a igualdade universal dos filhos de Deus só valia, efetivamente, no plano sobrenatural.

Na Idade Média, São Tomás de Aquino utilizou a expressão "Dignitas humana" pela primeira vez, afirmando que "a dignidade é inerente ao homem, como espécie; e ela existe in actu só no homem". FACHIN (2009, p. 34). Observa-se então a dignidade do homem por outra perspectiva, ao qual a priori versava sobre algo que dependia da sua posição social, e apresenta-se agora a ideia de sua atribuição a todos os seres humanos, de forma inerente, de valor inato.

Com o advento da modernidade renascentista entre os séculos XV e XVI, houve o rompimento de pensamentos teocêntricos, dando espaço para os pensadores egocêntricos que afastavam a ideia de Deus como o centro de tudo, e de toda explicação lógica para a vida, trazendo assim, o homem para o papel principal e como fonte da explicação de tudo, tornando-se um ser cultural e protagonista de sua história.

Explica Pedro Dalle (1990, p.62) que: "Os homens da renascença, mais que os de qualquer outra época passada, tomaram consciência de que o homem não é um simples espectador do universo, mas que o pode modificar, melhorar, recriar". 
Com fulcro nessa nova perspectiva de se observar o papel do homem no mundo, atribui-se a Giovani Pico della Mirandola do século XV a ser um dos primeiros filósofos a fundamentar a dignidade humana fora dos limites religiosos, colocando o homem como artífice do seu destino, através do próprio conhecimento de perfectibilidade e autodeterminação.

Contudo, foi Immanuel Kant que fortaleceu a compreensão moderna acerca da dignidade da pessoa humana, entre os séculos XVII e XVIII. Para Kant, a concepção de dignidade humana advém da racionalidade e autonomia do ser humano, onde de acordo com Ingo Wolfgang $(2012$, p.42) a autonomia da vontade, entendida como a faculdade de determinar a si mesmo e agir em conformidade com a representação de certas leis, é um atributo apenas encontrado nos seres racionais, constituindo-se no fundamento da dignidade da natureza humana.

Kant afirmava que o homem por sua racionalidade existia como um fim em si mesmo, e não como um meio para outras ações. Sendo assim, não podendo este ser tratado como um meio, pois aquilo que vier a ser um meio possuiria valor, equivalente, e facilmente seria substituível, já ao observamos o homem enquanto um fim em si mesmo, pode-se afirmar que este não poderá ser substituído ou ter equivalente, e só assim tornar-se-á um ser possuidor de dignidade, onde as coisas possuem um preço, já os indivíduos possuem dignidade.

Conforme ensina Barroso (2010, p. 15), "a filosofia kantiana foi integralmente construída sobre as noções de razão e de dever, e sobre a capacidade do indivíduo de dominar suas paixões e identificar, dentro de si, a conduta correta a ser seguida", de modo que, o indivíduo possua autonomia e capacidade de se expressar em conformidade com a representação de certas leis.

Na pós-modernidade o respectivo tema ganhou espaço no cenário jurídico mundial, tendo em vista que, durante o período de guerra o mundo observou a "coisificação" do ser humano, momento este em que o Estado fez a utilização dos indivíduos como meros objetos de guerra, isto em apego ao puro direito, sem se valer de outras fontes complementares como a moral e a ética, fato este que preconizou o rompimento da sociedade com o positivismo exacerbado.

Com o advento do pós-positivismo e consequentemente com a reaproximação do Direito e a ética, a dignidade humana adquiriu status constitucional na maior parte 
das nações, sendo ela a justificação moral dos direitos humanos e direitos fundamentais, tornou-se um dos principais fundamentos dos Estados Democráticos.

Após a segunda guerra mundial, a dignidade humana começou a integrar-se em documentos jurídicos internacionais, a exemplo da Carta da ONU de 1945, a Declaração Universal dos Direitos do homem em 1948 e inúmeros outros documentos e tratados de cunho internacional que visam a promoção dos direitos humanos e universalização da dignidade humana.

Barroso (2010, p. 21) apresenta três conteúdos essenciais da dignidade, sendo eles o valor intrínseco, a autonomia de vontade e o valor social da pessoa humana, de modo que, em se tratando do valor intrínseco, "trata-se da afirmação de sua posição especial no mundo, que a distingue dos outros seres vivos e das coisas. Um valor que não tem preço". Enquanto que, a autonomia de vontade é "a capacidade de autodeterminação, o direito do indivíduo de decidir os rumos da própria vida e de desenvolver livremente sua personalidade" e por fim, o valor social da pessoa humana consiste nos "valores compartilhados pela comunidade, segundo seus padrões civilizatórios ou seus ideias de vida boa".

A dignidade humana teve seu conceito amadurecido ao longo dos séculos, e em uma reflexão historicista do homem até chegar a compreensão atual, que também não é algo que a define por completo, fato este que os autores e estudioso da área buscam delimita-la para que possa se estender na sua melhor compreensão de forma universal entre os povos, apesar de que, a sua definição está condicionada aos valores sociais, ideológicos, políticos e a realidade de cada época.

\section{SEXUALIDADE E GÊNERO}

A sexualidade humana é um tanto quanto complexa, pois, conforme ensina Lima Junior (2012, p. 198), ela atrela-se aos discursos das ciências da vida e da sociedade, servindo de referencial para legitimá-la. Perpassa as práticas embora não consiga detêlas, pois o sexo é fluxo instintivo.

Ao observamos a sexualidade perante os discursos sociais, torna-se evidente a influência que o Estado tem sobre a vida das pessoas, na forma com que devam se autodeterminar, no entanto, por ser defeso um controle através das leis, criam-se mecanismos que segundo Foucault (1988, p. 295) seria uma espécie de "Polícia do sexo: 
isto é, necessidade de regular o sexo por meio de discursos úteis e públicos e não pelo rigor de uma proibição".

É inegável que a sexualidade humana possua diversas formas de se expressar, no entanto, dentre os séculos foi corroborado uma ideia, sobretudo por parte das religiões, de que a sexualidade possuía como objetivo central a reprodução da espécie humana, sendo então rotulado como "normal" apenas os que fazem parte do duplo binário, ou seja, o homem e a mulher que se sentem atraídos afetiva e sexualmente por alguém do sexo oposto ao seu.

De tal modo, ensina LIMA JÚNIOR (2012, p. 32) que a sexualidade é posta em funcionamento atrelando-se a fatos específicos, como aqueles referentes ao lema da reprodução da espécie, logo qualquer que fosse a relação de prazer sem essa finalidade seria nitidamente considerada amoral e pecaminosa. Observa-se que os meios utilizados para o controle sobre a sexualidade das pessoas têm um apego moral, religioso e finalístico.

Levando em consideração que a sexualidade era vista sob a ótica da reprodução humana, bem como extremamente necessária para um fundamentalismo do binarismo sexual, as pessoas desviantes desse "normal" foram rotuladas como doentes, afinal, no ano de 1977 a Organização Mundial de Saúde (OMS) incluiu em sua classificação internacional de doenças (CID) o "homossexualismo" como um transtorno mental, sendo este retificado da lista apenas em 17 de maio 1990, onde o sufixo "ismo" da palavra que dava a ideia de doença foi substituída "idade", tornando-se homossexualidade, trazendo uma perspectiva de um modo de ser do indivíduo.

A sexualidade humana é bem mais expressiva do que tais pensamentos iniciais, visto que, ela não se prende a questões fisiológicas, órgãos genitais, informações cromossômicas, ou a capacidade reprodutiva dos indivíduos, pois ela se forma através de uma combinação de fatores biológicos, sociais e psicológicos.

A Organização Mundial de Saúde (OMS), define a sexualidade como:

Uma energia que nos motiva a procurar Amor, contato, ternura, intimidade, que se integra no modo como nos sentimos, movemos tocamos e somos tocados; É ser-se sensual e ao mesmo tempo sexual; ela influencia pensamentos, sentimentos, ações e interações, e por isso influência também a nossa Saúde física e mental. 
A sexualidade através da conceituação dada pela OMS abre a possibilidade de se visualizar diversas formas de sua expressão e ramificação, pois, entendendo se tratar de uma combinação de fatores sociais, psicológicos e biológicos, tem-se então os elementos que a compõe, tais como: o sexo biológico, a orientação sexual e a identidade de gênero.

O sexo biológico versa sobre as questões fisiológicas do ser humano, ligado diretamente ao nosso órgão genital, em uma visão simplicista trata-se da capacidade reprodutiva, ou seja, uma característica meramente fisiológica. A orientação sexual, por sua vez, se refere a uma característica íntima do indivíduo, sendo a atração afetiva e/ou sexual deste em relação à outra pessoa.

De acordo com os Princípios de Yogyakarta $(2006)^{1}$ a orientação sexual é uma referência à capacidade de cada pessoa de ter uma profunda atração emocional, afetiva ou sexual por indivíduos de gênero diferente, do mesmo gênero ou de mais de um gênero, assim como, ter relações íntimas e sexuais com essas pessoas.

As formas mais expressivas da orientação sexual são: O Heterossexual, onde o indivíduo se sente atraído afetiva e/ou sexualmente por alguém do sexo oposto; 0 Homossexual, sendo indivíduos que se sentem atraídos afetiva e/ou sexualmente por alguém do mesmo sexo (Gays e Lésbicas); E os Bissexuais, onde estes por sua vez se sentem atraídos afetiva e/ou sexualmente por pessoas de ambos os sexos/ou gênero.

Em relação ao gênero, o psiquiatra norte-americano Robert Stoller vem desenvolvendo estudos contínuos sobre a questão da masculinidade, feminilidade e da identidade de gênero, e foi através do livro "Sex and Gender" que Stoller introduziu a palavra gênero para criar um critério diferente do termo sexo, que estava tão somente ligado às condições biológicas.

Com fulcro nessa ideia do gênero ligada a questões biológicas e a construção social, Judith Butler em sua obra "Problemas de Gênero", faz uma distinção entre sexo e gênero, ao qual expõe ser o sexo algo natural, enquanto o gênero é construído, e essa construção é imposta aos indivíduos de forma determinista. Aduz Butler (2003, p, 26.):

${ }^{1}$ Os Princípios de Yogyakarta é um documento internacional que versa sobre a legislação internacional de direitos humanos em relação à orientação sexual e identidade de gênero. Firmados no ano de 2006, em Yogyakarta, Indonésia, pela Comissão Internacional de Juristas e o Serviço Internacional de Direitos Humanos. 
“(...) a ideia de que o gênero é construído sugere um certo determinismo de significados do gênero, inscritos em corpos anatomicamente diferenciados, sendo esses corpos compreendidos como recipientes passivos de uma lei cultural inexorável (...) Quando a 'cultura' relevante que 'constrói' o gênero é compreendida nos termos dessa lei ou conjunto de leis, tem-se a impressão de que o gênero é tão determinado e tão fixo quanto na formulação de que a biologia é o destino. Nesse caso, não a biologia, mas a cultura se torna o destino".

Butler aduz sobre os problemas ocasionados por esta ligação cultural sobre sexo e gênero onde as pessoas são condicionadas ao sistema duplo binário, que unemse as questões biológicas de modo que, um indivíduo ao nascer com um pênis, será menino, e via de regra deve ser atraído afetivo e sexualmente por uma mulher, e de mesmo modo ocorre com elas, ao nascer com uma vagina, considerar-se-á uma mulher, e por conseguinte deve relacionar-se com homens.

Acontece que, conforme ensina Butler (2003. p, 25.), "O gênero não deve ser meramente concebido como a inscrição cultural de significado num sexo previamente dado". É em virtude destas imposições culturais que antecedem inclusive a formação de consciência do indivíduos - rotulados desde a concepção - que Butler afirma que não a biologia, mas a cultura se torna o destino do indivíduo.

De tal modo, entende-se que, essa questão de gênero é um cumulativo de fatores, apoiado em ideias e valores culturais, que se expressam de forma impositiva por meio do binarismo sexual que consiste na naturalização de uma relação entre 'sexogênero-sexualidade', ao qual desconsidera todos aqueles que possuem desvios da dita "normalidade", apresentando como consequência uma severa repressão, sobretudo, social.

A identidade de gênero, segundo os Princípios de Yogyakarta (2006) é a profundamente sentida experiência interna e individual do gênero de cada pessoa, que pode ou não corresponder ao sexo atribuído no nascimento, incluindo o senso pessoal do corpo (que pode envolver, por livre escolha, modificação da aparência ou função corporal por meios médicos, cirúrgicos ou outros) e outras expressões de gênero, inclusive vestimenta, modo de falar e maneirismos. 
As diversas identidades de gênero vão além do já estabelecido padrão binário e rompe inevitavelmente a relação naturalizada entre o sexo, gênero e sexualidade, pois consiste em fatores pessoais de como o indivíduo se identifica sexualmente e socialmente. Dentre as diversas identidades de gênero, existe os transgêneros que se expressam como o sexo oposto, caso este das travestis, e os transexuais.

Os transexuais sentem que a sua anatomia não corresponde à identidade de gênero, fato este que desencadeia a realização de cirurgias e tratamentos hormonais para que o seu corpo se adeque a forma como ele(a) se identifica, ressalvando que, apesar dos procedimentos serem recorrentes, nem sempre as pessoas transexuais manifestam esse desejo de modificar-se fisiologicamente, e dentre eles, encontram-se a transmulher e transhomem.

Cabe destacar que, independentemente da expressão ou orientação sexual do indivíduo, todos possuem a capacidade de se autodeterminar e a eles lhes são garantido a autonomia de vontade, e caso o Estado não respeite isto, estará violando diretamente a dignidade humana, pois conforme já destacado, um dos elementos essências da dignidade é a autonomia de vontade do indivíduo.

\section{O ENCARCERAMENTO DOS LGBTQIA+}

Com o olhar transcrito sobre a dignidade humana e o que ela representa para a sociedade, bem como, com os esclarecimentos necessários acerca da sexualidade e as suas formas de expressão, podemos assim discorrer sobre a situação de um apenado LGBTQIA+.

Diante da marginalização que se dá às pessoas que fogem da heteronormatividade, temos ciência de que, como afirma SESTOKAS (2015) Lésbicas, gays, travestis e transsexuais apresentam vulnerabilidades adicionais pelo seu modo de ser, e dentro de uma penitenciária preconceitos e estigmas voltados à população LGBTQIA+ se intensificam demasiadamente, algo que viabiliza uma dupla punição, visto que, estão presos em liberdade e desumanizados na ausência dela.

Ao afirmar que estão presos em liberdade, significa dizer que essa população é vítima de constante homofobia e transfobia dentro do meio social que se mostra incompreensível e insciente ao que tange a diversidade sexual e de gênero, propiciando 
então, um medo constante por parte daqueles que apresentam-se de forma diversa a estabelecida como normal.

Em se tratando da desumanização na ausência de liberdade, diz respeito a todo o sofrimento enfrentado pela população LGBTQIA+ encarcerada, como afirma CAPPELLARI (2018, p. 99) à violência enfrentada por essa população no interior do sistema penitenciário, ocorre tanto institucionalmente quanto pelo chamado código moral compartilhado entre os detentos, onde segundo GUERSON (2018, p. 14) o reflexo das relações socias baseadas no preconceito reflete no interior das prisões de forma mais bruta, potencializando onde há homens agressivos que querem ser temidos pelos outros em busca de um status.

O status supracitado é uma hierarquização de poder existente dentro da própria unidade prisional, conforme aduz GUERSON (2018) existem divisões no sentindo em que os presos mais perigosos se impõem para que não sejam abusados ou explorados, com isso eles acabam oprimindo, explorando e abusando os indivíduos mais fracos da unidade, os apenados considerados mais fortes estão no topo da relação de poder que comandam alas e celas no interior das prisões.

A parte mais fraca fica encarregada de suportar os diversos abusos e consequentemente são submetidos a situações degradantes a fim de continuarem vivos dentro do cárcere, que segundo ZAMBONI (2017), as cadeias são definidas como uma "bomba de testosterona", tendo em vista que a ideologia que predomina é masculina, com a ideia de que como afirma CAPPELLARI (2018) o homem tem que ser "macho" para se posicionar no meio criminoso e este ambiente não aceita o estereótipo feminino, apoiando assim o sentimento de poder vindo daqueles que se enquadram na heteronormatividade, bem como, reproduz a ideia social da superioridade masculina.

As pessoas com a identidade de gênero que transgridam o binarismo sexual, a exemplo dos homossexuais, travestis e transgêneros, são imediatamente postas para o status mais vulnerável do cárcere e consequentemente, por possuírem características mais afeminadas, logo são suscetíveis a abusos sexuais e obrigados a desenvolvimento de atividades domésticas.

É inegável que existe enraizada em nossa cultura a ideia de que atividades domésticas seja uma função "típica da mulher", um pensamento sexista que consegue adentrar os muros das penitenciárias, e como pontua GUERSON (2018), os LGBTQIA+ 
são obrigados a realizar atividades domésticas, como cuidar das roupas dos demais detentos, cozinhar e fazer a limpeza em banheiros e interior das celas.

Ademais, é possível constatar dentro dos cárceres a utilização dos LGBTQIA+ como moeda de troca, ao qual os detentos hierarquicamente superiores utilizam-se destes classificados como inferiores para dispor dos mais diversos itens, em suma, são postos como um simples pagamento nas relações de poder informal existente entre os reclusos.

É evidente que a população LGBTQIA+ em privação de liberdade não possui sequer o mínimo possível para que cumpra sua pena com condições dignas, sendo expostos a um demasiado sofrimento e situações que podem colocar em risco a sua saúde, uma vez que, as trocas supracitadas possuem como finalidade a satisfação sexual de outros apenados.

Essas conduta os torna mais vulneráveis a contrair doenças sexualmente transmissíveis, conforme aduz GUERSON (2018), por serem mais expostos a práticas sexuais muitas vezes abusivas e sem proteção, estão mais dispostos a contrair doenças sexualmente transmissíveis, como hepatite, sífilis, HIV, entre outras.

Com base em toda a vulnerabilidade apresentada pelos detentos pertencentes ao grupo LGBTQIA+, criou-se uma resolução com a finalidade de reduzir os impactos e garantir as devidas condições humanas para o encarceramento destes indivíduos. A Resolução Conjunta $\mathrm{N}^{\circ} 1$, de 15 de abril de 2014, assinada pelo Conselho Nacional de Política Criminal e Penitenciária (CNPCP) e pelo Conselho Nacional de Combate à Discriminação (CNCD/LGBTQIA+), onde delineou-se parâmetros de acolhimento da população LGBTQIA+ no sistema prisional.

\subsection{Resolução Conjunta de $N^{\circ} 1$}

A resolução conjunta de $\mathrm{N}^{\circ} 1$ foi publicada no diário oficial da união em 15 de abril de 2014 pelo Conselho Nacional de Combate à Discriminação corroborada pelo Conselho Nacional de Política Criminal e Penitenciário, estabelece parâmetros para o acolhimento dos LGBTQIA+ em privação de liberdade.

Composta por 12 artigos, a resolução versa sobre o que se entende por LGBTQIA+, logo em seu Art.1², Parágrafo único, dispondo sobre Lésbicas, Gays, Bissexuais, Travestis e Transsexuais. Apesar de ser aparentemente uma conquista ao 
que se refere o acolhimento LGBTQIA+ no sistema prisional, a resolução mostra-se um pouco incompreensível na conceituação das diferentes formas de gênero e sexualidade.

No inciso $\mathrm{V}$ do art. $1^{\circ}$, parágrafo único a resolução aduz sobre os Transexuais onde o texto expõe que são pessoas psicologicamente de um sexo e anatomicamente de outro, rejeitando o próprio órgão sexual biológico.

Conforme já transcrito no tópico que versa sobre a sexualidade, errônea é esta perspectiva introduzida pela Resolução, uma vez que ao que tange os transexuais, estes nem sempre rejeitam o seu órgão sexual biológico.

Percebe-se que, até tentando ajudar o Estado acaba criando mecanismos falhos para o acolhimento destas pessoas nos cárceres, e concomitantemente aderem a ideia de que Gênero, sexo e sexualidade compõe um todo sem que possam existir de formas distintas.

Ademais, de acordo com o que se estabelece dentre os parâmetros, encontram-se direitos relativos à identificação de acordo com o seu nome social, que deverá ser disposto no registro de admissão no estabelecimento prisional (Art. $2^{\circ}$ ), bem como, considerando a vulnerabilidade apresentada pelos LGBTQIA+, dispõe que as unidades prisionais destinem um espaço de vivencia especifico, ao qual a transferência da pessoa presa que se enquadre na classificação transcrita do art. $1^{\circ}$, ocorra mediante sua solicitação $\left(\operatorname{Art} .3^{\circ}\right)$.

Ao que tange os transexuais, o art. $4^{\circ}$ dispõe o seguinte: "As pessoas transexuais masculinas e femininas devem ser encaminhadas para as unidades prisionais femininas". Destacando que, este dispositivo serviu como fundamento para uma decisão do Supremo Tribunal Federal no ano de 2018, ao qual o Ministro Luís Roberto Barroso concedeu um Habeas Corpus $^{1}$ a duas transexuais, para que fossem conduzidas a um estabelecimento prisional compatível com a sua orientação sexual.

Observa-se que, mesmo existindo uma resolução com parâmetros pertinentes ao acolhimento dos LGBTQIA+ nos estabelecimentos prisionais, ainda existe resistência para efetiva-los, grande exemplo disto é o caso citado anteriormente, ao qual foi necessário chegar ao conhecimento da suprema corte para que determina-se o cumprimento do que se expõe claramente o Art. $4^{\circ}$ da resolução aqui analisada.

\footnotetext{
${ }^{1}$ Habeas Corpus 152.491, São Paulo, Relator Min. Roberto Barroso, 2018.
} 
Dentre os avanços e direitos garantidos, também aduz a resolução sobre questões pertinentes a vestimenta, onde fica facultado as travestis e transexuais o uso de roupas características, do tipo masculina ou feminina, possibilitando também a manutenção de cabelos compridos (Art. $5^{\circ}$ ), sendo garantido o direito a visita intima (Art. $6^{\circ}$ ), bem como uma atenção integral à saúde, destacando o caráter especial proposto para as Travestis, o Transhomem ou a Transmulher, que possuem o direito manter 0 tratamento hormonal e um acompanhamento de saúde especifico.

Conforme se observa, apesar de algumas especificidades, a resolução é benéfica ao que tange a garantia da dignidade humana dos LGBTQIA+ em privação de liberdade, visto que, acaba rompendo perspectivas deterministas e adota meios que preservem a identidade de gênero de cada qual, da forma como ele(a) se visualiza e se expressa.

Ademais, versa a resolução sobre a questão educacional dos apenados LGBTQIA+, garantindo-lhes o acesso ou continuação de sua formação educacional e profissional $\left(\right.$ art. $9^{\circ}$ ), versando também sobre a capacitação dos profissionais dos estabelecimentos prisionais com fulcro nos direitos humanos e princípios da não discriminação e igualdade (art. 10).

Essa questão educacional é de suma importância em ambos os lados, pois em se tratando do apenado LGBTQIA+, esta será uma oportunidade real de estudar sem ser discriminado pelo seu modo de ser, enquanto que, a educação voltada aos agente prisionais propicia que estes não venham a cometer discriminação com os encarcerados LGBTQIAt, viabilizando um respeito institucional por eles.

Por fim, os artigos que finalizam a resolução reafirmam direitos relativos ao auxílio-reclusão aos dependentes do segurado recluso, incluindo o cônjuge ou companheiro (Art. 11).

Diversos são os problemas do apenado LGBTQIA+ em privação de liberdade, e tamanha é a problemática encontrada no sistema prisional brasileiro, declarado como "estado de coisa inconstitucional" pelo Supremo Tribunal Federal através da ADPF № 347, julgado em 09 de setembro de 2015.

Ao tocante dos grupos vulneráveis, encontra-se na ADPF № 347, que "há relatos de travestis sendo forçados à prostituição. Esses casos revelam a ausência de 
critério de divisão de presos por celas", os ministros reconhecem a necessidade de uma divisão carcerária de modo a atender as particularidades de cada grupo.

É importante ressalvar que maior parte destas pessoas sobrevivam da prostituição em períodos que antecedem o encarceramento, e que dentro das penitenciarias acabam seguindo os mesmos passos para que possam sobreviver ou "garantir" determinadas prerrogativas. Encontram na prostituição uma forma de conseguir cigarros, privilégios e produtos de higiene pessoal.

Não se pode afastar a evidente exploração sexual existente nas penitenciarias preconizada aos LGBTQIA+, ainda no tocante da ADPF № 347, afirma-se que, os detentos estão sujeitos a condições de discriminação social, racial, de gênero e de orientação sexual. Isso aborda a latente preocupação que se tem em deixar determinadas pessoas simplesmente jogadas na "bomba de testosterona" que é o cárcere brasileiro.

É importante frisar que, o preconceito e a discriminação que a população LGBTQIA+ enfrenta não parte apenas dos outros apenados com quem dividem o cárcere, pois os próprios funcionários da penitenciaria reproduzem preconceitos e estigmas, marginalizando e suprimindo ainda mais a dignidade destes.

Tudo corrobora para a ideia de que, o sistema prisional brasileiro está cada vez mais insustentável e um tanto quanto desumano, com falhas que vão do seu corpo institucional e parte para as condições físicas de se deter alguém com a finalidade de permanecer privado de liberdade por muitos anos.

Como bem destacado na ADPF, afirma-se que: "O quadro não é exclusivo desse ou daquele presídio. A situação mostra-se similar em todas as unidades da Federação, devendo ser reconhecida a inequívoca falência do sistema prisional brasileiro".

Valendo-se disto, é evidente que a dignidade humana é suprimida junto a liberdade dos apenados LGBTQIA+, que graças a omissão demasiada do Estado, sofrem durante toda a sua vida. A priori são excluídos da sociedade, fazendo com que não possam ter uma educação digna, coisa que consequentemente os levam para a marginalização, que concomitantemente os fazem virar delituosos, e ao entrarem nos cárceres são humilhados, excluídos, discriminados e marginalizados pelo Estado.

Uma alternativa viável para amenizar os impactos sofridos pela população LGBTQIA+ privados de liberdade, seria a adoção de um critério de divisão de presos por 
cela, que inclusive está previsto na Resolução Conjunta de $n^{\circ} 1$, de 15 de abril de 2014, em seu Art. 3o , onde aduz que: "Às travestis e aos gays privados de liberdade em unidades prisionais masculinas, considerando a sua segurança e especial vulnerabilidade, deverão ser oferecidos espaços de vivência específicos", seguido pelo seu $\S 2$ ?: "A transferência da pessoa presa para o espaço de vivência específico ficará condicionada à sua expressa manifestação de vontade".

É interessante que sejam adotas tais medidas nas penitenciarias, pois amenizaria consideravelmente os preconceitos e abusos sofridos pelos LGBTQIA+ condicionados ao cárcere, não seria uma forma de isolar ou segrega-los, mas um meio de prover maior segurança para o cumprimento da pena em condições dignas.

\subsection{Diagnostico Nacional do Tratamento Penal dos LGBTQIA+ nas Prisões do Brasil}

Recentemente o Governo Federal publicou um Documento técnico contendo o diagnóstico nacional do tratamento penal de pessoas LGBTQIA+ nas prisões do Brasil, através do Ministério da Mulher, da Família e dos Direitos Humanos pela Secretaria Nacional de Proteção Global em seu Departamento de Promoção dos Direitos de LGBTQIA+.

Com a finalidade de produzir dados para formular um mapeamento da população LGBTQIA+ privada de liberdade, foi enviado um questionário online para as administrações penitenciarias estaduais, tal feito, em parceria com o Departamento Penitenciário Nacional. O questionário formado por quatro questões básicas, tais como a Identificação, Estrutura, Celas LGBTQIA+' e o Perfil desta população.

De 1449 unidades prisionais, apenas 508 responderam ao questionário informando os respectivos dados solicitados, a partir disto, observa-se a grande abstenção e resistência apresentada pelos administradores das penitenciarias em produzir dados relativos ao encarceramento dos apenados LGBTQIA+ (BRASIL. Ministério da Mulher e dos Direitos Humanos: Documento técnico contendo o diagnostico nacional do tratamento penal dos LGBT nas prisões do Brasil, 2020).

Conforme exposto, os dados finais do questionário das 508 unidades prisionais que responderam, apenas 106 unidades contem Celas/Alas especificas para a população LGBTQIA+, e curiosamente foram apenas as masculinas que indicaram a existência de um local designado para realizar o devido acolhimento para os homossexuais, 
bissexuais, travestis, mulheres trans e até mesmo os heterossexuais que mantém relações afetivas com essa população.

Se torna claro a observação de que, conforme já exposto sobre a "bomba de testosterona", bem como os discursos voltados a marginalidade serem coisas de "macho", os estigmas e preconceitos mais severos apenas nas penitenciarias masculinas, fato este que necessariamente faz com que as prisões disponham de um espaço de vivência especifico, ao qual dentre as cadeias que responderam o questionário, nenhum complexo prisional feminino dispõe de um espaço exclusivo apenas para os LGBTQIA+, isto pelo fato de que as mulheres possuem uma melhor convivência com eles.

O documento possui uma tabela em que expõe um quantitativo de Celas/Alas LGBTQIA+ por Estado, ao qual se verifica o seguinte: O Sudeste possui 442 unidades e destas apenas 56 possuem uma Celas/Alas especifica, totalizando 52,8\%. Enquanto que a Região Nordeste possui 431 unidades onde 27 contém Celas/Alas especificas, formando 25,5\%. A Região Centro-Oeste possui 215 unidades prisionais e destas apenas 16 contém uma Celas/Alas especifica, somando um total de 15,1\%. Seguido pela Região Sul que das suas 177 unidades apenas 6 possui uma Celas/Alas especificas, somando $5,7 \%$. Já a Região Norte é a que tem uma menor divisão de Celas/Alas especificas, visto que de 184 unidades, apenas uma (1) possui o local para o acolhimento desta população, somando assim 0,9\%. (BRASIL. Ministério da Mulher e dos Direitos Humanos: Documento técnico contendo o diagnostico nacional do tratamento penal dos LGBT nas prisões do Brasil, 2020).

De acordo com o relatório, nas unidades que responderam o questionário, existem nas penitenciarias masculinas um total de 1.333 gays, 572 bissexuais, 455 travestis e 163 transsexuais. Vale destacar que, conforme expõe o relatório, estima-se que existam mais pessoas LGBTQIA+ do que as declaradas, afinal, por participarem do grupo vulnerável da penitenciaria, os indivíduos possuem certo receio em declarar a sua sexualidade. Ademais, verificou-se que, a maior parte dos autodeclarados encontra-se nas penitenciarias que tem uma cela/ala específica. (BRASIL. Ministério da Mulher e dos Direitos Humanos: Documento técnico contendo o diagnostico nacional do tratamento penal dos LGBT nas prisões do Brasil, 2020). 
Ademais, destaca-se que os dados expostos no gráfico 18 do relatório supra citado expõe os tipos criminais praticados pelos LGBTQIA+, e ao analisar o quadro dos transsexuais e travestis, as maiores porcentagens se dá com os crimes de roubo (38,5\%) e tráfico (34,6\%), esses dados apenas corroboram com o que foi exposto nesta pesquisa, visto que, refere-se a marginalização social imposta a esses indivíduos, ao qual, forçadamente, na maioria das vezes precisam ingressar no mundo do crime para sobreviverem. (BRASIL. Ministério da Mulher e dos Direitos Humanos: Documento técnico contendo o diagnostico nacional do tratamento penal dos LGBT nas prisões do Brasil, 2020).

Em suma, uma solução adequada para tentar, de certo modo, garantir com mais efetividade a garantia da dignidade humana para essa população seria a priori, a criação de uma cela/ala específica, visto que, as próprias unidades prisionais já seguem essa linha de raciocínio, não ao que tange aos LGBTQIA+, mas ao se tratar de organizações criminosas, onde as administrações visando evitar os conflitos acabam dividindo a unidade prisional de modo que, separe os indivíduos de acordo com a sua faç̧ão.

Não se pode observar, nem sequer utilizar essa separação como uma forma de exclusão dos LGBTQIA+, afinal, ela deve ser feita para que esses indivíduos se sintam mais à vontade, estando com outros de igual identidade de gênero, com os seus semelhantes, algo que, notadamente os traz mais conforto, segurança e, sobremaneira, propicia uma melhor integração e um cumprimento de pena mais digno, sem sofrer ameaças ou serem utilizados de forma que confronte a ideia kantiana da dignidade humana, ou seja, como um meio.

Para assegurar um efetivo e digno encarceramento, é inevitável e inegável que, além de separa-los em uma cela/ala especifica, as unidades prisionais busquem capacitar e instruir os seus agentes penitenciários, afinal, de nada vale separa-los da parte central, ao qual estão os outros detentos, e deixarem a mercê de agentes munidos de preconceitos e estigmas, capaz de serem ainda mais cruéis que os próprios detentos da "bomba de testosterona".

A dignidade humana conforme já exposta nesse trabalho é inerente a todos os seres humanos, no entanto, observa-se que o Estado tem certa dificuldade de incentivar, criar e garantir determinados direitos fundamentais a grupos minoritários, 
motivo este que, em se tratando do Brasil, todos os direitos garantidos aos LGBTQIA+ são frutos de decisões da Suprema Corte, que visa uma maior efetividade dos direitos e garantias fundamentais.

\section{CONSIDERAÇÕES FINAIS}

Visto o exposto, cabe destacar que a dignidade humana constitui um dos fundamentos do Estado Democrático de Direito, apesar das constantes violações, ela após uma longa evolução em seu conceito, hoje encontra-se com status de princípio constitucional.

$\mathrm{Na}$ dificuldade de um consenso sobre o real conceito da dignidade humana, Barroso (2010) expõe três elementos essenciais que ajudam a obter uma melhor compreensão sobre a dignidade do homem. São eles: O valor intrínseco; A autonomia de vontade; e $O$ valor social da pessoa humana.

Ao avaliarmos a situação de um indivíduo LGBTQIA+ no sistema prisional brasileiro, logo torna-se evidente as violações que este sofre em detrimento do cerceamento não apenas de sua liberdade, no entanto, de todo o contexto que o priva de autodetermina-se, e de ações estatais e de outros apenados que ferem o valor intrínseco dos apenados que fogem da dita heteronormatividade acometidos na "bomba de testosterona".

Em uma tentativa de reduzir as desigualdades e suprir a segurança dos indivíduos LGBTQIA+ dentro dos cárceres, criou-se a Resolução conjunta de $n^{\circ} 1$ em 15 de abril de 2014, no entanto, observa-se que até o momento apenas um número irrisório de penitenciárias adotam e põem em prática aquilo que foi estabelecido, fato este comprovado pelo relatório publicado pelo Ministério da Mulher e dos Direitos Humanos em um Documento técnico contendo o diagnóstico nacional do tratamento penal dos LGBTQIA+ nas prisões do Brasil em 2020, que expôs um número minoritário de penitenciarias que adotam uma cela/ala específica para eles.

A situação de vulnerabilidade está presente em toda a vida do LGBTQIA+ e a omissão do Estado é completamente lesiva para a vida destas pessoas, uma vez que, não sendo suprida essa questão legal para assegurar direitos básicos a esta população, elas serão mortas, discriminadas e excluídas de uma vida digna. Ademais, mesmo considerando as penitenciarias como um "Estado de coisa inconstitucional", conforme 
se foi aludido na ADPF de $n^{\circ} 347$, não se pode ignorar a urgência e obrigação dos entes públicos de viabilizarem a amenizarem as violações de direitos resultantes do encarceramento.

O Ministério da Mulher e dos Direitos Humanos publicou um documento técnico inédito contendo o diagnóstico nacional do tratamento penal dos LGBTQIA+ nas prisões do Brasil em 2020, e este foi de suma importância para que viabilizasse a produção de um perfil dessas pessoas que fazem parte do cárcere, pois antes deste documento, os dados eram escassos, além da vulnerabilidade, se impõe a eles a invisibilidade.

O documento apresenta dados concisos, mas imprecisos sobre o encarceramento dos LGBTQIA+, isto pelo fato de que nem todos se sentem seguros em revelar sua sexualidade dentro dos cárceres para que não sofram represálias internas, pois conforme exposto neste trabalho, o homem precisa ser "macho" para ser aceito no mundo da criminalidade.

Em verdade, parte do corpo social está envolvida em uma onda de falso moralismo, onde "faça o que eu digo, mas não faça o que eu faço", com valores e pensamentos que não mais podem ser aceitos no século que vivemos, pois a idade das trevas ficou no passado, e o homem precisa aprender a se tornar responsável pelas próprias ações, sem querer encontrar no divino justificativa para os seus preconceitos.

O Estado, sobretudo, precisa desprender-se destes preceitos éticos e morais que envolvam a discriminação e exclusão de grupo minoritários com base em argumentos não laicos, pois os governantes devem priorizar sempre o bem da coletividade e conduzir o país de modo que venha a garantir direitos e não violações a dignidade das pessoas.

\section{REFERÊNCIAS}

BRASIL. Supremo Tribunal Federal. MC - ADPF № 347, Relator Min. Marco Aurélio, julgado em 09 de setembro de 2015. Disponível em: http://redir.stf.jus.br/paginadorpub/paginador.jsp?docTP=TP\&doclD=1030066 5. Acesso em: 10 mai. 2020.

Bruna G. Benevides; Sayonara Naider Bonfim Nogueira. DOSSIÊ: ASSASSINATOS E VIOLÊNCIA CONTRA TRAVESTIS E TRANSEXUAI NO BRASIL EM 2018. Brasil, 2019. Disponível em: https://antrabrasil.files.wordpress.com/2019/01/dossie-dosassassinatos-e-violencia-contra-pessoas-trans-em-2018.pdf. Acesso em: $08 \mathrm{dez}$ 2019. 
BUTLER, J. Problemas de gênero: feminismo e subversão da identidade. Tradução de Renato Aguiar. Rio de janeiro: Civilização Brasileira, 2003.

CAPPELLARI, Mariana Py Muniz. Gêneros Encarcerados: LGBTQIA+s no Sistema Prisional Brasileiro. 2018. Revista Eletrônica da Faculdade de Direito da Universidade Federal de Pelotas (UFPel), 2018.

COMPARATO, Fábio Konder. A afirmação histórica dos direitos humanos, 2003, São Paulo, 2003.

Conselho Nacional de Política Criminal e Penitenciária (CNPCP); Conselho Nacional de Combate à Discriminação (CNCD/LGBTQIA+): Resolução Conjunta $n^{\circ} 1,15$ de abril de 2014.

FACHIN, Melina Girardi. Fundamentos dos direitos humanos: teoria e práxis na cultura da tolerância. Rio de Janeiro: Renovar, 2009.

FOUCAULT, Michel. Microfísica do Poder. Tradução e organização Roberto Machado. 7.ed. Rio de Janeiro: Graal, 1979. p. 295.

GUERSON, Mariana Silva. O Retrato da vulnerabilidade dos Homossexuais no sistema Carcerário Brasileiro. 2018. 27f. Trabalho de Conclusão de Curso - Universidade Federal de Juiz de Fora, Juiz de Fora, 2018.

LAGO, Nátalia; ZAMBONI, Marcio. Políticas sexuais e afetivas da prisão: Gênero e sexualidade em contextos de privação de liberdade. In: Anais do $40^{\circ}$ Encontro Anual da Associação Nacional de Pós-Graduação e Pesquisa em Ciências Sociais.

LIMA JÚNIOR, Luiz Pereira de. Sexualidade: um mapa em rascunho. João Pessoa: Editora da UFPB, 2012.

Luís Roberto Barroso, A dignidade da Pessoa Humana no Direito Constitucional Contemporâneo: Natureza Jurídica, Conteúdos Mínimos e Critérios de Aplicação. Versão Provisória para debate público. Mimeografado, dezembro de 2010.

Ministério da Mulher, da Família e dos Direitos Humanos (Departamento de Promoção dos Direitos de LGBTQIA+). LGBTQIA+ nas prisões do Brasil: Diagnóstico dos procedimentos institucionais e experiências de encarceramento. Diretora: Marina Reidel. Consultor: Amilton Gustavo da Silva Passos. Brasília, 2020.

NOGARE, Pedro Dalle. Humanismo e anti-humanismo: introdução a antropologia filosófica, 1990.

PECES-BARBA MARTÍNEZ, Gregorio. La dignidad de la persona desde la filosofia del derecho, 2003.

Princípios de Yogyakarta, 2006. 
SARLET, Ingo Wolfgang. Dignidade da pessoa humana e direitos fundamentais na Constituição Federal de 1988, 2012.

SESTOKAS, Lucia. Cárcere e Grupos LGBTQIA+: Normativas nacionais e internacionais de garantias de direitos. Instituto Terra, Trabalho e Cidadania. 01 abr 2015.

ZAMBONI, Marcio. $\mathrm{O}$ barraco das monas na cadeia das coisas: notas etnográficas sobre a diversidade sexual e de gênero no sistema penitenciário. In: ARACÊ - Direitos Humanos em Revista, ano 4, número 5, 2017. 


\title{
CAPÍTULO XVI
}

\section{"LIBERDADE CAÇA JEITO": UMA PERSPECTIVA PSICANALÍTICA SOBRE AS NOVAS FORMAS DE SUBJETIVAÇÃO DA SEXUALIDADE E DO GÊNERO}

\author{
Andrea Maria de Senna Marques ${ }^{1}$ \\ Tácito Saraiva de Sousa Lucena ${ }^{2}$
}

\begin{abstract}
${ }^{1}$ Psicóloga e Mestre em Psicologia pela Universidade de Fortaleza (UNIFOR). Formação em Psicanálise pela Escola Paulista de Psicanálise (EPP). Docente de cursos de Graduação e Pós-graduação. Psicóloga Clínica com atuação em atendimentos de adolescentes, adultos e casais na perspectiva psicanalítica. Supervisora clínica. Pesquisadora em Psicanálise pelo Instituto de Altos Estudios en Psicología y Ciencias Sociales (IAEPCIS), Buenos Aires, Argentina. Membro fundadora do Espaço Psicanalítico Latino-Americano.

2 Psicólogo, Especialista em Clínica Psicanalítica pelo Centro Universitário Estácio do Ceará.
\end{abstract}

\section{RESUMO}

A sexualidade humana sempre tem sido um dos temas mais conturbados para a cultura. Há uma tentativa massiva de normatizá-la e enquadrá-la como algo fixo e importante para a perpetuação de uma "sociedade sadia". Movimentos sociais emergindo com discussões que põem em xeque a visão tradicionalista, trazem para o campo do saber as possibilidades da existência humana e as potencialidades do próprio corpo. 0 presente artigo pretende desenvolver uma análise sobre o esmiuçamento da sexualidade humana pela psicanálise freudiana e lacaniana e como é possível, a partir dela, pensar sobre as atuais e emergentes questões de gênero, considerando a dimensão histórica e cultural.

Palavras-chave: Sexualidade. Gênero. Psicanálise. Subjetividade.

\section{INTRODUÇÃO}

A Psicanálise tem se debruçado, década após década, a desvendar as nuances inconscientes que constituem o sujeito e, deste, os mecanismos que o operam junto com a sua invariável contribuição no contexto em que se insere. A sexualidade participa de todos esses mecanismos que circundam a personalidade e marcam a nossa presença no mundo coordenados por exigências sociais que se colocam em clamor de uma postura narcísica que diga algo sobre como se deve ser no mundo e o que desejar, prevalece-se um Eu Ideal que livre o sujeito da angústia da castração e um Ideal de Eu comprometido com a rigidez moralista da cultura. Desse modo, a tendência neurótica para se sair de uma crise é fazer com o Ideal de Eu se satisfaça com o Eu Ideal. 
Na contemporaneidade, há um leque gigantesco de discussões sobre os limites do Estado sobre o corpo e o desejo, assim como um vislumbre diversificado das formas de ser no mundo. Propiciado pela ascensão dos movimentos sociais feministas e de diversidade sexual, sexualidade e gênero ganharam papéis centrais nas discussões políticas, religiosas, familiares, laborais e, no meio disso tudo, há o cunho individual em que se fundamentam as ideias do que é um e outro, assim como o seu ideal. Nesse ponto, a psicanálise tem muito a falar e, como sempre, desvendar.

Desde as primeiras proposições teóricas, a psicanálise pôs a mulher num papel central com a descoberta da histeria e discorreu sobre ela, à priori, como sendo uma leitura da sexualidade feminina, ou sexo feminino, ou mulher. Discussões se geraram sobre o tema até que o próprio Freud considerou a ideia de que estrutura psíquica não é rigidamente estática e determinante pelo componente anatômico e biológico.

Aparentemente uma constatação simples que, na verdade, trouxe uma revolução para se pensar a sexualidade humana sobre os vieses que, anteriormente, não se dispunham como possíveis. Afinal, quem agarrava essa cadeia significante sobre 0 humano e sua sexualidade, até então, eram três instâncias: o Estado, a Igreja e o discurso médico rudimentar. E hoje, do que se trata a sexualidade humana e o gênero? Essas concepções falam sobre a mesma coisa ou falam de algo a mais? Como a noção de identidade e corpo aparecem no psiquismo?

Queremos, no entanto, discorrer sobre como a sexualidade é entendida à luz da psicanálise freudiana e lacaniana e, a partir dela, como o gênero aparece, seja numa perspectiva individual, seja numa ideia de como a cultura o compreende e, à rigor, o impõe enquanto Ideal de Eu atrelado ao conceito biologizante da sexualidade. Utilizando-se disso, nos questionaremos sobre como a concepção subjetiva e cultural de gênero se amplia e se dilui no corpo e no desejo.

\section{A DESCOBERTA DA SEXUALIDADE EM FREUD}

Falar de sexualidade, em Freud, é falar também sobre o conceito de pulsão que trouxe um norte a essa nova compreensão àquela época. Honda (2011) pontua que o conceito de pulsão aparece como um "conceito-limite ou conceito-fronteiriço" (p. 406), estando situado no limite entre o psíquico e o somático. A libido, por sua vez, é a energia 
da pulsão, e quem viabiliza a satisfação, mesmo que parcial, ao alcançar seu destino. Podemos fazer uma analogia entre psicanálise e arte que são frequentes para discorrer sobre a sexualidade. É o que fez Auguste Rodin, o artista das esculturas em "carne viva", no côncovo das mãos se deposita a potência da palavra que é redita:

Fotografia - Auguste Rodin. Mãos de Amantes,1904.

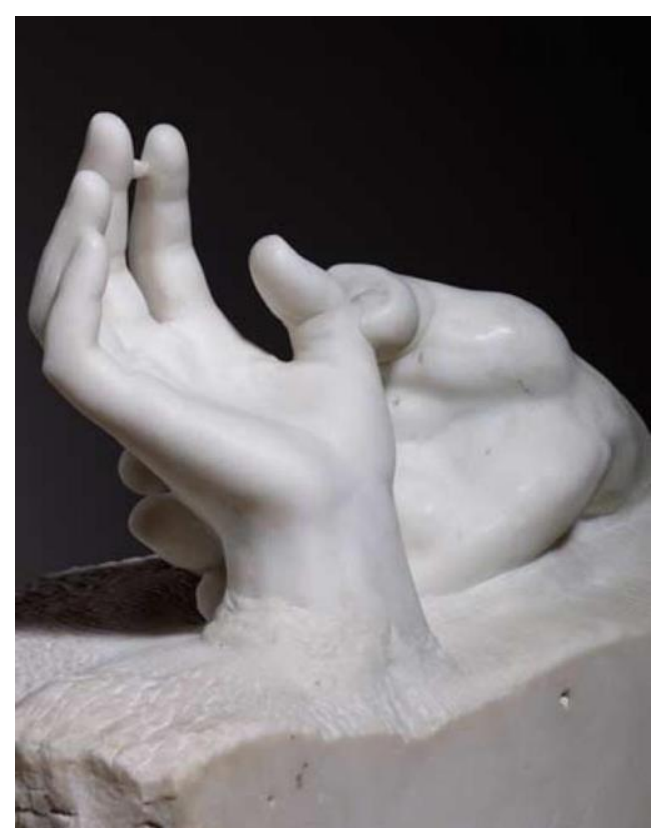

Fonte: Museu Rodin, Paris

A sexualidade, como o senso comum o compreende, até hoje é um tabu e, por isso, tratado com certa marginalidade. Pensar isso nos dias de hoje, invariavelmente, nos leva à época de Freud, em que o discurso médico se baseava pura e simplesmente numa concepção biologizante, muitas vezes corroborando com o que a Igreja dizia. Esse fato nos evidencia o quanto de euforia não deve ter causado na época seus estudos e não de forma positiva.

Coutinho Jorge (2007, p. 31) afirma que, "antes de Freud, não há propriamente um conceito clínico sobre a sexualidade". Desse modo, abria-se um amplo leque de possibilidades conceituais, o que diminuía ainda mais as chances de algum investigador oferecer uma noção que compreendesse a magnitude do tema, mesmo que bem fundamentado. Uma das grandes tentações que, na época de Freud, se cedia era a de patologizar a sexualidade. Essa ideia traz à tona que, qualquer expressão sexual fora do 
convencional era considerado como doença e, logo, buscado tratamento supostamente adequado para a sua aparente cura.

Freud adentra de vez à concepção de sexualidade em 1905 com sua obra "Três ensaios sobre a teoria da sexualidade". Amaral (1995) aponta que essa obra não tem uma perspectiva conclusiva, deixando abertas várias questões e, algumas delas, divergentes, como a tese sobre pulsão sexual. Freud, nessa obra, já trouxe a noção da existência de uma sexualidade infantil através da presença de tendências perversas enquanto fator constitutivo do sujeito.

Amaral (1995) ainda discorre que, mesmo não havendo uma menção direta ao narcisismo, conceito posterior, há uma gama de fatores que discutem sobre o surgimento do sujeito psíquico e o autoerotismo se faz presente nesse ponto. Freud identificou que a sucção voluptuosa do bebê marca a expressão dessa sexualidade. Como ele ainda não conhece nenhum objeto sexual, é autoerótico, acaba dominado por uma zona erógena. A libido é voltada para si. Da mesma forma discreta, nessa obra é constatável, além da presença da ideia de uma sexualidade infantil oral através da sucção e voracidade, a sexualidade anal, através dos excrementos.

No terceiro ensaio, Freud traz a concepção de que a sexualidade adulta deriva de resquícios da sexualidade infantil. Se na infância há destinos bastante específicos, na puberdade há uma subordinação dessas zonas erógenas à genital e, com isso, há uma obtenção constante e massiva de prazer, onde Freud, à priori, considerou ser de cunho reprodutivo, o que ratificava a normatividade da época.

Freud (2006) sinaliza que na puberdade a sexualidade encontra o objeto para o qual foi preparado durante a infância. Posteriormente, abriga a ideia de que a escolha objetal trilha o caminho deixado pela relação mãe-bebê. É possível pensar, então, que o primeiro objeto sexual do bebê é o seio materno, visto que a satisfação sexual estava atrelada à alimentação, desse modo, a pulsão encontrou seu objeto fora do próprio corpo.

Observa-se que a pulsão não está estritamente presente desde o início, o autoerotismo ganha outro contorno quando deixa de ser arquitetado como condição originária, sendo formulado na relação. "Assim, não restam dúvidas de que encontrar o objeto é, reencontrá-lo". (WARMLING, 2019, p. 33) 
Freud atravanca as concepções da época ao constatar que a sexualidade não é uma prerrogativa da vida adulta e utilizada estritamente para os fins biologizantes e organicistas a que se propunha. Não é algo dominável, mas que escapa, escorrega. Vieira (2019) pontuou que "fazemos sexo para tudo, até para procriar". A vida adulta, portanto, é marcada por esse fator de reencontro do objeto sexual perdido na infância. Esse delimitador marca todas as relações afetivas que o sujeito se depara ao longo da vida.

A sexualidade, em Freud, concebe uma questão muito maior, sendo marca de expressividade, saúde, patologia e base para a constituição psíquica. Ela parte de um desejo incestuoso cuja origem se encontra na pulsão e que nunca é satisfeito, ou cuja satisfação sempre é parcial, pois essa tendência ao gozo absoluto, invariavelmente, implica na morte.

Freud (2006) postula que o impulso sexual é constituído de outros diversos impulsos parciais que se dispõem às mais diversas configurações de prazer em diferentes partes do corpo. Amparados pelas zonas erógenas, o impulso parcial pode se espalhar pelo corpo, pois não possui um objeto fixo.

Ceccarelli (2017, p. 137) afirma que "toda atividade sexual testemunha um percurso pulsional particular, traçada pela singularidade da história de cada um, o que impossibilita a tentativa de criação de uma "norma sexual'". Compreendemos, a partir dessa consideração, que a normatividade da vida sexual é um erro grotesco e pretensioso, pois a diversidade psíquica que opera nesse mecanismo pulsional é demasiadamente gigante para ser ignorada ou enquadrada num nível tão raso quanto o perpetrado culturalmente.

Coutinho Jorge (2010, p. 117) diz que "o inconsciente é exatamente o verdadeiro intermediário entre o somático e o psíquico. Talvez, o missing link, o elo perdido, tão procurado". E como tal, é indomável, irrefreável, posto que seu conteúdo guarda os registros do material reprimido que o sujeito vivenciou e recalcou. Desse modo, o sujeito está fadado a confrontar o retorno do recalcado que, seguindo os impulsos do inconsciente, tende a escapar. É ele quem esconde os porquês de todas as ações humanas e rege as preferências que se adota durante a existência.

Essas idéias [sic] são registradas no inconsciente, passando a integrar o seu sistema de memória e condenando o eu, doravante, a experimentar os seus retornos sucessivos como um corpo estranho 
incompatível com a sua consistência imaginária. O recalque não elimina a representação indesejável, mas simplesmente isola-a psiquicamente. As idéias[sic] de caráter aflitivo passam, desde então, a formar um grupo associativo separado da consciência, organizandose de acordo com leis associativas diversas daquelas que regem o eu consciente, condenando-o a uma luta permanente contra o retorno do recalcado em derivados substitutos do inconsciente, sob a forma de uma tenaz resistência. (BARATTO, 2009, p. 83).

Atuando nessa fronteira, procura uma forma de se evadir, de gritar, de evidenciar sua presença e, a marca que ele mais ratifica é esta: a sexualidade humana é múltipla, diversa, sem destino específico, latente, mas sempre pronta a mostrar que, mesmo conflitante, é maleável. Se o sujeito é, sobretudo, sexual, a via régia dessa manifestação está em toda parte, no corpo, na sublimação. Mendes (2011) pontua que, ligada a uma origem sexual, a libido pode criar caminho em atividades não sexuais, ou seja, sublimatórias, que são cultural e socialmente aceitas, como a arte, o esporte, a ciência.

\subsection{Contribuições freudianas e lacanianas sobre gênero}

Ceccarelli (2017) defende que há um consenso de que Freud não desenvolveu uma teoria de gênero, no entanto, seus estudos não o excluem. O mesmo autor faz um breve apanhado sobre as menções que Freud faz à questão do gênero em sua obra. Em Sobre as teorias sexuais infantis de 1908, Freud considerou que a diferença anatômica seria secundária e o gênero seria a base de uma distinção identitária.

Nesse sentido, o gênero viria primeiro, embora seja o sexo que o determine: é a partir da percepção anatômica que o gênero é atribuído ao recém-nascido. Vemos que, para Freud, o sexo é natural: a anatomia é o destino. (CECCARELLI, 2017, p. 141)

Freud considerava que o gênero, enquanto referência advinda do outro, se apresentava de forma natural, de acordo com o marcador biológico determinante para tal. Mas não reduz o gênero à presença de vagina e/ou pênis. Para ele havia outros fatores que localizavam o indivíduo no gênero masculino ou feminino, sendo a anatomia apenas uma forma de destinar os impulsos sexuais.

Ceccarelli (2017) ainda retorna para 1905, em Três Ensaios, onde Freud escreveu sobre a "Teoria popular sobre pulsão sexual" (de gênero); em 1914, sobre o Narcisismo, Freud propõe pesquisar esse investimento sexual no próprio corpo por três 
vieses: da psicose, da doença orgânica/hipocondria e da vida amorosa entre os sexos (gêneros).

A construção realizada por Freud acerca de gênero nos leva a uma concepção ainda informe sobre a grandeza que o tema possui na atualidade. Certamente, vivenciando nossa época e discutindo com os movimentos sociais, o gênero seria um de seus objetos de estudo a fim de mergulhar nas tramas inconscientes que estão por trás desse novo paradigma.

No entanto, Freud (2006) não chega a ser raso quando deixa explícito em Três Ensaios sobre a Teoria da Sexualidade que o masculino e o feminino podem ser pensados sob três vieses: o de atividade versus passividade, o biológico e o sociológico. O autor traz para o foco o enigma que a ciência ainda não conseguiu dar conta, seja devido à sua amplitude, seja pela inconsistência de saberes ou pela maleabilidade que a sexualidade como um todo apresenta.

É indispensável deixar claro que os conceitos de "masculino" e "feminino", cujo conteúdo parece tão inambíguo à opinião corriqueira, figuram entre os mais confusos da ciência e se decompõe em pelo menos três sentidos. Ora se empregam masculino e feminino no sentido de atividade e passividade, ora no sentido biológico, ora ainda no sentido sociológico. $O$ primeiro desses três sentidos é o essencial, assim como o mais utilizável em psicanálise. A isso se deve que a libido seja descrita no texto como masculina, pois a pulsão é sempre ativa, mesmo quando estabelece para si um alvo passivo. 0 segundo sentido de masculino e feminino, o biológico, é o que admite a definição mais clara. Aqui, masculino e feminino caracterizam-se pela presença de óvulos e espermatozóides, e pelas funções decorrentes deles. A atividade e suas manifestações concomitantes desenvolvimento muscular mais vigoroso, agressividade, maior intensidade da libido - costumam ser vinculadas à masculinidade biológica, embora essa não seja uma associação necessária, já que existem espécies animais em que essas propriedades correspondem antes na fêmea. $O$ terceiro sentido, o sociológico, extrai seu conteúdo da observação dos indivíduos masculinos e femininos existentes na realidade. Essa observação mostra que, no que concerne ao ser humano, a masculinidade ou a feminilidade puras não são encontradas nem no sentido psicológico nem no biológico. Cada pessoa exibe, ao contrário, uma mescla de seus caracteres sexuais biológicos com os traços biológicos do sexo oposto, e ainda uma conjugação da atividade e da passividade, tanto no caso de esses traços psíquicos de caráter dependerem dos biológicos, quanto no caso de independerem deles (FREUD, 1905/2006, p. 207). 
Freud esboça a forma como a linguagem se ampara no gênero para cumprir com uma designação inflexível. Há algo que toma outro algo por referência. Por uma questão de tradução, não temos acesso ou conhecimento para considerar as palavras e significantes que circundam os escritos freudianos. Na linguagem, a binaridade do gênero se desloca para a posição ativa ou passiva, sendo a ativa constituída pelo masculino e a passiva pelo feminino. No entanto, vemos que o Dicionário da Língua Portuguesa classifica as palavras "ativa" e "passiva" enquanto substantivos masculino e feminino ao mesmo tempo, a definir pelo contexto.

Além desse dado que media as obras freudianas traduzidas para a língua portuguesa, há também um componente que ele mesmo recria em seu texto, que é a compreensão de que "ativo e passivo" se tornam sinônimos de macho e fêmea quando considerado o conteúdo orgânico, como hormônios, musculatura, apetite sexual. Embora retorne ao ponto de que há espécies na natureza a quem essa máxima não se aplica, visto que se invertem, é possível observar que o tom semântico é o mesmo. Gênero e linguagem se vinculam e são indissociáveis. Freud não se ateve à gênese da questão, mas deu o primeiro passo para que outros teóricos se aprofundassem.

O terceiro viés para gênero o qual Freud explana trata da questão sociológica. O autor traz a ideia de que o masculino e o feminino são plurais e não se apresentam no psiquismo ou na biologia de forma integral, mas há uma mistura das conjunturas sexuais masculinas e femininas no mesmo sujeito, assim como uma junção da atividade e da passividade que podem derivar ou não do biológico.

Lacan (2008) defende que no psiquismo não existe algo em que o sujeito se ancore para se localizar na binaridade masculino-feminino. Para ele, tanto as atribuições sociais como as individuais de gênero são dadas através do outro, enquanto função constitutiva do sujeito. Invariavelmente, o outro está banhado pela cultura em que se insere e é dela que ele herda essa tendência à manutenção do status quo.

Lacan, ao tocar nesse ponto, traz implicitamente que é do outro que herdamos nossas referências, tão importantes e balizadoras na construção do psiquismo. É a partir do outro e da capacidade do sujeito de dissociar dele que se estabelecem as construções subjetivas constitutivas, o desejo, como parâmetro para pensar as coisas e questionálas. Se o sujeito é banhado de significantes pelo outro, é a partir dele - e somente dele - que o sujeito é inserido na linguagem, na falta, no desejo. 


\subsection{Gênero e identidade}

Cossi $(2019$, p. 310) lembra que "o processo de constituição do sujeito como homem ou mulher, na trama edípica, é histórico ou cultural, portanto, não predeterminado". A ideia de gênero, definido ou classificado pelo arranjo anatômico do bebê, serve a uma composição identitária e é dela, subjugada. Há algo muito maior que se coloca para além da questão do gênero, que é a questão da identidade como unidade representada na pluralidade.

Starnino (2016) cunhou que estamos destinados às inúmeras possibilidades de identificação que temos ao longo da vida. Primeiro no seio familiar, depois nas instituições às quais fazemos parte, como escola, universidade, comunidade, grupos, igreja, etc. O sujeito é apresentado aos ideais identitários desde cedo e, a partir dele, molda seu desejo em resposta à essa demanda externa.

As escolhas inconscientes, segundo Lacan (2016), respondem ao eu ideal enquanto instância do narcisismo primário onde a identidade, ainda não maturada, torna-se um objeto da expectativa do outro, ou seja, a criança atende, inconscientemente, às demandas inconscientes de seus pais. Após o Complexo de Édipo, surge o substituto simbólico à essa instância imaginária, o ideal de eu. Nele, emergem figuras identificatórias de fora do seio familiar, mas que partem das mesmas referências, como professores, mestres, figuras de poder, autoridade, etc. É a partir do ideal de eu, enquanto ideal regulador, que os laços de afeto se apresentam, visto que as estruturas de admiração permitem idealizar como o sujeito pode responder ao desejo, embora se mostre como instância inatingível. Portanto, a identidade do sujeito sempre será faltante, escassa frente às regulações do Ideal de Eu.

Segundo Chauí (2001), o conceito de inconsciente, pressuposto psicanalítico, desconhece os valores moralistas que regem qualquer sociedade, portanto, a compreensão normatizadora da sexualidade e do gênero não só é, por ele, ignorada, como é ampla e incontrolável. O gênero do sujeito, forma de expressão da identidade e da própria sexualidade, também é tecido pelas leis inconscientes, que não considera sua referência anatômica e cultural.

Jorge (1997) infere que o sujeito habita no hiato da designação binária da sexualidade, isto é, entre homem e mulher. Por isso, o sujeito é o próprio sexo ao invés 
de, deste, ser detentor. Esse pensamento rompe com a concepção de haver dois polos e que o sujeito se localiza num deles, visto que o inconsciente não se compromete com essa dimensão histórica e cultural enrijecida de um suposto lugar do desejo.

Lima e Belo (2019) apontam que há a possibilidade de um diálogo entre Jean Laplanche e Judith Butler ao discorrer sobre o banho de significantes ou as mensagens enigmáticas que o bebê recebe do adulto. Quando o adulto transmite para a criança seus desejos inconscientes, há um investimento narcísico sendo repassado. Aqui está sendo apresentada também a significação de gênero a esse bebê, que irá cunhar o seu entendimento sobre a sua identidade e o seu próprio corpo, visto que a criança ainda está numa posição passiva frente ao desejo do outro.

Destacando os conceitos de Jean Laplanche e Paulo de Carvalho Ribeiro, Lima e Belo (2019) vem falar que a identificação passiva é realizada por aqueles que circundam o infante, excepcionalmente pelos seus cuidadores, o socius, ao invés de pelo próprio sujeito que ainda não maturou o suficiente para responder ativamente à essas demandas, seja confirmando-as, negando-as ou reelaborando-as. Isto é, mãe, pai, irmãos, tios, avós, cuidadores em geral tem total contribuição nesse processo identificatório.

Assim, na medida em que se tem no colo um bebê identificado 'pelo adulto' como menino, os tratamentos, desejos e fantasias endereçados a ele serão radicalmente diferentes daqueles dados a um bebê identificado como menina, pelo valor fantasmático que cada gênero ganha na cultura. (LIMA \& BELO, 2019, p. 6)

O significante, puro e simples, não é determinante. Há algo mais complexo que se infere na linguagem e nos comportamentos derivados dos circundantes da criança. Se o adulto, quando infante, assimilou parte dos desejos do outro, a outra parte necessariamente fora abandonada e, por isso, recalcada. Os eventos traumáticos do adulto repercutirão invariavelmente na criança que herdará um desejo que é "do outro do outro", pertencente ao próprio cuidador, porém herdado do outro, posto o investimento narcísico que é lançado. 


\section{DISCUSSÃO}

O presente texto nos possibilitou fazer um breve apanhado histórico sobre as concepções de sexualidade e gênero desde Freud e Lacan, até os psicanalistas da atualidade. Através desse apanhado, foi possível dialogar com teóricos que se propõem a desenhar a dimensão histórica, social e cultura acerca da sexualidade humana, identidade e gênero.

Caminhar implica, necessariamente, no avanço da ciência no que diz respeito à ampliação das ideias, mesmo correndo o risco de causar mal-estar na cultura. Outro ponto e que, neste, não podemos ceder é aos avanços em si mesmos, sem referenciais a fim unicamente de balizar uma nova ordem de pensamento social. A falta de referências e testemunho científico, por muito anos, foi a causa da descredibilização dos necessários avanços sociais por parte de setores da sociedade. Nossas investigações, com os à prioris que norteiam, precisam nos deixar atentos a fim de compreender a verdade do que se apresenta a nós, seja na clínica, seja numa leitura da conjuntura social.

As obras freudianas e lacanianas usam o gênero como referência para questões ligadas ao corpo, à sexualidade e à subjetivação, inclusive como objeto de estudo para o desenvolvimento de conceitos tão abissais e fundantes à psicanálise. Freud não faz uma varredura literária acerca disso e, tampouco, procura historicizá-lo. Sua análise se constrói num contexto social tomado pela moralidade, patologização da diversidade e, assim, experiencia as nuances de sua época, rompendo severamente com o pensamento dogmático e científico.

É possível constatar a veemência do inconsciente, seus desdobramentos, sua capacidade de se evidenciar como vivo e pulsante, operado por suas próprias leis. A pulsão, objeto mais plástico da sexualidade humana, é operada pela libido e está aqui presente para testemunhar o atravessamento do sujeito pela cultura e pela linguagem. E é ela também, a cultura, que barra nossos impulsos mais primitivos.

Se por um lado a repressão induz atividades sublimatórias e, por isso, as formas de lidar com a sexualidade ganham performances mais sociáveis, por outro lado ela também tende a normatizar e, consequentemente, patologizar as diversidades sexuais que se apresentam. Chauí (2001) já ressaltou que o inconsciente desconhece e rejeita 
essa formulação, posto que as compreensões sociohistóricas só regem a realidade externa.

Essa construção psicanalítica abre uma desconstrução sociohistórica do que a sexualidade, operada pelo inconsciente, representa e quais os percursos que ela elabora para o seu desenvolvimento. O sujeito, carregado de pulsões, está fadado a ceder aos impulsos sexuais e os destinos pulsionais podem ser variados. Zonas erógenas se estabelecem, processos sublimatórios à posteriori, mas há sempre um empecilho: a impossibilidade de satisfação ou a satisfação parcial.

As novas formas de subjetivação da sexualidade na atualidade compreendem que a escolha do objeto de amor, assim como a compreensão de corpo e gênero, perpassa processos identificatórios que possuem características dinâmicas. Dizer-se que as escolhas possuem caráter consciente seria preconizar um discurso rudimentar que não considera o aparato científico ou metapsicológico dos fatos.

Desde a segunda metade do século $X X$, as disforias de gênero ou inversões sexuais deixaram de integrar o rol das patologias, pautando a diversidade da existência, assim como novas referências sobre o papel das ciências sobre esse tema. Identidade de gênero, orientação sexual, sexo biológico e expressão de gênero passaram a ganhar novos referenciais e conceitos a partir dessas novas configurações. Se outrora predominava uma necessidade de patologizar o que fugisse à regra, nesse novo modelo havia a intolerância que se perpetua até os dias de hoje, principalmente nas sociedades mais religiosas, sobre o reconhecimento dessas diversidades. A sociedade ainda caminha a passos lentos nesse reconhecimento e na garantia de direitos às populações em situação de vulnerabilidade devido às questões sexuais.

Ora, não nos parece uma realidade muito distante. Em 2016, orientado pela base fundamentalista religiosa, foi criado na Câmara dos Deputados brasileira um projeto de lei que propunha o tratamento para a reversão da orientação sexual. Esse dado nos faz pensar sobre o quanto os conceitos freudianos, mais de 100 anos atrás, trouxeram burburinho e estardalhaço científico, social e clérigo à época.

Como na época de Freud em relação à orientação sexual, o consenso geral continua rígido em estreita consonância com a moral sexual: sexo, gênero, desejo e orientação sexual continuam a ser entendidos como características 'naturais' dos indivíduos. (CECCARELLI, 2017, p. 139) 
Vemos que, em Freud, há um rompimento com o pensamento biologizante da época a medida que se discorre sobre os processos inconsciente. Isso nos leva a crer que, em Freud, há, antes de tudo, algo de ordem interna que factualmente é assimilado junto à questão histórica e cultural de gênero: a identidade. Essa, por sua vez, é construída, erigida e arquitetada nos processos infantis como a trama edípica, visto que nela a criança se situa no mundo, de acordo com sua organização interna, desenvolvendo o superego e constituindo um objeto de amor a partir de suas identificações familiares.

A pulsão, objeto mais plástico da sexualidade humana, é a possibilidade de representação do objeto perdido que não tem uma imagem, então pode ser qualquer coisa, por isso nos apropriamos da linguagem, para tentar falar sobre. A linguagem diz que o sujeito sempre tentará dizer algo que não pode ser dito - e nunca será entendido. Se o objeto está perdido para sempre, a fantasia é que dará conta de preencher esse sujeito. A pulsão testemunha o atravessamento do sujeito pela cultura e pela linguagem. E é ela também, a cultura, que barra os impulsos mais primitivos do sujeito, primeiramente utilizando a figura paterna como representante.

Para a psicanálise, não há ideal de eu universalizado, massificado como emprega a cultura, justamente por considerar a dinâmica do inconsciente. $O$ ideal de eu é inalcançável porque é ideal, e é ideal porque é inalcançável. Sempre haverá uma insatisfação, pois, à medida que o sujeito caminha em direção a esse ideal, o ideal dele também se distancia. Enquanto o eu ideal é entendido como uma miragem no narcisismo primário, o ideal de eu é um suporte à essa miragem no narcisismo secundário. Desse modo, cada um tem que se a ver com seu próprio ideal de eu, com seu próprio desejo.

Mudanças no corpo, pequenas ou não, falam de uma insatisfação, uma falta e, à posteriori, um desejo que serve aos impulsos sexuais e que carecem de descarregamento. Se o mundo está mergulhado em possibilidades de existência, concretamente podemos pensar que a liberdade do pensamento trouxe consigo novas formas de aprisionamento. Se para cada falta, um desejo, é verdade também que para cada falta, uma suposta completude que insere o sujeito num ciclo sem fim, haja vista o caráter longínquo do ideal do eu e a impossibilidade de satisfação total. E esse dado, tão 
comum à neurose, remete à elaboração da diversidade de aparatos fantasmáticos que digam: foi tamponado.

Silva e Oliveira (2013) entendem que nos dias de hoje, a busca pela identidade ganhou uma mescla de possibilidades muito forte e que essa busca não está mais no campo interno, sendo refletida no próprio corpo. A indústria da beleza compreendeu isso ampliando o leque de possibilidades e acessibilizando às classes sociais não tão favorecidas. O próprio Estado começou a oferecer alguns procedimentos, desde que ligados à questão de saúde.

A compreensão do corpo foi se ampliando e as pessoas se apropriando de seus corpos com mais afinco. O movimento feminista, vanguardista que é, traz à tona esse debate sobre quem tem a legitimidade do corpo feminino, mais do que a própria mulher. O Estado, supostamente laico, atrelado à Igreja, supostamente cordial, ainda detém muito desse poderio que marca um aprisionamento da mulher e das diversidades sexuais.

Silva e Oliveira (2013, p. 276) falam que "essas demarcações no corpo podem ser chamadas de acoplamentos, visto que se conectam para a produção da identidade". Essas modificações possuem efeito prático no grupo social no qual o sujeito faz parte, para a aquisição de uma posição de destaque e vinculada ao sentimento de aceitação e pertencimento.

Se antes as possibilidades mais prováveis de construção e redescoberta da identidade que se refletiam no corpo eram mudanças mais sutis, como no visual através de um corte ou coloração do cabelo ou estilo de roupa, agora as mudanças ocorrem na própria pele ou dela para dentro. A reelaboração externa, fruto de questões inconscientes, está cada vez menos sutil e isso diz muito sobre como o ser humano tem se dedicado a si mesmo como forma de se experimentar, se reelaborar e se mantendo à serviço do desejo.

O desejo, advento "do outro do outro", que é substancialmente constituído de investimento de ordem narcísica, traça no bebê um caminho para a realização do seu próprio desejo. Atenta às demandas dos cuidadores, através de uma identificação passiva, a criança tomará para si este desejo que, atravessado pela cultura e pela linguagem, se engendra também nas concepções de sexualidade e gênero. 
Butler apud Lima e Belo (2019) também apontará os caminhos para a designação da identidade da criança em função do desejo dos pais. Frases como "Você será a garota que eu nunca fui'; 'Você será o homem que meu marido recusa ser'; 'Você será a garota quando eu precisar que você o seja, e então o garoto quando eu precisar que você o seja'” (BUTLER, 2014, apud LIMA \& BELO, 2019, p. 6-7) concretizam a projeção do desejo dos pais nos filhos. Mas Butler vai além. Mais do que pertencer a um gênero ou detê-lo, a questão é sobre o que o gênero exige da própria criança, o que os pais pedem quando idealizam o lugar do gênero na criança e como esta pode atender a esse desejo.

Ser homem ou ser mulher requer, sobretudo, uma conjuntura fantasmática daquilo que a cultura compreende sobre o gênero. A localização binária de gênero, na infância, serve única e exclusivamente, mas não menos importante, como referências para a sexualidade e para o corpo. No entanto, não se pode deixar de fora o caráter esmagador que essas exigências possuem para a criança que, respondendo ao desejo "do outro do outro" através também dos processos identificatórios, não identifica em si mesma uma formação coesa de identidade no próprio corpo.

O sintoma, enquanto acontecimento do corpo, denota uma posição importante a ser considerada sobre o discurso de "ter um corpo". O "ser um corpo" não se justifica para o homem, uma vez que para a sua identificação é necessário que haja aí uma relação entre o corpo e os seus significantes. (SOUTO et. al., 2016, p. 193)

Por assim dizer, possuir um corpo pressupõe e confirma a existência de instâncias superiores que regem o ordenamento psíquico, onde há algo maior - o inconsciente e seus mecanismos - imperando sobre o caráter identitário e sexual do sujeito. É ponderável pensar também que, na relação entre o corpo e a subjetividade, é necessária uma convergência, um diálogo para que se afirme identitariamente a posição do sujeito frente ao desejo e à castração. É certo que a linguagem só pode ser pensada no campo da relação. Se todo significante carece de significação, então, os significantes que contornam o bebê são fornecidos pelos significantes daqueles que o criaram, considerando o alinhamento (ou desalinhamento) entre discurso e desejo.

Constatamos que não há como aprisionar o sujeito do desejo, pois, como poeticamente expõe o bucólico Manoel de Barros (2001, p. 32) "quem anda no trilho é trem de ferro, sou água que corre entre pedras: liberdade caça jeito". Esse mesmo 
sujeito sempre encontra uma nova forma de se reinventar, se reencontrar, caçar seu próprio desejo em meio à obscuridade do inconsciente, visto a condição imparável da pulsão.

Da mesma forma, a psicanálise precisa se dedicar ao processo investigatório teórico e clínico para dar conta desse sujeito que chega a clínica com uma nova concepção subjetiva acerca de sua sexualidade e seu gênero. Assim como Lacan (1998, p. 321) infere que "deve renunciar à prática da psicanálise todo analista que não conseguir alcançar em seu horizonte a subjetividade de sua época". Freud (1898/2006, p. 254,264$)$ também discorre sobre as novas configurações da identidade da nossa era quando pontua que "há trabalho suficiente para se fazer nos próximos cem anos - nos quais nossa civilização terá de aprender a conviver com as reivindicações de nossa sexualidade". Portanto, acompanhar as demandas da nossa época é uma obrigação que o próprio lugar de analista nos impele através de formação e atualização contínua. Reinventar-se também é tirar-nos do lugar comum a que estamos habituados e circular pelo desconhecido, sempre inevitável, que se coloca na clínica.

\section{CONSIDERAÇÕES FINAIS}

Perceber que o ser humano e seus processos internos não possuem caráter estático foi o que levou a psicanálise a ser encarada como uma teoria revolucionária e libertadora, tanto para os conceitos tradicionalistas, como para ela mesma. Freud, na construção da teoria psicanalítica, considerou e reconsiderou vários de seus conceitos devido à maleabilidade observada na trama inconsciente que, apesar de seus processos e suas leis, mostra-se profundo.

Tem sido um desafio para os novos psicanalistas elaborar as compreensões das novas formas de subjetivação da sexualidade e do gênero em arcabouços teóricos que não caiam no tradicionalismo de desqualificar os novos arranjos. Quando os identificamos e os encaramos dentro de desvios tomando como parâmetro as configurações mais clássicas, estamos nos distanciando da compreensão totalitária que respeita a individualidade e a subjetividade do sujeito.

Consideramos que esse campo, vasto que é, ainda tem muito a ser estudado e vasculhado, e não podemos mais esperar para elaborar constructos teóricos, visto a 
urgente necessidade que a cultura tem tratado do tema e, em suma, à solta. Essas novas concepções se elaboram como qualquer outra, sendo também através dela, que se ancoram as noções de identidade, sexualidade e gênero.

É necessário considerar que o universo interno do sujeito não necessariamente precisa caber nos nossos livros, caso contrário, a psicanálise perderia o seu caráter metapsicológico que se propõe a avançar à medida que o sujeito saia de seus desarranjos. Assim sendo, a psicanálise é um saber aberto, passível de revisões sistemáticas baseada no que a experiência clínica tem a trazer de novidade.

O destravamento dos novos arranjos, que de novos não possuem nada, nos impelem a falar sobre o sujeito que, em suma, debate com o pensamento filosófico, cultural e social na linha de frente da representação do seu desejo. Esse sujeito que reafirma quem é e a que veio, causando mal-estar e, mesmo assim, sobrevivendo é o mesmo sujeito que busca referências, nomeações, dignidade, direitos.

\section{REFERÊNCIAS}

AMARAL, Mônica Guimarães Teixeira do. Os três ensaios sobre a teoria da sexualidade: um texto perdido em suas sucessivas edições? Psicol. USP, São Paulo, v. 6, n. 2, p. 63-84, $1995 . \quad$ Disponível em <http://pepsic.bvsalud.org/scielo.php?script=sci_arttext\&pid=S1678$51771995000200004 \&$ Ing=pt\&nrm=iso >. Acessos em 20 jan. 2020.

BARATTO, Geselda. A descoberta do inconsciente e o percurso histórico de sua elaboração. Psicol. Cienc. prof., Brasília, v. 29, n. 1, p. 74-87, mar. 2009. Disponível em <http://pepsic.bvsalud.org/scielo.php?script=sci_arttext\&pid=S141498932009000100007\&lng=pt\&nrm=iso>. Acessos em 19 jan. 2020.

BARROS, Manoel. Matéria de Poesia. Rio de Janeiro: Record, 2001.

CECCARELLI, Paulo Roberto. Psicanálise, sexo e gênero. Estud. psicanal., Belo Horizonte, n. 48, p. 135-145, dez. 2017. Disponível em $<$ http://pepsic.bvsalud.org/scielo.php?script=sci_arttext\&pid=S0100$34372017000200014 \&$ Ing=pt\&nrm=iso >. Acessos em 18 jan. 2020.

CHAUÍ, Marilena. Convite à filosofia. São Paulo: Ática, 2001.

COSSI, RAFAEL KALAF. PSICANÁLISE E BINARIDADE DE GÊNERO: UM DEBATE À LUZ DA SEXUAÇÃO LACANIANA. Ágora (Rio J.), Rio de Janeiro, v. 22, n. 3, p. 309-318, Dec. 2019. 
<http://www.scielo.br/scielo.php?script=sci_arttext\&pid=S1516-

$14982019000300309 \&$ Ing $=e n \& n r m=i s o>$.

on 22 Jan. 2020. Epub Sep 23, 2019. http://dx.doi.org/10.1590/180944142019003006.

FREUD, Sigmund. (1905). Um caso de histeria, Três ensaios sobre sexualidade e outros Trabalhos. Edição Standard Brasileira das Obras Psicológicas Completas de Sigmund Freud. Volume VII. Imago Editora. 2006. Rio de Janeiro.

. (1898). A sexualidade na etiologia das neuroses. In S. Freud. Edição standard brasileira das obras psicológicas completas de Sigmund Freud Vol. 3, pp. 249270. Rio de Janeiro: Imago.

HONDA, Helio. O conceito freudiano de pulsão (Trieb) e algumas de suas implicações epistemológicas. Fractal, Rev. Psicol., Rio de Janeiro, v. 23, n. 2, p. 405-422, Aug. 2011. Available from <http://www.scielo.br/scielo.php?script=sci_arttext\&pid=S1984$02922011000200012 \& \operatorname{lng}=e n \& n r m=i s o>$. Access on 18 jan. 2020. http://dx.doi.org/10.1590/S1984-02922011000200012.

JORGE, M. A. C. Sexo e discurso em Freud e Lacan. Rio de Janeiro: Jorge Zahar Editor, 1997

. Fundamentos da psicanálise de Freud a Lacan - v. 2: a clínica da fantasia. Rio de Janeiro: Zahar, 2010.

A teoria freudiana da sexualidade 100 anos depois (1905-2005). Psyche (Sao Paulo), São Paulo, v. 11, n. 20, p. 29-46, jun. 2007.. Disponível em $<$ http://pepsic.bvsalud.org/scielo.php?script=sci_arttext\&pid=S1415$11382007000100003 \&$ Ing=pt\&nrm=iso >. Acessos em 20 jan. 2020.

LACAN, J. Escritos. Rio de Janeiro: Jorge Zahar Editor, 1998.

. O Seminário, Livro 20: mais, ainda. 3. ed. Rio de Janeiro: Jorge Zahar, 2008.

(1958-59). O seminário, livro 6: O desejo e sua interpretação. Rio de Janeiro: Jorge Zahar Ed., 2016.

LIMA, Vinícius Moreira; BELO, Fábio Roberto Rodrigues. GÊNERO, SEXUALIDADE E O SEXUAL: O SUJEITO ENTRE BUTLER, FOUCAULT E LAPLANCHE. Psicol. Estud., Maringá, v. 24, e41962, 2019. Available from <http://www.scielo.br/scielo.php?script=sci_arttext\&pid=S1413-

73722019000100205\&lng=en\&nrm=iso>. access on 20 Jan. 2020.

MENDES, Eliana Rodrigues Pereira. PS - Pulsão e Sublimação: a trajetória do conceito, possibilidades e limites. Reverso, Belo Horizonte, v. 33, n. 62, p. 5567 , set. 
em<http://pepsic.bvsalud.org/scielo.php?script=sci_arttext\&pid=S0102-

$73952011000200007 \&$ Ing=pt\&nrm=iso >. Acessos em 19 jan. 2020.

SILVA, Alexsander Lima da; OLIVEIRA, Adélia Augusta Souto de. Transexualidade/travestilidade na literatura brasileira: sentidos e significados. Arq. Bras. Psicol., Rio de Janeiro, v. 65, n. 2, p. 274-287, 2013. Disponível em <http://pepsic.bvsalud.org/scielo.php?script=sci_arttext\&pid=S180952672013000200009\&Ing=pt\&nrm=iso>. Acesso em 21 jan. 2020.

SOUTO, Jailma Belarmino et al . As vias da transexualidade sob a luz da psicanálise. Cad. psicanal., Rio de Jeneiro, v. 38, n. 34, p. 187-206, jun. 2016 . Disponível em <http://pepsic.bvsalud.org/scielo.php?script=sci_arttext\&pid=S141362952016000100010\&lng=pt\&nrm=iso>. acessos em 20 jan. 2020.

STARNINO, Alexandre. Sobre identidade e identificação em Psicanálise: um estudo a partir do Seminário IX de Jaques Lacan. Dois Pontos, [S.I.], v. 13, n. 3, dez. 2016. ISSN <https://revistas.ufpr.br/doispontos/article/view/46901/30071>. Acesso em: 29 jan. 2020.

VIEIRA, Marcus Kleredis Monteiro. A construção do saber teórico-clínico freudiano. 0620 de jul de 2019. Notas de Aula.

WARMLING, D. L., Anlehnung: o rudimento do feminino em Freud. Kínesis, Marília, Vol. $\mathrm{XI}, \mathrm{n}^{\circ} 30$, dezembro2019, p.20-37. Disponível em <http://revistas.marilia.unesp.br/index.php/kinesis/article/view/9619>. Acesso em 20 jan. 2020. 


\title{
CAPÍTULO XVII
}

\section{DESIGUALDADE DE CLASSE, RAÇA E GÊNERO, E OS IMPACTOS DO COVID-19 NO BRASIL}

\author{
Girlian Silva de Sousa ${ }^{1}$ \\ Lilian Regina Furtado Braga ${ }^{2}$
}

${ }^{1}$ Doutoranda em Desenvolvimento Socioambiental. Programa de Pós-Graduação em Desenvolvimento Sustentável
do Trópico Úmido - UFPA. Bolsista CAPES.
${ }^{2}$ Mestranda em Sociologia e Direito. Programa de Pós-Graduação em Sociologia e Direito - UFF

RESUMO

Este trabalho, tem por objetivo, discutir sobre a desigualdade multidimensional de classe, raça e gênero no Brasil, a partir da abordagem da interseccionalidade. Para este fim, realizou-se uma pesquisa bibliográfica, sobre os dados produzidos até esse momento, sobre a evolução da pandemia do Coronavírus no Brasil, e seus custos sociais sobre as minorias. A partir de uma breve contextualização sobre a epistemologia interseccional, utilizou-se dessa abordagem para análise dos impactos da política de austeridade econômica sobre a desigualdade social no país, utilizando como foco principal, os impactos dessa política, sobre a população negra, em especial, sobre as mulheres negras. A partir dos dados levantados, conclui-se que a adoção do Estado Mínimo, promoveu retrocesso social e aumentou o abismo social entre ricos e pobres no país, além de intensificar a condição de vulnerabilidade social da população negra. Os resultados da pesquisa também apontam, que a população negra é a principal impactada pela pandemia, sendo que as mulheres negras, base da pirâmide social brasileira, estão arcando com os maiores custos socias da pandemia.

Palavras-chave: Mulheres negras. Racismo estrutural. Desigualdade social. Pandemia.

\section{INTRODUÇÃO}

Nos últimos meses, o mundo tem assistido estarrecido, aos impactos causados pelo Covid-19, enquanto se conjectura sobre seus alcances a médio e longo prazos. Até agora, a pandemia deixou um saldo negativo de 847. 400 mortes em todo mundo, e 25.300.289 casos confirmados até o dia 30 de agosto de 2020, segundo o Painel COVID19 do Centro de Ciência e Engenharia de Sistemas (CSSE) da Universidade Johns Hopkins. Destes, 120.828 mortes, e 3.862.311, foram computados no Brasil, que ocupa a vexatória posição de 2 o lugar no ranking de países mais afetados pela pandemia no mundo, perdendo apenas para os Estados Unidos, que contabiliza 183.258 mortes e 
6.009.899 casos confirmados de Covid-19 até a presente data (CSSE HONS HOPKINS UNIVERSITY, 2020).

O desempenho incipiente do Brasil no combate à pandemia, não chega a surpreender, dada à inaptidão do atual dirigente político do país, para o cargo, agravada pela tentativa insistente em copiar o desastroso modus operandi do atual governo estadunidense. A postura anticientífica, aliada ao despreparo e ao descaso em relação às questões sociais, foram decisivos para a atual situação do país. Contudo, a atual crise sanitária do país, não pode ser atribuída exclusivamente, ao Covid-19. O vírus foi o catalisador da situação de miséria e exclusão social, na qual o país foi mergulhado.

A expansão econômica protagonizada pela economia brasileira, entre 2004 a 2013, foi interrompida em 2015, com a doção da política de austeridade fiscal. Os avanços na área social, foram revestidos, e a desigualdade social voltou a crescer. Por se tratar de uma sociedade classista, racializada e sexista, a desigualdade atinge principalmente, a população as mulheres negras - base da pirâmide social. Desta forma, a o processo de opressão e exclusão social vivido por essas mulheres, aumentou exponencialmente, durante a pandemia da Covid-19, tornando-as, o grupo mais vulnerável aos impactos socias da pandemia.

Partindo dessa perspectiva, este trabalho tem por objetivo, discutir sobre a desigualdade multidimensional de classe, raça e gênero no Brasil, a partir da abordagem da interseccionalidade. Trata-se de uma pesquisa bibliográfica, a evolução da pandemia do Coronavírus no Brasil, e seus impactos sociais sobre a população negra, e de forma especial, sobre as mulheres negras. A partir de uma breve contextualização sobre a epistemologia interseccional, utilizou-se dessa abordagem para análise dos impactos da política de austeridade econômica sobre a desigualdade social no país, utilizando como foco principal, os impactos dessa política, sobre a população negra, em especial, sobre as mulheres negras. A partir dos dados levantados, conclui-se que a adoção do Estado Mínimo, promoveu retrocesso social e aumentou o abismo social entre ricos e pobres no país, além de intensificar a condição de vulnerabilidade social da população negra. 


\section{A ABORDAGEM INTERSECCIONAL DA DESIGUALDADE SOCIAL}

O processo de desigualdades experimentado pelas mulheres negras no Brasil e no mundo, tem provocado questionamentos sobre o lugar dessas mulheres, nas estruturas sexistas, colonialistas e racializadas da sociedade. Meninas, jovens, mães, filhas, trabalhadoras, as mulheres negras foram marcadas pelo processo de escravização, na dominação do proprietário dos escravizados e do feitor, no trabalho de sol a sol de igual forma ao trabalho dos homens negros, no empilhamento dos seus corpos em cabanas insalubres como suas moradias. Essa era sua perspectiva de sobrevivência, diferenciando-se em um violento detalhe do sofrimento irrogado aos homens, o estupro:

Como mulheres, as escravas eram inerentemente vulneráveis a todas as formas de coerção sexual. Enquanto as punições mais violentas impostas aos homens consistiam em açoitamentos e mutilações, as mulheres eram açoitadas, mutiladas e também estupradas. $O$ estupro, na verdade, era uma expressão ostensiva do domínio econômico do proprietário e do controle do feitor sobre as mulheres negras na condição de trabalhadoras (DAVIS, 2016, p.6).

O sistema escravista - caracterizado pela violência material e simbólica -, ainda influencia as relações sociais em nossa sociedade contemporânea, de modo que o lugar social das mulheres negras ainda é determinado sob a influência desse sistema. Assim, as questões de gênero, raça e classe são fundamentais na análise sobre a situação das mulheres negras no Brasil. Isto implica na adoção da abordagem epistemológica interseccional.

A emergência das discussões sobre interseccionalidade, surge nas discussões políticas feministas negras nos Estados Unidos pelos anos 1960 e 1970 . O trabalho de Toni Cade Bambara, "The Black Woman", nos anos 1970, é considerado inovador, indicando que a liberdade desejada pelas mulheres negras não avançaria sem os debates sobre raça, classe e gênero (COLLINGS, 2017). O manifesto "A Black Feminist Statement", do coletivo Combahee River, foi outra importante contribuição para o debate. Outro importante marco, é o artigo denominado "Mapping the Margins: Intersectionality, Identity Politics, and Violence against Women of Color", escrito por Kimberlé Crenshaw, e publicado na Stanford Law Review, em 1991. Trata-se de uma 
análise crítica sobre a situação social das mulheres negras, e que viria a ser reconhecido como os fundamentos teóricos da intereseccionalidade.

Um elenco de autoras que trazem à cena a discussão da interseccionalidade são citadas por Patrícia Hills Collings (2017, p.):

No trabalho de Jordan, assim como no de Angela Davis, Toni Cade Bambara, Shirley Chisholm, Alice Walker, Audre Lorde e outras feministas negras do período, pode-se encontrar uma declaração forte e precoce sobre interseccionalidade, em que a 'liberdade é indivisível', tanto intelectualmente quando nas múltiplas lutas políticas. Jordan argumentou que o feminismo negro exigia esforços contínuos para desmantelar a intersecção, as relações estruturais de poder de raça, classe, gênero e sexualidade, que reproduziram as injustiças sociais de uma geração à outra. Mas ela também viu que as mulheres afroamericanas jamais poderiam ser livres se perseguissem apenas o próprio interesse. A luta não tratava apenas de análises abstratas da liberdade, mas sobre as formas que as iniciativas de justiça social deveriam assumir para dar vida a políticas emancipatórias.

O termo é utilizado para marcar a existência de diversos elementos que perpassam e se entrecruzam nas relações sociais das mulheres negras e que determinam as suas condições de vida. Ainda que não haja uma hierarquia, as dimensões (classe, raça e gênero), devem ser analisados conjuntamente, em vista de não se perpetuar condições históricas opressão e desigualdade (DAVIS, 2016; CRENSHAW, 2002). Neste sentido, destaca-se a centralidade da justiça social no debate, posto que sem ela, quaisquer propósitos de emancipação, fracassariam. Angela Davis, destaca a insurgência da associação da questão de gênero ao sufrágio feminino.

O sufrágio feminino ampliou o leque de temas relacionados à opressão e à subalternização das mulheres: o direito à propriedade, à separação e o divórcio, estendendo-se às relações econômicas, na divisão sexual do trabalho. Infelizmente, estas discussões permanecem atuais, e ainda integram a pauta de reinvindicações das mulheres negras na atualidade. Isto porque, os mecanismos de opressão se modernizam, tornando a análise sobre a condição da mulher negra na sociedade, ainda mais complexa. Desta forma, embora permaneça um relativo silenciamento acadêmico em relação à epistemologia feminista negra, a interseccionalidade tem se mostrado sua profundamente relevante. Conforme destaca Crenshaw (2002), esta epistemologia é essencial para a compreensão sobre como as ações e políticas específicas, geram 
opressões que fluem ao longo de tais eixos, constituindo aspectos dinâmicos ou ativos do desempoderamento.

\section{RETRATO DA DESIGUALDADE MULTIDEMENSIONAL NO BRASIL:} RACISMO ESTRUTURAL, VIOLÊNCIA, MACHISMO, MISÉRIA, E ELITE ATRASADA

Segundo Max Weber, a desigualdade social é fruto do poder econômico, do prestígio social e do poder político. Enquanto a noção de poder está relacionada à capacidade de um indivíduo ou grupo "impor, numa ação social, a vontade própria, mesmo contra a oposição de outros participantes desta" (WEBER, 1999, p. 175). As classes sociais são expressões da distribuição do poder econômico. Isto significa que "o poder é a questão central de toda a sociedade. A razão é simples. É ela que nos irá dizer quem manda e quem obedece, quem fica com os privilégios e quem é abandonado e excluído" (SOUSA, 2017, p. 14).

No sistema capitalista, a classe dominante utiliza o poder econômico, para a aquisição dos demais poderes (político, intelectual, jurídico, religioso, midiático, entre outros). Para Karl Marx (1998), desigualdades sociais são inerentes ao sistema capitalista, visto que as relações de produção nesse sistema, pressupõem a expropriação do trabalhador dos meios de produção, enquanto o aliena dos resultados do próprio trabalho. Desta forma, o capital (como relação social), cria de forma simultânea, riquezas e desigualdades sociais.

Em contraponto à concepção da luta de classes, Thomas Piketty, autor do livro "Capital e ideologia", postula a premissa da mutação nas disputas ideológicas; segundo o autor, o maior mal estrutural do planeta (a desigualdade), é uma opção política de Estado. A desigualdade dá forma à ideologia - cuja função é legitimá-la. Através dos discursos ideológicos, os grupos dominantes validam a apropriação desigual, da riqueza socialmente produzida. Para isto, utilizam-se dos poderes jurídicos, midiáticos, políticos, e seus mecanismos institucionais, para criar, controlar leis e atuar através do poder de polícia do Estado. Enquanto isso, o vicioso discurso da "meritocracia", cria uma aparência de justificação (PIKETTY, 2020). 
Dizer que "o dinheiro irá para os negros", é o argumento ideológico mais utilizado para combater a políticas de redução do abismo social, em sociedades racistas como as do Brasil, África do Sul e Estados Unidos (PIKETTY, Thomas. É hora de distribuir melhor a riqueza, diz Piketty em novo livro. [entrevista concedida ao Financial Times], publicada no Valor Econômico, 2019). Pressupostos teóricos à parte, na prática, o termo "sociedade desigual", é sinônimo de iniquidade nas oportunidades de viver com cidadania. No Brasil, de modo especial, "oportunidades" equivalem ao acesso à alimentação, educação, saúde e habitação, principalmente. Elas determinarão a probabilidade de o indivíduo viver fora do sistema carcerário, ascender socialmente, ou às chances de chegar à idade adulta. Esta percepção é fundamental para a análise multidimensional da desigualdade.

No Brasil, o racismo estrutural está no cerne da desigualdade multidimensional. O custo desproporcional do Coronavírus, para as populações negra e indígena no Brasil, é reflexo de um processo histórico e interseccional, que abrange disputas políticoideológicas relacionadas às questões de classe, raça e gênero; O Covid-19 foi o catalisador que pôs a descoberto, a dimensão do abismo social no país. Trata-se de uma sociedade elitista, racista, machista, patriarcal, heteronormativa, e sem consciência de classe. Os resquícios da lógica social herdada do sistema escravista colonial, estimula a manutenção dos mecanismos de opressão e subalternização da população negra e indígena. O esforço para a eliminação dessas chamadas "minorias sociais" é histórico. Neste sentido, o próprio termo "minorias", está carregado de signos sociais.

Genocídio e encarceramento em massa, assassinatos sem punições, são instrumentos de repressão às tentativas de mudança do status quo - vide o caso Marielle Franco e de outras lideranças dos movimentos sociais -, despertando (quando muito), reações fugazes e superficiais na sociedade. Atualmente, "notas de repúdio", parecem ter se tornado a "máxima eloquência" da indignação. Isto diz muito sobre uma sociedade, que prefere ignorar os seus próprios George Floyd: o caso da comerciante negra de 51 anos de idade, que teve o pescoço pisado por um policial militar em São Paulo, enquanto se encontrava caída no chão, já rendida, não provocou espanto ou grande comoção, assim como parece naturalizada pela sociedade, a taxa de homicídio de $98,5 \%$ para pessoas perdas e pardas, em relação aos $34 \%$ para pessoas brancas, para cada 100 mil habitantes em 2017 (IBGE, 2019). 
Em se tratando da violência policial, os alvos preferenciais são jovens negros pretos e pobres; somente no Rio de Janeiro, dos 1.814 mortos em ações da polícia, 1.423 eram pretos ou pardos. Isto significa que $78 \%$ das vítimas, eram pessoas negras. $43 \%$ delas, estavam na faixa etária entre 14 e 30 anos de idade. Os dados foram levantados pelo Instituto de Segurança Pública do Rio de Janeiro (ISP-RJ), e obtidos pelo G1, através da Lei de Acesso à Informação (RODRIGUES; COELHO, 2020).

É imperativo lembrar as crianças vítimas da violência do racismo estrutural no poder de polícia no Rio de Janeiro; somente em 2019, foram 16 crianças baleadas, e cinco mortas: Jenifer Silene Gomes, 11 anos, morta no dia 14 de fevereiro, durante ação da polícia militar, no bairro Triagem, na Zona Norte; Kauan Peixoto, 12 anos de idade, morto no dia 17/03/2019 vítima de bala perdida, durante ação policial, na comunidade da Chatuba, em Mesquita, na Baixada Fluminense; Kauã Rozário, 11 anos de idade, morto após atingido por bala perdida, durante ação da polícia, no dia 10 de maio de 2019, na Vila Aliança, em Bangu; Kauê Ribeiro dos Santos, 12 anos de idade. Trabalhava vendia balas. Foi morto quando voltava para casa, durante operação da polícia militar no dia 08 de setembro de 2019, na Chapadão, na Zona Norte; Àgatha Félix, morta aos 8 anos de idade durante operação policial no Complexo do Alemão, no dia 20 setembro de 2019 (BARRERA; TORRES, 2019; PEIXOTO, 2019; G1 RIOa, 2019a; G1 RIOb, 2019; NASCIMENTO, 2019; GLOBONEWS, 2019).

Em "A elite do atraso: da escravidão ao Lava Jato", Jessé Souza destaca o papel das elites na manutenção da opressão por raça e classe no país:

Outro fator que perdura até nossos dias é que o medo dos escravistas da "rebelião negra" se transforma e é substituído pela definição do negro como "inimigo da ordem". Sendo a "ordem" percebida já no seu sentido moderno de significar decoro, respeito à propriedade e segurança. Vem daí, portanto, o uso sistemático da polícia como forma de intimidação, repressão e humilhação dos setores mais pobres da população. Matar preto e pobre não é crime já desde essa época. As atuais políticas públicas informais de matar pobres e pretos indiscriminadamente efetuadas por todas as polícias do Brasil, por conta do aval implícito ou explícito das classes médias e altas, têm aqui seu começo. As chacinas comemoradas por amplos setores sociais de modo explícito, em presídios de pretos e brancos pobres e em chance de se defender, comprovam a continuidade desse tipo de preconceito covarde (SOUZA, 2017, p. 48).

Esta reflexão aduz à atual conjuntura econômica e sociopolítica, pós-golpe sexista e antidemocrático de 2016; o racismo estrutural, o machismo e o ódio de classe, 
são cernes das políticas de austeridade fiscal, das medidas de precarização do trabalho, do retrocesso nos direitos sociais adquiridos e, principalmente, da eleição do governo bolsonarista. A pandemia agravou esse cenário, mergulhando o país em uma gigantesca crise: econômica, política, sanitária e social. Como resultado, consolidou-se o processo de formação do que Jessé Souza, já em 2017, chamou de "ralé de novos escravos".

Esta "ralé" é formada majoritariamente, pela população negra - principalmente as mulheres negras -, base da pirâmide social, força de trabalho subalternizada, mal remunerada e exposta aos maiores riscos de contaminação pelo Covid-19. Esta parcela da população, sofreu o duplo ataque das políticas de austeridade fiscal, que no contexto de pandemia intensificou a situação de miséria, abandono e exploração.

\subsection{Austeridade fiscal e agravamento do abismo social}

Após uma década de avanços (ainda que tímidos), na política distributiva e redução da miséria. A partir de 2015, essa tendência foi abruptamente interrompida, passando a apresentar retrocesso econômico, influenciando negativamente nos índices de desigualdade social da América Latina. Como um país que vinha logrando uma década de trajetória econômica ascendente, mergulhou em terrível recessão econômica, a partir de 2016?

Eis o que penso que aconteceu: o Brasil parece ter sido atingido por uma tempestade perfeita de má sorte e más políticas, com três aspectos principais. Primeiro, o ambiente mundial deteriorou-se de maneira acentuada, com a queda dos preços das exportações de commodities, ainda muito importante para a economia brasileira. Em segundo lugar, os gastos privados domésticos também caíram, talvez por causa de um acúmulo excessivo de dívidas. Em terceiro lugar, a política, em vez de combater a depressão, exacerbou-a, com austeridade fiscal e aperto monetário, mesmo quando a economia já estava em queda franca (KRUGMAN, Paul. Que diabos aconteceu com o Brasil? [artigo publicado por The New York Times, 12-11-2018]. Tradução de André Langer, publicado em Instituto Humanitas Usininos, em 15-11-2018.

Ao referir-se a atual recessão brasileira, Paul Krugman, Prêmio Nobel de Economia em 2008, descreve como a política de austeridade econômica mergulhou o país em uma espiral de crise econômica. Isto porque, a despeito da propaganda neoliberal sobre os supostos benefícios da política de "Estado Mínimo", na prática, esta política tem se mostrado pouco eficaz e até mesmo danosa, no enfrentamento das crises econômicas, por adotar medidas que promovem concentração de renda e riqueza, 
"atuando de forma seletiva e sexista, transformando os efeitos negativos para a saúde dos indivíduos e colabora para a degradação do meio ambiente (DWECH; OLIVEIRA; ROSSI, 2008, p.7). Não seria novidade, portanto, que as mulheres negras sofreriam os maiores impactos do desmonte das políticas públicas voltadas para a redução da pobreza e regularização do mercado de trabalho.

De 2004 a 2013, o Brasil implementou políticas macroeconômicas de promoção do crescimento econômico, com inclusão social. Como resultado, verificou-se o crescimento do emprego formal e o aumento do poder de compra dos respectivos salários (BALTAR; SOUEN; CAMPOS, 2018). Os efeitos sobre o emprego formal foram resultado das políticas direcionadas à promoção da regulamentação da atividade econômica e trabalhistas. Houve um aumento do rigor da fiscalização realizada pela Receita Federal, na época, contribuindo para o sucesso na formalização dos contratos de trabalho e para os significativos superávits fiscais obtidos pelo Estado durante o período (BALTAR; SOUEN; CAMPOS, 2018).

A aprovação da Emenda Constitucional 95 (EC 95), que prevê o congelamento dos gastos públicos pelos próximos vinte anos, comprova a afirmação de Thomas Piketty, de que "A desigualdade não é econômica ou tecnológica: ela é ideológica e política" (PIKETTY, Thomas. [entrevista concedida ao Financial Times], publicada no Youtube, 2019). A EC 95, é projeto de retrocesso social, justificado por discursos ideológicos sobre a suposta incapacidade de o orçamento do Estado brasileiro arcar com o pacto social da Constituição Cidadã de 1988. "Com base nesse discurso foi aprovada a EC 95 que, para muito além de uma medida de ajuste fiscal, é um projeto de desconstrução do pacto social de 1988 naquilo que ele tem de melhor: a cidadania social". Esta medida, foi agravada pela reforma trabalhista, que representou um retrocesso nos direitos adquiridos pelos trabalhadores brasileiros (DWECH; OLIVEIRA; ROSSI, 2008, p.7).

Dwech; Oliveira e Rossi (2018) destacam, que a austeridade econômica é uma política machista, uma vez que as desigualdades na divisão sexual do trabalho no Brasil, tendem a inserir as mulheres em relações de trabalho precarizadas. Ademais, na sociedade brasileira, as atividades domésticas são desempenhadas predominantemente, por mulheres; por conseguinte, para as trabalhadoras de baixa renda, isto significa duplas de trabalho, uma vez que permanecem como as principais 
encarregadas pelo cuidado dos filhos. Além disso, nos últimos anos, o número de famílias chefiadas por mulheres aumentou consideravelmente. Segundo a consultoria IDados, quase a metade das famílias brasileiras, já são chefiadas por mulheres: em 2019, $47,5 \%$ dos lares eram chefiados por mulheres. Desses, 55,5\% eram chefiados por mulheres negras (DESOTI, 2020).

Vale destacar, que em 2018, dois anos antes da pandemia, os efeitos dos cortes de gastos nas políticas sociais para a redução das desigualdades de raça e gênero no Brasil, mostravam estatísticas preocupantes: entre 2014 e 2017, as mulheres eram maioria entre os desempregados. Enquanto a taxa de desemprego entre as mulheres brancas havia crescido $73 \%$, entre as mulheres negras o desemprego havia praticamente duplicado (96\%). A ocupação em empregos informais era maior entre as mulheres do que entre os homens. Não obstante os resultados, o orçamento destinado ao combate à violência contra a mulher, sofreu corte de 83\%, em 2018 (DWECH; OLIVEIRA; ROSSI, 2008).

A partir de 2015, o Estado brasileiro optou abandonas as políticas de promoção da equidade social e racial. Como resultado dos cortes nos gastos sociais, no ano de 2017, verificou-se o aprofundamento do retrocesso social: i) o aumento da mortalidade infantil, que durante 26 anos, tinha trajetória descendente; ii) a estratégia de inclusão social através da educação, foi desde então esquecida; iii) o acesso à cultura deixou de ser considerado instrumento de promoção de cidadania; iv) aumento alarmante da violência contra jovens e negros; v) menosprezo pelo agricultura familiar, da questão agrária, e abandono da questão da segurança alimentar e do combate à fome; vi) desprezo e tentativa de desqualificação da luta antirracista (DWECH; OLIVEIRA; ROSSI, 2018). Como agravante, a partir de 2019, a desvalorização dos direitos humanos, assumida abertamente, como posicionamento político do governo.

4. IMPACTOS DO CORONAVÍRUS SOBRE A POPULAÇÃO NEGRA: O ROSTO FEMININO DA PANDEMIA DA COVID-19

O título acima, foi inspirado no artigo publicado pela Organização das Nações Unidas no Brasil, ainda no mês de abril deste ano, praticamente no início da pandemia. O artigo declarava que "A pandemia da COVID-19 tem um rosto feminino". Trazia como 
destaque, a foto de Asha Rose Sillah, liderança feminina negra, refugiada do Sudão do Sul, que vive em Uganda. O texto explicava como as mulheres, em especial, as mulheres negras, devido às desigualdades de classe, cor e gênero se tornaram as pessoas mais vulneráveis á Covid-19 e aos custos sociais gerados pela pandemia (ONU BRASIL, 2020; PINHEIRO; TOKARSKI; VASCONCELOS, 2020).

Em sociedades patriarcais, racializadas e classistas, as mulheres representam o grupo social mais vulnerável. Assim, a divisão sexual tradicional do trabalho, é dos determinantes da desigualdade de oportunidades para as mulheres. A pandemia da Covid-19 evidenciou essa situação, ao denunciar o grau de exclusão e vulnerabilidade das trabalhadoras domésticas. Desta forma, nesta sessão, destacaremos os custos sociais da pandemia do Coronavírus, a partir do enfoque dos impactos da Covid-19, sobre as mulheres negras, em especial, sobre as trabalhadoras domésticas.

Na América Latina e Caribe, o trabalho doméstico se destaca entre as atividades laborais mais subalternizadas, devido às relações de trabalho precarizadas. A subalternização do trabalho doméstico é um legado do sistema escravista colonial. Mesmo após a abolição formal, às mulheres negras foi relegado o papel de doméstica, onde a força de trabalho - e muitas vezes, os corpos - dessas mulheres, permaneceram desqualificados e explorados, como referência à suposta supremacia branca. Ainda hoje, esta atividade é exercida majoritariamente pelas mulheres das minorias sociais.

Na América Latina e Caribe, entre 11 e 18 milhões de pessoas estão trabalham. 93\% são mulheres. Aproximadamente, $63 \%$ das pessoas que trabalham no serviço doméstico, são afrodescendentes; 77,5\% delas, em condições de informalidade. Os rendimentos médios das trabalhadoras domesticas são iguais ou inferiores ao $50 \%$ da média de todas as pessoas ocupadas, mesmo quando recebem um salário mínimo (SALVADOR; COSSANI, 2020). Trata-se de uma atividade classista, racista, e sexistas e pouco regulada. Esta condição, torna a atividade mal remunerada, enquanto a ausência/insuficiência de proteção social, expõe essas trabalhadoras a vários tipos de abusos, violência e discriminação. Salvador e Cossani (2020, p. 3), destacam:

Historicamente, o trabalho doméstico sintetiza a junção das discriminações baseadas em raça/etnia (servidão) e das de gênero (atribuição das tarefas domésticas e de cuidado de forma quase exclusiva às mulheres), já que muitas das pessoas vinculadas ao setor do serviço doméstico na região foram principalmente mulheres indígenas e afrodescendentes, o que faz aprofundar a discriminação. 
Tudo isso dificultou a transformação da visão de exploração histórica e do posicionamento do princípio de que o Estado e o/a empregador/a devem garantir os direitos trabalhistas do trabalho doméstico com os mesmos direitos trabalhistas dispensados a outros trabalhos, assegurando o trabalho decente.

A pandemia da Covid-19 agravou o nível de vulnerabilidade das trabalhadoras domésticas. O grau de insalubridade da atividade, também aumentou durante a pandemia. Destacam-se os seguintes fatores explicativos: i) o aumento da demanda por cuidado e monitoramento às populações de risco (pessoas idosas e/ou pessoas doentes); ii) necessidade de deslocamento através transporte público; iii) exposição ao vírus, durante a realização das compras para abastecimento dos domicílios onde trabalham, sem os devidos itens de proteção; iv) risco de contaminação, pelo uso muitas vezes excessivo e incorreto dos produtos de limpeza, nos lares onde trabalham; v) aumento da coação para o pernoite nos locais de trabalho. Isto provocou o afastamento de suas famílias, e a sobrecarga de trabalho. Estes fatores aumentaram o nível de exposição ao vírus e o risco de contaminação dessas mulheres, e de suas famílias (SOF, 2020; SALVADOR; COSSANI, 2020; PINHEIRO; TOKARSKI; VASCONCELOS, 2020).

Segundo o relatório "Sem parar: o trabalho e a vida das mulheres na pandemia", realizado pela organização feminista Sempre Viva, 52\% das mulheres brasileiras, realizaram atividades de cuidado de outras pessoas, durante a pandemia. $52 \%$ das mulheres negras entrevistadas, passaram a ser responsabilizar pelos cuidados de alguém. 58\% das entrevistadas que haviam perdido o emprego, eram negras (SOF, 2020). De acordo com a ONU Mulheres Brasil, a atividade doméstica concentra a maior quantidade de profissionais femininas no Brasil: dos 6 milhões de profissionais do setor, $90 \%$ são mulheres, sendo $60 \%$ mulheres negras. Menos de $40 \%$ delas, possuem carteira assinada (ONU MULHERES BRASIL, 2020). Não sem motivo, a primeira mulher vítima fatal da Covid-19 no país, foi uma trabalhadora doméstica:

No caso da contratação de trabalho doméstico, são mulheres, em geral, negras e pobres, com baixa escolaridade, que assumem o trabalho doméstico de famílias mais abastadas, possibilitando que os homens sigam se desresponsabilizando por este trabalho e que outras mulheres, em geral brancas e com maiores recursos, possam "resolver" sua sobrecarga de trabalho doméstico, tanto para a entrada no mercado de trabalho quanto para outros fins, entre os quais apaziguar eventuais tensões e conflitos causados por um estremecimento da divisão sexual tradicional do trabalho. A terceirização do trabalho doméstico cria, portanto, uma oposição de classe e raça entre as próprias mulheres, ao 
mesmo tempo que se configura em uma solução privada para um problema público, sendo, portanto, acessível apenas àquelas famílias com mais renda (PINHEIRO; TOKARSKI; VASCONCELOS, 2020).

Um importante indicador da interseccionalidade na questão da desigualdade social no Brasil, é a ausência ou insuficiência dos dados sobre o impacto da pandemia da Covid-19 por raça e gênero no país. O racismo estrutural e o sexismo, dificultam o diagnóstico do problema, e a proposição de soluções. A ausência dessas informações reforça a afirmação de Thomas Piketty, de que a desigualdade social é uma escolha política e ideológica: não se pode tratar de um problema, cuja existência ignoramos ou pouco conhecemos. Por conseguinte, as barreiras institucionais, tornam os avanços nas análises sobre os impactos da pandemia sobre as mulheres negras, ainda incipientes, a despeito do esforço intelectual dos pesquisadores que se dedicam a pesquisar o problema.

\subsection{A desigualdade multidimensional no contexto da Covid-19 no Brasil}

A desigualdade social provoca diferenciação nos impactos da pandemia da Covid-19. Esta diferenciação está relacionada à classe, raça e gênero da população. Isto se explica pelo acesso desigual ao mecanismos de prevenção e tratamento. O grande abismo social entre ricos e pobres, em termos de renda no Brasil, fazem com que o maior fardo social da pandemia, recaia sobre a população pobre, negra, feminina e moradora das periferias e favelas do país. Além do grau de exposição dessa população ao vírus, a distribuição espacial dos recursos relacionados à saúde de maneira geral, é fundamental para determinar quem terá ou não acesso à hospitais e equipamentos de emergência. Partindo dessa premissa, apresentaremos a seguir, os resultados de duas pesquisas, independentes, cujos resultados, parecem lançar luz sobre os impactos da pandemia no país.

O Núcleo de Operações e Inteligência em Saúde (NOIS), liderado pelo Departamento de Engenharia Industrial do Centro Técnico Científico da PUC-Rio (CTC/PUC-Rio), pesquisou a variação da taxa de letalidade da COVID-19 no Brasil (número total de óbitos dividido pelo total de casos encerrados), conforme as variáveis demográficas e socioeconômicas da população. Os índice considerados foram: idade; município do caso registrado; raça/cor; escolaridade; tipo de internação (enfermaria ou Unidade Terapia Intensiva - UTI), e o Índice de Desenvolvimento Humano Municipal 
(IDHM), utilizando valores obtidos pelo Atlas do Desenvolvimento Humano no Brasil (2010) para 5.565 municípios de ocorrência dos casos da COVID-19. A partir de dados atualizados até 18 de maio de 2020, os pesquisadores avaliaram aproximadamente, 30 mil casos encerrados das notificações de Síndrome Respiratória Aguda Grave (SRAG) confirmadas para Covid-19, disponibilizadas pelo Ministério da Saúde, e que correspondiam apenas aos casos graves (NOIS, 2020).

Os resultados apurados pela pesquisa constataram desigualdades no acesso ao tratamento da Covid-19: as chances de morte para paciente preto ou pardo analfabeto, era de $76 \%$. Para um paciente branco com nível superior de escolaridade, era de $19,6 \%$. Ou seja, o risco de morte para um paciente preto ou pardo com Covid-19, era 3,8 vezes maiores do que para um paciente branco com nível superior de escolaridade. Desigualdades econômicas regionais foi apontado como um dos fatores determinantes das diferenças nas taxas de óbitos entre classes sociais, no enfrentamento da doença no Brasil. A pesquisa "Multidimensional Inequality and Covid-19 In Brazil”, publicada pelo Levy Economics Institute of Bard College, neste mês de setembro, encontrou resultado semelhante, no que diz respeito à relação das desigualdades regionais e o tratamento da doença.

As regiões Norte e Nordeste, apresentam os maiores índices de desigualdade social, e também acumulam altas taxas de contaminação e mortes por 100.000 mortes no país (NOIS, 2020; NASSIF-PIRES; CARVALHO; RAWET, 2020). Quanto às taxas de óbitos por Covid-19, por raça no Brasil, até o dia 18 de maio de 2020, a taxa de óbitos foi de $54,78 \%$ para pessoas negras e pardas, e 37,93 , para pessoas brancas, conforme demonstrado na Figura 1. 
Figura 1 - Percentual de óbitos ou recuperados por Raça/Cor

Raça/cor

Branca

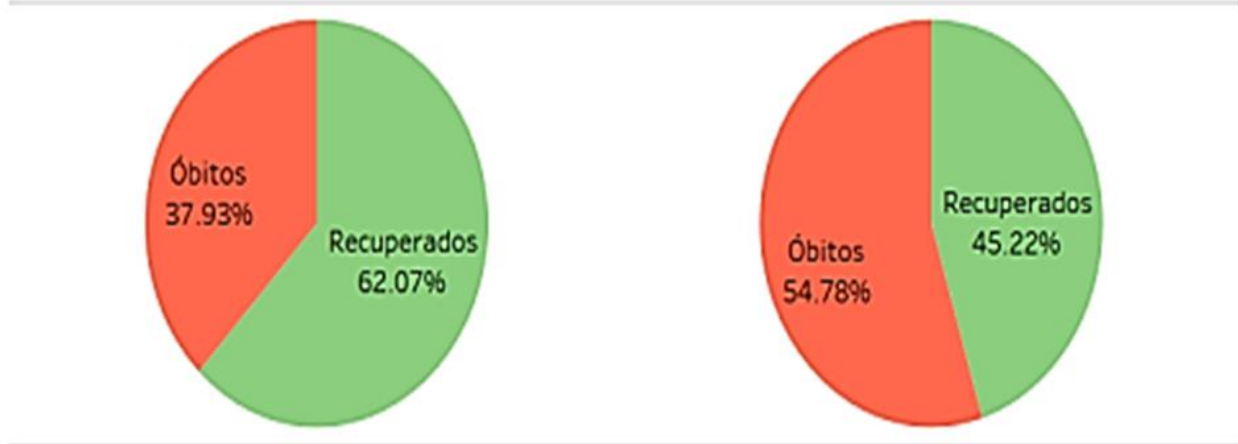

Preta \& Parda

Fonte: Núcleo de Operações e Inteligência em Saúde (NOIS), 27/05/2020.

Os resultados indicam influência do racismo estrutural na determinação de quem morrem ou recupera da doença no Brasil, mesmo quando o paciente consegue acesso às unidades de tratamento intensivo, conforme demonstrado na Figura 3. Segundo Quando o quesito "nível de escolaridade", é adicionado à análise, os resultados indicam existência de correlação entre o nível de escolaridade e as chances de recuperação. As chances de óbitos por Covid-19, para pacientes sem escolaridade, era de $71,3 \%$, enquanto para os pacientes com nível superior era de $22,5 \%$. Ou seja, as chances de óbito entre os pacientes sem nível de escolaridade, era três vezes maiores do que para os pacientes com nível superior (NOIS, 2020). 
Figura 2 - Proporção de óbitos e recuperados para pacientes internados em enfermaria

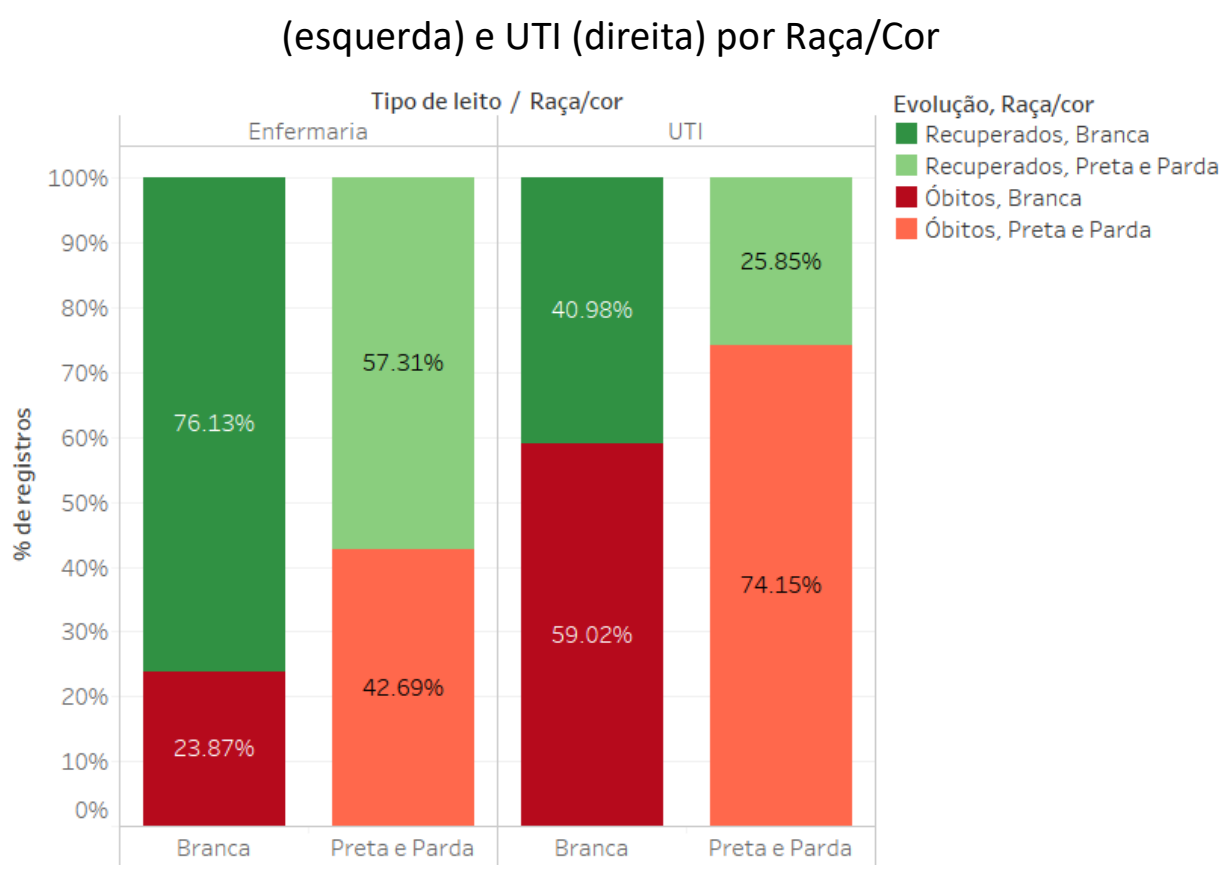

Fonte: Núcleo de Operações e Inteligência em Saúde (NOIS), 27/05/2020.

A desigualdade racial no acesso ao ensino superior, não demonstrou ser o principal fator determinante das disparidades nas taxas de óbitos, conforme demonstra a Figura 3. Pessoas pretas e pardas, tiveram as maiores taxas de óbitos em todos os níveis de escolaridade. Pretos e pardos sem escolaridade tiveram taxa de óbito de $80,35 \%$, enquanto brancos sem escolaridade, tiveram taxa de $19,65 \%$. Ou seja, a proporção de óbitos para pretos e pardos sem escolaridade, é quatro vezes superior a dos brancos sem escolaridade. Quando comparados na mesma faixa de escolaridade, em média, a taxa de óbitos para pretos e pardos é $37 \%$ maior do que para brancos. Destaca-se que os resultados apurados por Nassif; Carvalho-Pires e Rawet (2020), indicam a discriminação por raça, supera a discriminação por classe social, visto que o índice de vulnerabilidade ao Covid-19, para uma pessoa negra com níveis de renda mais elevados, permanece alto, em relação à de uma pessoa branca. Isto demonstra o grau de racismo e marginalização, da sociedade brasileira. 
Figura 3 - Proporção de óbitos ou recuperados por escolaridade e Raça/Cor

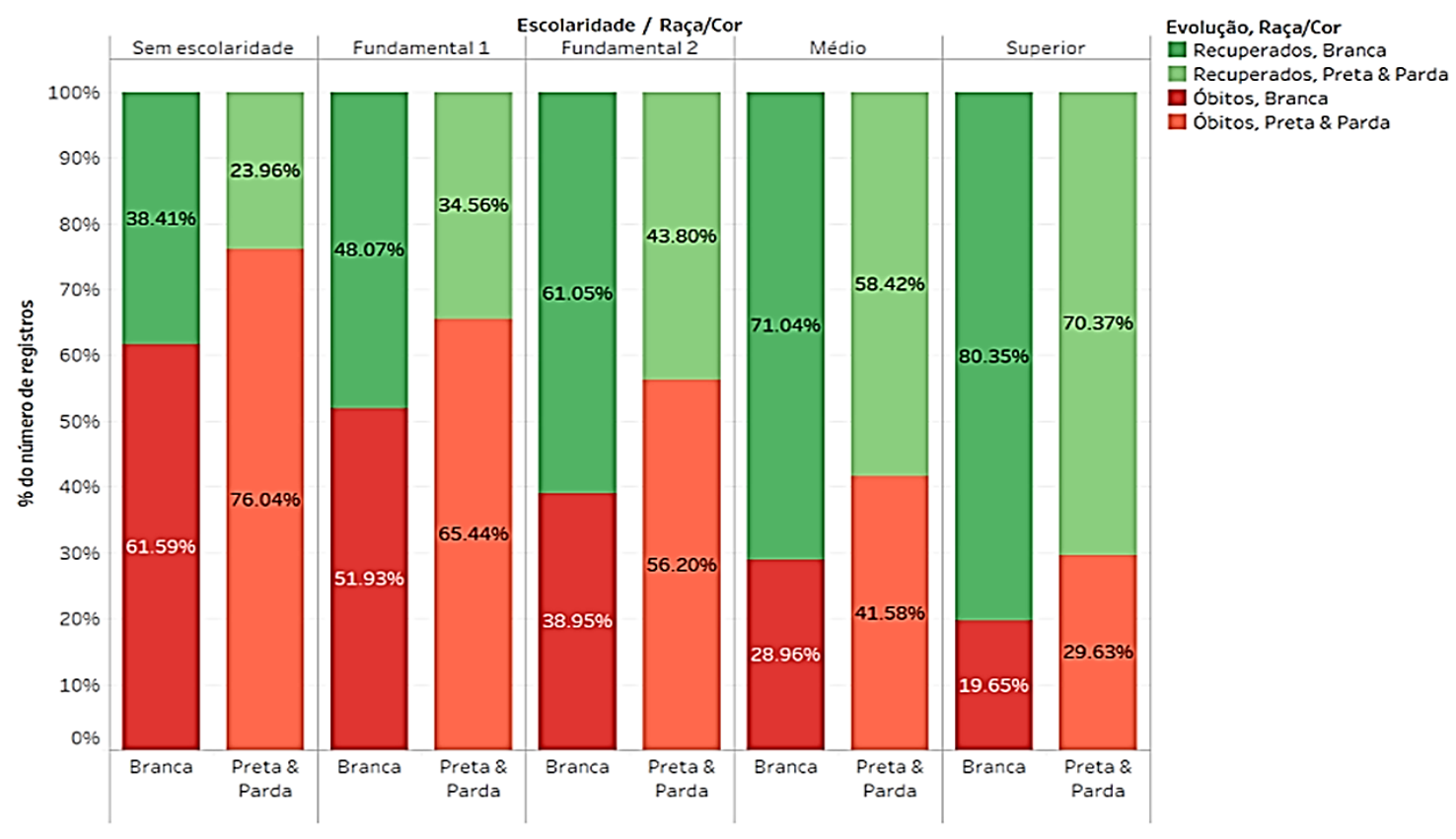

Fonte: Núcleo de Operações e Inteligência em Saúde (NOIS), 27/05/2020.

Combinados todos os dados disponíveis sobre os casos de Covid-19, que tiveram acesso ao atendimento médico, os resultados demonstraram o grau de racialização da sociedade brasileira. Os pacientes brancos e sem escolaridade, apresentaram taxa de óbitos de $48 \%$ na enfermaria, e $71 \%$ na UTI. Pacientes pretos e pardos, com a mesma escolaridade, tiveram proporção de óbitos de $69 \%$ na enfermaria, e $87 \%$ na UTI. A desigualdade entre pessoas com ensino superior é ainda mais grave; a proporção de óbitos de pessoas pretas e pardas e maior que o dobro da proporção de óbitos de pessoas brancas na enfermaria: $17 \%$ e $7 \%$, respectivamente. Para os óbitos na UTI, a diferença é aproximadamente, 60\%. Proporção de óbitos de pretos e pardos com nível superior na UTI, era de $63 \%$, contra $40 \%$ de óbitos de brancos com nível superior na UTI (NOIS, 2020). Estes resultados, confirmam as análises anteriores sobre a influência do racismo estrutural da distribuição dos custos socias da pandemia da Covid-19 no Brasil. 


\section{CONSIDERAÇÕES FINAIS}

Embora a pandemia da Covid-19, tenha impactado profundamente na qualidade de vida das mulheres da América Latina e o Caribe, os custos sociais são ainda maiores, para as mulheres negras, indígenas e imigrantes, na região. As mulheres são o grupo mais vulnerável aos impactos do Coronavírus. Esta situação, decorre do classismo, e do sexismo das sociedades racializadas da região. Entre as mulheres, as principais vítimas da pandemia na América Latina e o Caribe, são as empregadas domésticas, em decorrência das desigualdades geradas pelas relações socias na divisão sexual tradicional do trabalho. Nesse contexto, o trabalho doméstico, representa a atividade laboral, que melhor representa a apropriação desigual de recursos na região.

No Brasil, a adoção de políticas de austeridades fiscais a partir do ano de 2015, mergulhou o país em uma grave recessão econômica, com profundos impactos sociais. A aprovação da EC 95, prevê o congelamento dos gastos públicos pelos próximos vinte anos. Isto significa cortes no orçamento destinado às áreas fundamentais à promoção do crescimento econômico e bem estar social: saúde, educação, habitação e combate à violência contra as minorias. Ao contrário do período virtuoso da economia, quando Estado promoveu crescimento econômico com inclusão social, o país vive uma conjuntura de recessão econômica com exclusão social. As políticas do atual governo, demonstra claramente, o rompimento com a proposta dos governos anteriores, em reduzir as desigualdades.

Este cenário foi agravado pela pandemia da Covid-19, que revelou e aprofundou a desigualdade multidimensional no país. A adoção de uma epistemologia interseccional, é fundamental para análise de um cenário tão complexo, quanto o da pandemia no Brasil. A insuficiência de informações sobre as vítimas da Covid-19, dificultam o diagnóstico sobre a extensão dos custos socias da pandemia. No entanto, o esforço de alguns pesquisadores, e dos movimentos sociais, tem produzido pesquisas que revelam importantes informações, não somente sobre a conjuntura econômica e sociopolítica como um todo, mas, principalmente, sobre a lógica de funcionamento da sociedade brasileira, revelando que os avanços na construção de uma sociedade mais igualitária, ainda são bastante incipientes. 
No que diz respeito à divisão sexual tradicional do trabalho, as mulheres negras ainda são maioria, na execução de atividades subalternizadas e insalubres. O trabalho doméstico, permanece como uma atividade pouco regulada, mal remunerada e precarizada; por esse motivo, destinada às mulheres negras, como expressão do lugar social destinado às essas mulheres, pelo sistema de exclusão social e exploração, da sociedade brasileira. Nesse sentido, a interseccionalidade é uma ferramenta fundamental, para a análise das diversas dimensões da opressão, sofrida pelas mulheres negras.

As pesquisas revelam o grau de insalubridade social no Brasil. A sociedade brasileira permanece classista, machista, sexista e racializada. A partir das informações apresentadas neste trabalho, conclui-se que o racismo no Brasil é problema extremamente letal: o racismo estrutural, atribui raça, sexo e classe social à pandemia da Covid-19. Embora a ausência de dados sobre o gênero das vítimas, impossibilite um olhar mais apurado sobre a questão, os resultados obtidos até agora, já permitem afirmar que ser uma pessoa negra e pobre, aumenta consideravelmente, as chances de óbitos dos pacientes. Outro dado de profunda relevância, são as taxas de óbito por escolaridade. Os dados apontam a possibilidade de que para uma pessoa negra, a posse do nível superior de escolaridade, e/ou melhor nível de renda, não significa, necessariamente, melhores condições de acesso ao serviço de saúde, maior probabilidade de não ser vitimado pelo racismo, e consequentemente, melhores chances de preservação da vida.

Neste sentido, as abordagens multidemsional da desigualdade social, através da interseccionalidade, representam uma importante contribuição epistêmica, para os estudos sobre o lugar social da população negra, em especial, as mulheres, como forma de contribuir para o debate sobre a importância do combate ao racismo estrutural e à desigualdade de gênero, como condição para a construção de uma sociedade mais progressista e igualitária.

\section{REFERÊNCIAS}

BARREIRA, Gabriel; TORRES, Lívia. Famílias das 5 crianças mortas por bala perdida no RJ em 2019 cobram respostas e contestam polícia: 'Virou rotina'. G1 Rio e TV Globo, 2019. em: $<$ https://g1.globo.com/ri/rio-de- 
janeiro/noticia/2019/09/23/familias-de-criancas-mortas-por-bala-perdida-no-ricobram-respostas-e-contestam-policia-virou-rotina.ghtml>. Acessado em: ago/2020.

BALTAR, P.E.A.; SOUEN, J.A; CAMPOS, G.C.S. Emprego e distribuição da renda. In: CARNEIRO, Ricardo; BALTAR, Paulo; SARTI, Fernando. (Orgs.). Para além da política econômica. São Paulo: Editora Unesp Digital, 2018.

COLLINS, Patrica Hill. Se perdeu na tradução? Feminismo negro, interseccionalidade e política emancipatória. Tradução_Bianca Santana. Revista PARÁGRAFO. jan/jun. 2017 v.5, n.1 (2017).

CRENSHAW, Kimberlé. Documento para o encontro de especialistas em aspectos da discriminação racial relativos ao gênero, Estudos feministas 1, p.171-189, 2002.

DAVIS, Angela. Mulheres, raça e classe. 1. ed. São Paulo: Boitempo, 2016.

DWECK, Esther; OLIVEIRA, Ana Luíza Matos de; ROSSI, Pedro. (Org.). Austeridade e retrocesso: impactos sociais da política fiscal no Brasil. São Paulo: Brasil Debate e Fundação Friederich Ebert, Agosto, 2018.

G1 RIOa. Menino morre após ser baleado durante tiroteio na Baixada Fluminense. 17/03/2019. Disponível em: <https://g1.globo.com/ri/rio-dejaneiro/noticia/2019/03/17/adolescente-morre-apos-ser-baleado-no-pescoco-eabdomen-na-baixada-fluminense.ghtml >. Acessado em ago/2020.

G1 RIOb. Menino baleado na Vila Aliança, em Bangu, tem morte cerebral. G1 Rio. Disponível em: <https://g1.globo.com/ri/rio-de-janeiro/noticia/2019/05/16/meninobaleado-na-vila-alianca-em-bangu-tem-morte-cerebral.ghtml>. Acessado em: ago/2020.

GLOBONEWS. Menina de 8 anos morre baleada no Complexo do Alemão. Globo News. Disponível em:<https://g1.globo.com/ri/rio-de-janeiro/noticia/2019/09/21/meninade-8-anos-morre-baleada-no-complexo-do-alemao.ghtml>. Acessado em: ago/2020.

HOOKS, Bell. Alisando nosso cabelo. Revista Gazeta de Cuba - Unión de escritores y Artista de Cuba, janeiro-fevereiro de 2005.

DESOTI, Carolina. IDados na GloboNews: Cresce número de mulheres chefes de domicílio. IDados. Disponível em: < https://blog.idados.id/mulheres-chefes-defamilia/>. Acessado em: abr/2020.

JHONS HOPKINS UNIVERSITY. Coronavirus Resourse Center. Covid-19 Data in Motion: Monday, August 31, 2020. Disponível em: <https://coronavirus.jhu.edu/map.html>. Acessado em: Ago/2020.

MARX, Karl. O capital, livro I, volume I. São Paulo: Nova Cultural, 1988.NASCIMENTO, Tatiana. Menino de 12 anos morto durante operação da PM no Chapadão é enterrado. RJ2. Disponível em: <https://g1.globo.com/ri/rio-dejaneiro/noticia/2019/09/09/menino-de-12-anos-morto-durante-operacao-da-pm-nochapadao-e-enterrado.ghtml>. Acessado em: ago/2020. 
NASSIF-PIRES, Luiza; CARVALHO, Laura; RAWET, Eduardo. Multidimensional inequality and Covid-19 in Brazil. Public Policy Brief. Levy Economics Institute of Bard College. No. 153, 2020. ISSN 1063-5297.

NÚCLEO DE OPERAÇÕES E INTELIGÊNCIA EM SAÚDE (NOIS). Diferenças sociais: pretos e pardos morrem mais de COVID-19 do que brancos, segundo NT11 do NOIS. CTC PUC Rio, 27/05/2020. Disponível em: <http://www.ctc.puc-rio.br/diferencas-sociaisconfirmam-que-pretos-e-pardos-morrem-mais-de-covid-19-do-que-brancos-segundont11-do-nois/>. Acessado em: jun/2020.

ONU BRASIL. COVID-19: ameaças aos direitos das mulheres prejudicam a todos. ONU BRASIL. Disponível em: <https://nacoesunidas.org/artigo-covid-19-ameacas-aosdireitos-das-mulheres-prejudicam-a-todos/>. Acessado em: set/2020.

ONU MULHERES BRASIL. Trabalhadoras domésticas fazem campanha por direitos durante a pandemia Covid-19 e articulam apoio da cooperação internacional. ONU Mulheres Brasil, 2020. Disponível em: < http://www.onumulheres.org.br/noticias/trabalhadoras-domesticas-fazem-campanhapor-direitos-durante-a-pandemia-covid-19-e-articulam-apoio-da-cooperacaointernacional/>. Acessado em: jul/2020.

PEIXOTO, Ari. Criança morre baleada na Zona Norte e moradores acusam policiais de serem os autores de disparo. TV Globo, 2019. Disponível em:<https://g1.globo.com/ri/rio-de-janeiro/noticia/2019/02/14/crianca-morrebaleada-na-zona-norte-e-moradores-bloqueiam-o-transito-em-protesto.ghtml $>$. Acessado em: ago/2020.

PIKETTY, Thomas. Capital e ideologia. Trad. BRUCHARD, Dorothée; COUTO, Maria F.O. Rio de Janeiro: Editora Intrínseca, 2020.

PIKETTY, Thomas. É hora de distribuir melhor a riqueza, diz Piketty em novo livro. [entrevista concedida ao Financial Times], publicada no Valor Econômico, 2019).Disponível em: < https://www.youtube.com/watch?v=d3XF9VrzQyA>. Acessado em jan/2020.

PINHEIRO, Luana; TOKARSKI, Carolina; VASCONCELOS, Marcia. Vulnerabilidades das trabalhadoras domésticas no contexto da pandemia de Covid-19 no Brasil. Disoc -Diretoria de Estudos e Políticas Sociais, 2020.

SALVADOR, Soledad; COSSANI, Patricia. Trabalhadoras remuneradas do lar na América Latina e no Caribe frente à crise do Covid-19. Escritório Regional para a América Latina e o Caribe da ONU Mulheres. BRIEF v 1.1. 12.06.2020. Disponível em: $<$ https://www.cepal.org/sites/default/files/document/files/pttrabajadoras del hogar portugues-.pdf>. Acessado em: ago/2020.

SOF. Sem parar: o trabalho e a vida das mulheres na pandemia. Sempre Viva Organização Feminista, 2020. Disponível em: < http://mulheresnapandemia.sof.org.br/>. Acessado em: ago/2020. 
SOUZA, Jessé. A elite do atraso: da escravidão à Lava Jato. Rio de Janeiro: Leya, 2017. Disponível em: $<$ https://edisciplinas.usp.br/pluginfile.php/4411236/mod resource/content/0/Jess\%C 3\%A9-Souza-A-Elite-do-Atraso.pdf>. Acessado em: jul/2020.

WEBER, Max. Economia e sociedade: fundamentos da sociologia compreensiva. Editora Universidade de Brasília: São Paulo: Imprensa Oficial do Estado de São Paulo, 1999. 


\section{CONTESTANDOAS}

\section{ZAMPLLA}

\section{FRONTEIRASDE}

GÊNERO, RAÇAE

SEXUALIDADENA

SOCIEDADEBRASILEIRA

\section{ORGANIIZADORES}

Fabrício de Sousa Sampaio Leonardo Pereira Tavares

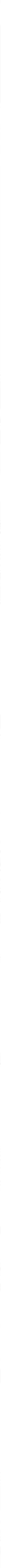




\section{Froroen \\ IAMPLLA}

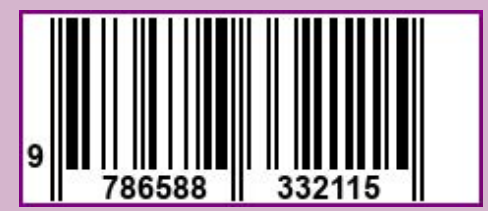

